\title{
WestVirginiaUniversity
}

THE RESEARCH REPOSITORY @ WVU

Graduate Theses, Dissertations, and Problem Reports

2006

\section{Honor, patriarchy, and disunion: Masculinity and the coming of the American Civil War}

Kenneth A. Deitreich

West Virginia University

Follow this and additional works at: https://researchrepository.wvu.edu/etd

\section{Recommended Citation}

Deitreich, Kenneth A., "Honor, patriarchy, and disunion: Masculinity and the coming of the American Civil War" (2006). Graduate Theses, Dissertations, and Problem Reports. 4224.

https://researchrepository.wvu.edu/etd/4224

This Dissertation is protected by copyright and/or related rights. It has been brought to you by the The Research Repository @ WVU with permission from the rights-holder(s). You are free to use this Dissertation in any way that is permitted by the copyright and related rights legislation that applies to your use. For other uses you must obtain permission from the rights-holder(s) directly, unless additional rights are indicated by a Creative Commons license in the record and/ or on the work itself. This Dissertation has been accepted for inclusion in WVU Graduate Theses, Dissertations, and Problem Reports collection by an authorized administrator of The Research Repository @ WVU.

For more information, please contact researchrepository@mail.wvu.edu. 
Honor, Patriarchy, and Disunion: Masculinity and the Coming of the American Civil War

Kenneth A. Deitreich

A Dissertation submitted to the Faculty of the Eberly College of Arts and Sciences

In partial fulfillment of the requirements

for the degree of

\author{
Doctor of Philosophy \\ in \\ History
}

Kenneth A. Fones-Wolf, Ph.D., Chair

Elizabeth A. Fones-Wolf, Ph.D.

Ronald L. Lewis, Ph.D.

Mary Lou Lustig, Ph.D.

Timothy Sweet, Ph.D.

Department of History

Morgantown, West Virginia 2006 


\section{ABSTRACT \\ Honor, Patriarchy, and Disunion: Masculinity \\ and the Coming of the American Civil War}

Kenneth A. Deitreich

The dissertation explores the nature of antebellum masculinity and its role in bringing on the American Civil War. It focuses its attention on two crucial episodes of the sectional crisis: the attack on Senator Sumner and the Secession Crisis of 1861 and on the four individuals, Preston Brooks, Charles Sumner, Jefferson Davis and Abraham Lincoln, who played prominent roles in those episodes.

Among the issues it explores are the degree to which Northern and Southern ideas of manhood differed and the degree to which Northerners and Southerners associated manhood with sectional identity. Did Southerners associate being a man with being a Southerner and did Northerners associate being a man with being a Northerner? Did Northerners and Southerners view themselves as more manly than their counterparts? What did people expect from their political leaders and how were those expectations shaped by masculinity? Finally to what degree did political leaders embrace antebellum ideas of masculinity, what influences were they exposed to and how did those influences shape their ideas of masculinity?

The biographical profiles illustrate how theoretical notions of masculinity were translated into the experiences of real people. As successful politicians chosen by an exclusively white male electorate, it is reasonable to assume that these individuals were keenly aware of antebellum ideas of masculinity. If nothing else they would have had to at least cater to such ideas to maintain their position.

In so doing it demonstrates that $19^{\text {th }}$ century gender roles, and especially $19^{\text {th }}$ century ideas of manhood, played a direct and contributive role in bringing on the sectional crisis and made it inevitable that secession would lead to war. Given the volatile and violent nature of $19^{\text {th }}$ century masculinity, especially that of southerners with its emphasis on honor, violence, and militarism, violent confrontation was not only justified but desirable. In view of such attitudes, war was virtually unavoidable. 
CONTENTS:

CHAPTERS:

1. INTRODUCTION . . . . . . . . . . . . . . . . . . . . 1

2. ANTEBELLUM MASCULINITY . . . . . . . . . . . . . . . . 25

PART I: THE SUMNER-BROOKS AFFAIR

3. PRESTON BROOKS . . . . . . . . . . . . . . . . . . . . . 77

4. CHARLES SUMNER . . . . . . . . . . . . . . . . . . . 102

5. THE CANING OF SUMNER . . . . . . . . . . . . . . . . 126

PART II: THE OUTBREAK OF WAR:

6. JEFFERSON DAVIS . . . . . . . . . . . . . . . . . 168

7. ABRAHAM LINCOLN . . . . . . . . . . . . . . . . . . . . 193

8. THE SUMTER CRISIS: . . . . . . . . . . . . . . . . . . 221

9. CONCLUSIONS . . . . . . . . . . . . . . . . . . . 262

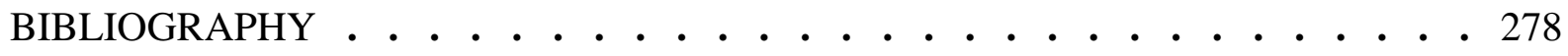




\section{CHAPTER 1}

\section{INTRODUCTION}

\section{On May 2, 1960, David Herbert Donald, Professor of American History at Oxford} University, delivered a lecture before that institution entitled "An Excess of Democracy: The American Civil War and the Social Process." In his lecture Donald took strong issue with the then dominant schools of Civil War causation. Donald divided his subject into two basic categories: the "Fundamentalists" such as James Ford Rhodes, Allan Nevins, Frederick Jackson Turner, and Charles A. Beard who emphasized issues like Southern nationalism, slavery, race adjustment, and "social and economic cleavages," and the "Revisionists" who included Avery Craven and James G. Randall, who argued that such “'causes' have no demonstrated connexion(sic) with the course of events in the 1850s," but who instead emphasized "the importance of accident, of personality, and of propaganda in shaping history."1

In Donald's view neither interpretation was satisfactory. "The 'Fundamentalists' have failed to prove that their underlying 'causes' produced the actual outbreak of hostilities." Furthermore their explanations "rely upon stereotypes which have little relation to the complex social reality of the United States in the 1850's." But at the same time Revisionists' arguments "that apparently random developments-such as the Kansas-Nebraska Bill or John Brown's Raid-produced the war" seemed to Donald equally improbable.

Do we not have to inquire why public opinion, North and South, grew so sensitive over what appears to be an abstract and unimportant point (as the spread of slavery into the territories)? And if we agree that the 1850's saw a failure of American statesmanship, do we not have to seek why this disaster afflicted the United States at this particular time and in this peculiar manner? ${ }^{2}$

\footnotetext{
${ }^{1}$ David Herbert Donald, An Excess of Democracy: The American Civil War and the Social Process. An Inaugural Lecture Delivered Before the University of Oxford on 2 May 1960, (Oxford: The Clarendon Press, 1960) $4,6 \& 8$.

${ }^{2}$ Ibid., 6-7.
} 
The Civil War rather than being the result of accident or "conflicting sectional interests" resulted from the influence "of social processes which affected the entire United States during the first half of the nineteenth century" or what Donald called "an excess of Democracy." In other words the democratic impulses unleashed during the Jeffersonian and Jacksonian eras had made the electoral system so responsive to the popular will that it had allowed marginal issues such as abolitionism and states' rights to exert a disproportional influence on the political process. $^{3}$

While it must be admitted that Donald was quite perceptive in pointing out the failings of these then-contemporary schools of thought, still it seems that his concept of "An Excess of Democracy" does not quite reach the mark of explaining the war. In attempting to understand what caused the Civil War it is necessary to ask two fundamental questions: why did the South secede and why did secession lead to war? Cultural dissonance, economic grievances, antislavery agitation and states' rights may explain the South's decision to secede but they cannot tell us why that decision led to war. Clearly something more was at work. As Donald himself phrased it: "If Jefferson Davis's government had refused to fight for independence, there could, of course, have been no war. Similarly, if Lincoln's administration had acquiesced in the peaceful secession of the South, there would have been no conflict." ${ }^{4}$ If we are to understand why Davis chose to fight and why Lincoln chose not to "acquiesce" it is not enough to merely

\footnotetext{
${ }^{3}$ Ibid., 8, 9, 10, 11, 12, 16, \& 28..

${ }^{4}$ Ibid., 5-6.
} 
speak of "the influence of social forces on the government." It is necessary to understand the nature of those social forces. ${ }^{5}$

This dissertation represents an attempt to better understand those social forces that played such a crucial role in bringing on the Civil War. It seeks to do this through an examination of the ways in which $19^{\text {th }}$ century masculinity contributed to the coming of the Civil War. In so doing it will attempt to answer two questions: what was antebellum masculinity and what role did it play in bringing on the war. It will focus its attention on the years 1848-1861, the period during which the North-South rivalry degenerated from a political debate into a series of increasingly violent episodes. $^{6}$

The dissertation begins, in Chapter Two, with an in-depth examination of the concept of antebellum masculinity, which it will define in a theoretical sense and trace its origins and development during the years preceding the Civil War. Subsequent chapters will explore the role of masculinity in bringing on the Civil War through an examination of two key incidents of the antebellum period: the Caning of Sumner and the Sumter Crisis of 1861 and the four individuals who played key roles in those incidents and who also represented significant geographic regions and socio-economic groups--Preston Brooks, Charles Sumner, Jefferson Davis, and Abraham Lincoln. A series of biographical profiles of these men will demonstrate both how theoretical concepts of masculinity were translated into the daily lives of individuals and how masculinity helped shape the character and actions of four individuals who were the main participants in two key incidents which helped to bring on the Civil War.

\footnotetext{
${ }^{5}$ Ibid.; see also, The Causes of the Civil War, Kenneth M. Stampp ed., (Englewood Hills, N.J.: PrenticeHall, Inc, 1959).

${ }^{6}$ David M. Potter, The Impending Crisis: 1848-1861 Completed and Edited by Don E. Fehrenbacher, (New York: Harper \& Row, 1976) 6, 16-17.
} 
It is not my contention that Brooks, Sumner, Davis and Lincoln comprise anything like a representative sampling of $19^{\text {th }}$ century American society. On the contrary they are decidedly unrepresentative, being composed entirely of white Protestants. They include no blacks, gays, Roman Catholics, Jews, immigrants, Native Americans and most glaringly of all no women. Furthermore to one degree or another they are all members of the political and social elite; with the possible exception of Lincoln, none of them can be said to represent even the middle class, let alone the poor or working classes. Despite these limitations, as a means for examining antebellum notions of manhood these individuals are not entirely without merit. To begin with, the mere fact that Sumner, Brooks, Lincoln, and Davis were members of the political elite does not necessarily make them unreflective of nineteenth century American males.

Of these four individuals, Preston Brooks was the least prominent. The "Caning Incident" was Brooks's only moment in the spotlight, aside from his service in the Mexican War. While Brooks was well-liked by his colleagues in Congress, he was regarded as a man of moderate views and moderate ability. Sadly if Brooks thought that the attack would give a boost to his career he was disappointed. Despite admirers sending him canes to replace the one he broke over Sumner's head, Brooks returned to obscurity and in fact did not even live to see the "Southern Revolution" that he had helped to inspire.

The choice of Charles Sumner is perhaps the easiest to understand. As David Donald wrote in his celebrated biography of Sumner:

Sumner's life touched upon virtually every significant movement in mid-nineteenth century American history. He was an advocate of international peace; leader of educational and prison reform movements; organizer of the antislavery Whigs; a founder of the Republican party; the outstanding antislavery spokesman in the Senate during the 1850s; chief of the Radical Republicans during the Civil War; chairman of the Senate Committee on Foreign Relations during both the war and the Reconstruction years ... 
Charles Sumner was one of the most potent and enduring forces in the American government. $^{7}$

Beyond that Sumner occupied a unique place in American history, being one of the few successful examples of a "statesman doctrinaire", a politician "inflexibly committed to a set of basic ideas as moral principles." Furthermore there is much that can be learned from Sumner concerning the state of American intellectual thought at the time. Sumner, perhaps alone among nineteenth-century American intellectuals, enjoyed an international reputation as a scholar and counted among his friends such luminaries as Ralph Waldo Emerson and Pierre Soule. Similarly Sumner was perhaps the only American politician of his age to achieve international fame and was acquainted with "practically every important political leader and literary figure in England, France, Germany, and Italy."8

Jefferson Davis was half of the political equation that led North and South to War. But Davis, unlike Lincoln, was a prominent politician before the war, having served as both a United States Senator and as Secretary of War under President Franklin Pierce. Added to that was the fact that Davis was a West Point graduate who served with distinction in the Mexican War, both in keeping with the Southern warrior tradition. As Secretary of War Davis had helped to engineer the Gadsden Purchase and had been a vocal advocate of the annexation of Cuba, both of which raised the hackles of many Northerners who saw them as evidence of a "Slave Power" conspiracy plotting to expand slavery territory. During his Senate career Davis, like Lincoln, was seen as a moderate. He was a staunch defender of states' rights but resisted secession right until the end. Davis's election as president symbolized a shift in the balance of power in Southern

\footnotetext{
${ }^{7}$ Donald, $\underline{\text { Sumner, vii. }}$

${ }^{8}$ Donald, Sumner, vii-viii.
} 
politics from the Tidewater aristocrats to the Southwest. Davis represented the "new" generation of planters in the Southwest who seized control of southern political leadership from coastal aristocrats in Carolinas and Virginia.

Given Davis's status as a member of the planter elite, his formal (almost regal) bearing and his reputation as a political moderate, it was no wonder that he was elected president of the Confederacy. However given the fact that he hailed from the Mississippi valley rather than the coastal regions of Virginia or the Carolinas Davis would have been exposed to a different version of "Southern Chivalry." Davis absorbed Southern concepts of gentility and "chivalry" but interpreted those concepts differently than his eastern counterparts. One final point that should be mentioned is the fact that both Lincoln and Davis were natives of Kentucky which only serves to expand the basis for comparison between the two men.

Besides the fact that together with Davis, Abraham Lincoln comprised the political leadership of North and South during the secession crisis there are other reasons for including Lincoln. As a young man in Illinois he served honorably, if less than brilliantly, in the Black Hawk War. From an early age Lincoln took an active interest in Illinois state politics and together with eight other members of the Whig party successfully campaigned in 1837 to move the state capital from Vandalia to Springfield. As a Whig congressman Lincoln had been a vocal critic of the U.S.-Mexican War. His decision not to seek reelection led to a temporary retirement from political life broken by his opposition to the Kansas-Nebraska Act and becoming an organizer of the Republican party in Illinois. His debates with Stephen Douglas during the U.S. Senate Campaign of 1858 served as a sounding board for many of the issues separating North 
and South, especially Popular Sovereignty. More importantly, they established Lincoln as a national political figure.

Lincoln, alone among these individuals, grew up poor. His rise from complete obscurity to professional and political prominence embodied to a considerable degree the Free Soil ideal of the self-made man. Having grown up on the frontier and experienced the struggle for survival that it entailed, Lincoln was exposed from an early age to the rough-and-tumble image of manhood associated with the frontier. Furthermore, the Old Northwest, and especially Lincoln's home state of Illinois, played a crucial role in the formation of the Free Soil movement and the Republican party. His election as president symbolized a shift in the political balance of power from the South and East toward the frontier Northwest. Last, and perhaps most importantly, is the fact that Lincoln's election as president was the immediate precursor to secession. The question naturally arises: what was it about this moderate that so alarmed Southerners that they no longer felt safe in the Union with him as president?

If not representative the group was at least broad-based; from a geographic standpoint it includes two northerners (Lincoln and Sumner); two southerners (Davis and Brooks); two easterners (Sumner and Brooks); and two westerners (Davis and Lincoln). Furthermore, as successful politicians chosen by an exclusively white male electorate, it is reasonable to assume that these men would have not only been aware of antebellum ideas of masculinity but also that they would have had to at least acknowledge such notions in order to maintain their position. ${ }^{9}$ As Nicole Etcheson has written: "Whether it meant proving one's manhood in a battle, wrestling

\footnotetext{
${ }^{9}$ For more on political leaders as symbols of "the manliness ethos" of antebellum males see David G. Pugh, Sons of Liberty: The Masculine Mind in Nineteenth Century America (Westport, Conn.: Greenwood Press, 1983).
} 
match, or fist fight, southern settlers wanted men for candidates--not namby-pamby runts."10

Certainly Northern voters were no less likely to support candidates who reflected those values.

Finally, and perhaps most importantly, they were the main actors in two of the most crucial episodes of the sectional crisis: the "Caning of Sumner" and the "Sumter Crisis of 1861." These episodes were not only turning points in the sectional crisis but were also highly evocative of $19^{\text {th }}$ century attitudes toward manhood.

This dissertation is divided into two sections. Part one deals with the first episode, the so-called "Caning of Sumner," and the two participants in that incident, Preston Brooks and Charles Sumner. The "Caning of Sumner" was one of the most notorious incidents of the nineteenth century, one that inflamed passions in both North and South and played a critical role in bringing on the war. The attack was both inspired by, and symbolic of, the violence then raging in "Bleeding Kansas," and reflected the increasingly violent nature of sectional politics. It marked the first time that a politician resorted to violence, rather than words, to defend his section's interests. $^{11}$

In part two the focus is on "The Sumter Crisis of 1861" and Presidents Davis and Lincoln. It refers specifically to the period between the secession of the Lower South and the attack on Fort Sumter (December 20, 1860-April 12, 1861). The Sumter Crisis marks the focal point of the entire sectional crisis, the moment when the forces driving North and South apart finally drove them to war. If we are to come to grips with the causes of the Civil War, it only

\footnotetext{
${ }^{10}$ Nicole Etcheson, "Manliness and the Political Culture of the Old Northwest, 1790-1860", Journal of the Early Republic Vol 15, (Spring, 1995) 64, 68 \& 70..

${ }^{11}$ Baldasar Castiglione, The Book of the Courtier ed. and trans. By George Bull (London: Penguin Books Ltd, 1967, 117-18; Bertram Wyatt-Brown, Southern Honor: Ethics and Behavior in the Old South (Oxford: Oxford University Press, 1982) 166-7.
} 
makes sense to focus attention on the actual outbreak of hostilities and the social dynamic of that process. This becomes even clearer when one considers the fact that sizable elements of the population in both sections envisioned secession as a peaceful, even legal, process. Why then did it lead to war?

\section{-Objectives-}

In examining the relationship between masculinity and the coming of the Civil War this dissertation will attempt to determine what antebellum masculinity was and what impact it had upon the sectional crisis. Chapter Two will provide a theoretical and practical definition of masculinity. Among the questions it addresses are: what was antebellum masculinity; where did it come from; and how did it translate into the lives of real people. It will formulate an objective definition of "masculinity": what it meant to be "masculine," how men were expected to act, what was expected of them in terms of attitudes, values, conduct, and language. It will examine the development of antebellum masculinity: its origins in European culture and the influence of the American experience in shaping antebellum concepts of masculinity.

The biographical profiles will demonstrate how theoretical notions of masculinity were translated into the experiences of real people, through such activities as religion, sports, economics, morality, and virtue. By examining the backgrounds and experiences of Sumner, Brooks, Lincoln and Davis, the reader will gain not only an increased sense of their individual characters but also of the external forces that shaped those characters: what values and attitudes were instilled in them by parents, church, school, and their peers.

By examining two key episodes of the antebellum crisis (the "Caning of Sumner" and the Sumter Crisis), and building upon the concepts developed in Chapter Two, this work will show 
how antebellum masculinity affected the sectional crisis. Among the questions it will address: how did antebellum masculinity affect the political process; how did it influence elected officials; what did people expect from their political leaders and how were those expectations shaped by masculinity? To what degree did political leaders embrace antebellum concepts of masculinity and what influence did those concepts exert upon the decision-making process of the political leadership, specifically Presidents Lincoln and Davis.

Likewise this dissertation will examine how closely gender identity was associated with sectional identity and economic systems. To what degree did Northern and Southern ideas of manhood differ, and how closely did Northerners and Southerners associate manhood with sectional identity? Did Northerners and Southerners view themselves as being more manly than their counterparts? Moreover, what was the relationship between masculinity and economics? How did the North's market economy and the South's slave economy affect masculinity? Did Northern businessmen view masculinity differently from workingmen? Did southern planters view masculinity differently from yeoman farmers and poor whites? How did masculinity relate to matters of race? How did slavery affect southern ideas of manhood, and how did both slavery and masculinity affect antebellum attitudes toward women of both races?

By looking at policy statements, speeches, letters, and newspaper accounts, it is my intention to show how the actions and attitudes of Lincoln and Davis were both influenced by, and a reflection of, $19^{\text {th }}$ century masculinity. It will demonstrate that $19^{\text {th }}$ century concepts of masculinity and manhood were the key factors that ensured that secession would result in war.

It is important to point out that I do not contend that masculinity caused the Civil War. To do so would be a gross misrepresentation of the facts. I merely contend that $19^{\text {th }}$ century ideas of 
manhood played a direct and contributive role in bringing on the secession crisis and made it inevitable that secession would lead to war. The importance of antebellum masculinity on the decision-making process was two fold: first in the influence it exerted over the political leadership, and indirectly in the fact that all these other factors--slavery, economics, even sectionalism--were all closely associated with the concepts of masculinity. It was that influence and close association that insured that secession would result in war.

One final point on the matter of gender. In order to limit its scope, this paper shall not concern itself with female gender roles. This is in no way to denigrate, nor dismiss, the importance of women to the process. The impact of woman during the years preceding the Civil War has been well documented. But the present work shall limit itself to the discussion of male gender roles. This is an entirely logical choice given the subject matter. As Bertram WyattBrown points out in Southern Honor, in the minds of southerners militarism was closely linked to matters of manhood and self-worth. ${ }^{12}$ Furthermore, since only men could vote, this makes it all the more essential that politicians of that era would be strongly influenced by contemporary ideas of masculinity and manhood.

Nor will this study concern itself with the causes of sectionalism, the legal merits of secession, nor with justifications for the firing on Sumter. For the purposes of this study such issues are largely irrelevant except to the extent that they impacted upon the outbreak of the war. This study is concerned with showing how manhood and manliness contributed to the divisions that led to war and the role that manhood and manliness played in sparking the war's outbreak.

\footnotetext{
${ }^{12}$ Wyatt-Brown, Southern Honor, 34-36.
} 
Finally, by illustrating not only the differences in masculinity but the commonalities as well, the biographical profiles will also explore the degree to which the North and South, despite their protestations of distinctiveness, shared certain assumptions about gender and the nature of manhood. In this way it will be illustrated that these men, similarities were as important as differences in bringing on the war.

\section{-Historiographical Review-}

Traditionally Civil War historiography, has for the most part concerned itself with two fundamental questions: what caused the Civil War, and was the war avoidable? In short, was the Civil War a Repressible or an Irrepressible Conflict? ${ }^{13}$ In the years immediately following the war, Civil War historiography was less a question of discovering its causes than of assigning guilt. Bitter memories of the war turned the discussion into an exercise in self-justification. Northern partisans, blamed the war on the "Slave Power" and its efforts to expand plantation slavery beyond the confines of the Old South and force its acceptance upon the nation-at-large. This aggressive policy of slavery expansion "forced the North to defend the Union, the Constitution, and basic human rights." ${ }^{14}$ Southerners countered that the real cause lay in Northern attitudes of moral and cultural superiority, and in Northerners' efforts to establish political, economic, and cultural dominance over the South. ${ }^{15}$

\footnotetext{
${ }^{13}$ Allan Nevins, William W. Freehling, “The Civil War: Repressible or Irrepressible?” Interpretations of American History Patterns and Perspectives, Volume I: Through Reconstruction, Francis G. Couvares, Martha Saxton, Gerald N. Grob, George Billias eds., (New York: The Free Press, 2000), 339.

${ }^{14}$ Henry Wilson, History of the Rise and Fall of the Slave Power in America, 3 vols. (Boston, 1872-77) as quoted in Couvares, et. al. ; See also, Avery Craven, The Coming of the Civil War (New York: Charles Scribner's Sons, 1942); Nevins \& Freehling, 340; Kenneth M. Stampp, The Imperiled Union: Essays on the Background of the Civil War (New York, Oxford: Oxford University Press, 1980).

${ }^{15}$ Edward A. Pollard, The Lost Cause: A New Southern History of the War of the Confederates (New York: 1866); The Causes of the Civil War, Kenneth M. Stampp ed., (Englewood Hills, N.J.: Prentice-Hall, Inc, 1959 ), 173.
} 
Toward the end of the nineteenth century a less biased view of the war began to emerge although not necessarily a more objective one. Historians of this era were strongly influenced by an increasing sense of American nationalism that was closely associated with the rise of America as a major industrial power. Both of these developments were regarded by contemporary scholars as being indirect outcomes of the Civil War and as "unambiguous[ly] good." ${ }^{\text { }}$ Despite the tragic loss of life and treasure that it brought about "the Civil War had yielded an unforeseen and undeniable good: a modern, united, and powerful America." ${ }^{17}$

For Southern historians, like Woodrow Wilson, the causes of the war were less important than its results: sectional reconciliation and economic industrialization. Southern historians condemned slavery for "saddling the South with a backward economy and a hopelessly unproductive workforce." ${ }^{\text {18 }}$ It was slavery and its reliance upon staple agriculture, argued Edward Channing, that had caused the South to develop differently from the rest of the country. ${ }^{19}$

Early in the twentieth century a new historiographical school arose, called the Progressives. Progressive historians took a more jaundiced view of the Civil War, seeing in its outcomes class conflict, social dislocation, disparities in wealth, the rise of a class of ruthless

\footnotetext{
${ }^{16}$ Edward Channing, The United States of America, 1765-1865 (New York: The McMillan Company, 1896) and A History of the United States, 6 vols. (New York: The McMillan Company, 1905-25); Stampp, Imperiled Union, 194; Nevins \& Freehling, 341-3; James Ford Rhodes, Lectures on the American Civil War (New York: The McMillan Company, 1913) 2-16, 76-77; "Slavery the 'Single Cause'”, Kenneth M. Stampp, ed. The Causes of the Civil War (Englewood Cliffs, N.J.: Prentice Hall, Inc., 1965) 107-8; Imperiled Union, 193.

${ }^{17}$ Rhodes, History of the United States from the Compromise of 1850 to the Final Restoration of Home Rule in the South in 1877, 7 vols. (New York: The McMillan Company, 1893-1906) cited in Nevins \& Freehling, 342.

${ }^{18}$ Nevins \& Freehling, 342.

${ }^{19}$ Channing, The United States of America, 1765-1865, 261 and A History of The United States VI, 3-6; Stampp, Imperiled Union, 194; Nevins \& Freehling, 343.
} 
"Robber Barons" and other ill-effects of industrialism. ${ }^{20}$ The war's most severe Progressive critics were Charles and Mary Beard. To the Beards, who also saw it as "irrepressible" the Civil War was a "Second American Revolution:" one in which capitalists "drove from power in the national government the planting aristocracy of the South." ${ }^{21}$ The Southerners' loss of political power at Washington, combined with fears of "the exploitation of the South for the benefit of northern capitalism" created a belief that Southerners could only defend themselves by seceding from the Union. ${ }^{22}$

At about the same time that Progressivism was gaining wide acceptance, Marxist historians also began to take issue with Nationalist interpretations. To Marxist historians the Civil War "was indeed . . . a 'Second American Revolution'”; a struggle between Northern capitalism and Southern slavery. ${ }^{23}$ In the final analysis the Civil War "was fought that the capitalist class might rule." ${ }^{24}$ Louis M. Hacker, similarly sees the secession crisis as "a counterrevolutionary movement" among slaveholders who attempted to resist the triumph of industrial capitalism as represented in the election of Lincoln in 1860. The North's victory in the Civil

\footnotetext{
${ }^{20}$ Matthew Josephson, The Robber Barons: The Great American Capitalists 1861-1901 (New York Harcourt, Brace and Company, 1934) viii; Nevins \& Freehling, 343-4.

${ }^{21}$ Ibid.

${ }^{22}$ Charles A. and Mary R. Beard, The Rise of American Civilization, 2 vols. (New York The McMillan Company, 1927) Vol. 2: 36-47, 53-56; Charles A. and Mary R. Beard, "The Clash of Rival Economies", The Causes of the Civil War, Kenneth M. Stampp ed., (Englewood Hills, N.J.: Prentice-Hall, Inc, 1959), 56-9; Nevins \& Freehling, 343 \& 344.

${ }^{23}$ Algie M. Simons, Class Struggles in America (Chicago: C.H. Kerr, 1906) 32-36 and "The Civil War and the Class Struggle," in Causes, 60 \& 61-62; Louis M. Hacker, "Revolutionary America", Causes, 62-5; first published in Harper's Magazine (March, 1935); Stampp, The Imperiled Union, 195; James S. Allen, Reconstruction: The Battle for Democracy 1865-1876 (New York International Publishers, 1937) 18 \& 26-28; Nevins \& Freehling, 344.

${ }^{24}$ Simons, 61-2.
} 
War "had freed capitalism from the political and economic restraints upon free economic activity that the slave power had imposed." ${ }^{25}$

During the Great Depression two new schools of Civil War historiography arose that stood in sharp contrast to the Beardian and Marxist schools. The first, "Southern Agrarians," took a sympathetic, if not favorable, view of the antebellum South which they thought "superior to the urbanized and industrial condition of . . 20 $0^{\text {th }}$ century America." They also thought that the role of slavery in bringing on the war had been overemphasized. ${ }^{26}$ For these "Southern Agrarians it was the North that was to blame for the war by having destroyed "the sectional balance of power" in order to seize control of the Federal government. ${ }^{27}$

The second Depression-era school, the "Revisionists" represented a complete break with earlier approaches. Cynical toward patriotic appeals and convinced that "wars never attained the noble objectives for which they were supposedly fought," the Revisionists saw the Civil War not as a moral crusade fought over questions of economics, political philosophies, or even slavery but as an unrefined and unnecessary evil. It was the result of a failure in leadership: an inability or unwillingness among politicians to find an acceptable alternative to fighting. The political leadership of both North and South, by disregarding the "genuine political alternatives" that were available to them "bore the enormous moral burden of having sent hundreds of thousands to their

\footnotetext{
${ }^{25}$ Louis M. Hacker, "Revolutionary America", The Causes of the Civil War, Kenneth M. Stampp ed., (Englewood Hills, N.J.: Prentice-Hall, Inc, 1959), 64-65; Hacker, "Revolutionary America," Harper's Magazine (March, 1935), pp. 438-40, 441..

${ }^{26}$ Frank L. Owsley, "Fundamental Cause of the Civil War: Egocentric Sectionalism," Journal of Southern History, 7 (February 1941): 3-18, and "The Irrepressible Conflict," in Twelve Southerners: I'll Take My Stand (N.Y., 1930) pp. 77-78); Nevins \& Freehling, "The Civil War", 345-6; Stampp, Imperiled Union, 201.

${ }^{27}$ Ulrich B. Phillips, "The Central Theme of Southern History," American Historical Review, XXXIV (1928), 30-43; Owsley, “Egocentric Sectionalism,"; Nevins \& Freehling, 345-6; Causes, 171.
} 
deaths and impoverished millions. ..."28 It was the product of what James G. Randall called "A Blundering Generation.”

Let one take all the factors traditionally presented-the Sumter maneuver, the election of Lincoln, abolitionism, slavery in Kansas, prewar objections to the Union, cultural and economic differences, etc.-and it will be seen that only by a kind of false display could any of these issues, or all of them together, be said to have caused the war if one omits the elements of emotional unreason and overbold leadership. . . ${ }^{29}$

Avery Craven, in The Coming of the Civil War took the "Blundering Generation" thesis even further. Rather than being caused by sectional differences or slavery the Civil War was the result of an ignorant voting public who had "permitted their short-sighted politicians, their overzealous editors, and their pious reformers" to distort not only the facts but their images of themselves and of their sectional counterparts. ${ }^{30}$ In so doing "They turned the normal American conflict between agriculture and industry, farmers and planters, section and section, into a struggle of civilizations." And thus when economic competition was turned into an issue of good versus evil "Good men had no choice but to kill and to be killed." Thus was a repressible conflict made into "an irrepressible one." 31

Such views came under sharp criticism following World War Two from historians who condemned the Revisionists for their perceived amoral stance on slavery and other issues. Strongly influenced by the horrors they witnessed during the war and especially the Holocaust, scholars like Roy F. Nichols, Pieter Geyl, and Samuel Eliot Morrison argued that while all wars

${ }^{28}$ J.G. Randall, "The Blundering Generation,” Mississippi Valley Historical Review, 27 (June 1940): 4-16 and Causes, Stamp ed. , 83; Stampp, Imperiled Union, 199, 205; Nevins \& Freehling, 344-7.

${ }^{29}$ Randall, "Blundering Generation", 36-47 \& 84-6; Stampp, ed. The Causes of the Civil War, 82-5; Stamp, The Imperiled Union, 205.

${ }^{30}$ Avery Craven, The Irrepressible Conflict 1830-1861 (Baton Rouge, La., 1939), 64 and The Coming of the Civil War (New York: Charles Scribner's Sons, 1942),vii \& 1-2; Stampp, Imperiled Union, 199 \& 205; Nevins \& Freehling, 346.

${ }^{31}$ Craven, Irrepressible Conflict: 1830-1861, 15-6, 64 and Coming of the Civil War, 2; J.G. Randall, "Blundering Generation", 4-16. 
might be inherently evil, there were times when nations, like individuals, were justified in choosing war as the lesser of two evils. ${ }^{32}$ The most vocal of these post-war critics was Arthur M. Schlesinger, Jr. Schlesinger severely chastised the revisionists for both their cynicism and lack of moral clarity. ${ }^{33}$ Not only did Revisionists ignore the morality of the slavery issue but they failed to answer an even more basic question: "If the war could have been avoided, what course should American leaders have followed?"34

According to Schlesinger, there were only three alternatives, none of which were feasible: "that the South might have abolished slavery by itself if left alone; that slavery would have died because it was economically unsound; or that the North might have offered some form of emancipation compensation." In the end, Schlesinger's view was that the Revisionists were "unrealistic to think that a moral issue as complex as slavery could be solved by any means other than force."35

Kenneth M. Stampp, in his 1965 work, The Causes of the Civil War, tried to take a more comprehensive approach to the question. Stampp reasoned that the question of what caused the Civil War was really three distinct, yet interrelated questions:

(1) What caused the North and South to engage in ceaseless controversy for more than a generation? (2) What caused the states of the Deep South to secede after Lincoln's

\footnotetext{
${ }^{32}$ Roy F. Nichols, The Disruption of American Democracy (N.Y.: The McMillan Company, 1948); Kenneth M. Stampp, And the War Came: The North and the Secession Crisis, 1860-1861, (Baton Rouge, La: Louisiana State University Press, , 1950); Samuel Eliot Morison, "Faith of a Historian,” American Historical Review, 56 (January 1951): 267; Bernard DeVoto, “The Easy Chair,” Harper's Magazine (February, 1946), pp. 123-26; Causes, 110, 118; Pieter Geyl, "The American Civil War and the Problem of Inevitability,” New England Quarterly, XXIV (1951), 147-68; Causes, 118; Nevins \& Freehling, 347-8.

${ }^{33}$ Arthur M. Schlesinger, Jr., "The State Rights Fetish," New Viewpoints in American History, (New York: The McMillan Company, 1922), 22-43; "The State Rights Fetish," in The Causes of the Civil War, Kenneth M. Stampp ed., (Englewood Hills, N.J.: Prentice-Hall, Inc, 1959), 41-5.

${ }^{34}$ Schlesinger, "The Causes of the Civil War: A Note on Historical Sentimentalism," Partisan Review, XVI (October 1949); 969-981. Freehling, 348 .

${ }^{35}$ Schlesinger, "Causes," 969-81; "The Inevitability of Violence”, Causes, Stampp, ed., 114; Nevins \&
} 
election in 1860? (3) What caused the great majority of Northerners to prefer war to the recognition of Southern independence? ${ }^{36}$

Having made such a promising start, Stampp then identifies seven basic and broad categories of factors which help account for the North-South conflict. They include: the "Slave Power" and the "Black Republicans"; State Rights and Nationalism; Economic Sectionalism; Blundering Politicians and Irresponsible Agitators; the Right and Wrong of Slavery; Majority Rule and Minority Rights; and the Conflict of Cultures. ${ }^{37}$ In the end however, Stampp's analysis also fails. None of these factors, facile as they are in describing the divisions between North and South, can adequately answer his third question. Stampp is finally forced to conclude that "As one reflects upon the problem of causation it becomes perfectly evident that historians will never know objectively and with mathematical precision what caused the Civil War."38

Since the early 1960s new developments in technology, most notably computers, have inspired yet another generation of historians to question not only traditional Civil War historiography but the very relevance of the Civil War itself, including slavery. Unlike traditional approaches that emphasized "major issues" such as slavery, and major figures such as political and military leaders, these "political historians" emphasized "the social basis of politics and employed quantitative techniques." ${ }^{39}$ For scholars such as Joel H. Silbey and Michael F. Holt, issues like slavery were of less importance to the average voter than "ethnocultural" conflicts such as: native v. immigrant, Protestant v. Catholic, and "proponents and opponents of

\footnotetext{
${ }^{36}$ Kenneth M. Stampp, ed. The Causes of the Civil War (Englewood Cliffs, N.J.: Prentice Hall, Inc., 1965)

${ }^{37}$ Ibid., Introduction, v, 3, 5, 37, 59, 81, 108, 153, 166; and Stampp, The Imperiled Union.

${ }^{38}$ Ibid.

${ }^{39}$ Nevins \& Freehling, 348-9.
}

3. 
Temperance." ${ }^{40}$ According to Holt, the inability of "the normal political process" to adequately deal with that threat led Americans to abandon the Whig party first for the Know-Nothings and later for the Republicans. The resulting breakdown of the Second Party System, combined with the South's refusal "to accept the decision of a presidential election" led directly to war. ${ }^{41}$

Eric Foner, in Free Soil, Free Labor, Free Men, attempted a reconciliation between slavery, which he viewed as the underlying cause of the Civil War, and socio-cultural factors through the concept of "Free Labor." According to Foner, "Free Labor" ideology, with its emphasis on social mobility and individualism was the glue that held the fragile Republican coalition together. Whatever else Republicans might disagree on, and they disagreed on just about everything, they were all determined that slavery not be allowed to expand into the Western territories. To do so "would threaten the very survival of the American experiment in constitutional republicanism. ${ }^{42}$ The election in 1860 of a president dedicated to just such a policy of blocking slavery's expansion led to "a polarization of American politics" along ideological lines and ultimately to war. ${ }^{43}$

The 1970s also saw the publication of one of the seminal works in the field, David Potter's The Impending Crisis. A book of herculean scope (indeed Potter did not live to complete it), Crisis took a more sophisticated view of the questions of cause and inevitability.

\footnotetext{
${ }^{40}$ Ibid. Eric Foner, "The Causes of the American Civil War: Recent Interpretations and New Directions, Civil War History, 20 (September 1974): 194-214; Joel H. Silbey, The Partisan Imperative: The Dynamics of American Politics Before the Civil War (New York: Oxford University Press, 1985), also The Shrine of Party: Congressional Voting Behavior, 1841-1852 (Pittsburgh: University of Pittsburgh Press, 1967).

${ }^{41}$ Michael F. Holt, The Political Crisis of the 1850s, (New York: W.W. Norton \& Company, 1978) 1, and "An Elusive Synthesis: Northern Politics During the Civil War," in James McPherson and William J. Cooper, eds. Writing the Civil War: The Quest to Understand (Columbia, S.C.: University of South Carolina Press, 1998), 12234; Stampp, Imperiled Union, 209; Nevins \& Freehling, 349.

${ }^{42}$ Eric Foner, Free Soil, Free Labor, Free Men, The Ideology of the Republican Party Before the Civil War, (Oxford: Oxford University Press, 1970) 4, 9-10; see also: William L. Barney, The Road to Secession: A New Perspective on the Old South (New York, 1972); Nevins \& Freehling, 350-1.

${ }^{43}$ Ibid.
} 
Concentrating his attention on the years between the end of the Mexican War and 1860, Potter argued that victory in the Mexican war and the territorial gains that it brought disturbed the sectional balance of power. By choosing to take on this empire in the West, American leaders had "sealed the triumph of national expansion, but it had also triggered the release of forces of sectional dissension., ${ }^{44}$ Thus, by an act of free will they had made the war inevitable. In other words the war was both repressible and irrepressible. ${ }^{45}$

No account of Civil War historiography would be complete without at least mentioning James McPherson's Battle Cry of Freedom (1988). Rejecting a revisionist approach, McPherson attributed the war largely to a strong desire among southerners to fight for what they considered to be their "rights and liberties" including: ${ }^{46}$

The right to own slaves, the liberty to take this property into the territories: freedom from the coercive powers of a centralized government. Black Republican rule in Washington threatened republican freedoms as the South understood them. The ideology for which the fathers had fought in 1776 posited an eternal struggle between liberty and power." ${ }^{\prime 47}$

In other words, Southerners' loss of control over the federal government to a party that was determined to end slavery represented a mortal threat to their way of life. Faced with such a calamitous set of circumstances Southerners concluded that "the South could protect its liberty from the assaults of hostile power only by going out of the Union." ${ }^{48}$

Richard Sewell has also been at the forefront both in rejecting revisionist interpretations and in returning slavery to the center of the debate over Civil War historiography. Both McPherson and Sewell, and many of their colleagues, have pursued an integration between

\footnotetext{
${ }^{44}$ David M. Potter, The Impending Crisis, 1848-1861 (completed and edited by Don E. Fehrenbacher) (New York: Harper \& Row, 1976) 6, 16-17.

${ }^{45}$ Ibid.

${ }^{46}$ James McPherson, Battle Cry of Freedom: The Civil War Era, (New York: Ballantine Books, 1988) 241.

${ }^{47}$ Ibid., 241.

${ }^{48}$ Ibid.
} 
Nationalist and Progressive approaches. Like Nationalists they viewed the war as "tragic but morally unavoidable," but like Progressives they also acknowledged the influence of the NorthSouth economic rivalry, along with "social, cultural, and ideological differences."49

Another recent development of the past decade has been social history, which deals with the daily concerns of ordinary people and with groups previously overlooked by traditional historians: especially blacks and women. ${ }^{50}$ If the roles of blacks were underappreciated by traditional historians, those of women were blatantly ignored. To the degree that women were studied it was usually within the context of such "auxiliary" and gender segregated capacities as nursing, fund-raising, morale building and the like. But as Mark C. Carnes and Clyde Griffin note in their introduction to Meanings for Manhood, women's historians in recent years have "unearthed new sources, spawned entirely new fields of inquiry, and greatly expanded the theoretical underpinnings of the entire discipline of history." ${ }^{\text {} 51}$

At the same time, scholars such as Peter Stearns and Edward Shorter have also begun to reexamine men's history as well. ${ }^{52}$ In fact women, including Gerda Lerner, have been among the

\footnotetext{
${ }^{49}$ Richard H. Sewell, A House Divided: Sectionalism and the Civil War 1848-1865 (Baltimore: Johns Hopkins University Press, 1988) McPherson, Battle Cry and, Ordeal by Fire).

${ }^{50}$ Maris A. Vinovkis, ed., Toward a Social History of the American Civil War: Exploratory Essays (Cambridge: Cambridge University Press,, 1990); Drew Gilpin Faust, “'Ours as Well as That of the Men': Women and Gender in the Civil War," in McPherson and Cooper, Writing the Civil War, pp. 228-240.); Thomas J. Pressly, Americans Interpret Their Civil War (Princeton: Princeton University Press, 1954) pp. 321-24 Nevins \& Freehling, 354-5.

${ }^{51}$ Introduction, Meanings for Manhood: Constructions of Masculinity in Victorian America, Mark C. Carnes and Clyde Griffen ed., (Chicago: University of Chicago Press, 1990), 1.

${ }^{52}$ Edward Shorter, "Illegitimacy, Sexual Revolution, and Social Change in Modern Europe," Journal of Interdisciplinary History II (1971): 251-253; idem, The Making of the Modern Family (New York: Basic Books, 1975); Peter N. Stearns, Be A Man! Males in Modern Society (New York: Holmes \& Meier Publishers, Inc., 1979), 1-5, 9; G.J. Barker-Benfield, The Horrors of the Half-Known Life: Male Attitudes toward Women and Sexuality in Nineteenth-Century America (New York: Harper and Row, 1976) and Christine Stansell, City of Women: Sex and Class in New York: 1789-1860 (New York: Knopf, 1986,), as cited in Introduction, Carnes and Griffen ed., 2-3; Mary Beth Norton Founding Mothers and Fathers: Gendered Power and the Forming of American Society (New York: A. A. Knopf, 1996). see also Steven Goldberg, The Inevitability of Patriarchy (New York: Morrow, 1973); see also David G. Pugh, Sons of Liberty: The Masculine Mind in Nineteenth-Century America (Westport, Conn.: Greenwood Press, 1983); Joseph H. Pleck, The Myth of Masculinity (Cambridge: MIT Press, 1981).
} 
first to recognize the need for a more complete and balanced view of manhood. ${ }^{53}$ In reference to the antebellum United States perhaps the most important influence on masculinity was industrialization. Among those scholars who have studied the impact of industrialization on male gender roles are Mary P. Ryan, Elizabeth and Joseph Pleck, Jack Nichols, Jack Sawyer, Eleanor Maccoby, Carol Jacklin, and Perry Treadwell. ${ }^{54}$

But while these scholars and others such as Sean Wilentz and David Leverenz have dealt largely with northern masculinity, Bertram Wyatt-Brown, W.J. Cash, and Charles Sydnor have chosen to emphasize southern gender roles. This dissertation, by examining both northerners and southerners, represents a more comprehensive examination of antebellum gender roles and their relationship to sectionalism and will hopefully provide a better understanding of both antebellum gender roles and the coming of the Civil War. ${ }^{55}$

In examining the existing schools of thought on the causes of the Civil War, two ideas readily come to mind. While it must be admitted that each of these interpretations contains some elements of truth one is forced to agree with Donald and Stampp that none of them, by themselves, offers a satisfactory explanation as to why the war occurred. In part this is because each of them has hit upon part of the answer. But by focusing on one factor as being the sole cause of the war they have failed to see the "big picture." The fact that Kenneth Stampp

\footnotetext{
${ }^{53}$ Gerda Lerner, The Creation of Patriarchy (New York: Oxford University Press, 1986.

${ }^{54}$ Mary P. Ryan, Cradle of the Middle Class: The Family in Oneida County, New York, 1790-1865 (Cambridge: Cambridge University Press, 1981); Elizabeth and Joseph Pleck in The American Man (Englewood Cliffs, N.J.: Prentice-Hall, 1980; See also Jack Nichols, Men's Liberation: A New Definition of Masculinity (New York, 1975); Joseph H. Pleck and Jack Sawyer, eds., Men and Masculinity (Englewood Cliffs, N.J.: Prentice-Hall, 1974); Eleanor Maccoby and Carol Jacklin, The Psychology of Sex Differences (Stanford: Stanford University Press, 1974); Perry Treadwell, "Biologic Influences on Masculinity," in Harry Brod, ed., The Making of Masculinities (Boston: Allen \& Unwin, 1987); Introduction, Carnes and Griffen, ed.,4, 6-7.

${ }^{55}$ Sean Wilentz, Chants Democratic: New York City and the Rise of the American Working Class, 17881850 (New York: Oxford University Press, 1984); David Leverenz, Manhood and the American Renaissance (Ithaca, New York: Cornell University Press, 1989), 1-4
} 
attempted such a comprehensive approach in The Causes of the Civil War, and even identified seven distinct categories of causes, yet was forced to admit defeat, indicates that the question is more complex than even Stampp envisioned. The second thought that comes to mind is these scholars, including Donald and Stampp, have in a sense been answering the wrong question. To one degree or another, they have all been attempting to explain disunion not the war.

In attempting to explain the causes of the Civil War it is necessary to ask two fundamental questions: why did the South secede and why did secession lead to war? Cultural dissonance, economic rivalry, and slavery at least partially explain why the South seceded but cannot explain why secession led to war. Slavery, tariffs, and state rights may have led the South to secede, but they cannot tell us why Presidents Lincoln and Davis each made a conscious decision to go to war. Clearly there was something more at work. To restate Donald, the American Civil War would never have occurred if Davis had not chosen to fight for southern independence and if Lincoln had "acquiesced in the peaceful secession of the South."56

Assessing why Davis chose to fight and why Lincoln chose not to "acquiesce" forms the central theme of this dissertation. What was that "something more" that was at work? It is my contention that $19^{\text {th }}$ century concepts of masculinity and manhood were the key factors that ensured that secession would result in war. Masculinity represents the missing link in explaining why a dispute over state sovereignty and property rights led to war.

In so doing it seeks to bring a fresh perspective to the question of Civil War causation; to look at it in a way that has never been done before. Finally in reexamining the issue of Civil War causation, one that has all too often been preoccupied with abstract political and economic

\footnotetext{
${ }^{56}$ Donald, Excess, 5-6.
} 
concepts, it will hopefully return the human element to its rightful place at the center of Civil War history. 


\section{CHAPTER 2}

\section{CONCEPTS OF MANHOOD:}

In order to fully understand how antebellum masculinity contributed to the coming of the Civil War it is first necessary to understand the nature of antebellum masculinity itself. This is no easy task given the fact that concepts of masculinity have varied greatly according to specifics of time, place, and class. Manhood has meant different things to different people at different times. Even among social scientists no clear consensus exists regarding the nature of male behavior and such questions as whether men are naturally aggressive or whether aggression has been programmed into them by society are fiercely debated. In the interest of brevity this study will avoid such hypothetical questions and instead focus its attention on describing masculine gender roles as they actually existed in antebellum America. ${ }^{57}$

Given the somewhat nebulous nature of masculinity, one should not be surprised to learn that antebellum concepts of masculinity, like so many other aspects of antebellum culture, were similarly ill-defined. Further complicating matters was the matter of sectional misperceptions. Both northerners and southerners tended to view their sectional counterparts in stereotypical terms. Northerners viewed white Southerners either as poor, ignorant, shiftless, 'crackers' or as aristocratic cotton snobs. Southerners, conversely looked upon Northerners as bookish, effete, cowardly shopkeepers. Unfortunately these stereotypes have to a large degree been perpetuated in modern views of the antebellum North and South. One of the most difficult tasks for

\footnotetext{
${ }^{57}$ Peter N. Stearns, Be A Man! Males in Modern Society (New York: Holmes \& Meier Publishers, Inc., 1979), 2-4; Steven Goldberg, The Inevitability of Patriarchy, New York, 1973), 3.
} 
historians of this period is to break through these stereotypes and uncover the true nature of antebellum masculinity.

Uncovering the 'true nature' of antebellum masculinity in all of its complexity represents the central thrust of this chapter, beginning with the "Ideal Types" of Southern Cavaliers and Northern Yankees, then turning to more popularly-oriented forms of masculinity associated with the lower and working classes in the North and South, then exploring the forms of masculinity found on the western frontier. Finally it will describe how the influx of migrants from the East helped to create a unique combination of the forms of masculinities found among 'Cavaliers' and 'Yankees'. It will conclude by detailing the rather considerable common traits shared by these various masculinities and the significance of those commonalities.

\section{--Southern Cavaliers--}

Southern manhood has long been a popular topic of historical investigation.

Traditionally, most of the studies done on Southern manhood have tended to focus upon the planter elite. Among members of the planter elite, and especially those living in the Tidewater regions of Virginia and South Carolina, the concept of southern manhood was largely composed of a set of behaviors and ethical standards that have come to be referred to as "Southern Chivalry." White southern males learned at an early age to think of themselves as the better sort and to conform to a strict code of conduct. ${ }^{58}$

\footnotetext{
${ }^{58}$ John Fraser, America and the Patterns of Chivalry (Cambridge: Cambridge University Press, 1982), 12; Thomas J. Wertenbaker, Patrician and Plebeian in Virginia or the Origin and Development of the Social Classes of the Old Dominion (New York: Russell \& Russell, 1959), 1 \& 7.
} 
The development of these standards of male behavior occurred partly by accident and partly by design. In "transplanting" their culture to the New World the English colonists, along with language and religion, brought traditional English social mores, including English concepts of gender identity, with them. In the years following Bacon's Rebellion, as slavery became woven into the fabric of Virginia society, and as planters began more and more to emulate the English gentry, they came to embrace the idea of the planter-as-aristocrat. ${ }^{59}$ A marked change in the attitudes and behavior of the planter class took place in the years following Bacon's Rebellion. As these changes took place, members of the planter elite came to embrace certain qualities, including morality, martial spirit, religious piety, veneration of women, and perhaps most important honor, often associated with chivalry. ${ }^{60}$

\footnotetext{
${ }^{59}$ Michal Rozbicki in The Complete Colonial Gentleman: Cultural Legitimacy in Plantation America makes note of a recent work by Kenneth Lockridge on William Byrd, in which Lockridge compares British culture, "and specifically its model of the gentleman to which Byrd-like so many of his Virginian contemporaries-intensely aspired" to a 'cage.' The British model of male behavior is depicted as "culturally restrictive and its pursuit as resulting in an artificial and rigid gentility, incompatible with the emerging democratic society in America." Kenneth Lockridge, The Diary and Life of William Byrd II of Virginia, 1674-1744 (Chapel Hill:, N.C., 1987), 151, 153, 143, 134, 49, 65; as cited in Michal J. Rozbicki The Complete Colonial Gentleman: Cultural Legitimacy in Plantation America (Charlottesville: University Press of Virginia, 1998) 16; also Rozbicki, 12, 37 \& 59.

${ }^{60}$ Among the few descriptive texts on 'chivalry' are Baldesar Castiglione's The Book of the Courtier and Sir Thomas Malory's Le Morte D’Arthur. According to Castiglione and Malory a "gentleman” should possess the following characteristics: piety, morality, truthfulness, mercy, gentleness, courtesy, wisdom, prudence, generosity, justice, modesty, scholarliness, respect for women, physical strength, agility and "a strong martial spirit." He should practice moderation in his personal habits and should neither eat nor drink to excess, nor act "like a peasant who stinks of the soil a mile off." Of all these qualities the most prized were duty, loyalty, and especially honor. In First Gentlemen of Virginia, Louis B. Wright established a nearly identical set of criteria for Virginia "gentleman." Wright, like Castiglione and Malory, also ranked honor as the foremost ideal of a gentleman calling it "the very mainspring of his actions." Baldesar Castiglione, The Book of the Courtier (New York: Penguin Books, 1967) 6062, 251; Sir Thomas Malory, Le Morte D’Arthur, (London: J.M. Dent; New York: E.P. Dutton, 1947) xiii \& 57; Louis B. Wright, First Gentlemen of Virginia (San Marino, California: The Huntington Library: 1940), 8-14; Roman Lull, The Book of the Order of Chivalry, trans. William Caxton, ed. A.T.P. Byles, Early English Text Society o.s. 168. London, 1926) 57 \& 58; Beverly Kennedy, Knighthood in the Morte D’Arthur, (Woodbridge, Suffolk, U.K.; Rochester,: D.S. Brewer, 1992) 15 \& 45; Wertenbaker, 54, 67-8, 80, 83, 85-6, 96, 99-100, 104-5; McPherson, 313, Ted Ownby, Subduing Satan: Religion, Recreation, and Manhood in the Rural South, 1865-1920 (Chapel Hill: The University of North Carolina Press, 1990), 34; David M. Potter, The Impending Crisis: 1848-1861 (New York: Harper \& Row, 1976), 377 458; Rozbicki, 13, 14.
} 
To cite but a few examples of these changes in attitude, militarily Virginians during the early period of settlement did not always conduct themselves with proper decorum or courage. This was clearly illustrated during Bacon's Rebellion when the rebels used female captives as human shields during their September 1676 attack on Jamestown, hardly a chivalrous act. But as Wright notes, by 1756 the planters had developed a "chivalric love of warfare not unlike that of the knights of old." This 'love of warfare' developed into a militarism that became one of the defining characteristics of the Old South. ${ }^{61}$ In the decades to come, Southerners contributed a larger percentage of men to the War of 1812 and the Mexican War than the North; they had more than their share of secretaries of war and the navy, of senior army officers, and of West Point cadets, not to mention providing numerous faculty and administrators at the Military Academy. The southern interest in militia service (there were twenty-two units in Charleston alone at one time) for military colleges and for military academies were all strong indicators of the degree to which southerners embraced the warrior ethos. ${ }^{62}$

In reference to the treatment accorded women, the change is again striking. As Wertenbaker notes, veneration of women was one of the highest ideals of chivalry and, like militarism, respect for women would become one of the hallmarks of southern culture. Indeed it

${ }^{61}$ Castiglione, 60-62, 251; Malory, xiii \& 57; Wright, 8-14; Nicole Etcheson, "Manliness and the Political Culture of the Old Northwest, 1790-1860", Journal of the Early Republic Vol 15, (Spring, 1995) 71; Lull, 57 \& 58; Kennedy, Knighthood, 15 \& 45; Wertenbaker, 67-8, 80, 83, 85-6, 96, 99-100, 104-5; McPherson, 313, Potter, 458; Ownby, 34.

\footnotetext{
${ }^{62}$ R Don Higginbotham, "The Martial Spirit in the Antebellum South: Some Further Speculations in a National Context,: Journal of Southern History (hereafter JSH), Vol. 58, \# 1 (Feb. 1992) 5.
} 
is difficult to imagine Robert E. Lee or Stonewall Jackson resorting to the use of women, even slave women, as human shields. ${ }^{63}$

Southern chivalry and southern gender roles in general were closely tied to the system of plantation slavery. Just as slaveholders indoctrinated blacks to their status as slaves so were upper-class southern whites indoctrinated to their status as masters. But whereas slaves learned submission and obedience; upper class whites learned dominance and command. Given the nature of southern society, and especially the need to control a large slave population, this indoctrination process was essential to the maintenance of the socio-economic structure of the region. For the plantation system to survive, it had to develop a cadre of strong, aggressive, males capable of sustaining it. ${ }^{64}$ All of these factors, when combined with the wealth, isolation, and nearly autocratic authority that plantation slavery afforded, bred within planters a belief that they were superior not only to their slaves but to their poorer white neighbors as well. ${ }^{65}$ Charles Sydnor, in Gentleman Freeholders quotes one plantation visitor as saying:

${ }^{63}$ Castiglione, 60-62, 251; Malory, xiii \& 57; Wright, 8-14; Etcheson, "Manliness, 71; Lull, 57 \& 58; Kennedy, 15 \& 45; Wertenbaker, 67-8, 80, 83, 85-6, 96, 99-100, 104-5; General A.L. Long, Memoirs of Robert E. Lee, (Charlottesville, 1886), 88; McPherson, 313, Potter, 458; Ownby, 34.

${ }^{64}$ W.J. Cash, The Mind of the South (New York: Alfred A. Knopf, 1941), 3-4, 6; Wertenbaker, 2-4, 9, 23, 28, 29 \& 61; James Horn, "Cavalier Culture? The Social Development of Colonial Virginia," William \& Mary Quarterly, 48, (1991): 239-240; Bernard Bailyn, "Politics and Social Structure in Virginia," Seventeenth-Century America: Essays in Colonial History, James Martin Smith, ed. (Chapel Hill, N.C.: University of North Carolina Press, 1959), 98-10; Edmund S. Morgan, American Slavery, American Freedom, The Ordeal of Colonial Virginia (New York: W. W. Norton \& Company, Inc., 1975), 251-253, 259-262, 264-6, 272, 297-300; see also Wilcomb E. Washburn, The Governor and The Rebel: A History of Bacon's Rebellion in Virginia (Chapel Hill: The University of North Carolina Press 1957); Stephens Saunders Webb, 1676: The End of American Independence (Syracuse: Syracuse University Press, 1995); Peter Kolchin, American Slavery 1619-1877 (New York: Hill and Wang), 11-13); Stephen Saunders Webb, Lord Churchill's Coup: The Anglo-American Empire and the Glorious Revolution Reconsidered (New York: Alfred A. Knopf, 1995); Edward R. Crowther, "Holy Honor: Sacred and Secular in the Old South," JSH Vol. 58, No. 4 (November, 1992) 620.

${ }^{65}$ William W. Freehling, The Road to Disunion: Secessionists at Bay, 1776-1854 (New York: Oxford University Press, 1990) 164, 166, 173, 176-7; Martin Crawford, "Political Society in the Southern Mountain 
The solitary elevation of a country gentleman, well to do in the world, begets some magnificent notions. He becomes as infallible as the Pope; gradually acquires a habit of making long speeches; is apt to be impatient of contradiction, and is always very touchy in the subject of honor. ${ }^{66}$

Another essential part of Southern manhood was the idea, closely associated with the idea of Southern Chivalry, that southern slaveholders were the defenders of White Christian civilization. White southerners argued that just as imperialist expansion brought the blessings of Christianity and progress to the backwards peoples of the world, southerners, in promoting and defending slavery, were similarly carrying out a civilizing mission among Africans. Southern clergy, for their part, entered into a sort of "devil's bargain" in which they agreed not to question the legitimacy of slavery and actually defended it from attacks from Northern evangelicals like Wendell Phillips through Biblical decrees that servants should "obey their masters." In exchange, slaveowners supported clergymen in their "mission" to christianize slaves. ${ }^{67}$

It is important to remember that the original purpose of chivalry was to exert a civilizing influence over males, to establish a standard of behavior that could bring order to society through

Community: Ashe County, North Carolina, 1850-1861," JSH, Vol. 55, \# 3, (August, 1989), 373-390; Stephen V.

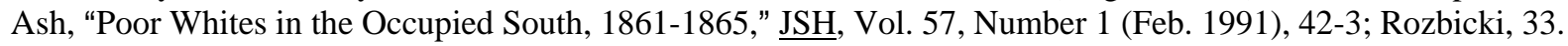

${ }^{66}$ John P. Kennedy, Swallow Barn ... (New York: 1866), 35. as quoted in Charles S. Sydnor, Gentleman Freeholders: Political Practices in Washington's Virginia (Chapel Hill: The University of North Carolina Press, 1952), 5-6; see also Rowland Berthoff, "Peasants and Artisans, Puritans and Republicans: Personal Liberty and Communal Equality in American History," The Journal of American History (hereafter, $\underline{\text { JAH}}$ ), Vol. 69, \# 3 (December 1982), 594 ; Rozbicki, 33.

${ }^{67}$ Evangelicalism also provided planters with a convenient rationale to justify their patriarchal control over their wives and children. Bertram Wyatt-Brown, Southern Honor: Ethics \& Behavior in the Old South, (Oxford: Oxford University Press, 1982) 101; Cash, 79-82; Kenneth M. Stampp, The Peculiar Institution: Slavery in the Antebellum South (Publication data) 159; Freehling, 65-66, 191; Crowther, "Holy Honor," 619, 623, 627-629, 632, 633.; Seymour Drescher, "Servile Insurrection and John Brown's Body in Europe," JAH, vol. 80, Issue 2 (Sep. 1993), 503, also 506, 511; Carl N. Degler, Neither Black nor White: Slavery and Race Relations in Brazil and the United States (New York: Macmillan Publishing Co., 1971), 35, 85. 
mastery of the primal drives of appetite, sexuality and aggression. ${ }^{68}$ As such it was closely tied to concepts of power and the preservation of the established social order. But as Eugene Genovese has pointed out slavery was not only a social institution it was also an economic institution. In as much as Southern chivalry was closely tied to that institution, it became the duty of every southern gentleman to maintain not only the social and political stability of the South but its economic stability as well. This is the critical point. The maintenance of the plantation system depended upon the creation of a master class that was capable of controlling the slaves without which the economic and social system of the South would have crumbled. ${ }^{69}$

Despite its pretensions of exerting a civilizing influence, Southern manhood had its dark side as well. In some circles, especially among evangelical Christians, southern men were seen as being less emotional and less moral than women. Women, by and large, were much more likely to join and attend church than men. Some scholars attribute this lack of religiosity to the fact that "evangelicals favored an ideal of tenderness and docility more often associated with women than men." Whatever the cause, southern men were not only less likely to attend church than women but they also regularly indulged in such "sins" as drinking, swearing, fighting and wenching. $^{70}$

\footnotetext{
${ }^{68}$ Crowther, 628, 629; Rozbicki, 31-32.

${ }^{69}$ Eugene Genovese, The World The Slaveholders Made: Two essays in interpretation (Middletown, Conn.: Wesleyan University Press, 1988) 32-3, 102-5.

${ }^{70}$ There is some disagreement on this point. Ted Ownby discounts the importance of religion to southern males, citing a survey of church rolls from the post-war period noting that "between 1868 and 1906 women constituted about 62 percent of the churches' members" or 1830 out of 2989 total church members." Edward
} 
Of course all of these factors--morality, martial spirit, respect for women and honor-found expression in that most deadly component of southern culture: the code-duello. Nothing else so clearly illustrates the planters' growing aristocratic self-image as the increasing prevalence of dueling. Aside from its more obvious aspects--the need to prove one's courage and the fact that "affairs of honor" often involved the reputation of a lady--there was also within the code-duello the implicit understanding that it was intended to be a civilized means of settling disputes among gentlemen. Gentlemen, and gentlemen only, engaged in dueling. One did not challenge, nor accept challenges from, one's social inferiors. ${ }^{71}$

The fact that duels, which were practically unknown in the seventeenth century, by the time of the Civil War occurred throughout the South is another strong indication that upper class white Virginians were coming to think of themselves as 'gentlemen' and emulating the nobility in word and in deed. They referred to each other by the semi-noble title of 'Squire', dressed in the most expensive tastes and built elegant homes with names that still resound with the echoes

Crowther on the other hand argues that while "Most southerners were not church members . . Eyewitness accounts of worship services and revivals describe attendance in figures far greater than membership rolls imply. In 1855 a British traveler found that the two Presbyterian congregations in Lexington, Kentucky, had but 300 members between them but noted that about 1200 souls routinely attended Presbyterian services." In other words, just because men did not join churches did not mean that they did not attend services or were otherwise devout. Ownby, 11, 45, 49, 129; Crowther, "Holy Honor," 620, 624, 628; Gail Bederman, “The Women Have Had Charge of the Church Work Long Enough': The Men and Religion Forward Movement of 1911-1912 and the Masculinization of Middle Class Protestantism," American Quarterly, Vol. 41, No. 3 (September, 1989) 432.; Christopher Waldrep, "The Making of Border Society: James McCready, The Great Revival, and the Prosecution of Profanity in Kentucky," The American Historical Review, (hereafter AHR) Vol. 99, No. 3 (Jun. 1994) 769; Paula Baker, "The Domestication of Politics: Women and American Political Society, 1780-1920," AHR Vol. 89, No. 3 (Jun., 1984) 620.

${ }^{71}$ Christopher J. Olsen, Political Culture and Secession in Mississippi: Masculinity, Honor, and the Antiparty Tradition, 1830-1860 (Oxford: Oxford University Press, 2000), 121, 172; Castiglione, 117-18; Crowther, "Holy Honor," 628. 
of an American nobility such as Shirley, Berkeley, and Monticello. ${ }^{72}$ William W. Freehling, in Road to Disunion, conveys the importance of such symbolism: "An elitist's palatial house symbolized a world in which betters ruled lessers of all races. Poorer visitors came to grand mansions with a deferential attitude."73 One of the most important ways in which members of the planter class attempted to not just emulate the British nobility but to actually join that nobility was through the acquisition of a family coat of arms. As Michal Rozbicki writes:

For the seventeenth century Virginian, William Fitzhugh, a coat of arms carried an immense value that was placed on it by preceding centuries of British culture, and we should not expect him to have rejected its meaning in favor of future American egalitarianism. $^{74}$

Southerners also displayed their aristocratic pretensions through the use of military titles. European titles of nobility being unobtainable or inappropriate, planters settled for the next best thing, military titles. Often, though not always, denoting a rank in the militia, such titles quickly became ornaments of honor and functioned not only during periodic musters-which, of course,

\footnotetext{
${ }^{72}$ Fraser relates a bizarre example of this desire to emulate European nobility from 1845 which involved a group of Virginians, clad in full armor, taking part in a ring tournament. Fraser, 8; Rhys Isaac, The Transformation of Virginia, 1740-1790, (Published For the Institute of Early American History and Culture Williamsburg, Va. Chapel Hill: University of North Carolina Press: 1982) 34-42, 131-135; Wertenbaker, 34, 39, 54, 74, 80, 87 \& 125; See also, Mary Beth Norton, Founding Mothers \& Fathers: Gendered Power and the Forming of American Society. (New York: Vintage Books, 1996) 190; Wyatt-Brown, 23, 15-24; Kennedy, 152; Lull, 36-38, 57, 58; Webb, 1676, 211-12.Marcia Brunell, Bready, "A Cavalier in Virginia-The Right Honorable Sir William Berkeley, His Majesty's Governor," William \& Mary Quarterly Historical Magazine, 1990; Ownby, 68, Morgan, 35; Sydnor, 5-6; Rozbicki, 22, 75, 155.

${ }^{73}$ Freehling, 166.

${ }^{74}$ Rozbicki sees in this fascination with coats of arms an example "of the legitimizing power of pedigree" noting that "in Virginia nearly all of the prominent gentry families sooner or later made claims to coats of arms." Rozbicki, 20 \& 44.
} 
provided a unique opportunity for the local commissioned gentlemen to emphasize the desirable order of precedence in society. ${ }^{75}$

It should be noted, however, that despite their best efforts at acquiring 'gentility' the European nobility never accepted the American planter class as equals. As Rozbicki puts it:

Both the first and second generations of colonial gentry ... found themselves continually treated by the metropolitan elites as rustic and boorish usurpers to gentility at best and as an inferior, vulgar sort of Englishman at worst. ${ }^{76}$

\section{--Northern Yankees--}

Although they shared many common traits, Northern ideas of manhood were more complex than those of the South. This is hardly surprising given the fact that Northern society as a whole was more diverse and less homogenous than the South. Their concepts of manhood varied not only among different ethnic cultures but among geographic and social groups as well. In other words different classes and different regions, just like different ethnic groups, tended to have their own ideas about what it took to be a man.

As was previously stated, southerners tended to stereotype Northerners as being either effete intellectuals or, more often, as "pallid, urban-dwelling, factory workers." They naturally regarded such people as cowardly and more concerned with profits than with personal honor. ${ }^{77}$ Like most stereotypes, this one grossly oversimplified reality. Northern ideas of masculinity

${ }^{75}$ Ibid., 155.

${ }^{76}$ It bears noting that planters in the West Indies displayed a similar fascination with the European nobility and were similarly unsuccessful in gaining their acceptance. Ibid., 79.

${ }^{77}$ Higginbotham, "Martial Spirit," 16; Donald Bellows, "A Study of British Conservative Reaction to the American Civil War," JSH, Vol. 51, No. 4, (November, 1985) 517; Colin Creighteon, "The Rise of the Male Breadwinner Family: A Reappraisal." Comparative Studies in Society and History, Vol. 38, No. 2 (April, 1996), 323-324. 
were more varied than southerners could have ever imagined. Among the business and professional classes, especially in New England but throughout the Northeast, concepts of manhood were heavily influenced by capitalist economics. In fact economic competition provided a crucial test of manhood. While Southerners sought to prove their manhood through physical combat and violent confrontation, middle class Northern professionals demonstrated manliness through economic productivity. As Nicole Etcheson puts it: "Real men provide for and protect their dependents. The most manly is the most successful male--the one who accumulates the most wealth or accomplishes the most feats of derring-do." ${ }^{78}$

Beyond that, males in the Northeastern business and professional classes adopted a bourgeois sense of morality that was deeply rooted in evangelical ideals of masculinity which had as their model the 'self-restrained Christian gentleman and which espoused such virtues as thrift, piety, "domestic harmony," sobriety, civic-mindedness, and intelligence. As was the case elsewhere "Yankees" drew a strong connection between manly virtue and republicanism. Stated succinctly, the stability of the political system was dependent upon the ability of individuals to restrain their baser instincts. For them "self-government" was to be taken both literally and figuratively. There was a natural connection between the two; on the most basic level masculinity was important to politics because to the nineteenth century mind, manhood was equated with power. ${ }^{79}$ In fact so closely were manhood and politics associated, that political

\footnotetext{
${ }^{78}$ Etcheson, "Manliness," 61 \& 62.
}

${ }^{79}$ Norma Basch, "Marriage, Morals, and Politics in the Election of 1828," JAH, Vol. 80, No. 3, (December, 1993), 892-894., 895-896; 901; Elliott J. Gorn, “'Good-Bye Boys, I Die a True American': Homicide, Nativism, and Working-Class Culture in Antebellum New York City," JAH, Vol. 74, No. 2 (Sept., 1987), 401, 403, 404, 405, 406, 407; Introduction, Meanings for Manhood: Constructions of Masculinity in Victorian America, Mark C. Carnes and Clyde Griffen ed., (Chicago: University of Chicago Press, 1990); T.H. Breen, Timothy Hall, "Structuring Provincial 
candidates often attempted to denigrate their opponents by 'feminizing' them through language often associated with women, referring to them by terms such as "effeminate, dandy, fop, sissy, and sodomite." 80

Southern stereotypes of Northerners as less warlike and more concerned with business and commerce are well documented. For years many historians even accepted them as fact. According to southern mythology, Yankees were the descendants of Anglo-Saxons and "Southerners (were) the descendants of their Norman Conquerors." That there was not a word of truth in such stereotypes made little difference to those who believed them, the point was clear: southerners were born to rule, Yankees were born to be ruled; southerners had fighting ability and martial virtue in their blood; Yankees were the descendants of a "degraded conquered race." ${ }^{81}$

Since the 1960s a different view of New Englanders has emerged spearheaded by Marcus Cunliffe and his student Michael C.C. Adams. According to Cunliffe and Adams, New England had a very long and prominent martial tradition of its own. ${ }^{82}$ Citing as evidence such factors as the popularity of militia service, the savage warfare waged by Puritan Massachusetts during King Philip's War and a "staggering quantity of military literature (published) prior to 1776" Cunliffe

Imagination in the Rhetoric and Experience of Social Change in Eighteenth Century New England," AHR, Vol. 103, No. 5 (December, 1998) 1420; Anna Clark, "The Chevalier d'Eon and Wilkes: Masculinity and Politics in the Eighteenth Century," Eighteenth Century Studies, Vol. 32, No. 1, (1998), 20.

${ }^{80}$ Clark, "Chevalier d’Eon,"19; Jo Burr Margadant, "Gender, Vice, and the Political Imaginary in PostRevolutionary France: Reinterpreting the Failure of the July Monarchy, 1830-1848," AHR, Vol. 104, No. 5, (December, 1999) 1473 .

\footnotetext{
${ }^{81}$ Rozbicki, 66-67; McPherson, 196-197.

${ }^{82}$ Higginbotham, "Martial Spirit," 3.
} 
and Adams assert that "New Englanders thought of themselves as a brave and warlike people and . . they considered themselves in these respects superior to colonial southerners." ${ }^{83}$ Furthermore, Cunliffe and Adams, citing the work of George W. Pierson, go so far as to state that New England militarism, so prominent in the colonial period, was still alive and well by $1860 .^{84}$

But on the other hand it should be mentioned that southern stereotypes of Northerners as being less than 'masculine' were not entirely without basis. While the "self assertive, acquisitive, power-hungry" form of masculinity remained the norm in both North and South, Cynthia GriffinWolff points out that there arose, in certain areas of the North, a form of masculinity that was decidedly at odds with the "image of ruthless, power-hungry American manhood" that was so much a part of antebellum American culture. ${ }^{85}$

This effort to "redefine masculinity" had its origins and found its most receptive audience in the ranks of the antebellum social reform movements and especially within the abolitionist and peace movements. Members of these movements came to deplore the aggressive form of masculinity that seemed to dominate male behavior in antebellum America. As the social reform movements represented one of the few opportunities for women to participate in public life

${ }^{83}$ Ibid., 6-7, 9, 14.

${ }^{84}$ Recently James McPherson has taken issue with Cunliffe's and Adams's conclusions, and the evidence they cited, arguing that the two, in citing the relative popularity of militia companies in North and South, the two did not take population of each region into account and had they done so "it would probably support the traditional view of a higher concentration of such companies in the South." McPherson further argues that Cunliffe and Adams failed to account for the presence of southern slave patrols which had no counterpart in the North. McPherson concluded that "When Southerners labeled themselves a nation of warriors and Yankees a nation of shopkeepers ... they were not just whistling Dixie." James McPherson, "The Differences between the Antebellum North and South," Major Problems in the Civil War and Reconstruction Michael Perman, ed., (Boston: Houghton-Mifflin, 1998) 2627; Higginbotham, "Martial Spirit," 13 \& 24.

${ }^{85}$ Cynthia Griffin Wolff, “'Masculinity' in Uncle Tom's Cabin,” American Quarterly, Vol. 47, Issue 4 (Dec., 1995), 598-599; Kristin Hoganson, "Garrisonian Abolitionists and the Rhetoric of Gender, 1850-1860," American Quarterly Vol. 45, No. 4 (December, 1993), 558. 
outside the home, it only made sense that the male members of these societies would be influenced by women. Under the influence of their female colleagues, many male reformers came to see this aggression-based form of masculinity as being the cause of many of the social ills that they were trying to cure, including slavery, the oppression of women and native Americans, and the Mexican War. ${ }^{86}$

Indeed abolitionists, many of them evangelical Christians, argued that slavery and the entire social system of the South was "an internalized, systematized, and legally perpetuated enactment of conquest and colonization. ..”87 As long as American culture continued to not only tolerate but to glorify conquest and aggression, slavery, as the most extreme form of that aggression, would never be eradicated. And since so much of American culture was bound up with masculinity, "effective abolition, then required a redefinition of the roles of men and women and of each member's rights and duties in an honorable Republic." In response men like the abolitionist William Jay began to formulate an alternative version of both masculinity and patriotism, one that instead of violent conquest and aggression, emphasized a "benevolence, which springs from moral goodness. The new standard by which male behavior should be judged, was by what Jay and others termed "fraternal love."88

\footnotetext{
${ }^{86}$ Griffin-Wolff, “‘Masculinity,” 599; Hoganson, "Garrisonian Abolitionists,” 565..

${ }^{87}$ Griffin-Wolff, “'Masculinity,” 600.

${ }^{88}$ Griffin-Wolff characterizes this change as "a return to Revolutionary and pre-Revolutionary mores-that is, a revival of notions of masculinity that prized communal well-being over ruthless individual acquisition." I think this is a bit of naivete on the part of either Griffin-Wolff or the abolitionists. In light of some of the actions of the Puritan father during King Philip's War and those of Samuel Adams and his Sons of Liberty during the Revolutionary period, one is especially reminded of the burning of the home of Governor Thomas Hutchinson by a mob, while the New England forebears may have prized "communal well-being over ruthless individual acquisition" that didn't necessarily make them any less violent than their nineteenth century descendants. Griffin-Wolff, “'Masculinity,” 600, 597; Eric L. Haralson, "Mars in Petticoats: Longfellow and Sentimental Masculinity,”
} 
For radical abolitionists such as Henry Ward Beecher, Gerrit Smith, and William Lloyd Garrison, fraternal love was the underlying basis for their belief that "wide-sweeping reform was to be achieved solely by means of moral suasion and nonviolent resistance." Indeed Smith, Beecher, and other abolitionists attempted to adopt "fraternal love" and the "more compassionate, less aggressive" definition of manhood into their daily lives and to "entirely repudiate competition and conquest as the basis for masculine relationships." ${ }^{89}$

Given the fact that so many abolitionists came from an evangelical Christian background, it was only to be expected that many of them would point to Jesus Christ as the model of this new version of masculinity. Indeed, Jesus seemed to embody many of the traits associated with this new version of manhood: compassion, cooperation, indifference to material gain, concern for the less fortunate. Most importantly, rather than forcibly impose his views on others, Jesus had passively suffered torture for what he believed. This new version of manhood, then, called for a Christ-like compassion and emphasized non violent resistance to bring about social change. The highest form (or ideal) of manhood was that of the martyr who suffered serious injury, even death, to defeat evil. ${ }^{90}$

It should also be pointed out however that there was considerable opposition, even within the abolitionist movement, to this new, more passive version of masculinity. Some, like Henry James Sr., feared that what they called "the virile sense" of Puritanism was being emasculated Nineteenth Century Literature Vol. 51, No. 3 (December, 1996) 329; Hoganson, “Garrisonian Abolitionists," 561.

${ }^{89}$ Indeed many adherents of this new "compassionate form of masculinity" went so far as to "routinely" exchange kisses when meeting and write each other 'passionate' letters. In this light any allegations of homosexuality based upon such displays of "lavish affections between men" may be regarded with suspicion. Griffin-Wolff, "'Masculinity,” 601-602; Haralson, 336, 346.

\footnotetext{
${ }^{90}$ Griffin-Wolff, “'Masculinity,” 601-2 .
} 
"by a feeble Unitarian sentimentality." Criticism also came from Black Abolitionists like David Walker who pointed out that such a passive approach to slavery resistance, even if it was based on the teachings of Christ, might take decades to bring results, if it worked at all. Slavery, they argued, had to be actively resisted. Aggressive force had to be met by aggressive force. That was the only way to rid the land of the sin of slavery. ${ }^{91}$

But Garrison, Samuel J. May, Henry Ward Beecher and others insisted that non-violent resistance was the only moral choice. Two wrongs, they argued, did not make a right, and since violence was always wrong, meeting violence with violence was wrong. They insisted that abolitionists must seek the moral high ground and the only way to do that was to follow Christ's example of renouncing violence. Garrison, May, Beecher and their colleagues would fight slavery not by fighting, but by playing the martyr. They would suffer pain, violence even death, "under all such provocations, they were obliged to respond with only passive resistance. They took blows but never returned them."92

This image of masculinity-defined-as martyrdom in part helps to explain the popularity of Uncle Tom's Cabin, whose main character, the slave Uncle Tom, seemed to perfectly embody those virtues associated with this new radical version of manhood. ${ }^{93}$ As Griffin-Wolff writes:

In her hero, Stowe constructed a man whose emotional and moral life is centered not on domination or competition but on the self-conscious, vigorous exercise of communal love-a man who unites the virtues of "kindliness and benevolence" with dignity and a "broad-chested" and "powerfully made" physique. Consistently, then Tom's "selfsacrifice" is not a manifestation of weakness but a potent and effective enactment of

\footnotetext{
${ }^{91}$ Griffin-Wolff, “'Masculinity,” 603; Haralson, 331 .

${ }^{92}$ Griffin Wolff, “'Masculinity,” 602, 603 .

${ }^{93}$ Ibid., 608 \& 598, 610, 611.
} 
social responsibility. . . .she postulates a black man as the exemplary model of this admirable behavior-a black man who is strong hearted enough to save far more people through the heroism of personal sacrifice than might ever have been saved through vicious battle. ${ }^{94}$

It also helps to explain the Northern reaction to John Brown's execution following his failed Harper's Ferry raid. To the modern observer Brown, in addition to perhaps being mentally unbalanced, seems as little more than a terrorist. That so many abolitionists adopted him as a martyred hero speaks directly to this image of passive, suffering, manhood. Regarding Brown's 1859 execution, British anti-slavery lecturer, George Thompson was said to have remarked that Brown "had better served the cause by failing and dying than he ever could have by succeeding." 95

Such notions of “feminized' masculinity were seen by mainstream males in both North and South as being radically extreme and further contributed to the marginalization of the abolitionists. To surrender patriarchal authority in the way that abolitionists advocated, would undermine not only men's social dominance, but their political dominance as well. Little wonder then that Southern slavery advocates characterized Garrison and other radical abolitionists as "unsexed" freaks who threatened to upset the entire structure of "conventional gender beliefs." By appealing in this way to Victorian social mores southerners attempted, not without some success, to portray the system of plantation slavery and patriarchal authority which lay at its heart, as a bulwark against such radical notions. Viewed from this perspective, slavery was not

\footnotetext{
${ }^{94}$ Ibid., 609 .

${ }^{95}$ Drescher, "Servile Insurrection,” 509, 518.
} 
an outdated relic from the feudal past, but an institution dedicated to preserving, as Southerners saw it, the natural order of society. ${ }^{96}$

Abolitionists answered these claims by attacking slavery on the grounds that it posed a mortal threat to the very same ideals of patriarchal authority that they had questioned in the first place. The real damage that slavery did was in the way that it "desexed all slaves and their masters." Specifically they charged that slavery undermined traditional family structures and destroyed the virtue of slave women who were frequently raped by their masters. ${ }^{97}$ As abolitionists saw it, Victorian America could not tolerate an institution that so "thoroughly corrupted middle-class gender norms."98

\section{--Class and Popular Politics--}

So far this chapter has been focused upon elite elements of the population: the planter class in the South; the business, professional, and intellectual classes in the North. These segments of the antebellum population obviously played an important role in the process of sectionalism. But as important as was the role played by the elites, that of the non-elite segments was equally important, if not more so. As David Donald pointed out in his lecture entitled "An Excess of Democracy: The American Civil War and the Social Process" the expansion of voting rights that resulted from the democratic forces unleashed during the Jeffersonian and Jacksonian eras made the political system increasingly sensitive to the will of the 'common man'. It only

\footnotetext{
${ }^{96}$ Hoganson, "Garrisonian Abolitionists," 563, 558-559; Stephanie McCurry, Masters of Small Worlds: Yeoman Households, Gender Relations, \& the Political Culture of the Antebellum South Carolina Low Country, (New York: Oxford University Press, 1995) 223, 224.

${ }^{97}$ Hoganson, “Garrisonian Abolitionists," 559, 560; McCurry, 40..

${ }^{98}$ Hoganson, "Garrisonian Abolitionists," 566, 560.
} 
makes sense, therefore, to explore notions of masculinity among non-elite segments of the northern and southern antebellum population. ${ }^{99}$

In the South, while the planters were transforming themselves into a self-styled nobility, the yeoman class and working class southerners continued to behave in the same hard-driving, two-fisted manner that had characterized male behavior since the earliest days of European settlement. The prolonged struggle to survive in a wilderness environment bred an image of manhood that emphasized strength: both physical strength and strength of character. ${ }^{100}$ A man was expected to look the part, brawn and a muscular physique directly spoke to the frontier ideal of manhood as one equipped for survival. ${ }^{101}$ Candor was another quality prized in Southern males. Real men were not afraid to speak their minds, regardless of the consequences. ${ }^{102}$ All of these qualities--brute strength, candor, courage, survival skill, and stoicism--together comprised a code of conduct and ethics which has been labeled by Bertram Wyatt-Brown and other scholars as "Southern Honor," a view which "which condemned effeminacy and expected men to be ferocious and aggressive." ${ }^{103}$ In short to be a man meant to be bold, dynamic, athletic, hard-

\footnotetext{
${ }^{99}$ Donald, Excess of Democracy, 8, 9, 10, 11, 12, 16, 28.

${ }^{100}$ Etcheson, "Manliness," 61-2.

${ }^{101}$ Ibid., 69.

${ }^{102}$ Ibid., 67, 69- 70.

${ }^{103}$ Ibid., 62; Ownby, 12.
} 
drinking, and handy with one's fists. ${ }^{104}$ At the heart of southern honor, according to Bertram Wyatt-Brown, was the maintenance of one's reputation before the public. ${ }^{105}$

Men were also expected to eschew the emotionalism that was often attributed to women.

Living day and night with the threat of violent death or with the knowledge that they might have to kill, men could not afford the luxury of sentimentality. ${ }^{106}$ In order to deal with the harsh reality of their daily lives men were expected to assume an attitude of unyielding stoicism-to betray no emotion. To shed so much as a tear would seriously call into question one's status as a man. In Subduing Satan Ted Ownby quotes one Southerner who recalled of his grandfather:

He did not frequent church any more than decorum required but he went at proper intervals and saw that I tagged along too. I soon learned that one reason for his spasmodic attendance was his loathing for the preacher, who was accustomed to work himself into a weeping spell over the sinfulness of man. 'Crying in the Pulpit, crying in the pulpit! A man ought to be a man even if he does wear a cloth.'107

But if there was a single characteristic that unified southern males of all classes it was a fascination for violence and fighting. Nearly all students of the Old South agree that the region had a strong propensity for violent conflict. From the duelist on the field of honor, to feuding hillbillies, to mythic brawlers such as Jim Bowie, Mike Fink and Davy Crockett, nineteenthcentury Southern males have been described by contemporaries and historians alike as "swaggering, belligerent ... quick to take offense, quick to go to war, and, when at war, quick to

${ }^{104}$ Ownby, 24, 44-46, 49, \& 81; Etcheson, "Manliness," 61.

${ }^{105}$ Etcheson, "Manliness," 63 \& 71; Ownby, 15.

${ }^{106}$ Ownby, 11, 126 \& 129.

${ }^{107}$ Louis B. Wright, Barefoot in Arcadia: Memories of a More Innocent Era, (Columbia: University of South Carolina Press: 1982) 38, as quoted in Ownby, 134. 
mount a direct assault."108 According to Christopher Olsen, historians and sociologists, as well as contemporaries, have commented on the high level of violence in the antebellum South.

According to an 1880 study by Horace Redfield, the homicide rate in the South, both before and after the war, was about ten times that in the North. ${ }^{109}$

This predilection for violence has been attributed to a number of factors including frontier conditions, the isolation and hard work of rural life, slavery and its cruelties, the chivalric traditions and ideals of the upper class, the Celtic origins of the plain folk, and even to climate. ${ }^{110}$ Redfield attributed the high southern murder rate to such factors as the South's greater availability of firearms, lack of law enforcement and an "exaggerated sense of honor that prompted men to seek redress for seemingly trivial insults." ${ }^{111}$ Whatever the cause, nearly every scholar of the antebellum South agrees that violent confrontation was a pervasive feature in the lives of Southern males. ${ }^{112}$

To a large degree this violence was tied to the strong desire, among antebellum southerners, to prove their worth as men; to show that they measured up to community standards

${ }^{108}$ Ownby, 13-6, 62, 78-81; Etcheson, "Manliness," 61; Wyatt-Brown, 352-61, 370; Grady McWhiney and Perry D. Jamieson, Attack and Die: Civil War Military Tactics and the Southern Heritage, (University, Alabama: The University of Alabama Press, 1982) Preface xv, 14-18; Isaacs, 95-104; Winthrop D. Jordan, White Over Black: American Attitudes Toward the Negro, 1550-1812, (Chapel Hill: University of North Carolina Press: 1968) 28-40.

${ }^{109}$ Redfield's figures did not include assaults against slaves, only incidents between whites. Data from Horace V. Redfield, Homicide, North and South: Being a Comparative View of Crime Against the Person in Several Parts of the United States (Philadelphia: 1880) cited in Olsen, 171.

110 Ownby attributes Southerners' fascination with violence to fear of violent slave uprisings. Ownby, 13 , 15-16, 62; Wyatt-Brown, 352-61, 370; McWhiney and Jamieson, Preface xv, 14-18; Isaacs, 95-104; Jordan, $28-40$. Olsen, 171-2; Etcheson, "Manliness," 61.

\footnotetext{
${ }^{111}$ Redfield, cited in Olsen, 171.

${ }^{112}$ Etcheson, "Manliness,” 62; Griffin-Wolff, “‘Masculinity’,” 598-600 .
} 
of manhood. This pressure to conform to community standards of proper male behavior was constant and intense. In a hierarchical, patriarchal, male-dominated society such as the antebellum South, this daily struggle for approval, acceptance, and respect could have tragic consequences and even the slightest insult could escalate into a deadly confrontation. Southerners of every class, be they planter, yeoman, blacksmith, or vagrant, took great care to protect their good name. To accept belittlement would proclaim to the entire community that one was not worthy of respect. The only acceptable response to such an insult was through ritualized violence. ${ }^{113}$ To win meant that one measured up as a man, to lose might mean temporary disgrace, but to refuse to take part in the ritual would mean exclusion from the community of men. ${ }^{114}$

The pressure to measure up was probably greater for non-planters than for planters. Having neither family fortune nor family name upon which to trade, the desire to make a name for themselves led non-planters to act even more aggressively in order to avoid the 'shame' of dishonor. This was especially true in rural areas and smaller communities where "men were highly conscious of their public reputation.”115 But whereas members of the planter class followed the code-duello as their ritualized means of settling disputes and maintaining 'honor' among the non-planter classes, "affairs of honor" were often carried out through less civilized, more rough and tumble methods such as "wrestling and grisly eye-gouging (and )street brawling,

${ }^{113}$ Etcheson, "Manliness," 62, 64; Ownby, 12-3; Olsen, 173.

${ }^{114}$ According to Christopher Waldrep, many in the border states saw profanity as playing a similar role to that of competition: "some contended that profane swearing served as a proxy for courage and assertiveness, promoting masculine honor ..." Waldrep, 767; Ownby, 13; Etcheson, Manliness, 65.

${ }^{115}$ Olsen, 172; Etcheson, "Manliness," 62; Crowther, "Holy Honor”, 620. 
(which) often degenerated into a more deadly confrontation. .."116 But as Christopher Olsen points out, these encounters were more than displays of barbarism, they performed an important societal function:

Whether gouging or dueling, ritual violence pervaded male culture and confirmed the most important masculine qualities, especially courage and loyalty. The threat of death was crucial. It helped unite rich and poor as men who prized physical courage above other manly traits and valued a man's willingness to die for his principles. ${ }^{117}$

In other words it helped to determine who were the 'real men' who could be counted upon in a crisis and who were the pretenders who were likely to run at the first sign of trouble.

This tendency toward violence often extended into a fierce competitiveness that found expression in overtly and frankly violent forms of recreation that included, hunting, gambling, horseback riding, prize-fighting, drinking, wrestling, and cock-fighting, among others. This competitiveness represented not only recreation to Southerners but also, like ritualized violence, provided the opportunity for vindication, a chance to show what they were 'made of' and that they 'measured up' as men. ${ }^{118}$

A good example of this was hunting. Hunting, a nearly exclusively male activity, was one of the most important of southern male rituals. According to Etcheson "Learning to hunt was an important step toward a boy's entrance into the male community ... even gaining permission to change ammunition from bird-shot to the more powerful buckshot was one of the

\footnotetext{
${ }^{116}$ Etcheson, “Manliness,” 64; Olsen, 172-3.

${ }^{117}$ Olsen, 174.

${ }^{118}$ Ownby, 24, 44-46, 49, 71 \& 81; Etcheson, "Manliness," 61 \& 64.
} 
last symbols of a boy's acceptance as a man."119 It was a chance to participate in an activity that had been a part of male culture since pre-history, the chance to risk life and limb in the pursuit of something vital, and the opportunity to prove one's mettle and one's mastery over nature by taking a life. It was also a chance to escape the bounds of female society and to be in the company of men, an activity whose very essence was that of violence.

Of even greater importance as a manhood ritual was cockfighting. ${ }^{120}$ It is no exaggeration to say that cockfighting was the ultimate male ritual. Not only was it the most popular sport of the antebellum South, one that drew fans from across the socio-economic spectrum and across racial lines, but it also featured many of the characteristics associated with proper male behavior. ${ }^{121}$ In some ways cock-fighting was the one institution in the South in which all males could participate. Southerners ascribed decidedly male characteristics to fighting birds. The most admired characteristic in a fighting cock was 'Gameness', what conditioning expert George Means of Concord, North Carolina, defined as "the power of will to stand punishment, and even death. The game fowl has this characteristic to an extent unequaled by any other living creature." Another writer characterized gameness as "that quality of spirit which sustains a fighting cock no matter how badly he may be punished."122

${ }^{119}$ Etcheson, "Manliness," 69.

${ }^{120}$ Ownby, 81 \& 71.

${ }^{121}$ Rozbicki points out that their passion for cockfights and other similar "manly" pastimes was one of the reasons why colonial gentry were considered unsophisticated poseurs, by English aristocrats, writing that "The colonists paid little heed to the fact that to members of European polite society such entertainments were distinctly ungenteel." One European observer asked "What wisdom can be learnt at a horse race or a cock-fight?" Rozbicki, 164.

${ }^{122}$ George W. Means, The Game Cock from the Shell to the Pit: A Comprehensive Treatise on Gameness: Selecting, Mating, Breeding, Walking and Conditioning (Gaffney S.C.: Grit and Steel, 1911) and R.A. McIntyre, 
Southerners praised a bird's ability to keep fighting after serious injury. One Virginian said of a particularly praiseworthy bird that it "made one of the gamest fights I ever saw. He was cut down on neck and coupled. ... I handled him and he got up and won out at the surprise of all at the pit side. I never saw a gamer cock in my life."123 On the other hand, as Ownby says,

A bird that ran from a fight-hacked, in the vernacular-was not merely a loser but a dishonored coward. . . . Losers received their share of praise if they were game. One Honea Path, South Carolina, breeder even suggested that defeat was acceptable by advertising, 'Every cock guaranteed to win his fight or die game,' and a . . Collettsville, North Carolina, fight left a cock dead but not dishonored. ${ }^{124}$

But cockfighting was also important for the way it reinforced the social hierarchy of the time. Gentlemen naturally owned the best birds and sponsored the biggest fights. This was an important means of reinforcing their leadership position in the community. This despite the fact that many scholars considered it to be the most democratic of sports because of its broad appeal. $^{125}$

But in addition to the inherent violence of activities like hunting and cockfighting, these activities could also indirectly inspire violence through the fierce competition they inspired. As Ownby relates: "Fueled by alcohol, the rivalry that accompanied almost all male recreations easily turned to violence, points of honor, long standing grudges, and petty disagreements could spark fiercely aggressive combat."126 This competitiveness, this need for vindication and

The Game Fowl: Its Origins and History> (Gaffney, S.C.: Grit and Steel, 1904( both quoted in Ownby, 78..

$$
\begin{aligned}
& { }^{123} \text { Olsen, 126; Ownby, 77, 78, } 79 . \\
& { }^{124} \text { Ownby, } 79 . \\
& { }^{125} \text { Ownby, 80-1. } \\
& { }^{126} \text { Ibid., } 53
\end{aligned}
$$


acceptance as a man, was also carried over to the polling place. In theory at least, voting was supposed to be an orderly, even legalistic process. Reality was often a different matter, one in which "Drunkenness, swearing, fighting, and bravado were the ruling ills that marred the day."127 As Christopher Olsen points out, aside from deciding important political issues, elections were events in which a candidate and his reputation were submitted to the judgement of the voting public. Elections were one of a number of ceremonies, including "court day" and militia musters, which helped to "unify the ruling caste, test the loyalty of newcomers, and reaffirm camaraderie among old friends."128

But while rituals such as cockfighting and electioneering provided opportunities for planter and non-planter to interact in a limited way, elections were of greater importance because they also helped to reinforce the existing social order. As Olsen also points out elections differed from these other rituals because of their competitive and public nature in which they were "laden with implications of class and power." ${ }^{129}$ Although southerners justified the slave system on the basis of promoting racial solidarity, a considerable degree of distrust and suspicion existed between planters and non-planters. Planters saw poor whites as ignorant, dirty, lazy, and depraved, while non-planters regarded their "self-appointed superiors" as arrogant, officious, and undemocratic. As Stephen Ash has written: "Aristocrats viewed most poor whites as a people without honor or respectability, a riffraff not amenable to patriarchal example or communal

\footnotetext{
${ }^{127}$ Olsen, 126.

${ }^{128}$ Ibid., 121.

${ }^{129}$ Ibid., 121.
} 
coercion and thus unreliable."130 One Confederate veteran, writing after the war, put it more bluntly: "The slaveholders thought they wer(sic) better than the Poor People."131 Such "riff-raff" were certainly not to be trusted to govern themselves in a responsible manner. Further aggravating planters' resentment toward the poorer classes and their suspicions regarding representative government were their fears over "the loss of status due to excessive democracy or the triumph of free labor principles in the South."132

For the Northern working classes perhaps the most important factor that influenced masculinity in the early nineteenth century was industrialization. ${ }^{133}$ As young men gradually moved from farmwork and headed to urban areas and factory work they carried with them an image of manhood defined as rugged individualism. But in time that image began to give way to a new 'industrialized' masculinity based upon middle-class notions of hard work and upward mobility. ${ }^{134}$ Mark C. Carnes and Clyde Griffen describe the process quite clearly: Industrialization, by substituting machinery for skilled labor and thereby facilitating the introduction of unskilled women and children to the factory, undermined traditional paths to manhood among skilled workers. The emergence of great corporations stabilized working conditions for many employees, pulling the fangs out of the dog-eat-dog world of Darwinian America. But this relative economic security also deprived men of "manly independence" and forced them to devise new conceptions of masculinity. ... The gradual advance of women into public life further obliged men to reexamine their relationship to work, to politics and government, and to marriage and the

${ }^{130}$ Edward E. Baptist, "Accidental Ethnography in an Antebellum Southern Newspaper: Snell's Homecoming Festival", $\underline{\text { JSH}}$, Vol. 84, No. 4 (March, 1998) 1356, 1362-4; Stephen V. Ash, "Poor Whites in the Occupied South, 1861-1865," JSH, Vol. 57, Number 1 (Feb. 1991), 42-3.

${ }^{131}$ S.P. Larkins, Civil War Veterans Questionnaires (Tennessee State Library and Archives, Nashville,

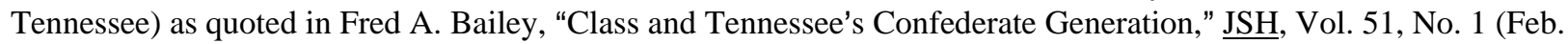
1985) 31-60..

${ }^{132}$ Crowther, 628.

${ }^{133}$ Elizabeth and Joseph Pleck in The American Man (Englewood Cliffs, N.J.: Prentice-Hall, 1980; See also Jack Nichols, Men's Liberation: A New Definition of Masculinity (New York, 1975); Joseph H. Pleck and Jack Sawyer, eds., Men and Masculinity (Englewood Cliffs, N.J., 1974); Eleanor Maccoby and Carol Jacklin, The Psychology of Sex Differences (Stanford: Stanford University Press, 1974); Perry Treadwell, "Biologic Influences on Masculinity," in Harry Brod, ed., The Making of Masculinities (Boston: Allen \& Unwin, 1987).

${ }^{134}$ Introduction, Meanings for Manhood: Constructions of Masculinity in Victorian America, Mark C. Carnes and Clyde Griffen ed., (Chicago: University of Chicago Press, 1990), 6-7. 
family. How male dominance remained essentially intact despite these many transformations is one of the central issues confronting scholars in this field. ${ }^{135}$

Peter Stearns similarly sees industrialization as having challenged "some key canons of manhood and made the fulfillment of others increasingly difficult." According to Stearns modernization influenced manhood by provoking an "increased rigidity" in male and female gender roles. it. In so doing there developed a version of masculinity "still recognizable today." 136

Mary P. Ryan describes quite clearly the impact of industrialization on male gender roles, characterizing them as shifting from "patriarchal authority" to "domestic affection." ${ }^{\text {137 }}$ Sean Wilentz, focusing on the Northeast, sees in these changes a transformation into three distinct categories of manhood--"patrician, artisan, and entrepreneurial"--as the "older ideologies of genteel patriarchy and artisan independence" were challenged by a new middle-class ideology of competitive individualism. ${ }^{138}$ David Leverenz sees in this transformation a battle for dominance between the old mercantile and landowning elites and the emergent class of entrepreneurial businessmen. Gradually "artisan norms of manhood" were displaced by a middle-class image of manhood defined in terms of "competitive individualism.".139

${ }^{135}$ Ibid.

${ }^{136}$ Stearns, Be A Man!, 1-2, 7-8; see also Lionel Tiger, Men in Groups, New York, 1969; Maureen Green, Fathering (NY, 1976); Ferdinand Zweig, Workers in an Affluent Society (NY, 1962).. 8.

${ }^{137}$ Mary P. Ryan, Cradle of the Middle Class: The Family in Oneida County, New York, 1790-1865 (Cambridge: Cambridge University Press, 1981); Introduction, Carnes and Griffen ed., 4.

${ }^{138}$ Sean Wilentz, Chants Democratic: New York City and the Rise of the American Working Class, 17881850 (New York: Oxford University Press, 1984).

${ }^{139}$ David Leverenz, Manhood and the American Renaissance (Ithaca, New York: Cornell University Press, 1989), 1-4; see also David G. Pugh, Sons of Liberty: The Masculine Mind in Nineteenth-Century America 
These "artisan norms of manhood and middle class expectations of upward mobility" were important for several reasons. In addition to providing an economic stimulus to the laboring class by promising that their hard work would eventually pay off, they were also essential to the process of political legitimization. According to Rowland Berthoff, material success was closely associated with a theory of republican citizenship that could be traced back to Aristotle, according to which the "virtuous republic" would be composed of a virtuous citizenry of economically independent males, who as property owners would be "independent of domination by any landlord, employer, or bribe-offering politician. ... free to devote his civic virtue to maintaining the public good." ${ }^{140}$

This theory, of course provided much of the philosophical basis for the JeffersonianDemocratic vision of the republic of small independent farmers. ${ }^{141}$ But by the mid-19th century this early ideal of citizens as independent land-owner had been redefined in compliance with the new capitalist realities. Whereas before most took it as gospel that, for the sake of republican virtue, it was necessary that the citizenry be composed of "independent, self-supporting" property-holders, it was now widely believed that any type of property, "even mercantile and industrial" property would suffice to maintain republican virtue. Even if a citizen did not own property, there were other characteristics, such as diligence and putting in a full day's work, that

(Westport, Conn.: Greenwood Press, 1983); Joseph H. Pleck, The Myth of Masculinity (Cambridge: MIT Press, 1981); The Making of Masculinities: The New Men's Studies, ed. Harry Brod (Boston: Allen \& Unwin, 1987).

${ }^{140}$ Rowland Berthoff, "Peasants and Artisans, Puritans and Republicans: Personal Liberty and Communal Equality in American History," JAH, Vol. 69, \# 3 (December 1982), 582.

${ }^{141}$ Nancy F. Cott, "Marriage and Women's Citizenship in the United States, 1830-1934," AHR, Vol. 103, No. 5 (December, 1998) 1453 . 
indicated that an individual could be trusted with the responsibilities of citizenship in "the virtuous commonwealth."142

As opposed to Europe, with its vestiges of feudalism, America represented the "last refuge for civil virtue"on Earth, where "self governing freeholders" could be assured that they, and their progeny, would be free from the dominance of a corrupt, landed aristocracy. And because of their selfless dedication to the defense of the nation, these self-reliant republicans could be counted upon to ensure the survival of "republicanism." Thus the very survival of democracy itself depended upon the presence of strong, aggressive, independent males for its defense. All of the qualities associated with republican virtue: self-reliance, simplicity in need and taste, decisiveness, and dedication to the public interest were all 'masculine qualities'. ${ }^{143}$ Thus, military service of some sort, either in the army or, more often, the local militia unit, became the obligation of every male who could carry a gun. ${ }^{144}$

If manhood was important to politics, politics was also important to manhood. As Jean Baker writes:

Universal white male suffrage implied that, since all men shared the chance to participate in elected politics, they possessed political equality. The right to vote was something important that men held in common, and something that differentiated them from women who did not have the right to vote. ${ }^{145}$

${ }^{142}$ Berthoff, "Peasants and Artisans," 585 .

${ }^{143}$ Ibid., 583; Nancy F. Cott, "Marriage and Women's Citizenship in the United States, 1830-1934,” $\underline{\text { AHR, }}$ Vol. 103, No. 5 (December, 1998), 1453; Baker, "Domestication of Politics," 624.

${ }^{144}$ Jean Baker, "From Belief into Culture: Republicanism in the Antebellum North," American Quarterly Vol. 37, No. 4, Republicanism in the History and Historiography of the United States, (Autumn, 1985$) 542$.

${ }^{145}$ Baker, "Domestication of Politics," 628. 
Election campaigns often celebrated symbols of masculinity, log cabins, military units, and used martial imagery: "parties were competing armies, elections were battles, and party workers were soldiers." ${ }^{146}$

Other definitions of manhood existed among the urban, working poor. For those crowded into impoverished neighborhoods, such as New York's notorious Five Points, where they were forced to compete for the most menial, low-paying jobs, violence was almost an inevitability. Here, emergent capitalism destroyed "a way of life that placed mutuality, comity, welfare, craft traditions, and independence" ahead of simple profits and replaced it with a way of life that emphasized productivity and regimentation and in which the worker was not a man, but an expendable cog in the machine. The nature of the work itself, while tedious, often required a great deal of physical brawn. It was also highly dangerous and ghastly, often fatal. Accidents became a nearly daily occurrence. Faced with such a grim reality many coped by assuming a callous attitude toward pain and suffering while others "gloried in bloody displays because high death rates, horrible accidents, and the specter of brutish poverty were a burden that bravado helped lighten." ${ }^{147}$

Many of these urban poor were Irish and German immigrants who, like the English before them, brought their traditional ideas of male behavior from the old country. ${ }^{148}$ These immigrant modalities of manhood combined with the dog-eat-dog realities of poverty, ethnic and racial hatreds, and the decline of traditional restraints such as religion and a stable family life to

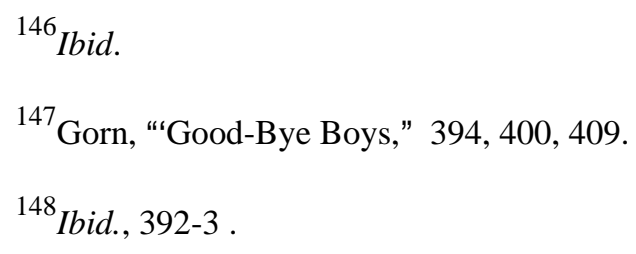


produce an exceedingly aggressive, hard-boiled form of manhood. Rather than "bourgeois" middle-class virtues like thrift, piety, industriousness, spirit of reform, domestic harmony, sober self-control and civic obligations, men adopted a set of masculine virtues that were more closely related to survival. ${ }^{149}$

Among the characteristics that were considered "manly" in this environment were heavy drinking, hard work, honor, the willingness to steal, engaging in such "manly" activities as billiards, cockfighting, frequenting boxing matches and brothels and most importantly the capacity and willingness to commit violence. ${ }^{150}$ It was not enough to merely possess the capacity for physical violence, or even the willingness to use it, to truly earn the respect of one's peers one had to actually commit a violent act. This act of "making one's bones," as a later generation would call it, was an important threshold on the road to manhood. Unless an individual had actually fought (and preferably killed) someone they could not really call themselves a man. In this urban jungle where gangs like the Dead Rabbits and Bowery B'hoys ruled the street, where "turf" was constantly being fought over, where control was maintained by force, violence was not only tolerated and accepted as a part of life, but was extolled as a positive good. ${ }^{151}$

In the Bowery or in the Five Points, no less than in Tidewater Virginia, gaining acceptance as a man within the community was vitally important. Maintaining one's reputation and standing, sense of honor, performed a vitally important social function. By winning the acceptance of the community, which might have meant acceptance within a gang, one

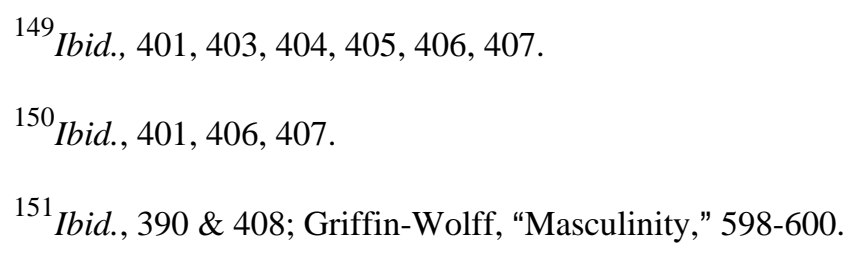


demonstrated their value to the community: that one could be relied upon to defend the community (or gang) in confrontations with police or with other gangs. And just as in the South, a man's reputation and his sense of honor were all important. ${ }^{152}$ As Eliot Gorn has written, the northern urban poor like southern 'aristocrats':

were acutely defensive of their honor; when violated it could be vindicated only through bloodshed. To accept an insult without response was to be shamed before one's equals; to back down from a real or perceived challenge meant losing face among the very people whose good opinion mattered most. ${ }^{153}$

The differences lay in the way that honor was maintained and disputes between individuals were settled. In both instances disputes over honor often led to violence, but the form that violence took in urban neighborhoods was decidedly less 'civilized.' In this urban jungle, where daily life was almost literally a struggle for survival, "physical" violence was the only acceptable means of resolving conflict. There was none of the code-duello with its elaborate rituals and aristocratic facade. These men made no pretense of being 'gentlemen.' With rare exceptions, street-fighting, unlike dueling, did not involve the use of firearms. It was a "manual" hand-to-hand affair. Shooting an opponent might indicate that one was a better shot, or perhaps lucky, but that did not make them a man. The whole point was to prove oneself through superior physical prowess; to physically 'conquer' and impose dominance through strength and power. ${ }^{154}$

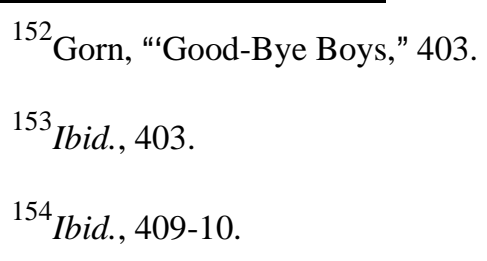


No one better embodied this aggressively violent form of manhood than the infamous William Poole, better known to friends and enemies alike as "Bill the Butcher." Indeed everything about Poole seemed to declare that he was a dangerous individual. Poole "gambled extravagantly, frequented bars and brothels, led a gang of toughs who terrorized voters on primary and election days, and revealed a streak of brutality in several vicious brawls." ${ }^{\text {155 }}$ Even Poole’s nickname of "Butcher Bill” carried strong masculine connotations. 'Butcher' implied a deadly reputation as one who was not only capable of killing ("butchery") but who was also quite willing to do so. Beyond that butchers were, of course, numbered among the ranks of urban working men. Also butchers, who made their living from dismembering the bodies of dead animals, symbolized primitive man's conquest of brutal nature. Poole certainly fit that profile. His reputation as a "deceitful, bloodthirsty, and unscrupulous" street brawler was well earned. At the time of his own murder in 1855, Poole himself was under indictment for assault with intent to commit murder. ${ }^{156}$

\section{--Western Masculinity--}

In the Old Northwest there developed a form of masculinity that combined elements of both the "honor-bound, aggressive" masculinity of the slave South with that of the mercantile Northeast. ${ }^{157}$ During the years following the Revolutionary War a large migration took place of

${ }^{155}$ Ibid., 392.

${ }^{156}$ Poole's murder at the hands of bare-knuckle boxer John Morrisey, on February 24, 1855, was significant for several reasons. It not only marked the end of his legendary, if nefarious, career (and life), but as Gorn observes, "Ironically, Poole's murder at gunpoint signaled the decline of grit and muscle as the sole source of power on the streets, for at midcentury, cheap concealable revolving pistols were being marketed on a mass basis." Ibid., 396, 398, 402, 409-410.

${ }^{157}$ Etcheson, "Manliness", 59-61 \& 65; Gregory S. Rose, "Hoosier Origins: The Nativity of Indiana's United States-Born Population in 1850," Indiana Magazine of History, 81 (Sept. 1985), 202-32, esp. 212.). 
"Upland Southerners" from Kentucky, Tennessee, Virginia and North Carolina into areas such as central and southern Illinois, Indiana and southern Ohio. As these migrants crossed the Ohio River into the Old Northwest they brought with them many 'southern' cultural traits such as racism, a "deep-seated antipathy toward the planters" and southern concepts of masculinity. ${ }^{158}$ Of course not only southern immigrants influenced masculinity in the Old Northwest. During the first half of the nineteenth century, as waves of Northeastern and New England settlers moved into the region in search of economic opportunity, they of course brought their own cultural traditions, including ideas about masculinity, with them. ${ }^{159}$ As these waves of settlers interacted it was only natural that their ideas about masculinity would also interact. ${ }^{160}$ Throughout the early nineteenth century the Old Northwest retained much of its frontier character including frontier hazards such as venomous snakes, bears, wolves, and hostile Indians. Even after an area was "settled" such factors as high infant mortality rates and a state of medicine so primitive that even a scraped knee could result in death made survival a very chancy thing. ${ }^{161}$ In such a wilderness environment, it was only to be expected that a form of masculinity would

\footnotetext{
${ }^{158}$ According to Etcheson: "The census of 1859 reports that forty-five percent of Hoosiers, sixty percent of Illinoisans, and thirty-eight percent of Ohioans had been born outside their states of residence. Furthermore, fortyfour percent of such Hoosiers, thirty-five percent of such Illinoisians, and nineteen percent of such Ohioans were reported born in the Upland South. Since the southerners were the first migrants into these states, these figures disguise an even larger southern presence because the children and grandchildren of southerners were counted as born in Ohio, Indiana, or Illinois. (Sources: U.S. Bureau of the Census, The Statistical History of the United States From Colonial Times to the Present (2 vols., Washington, DC, 1975), I, 27; U.S. Bureau of the Census, Mortality Statistics of the Seventh Census of the United States, 1850 (Washington, DC, 1855), 38-39 as cited in Etcheson, "Manlinesss," 60 \& 62

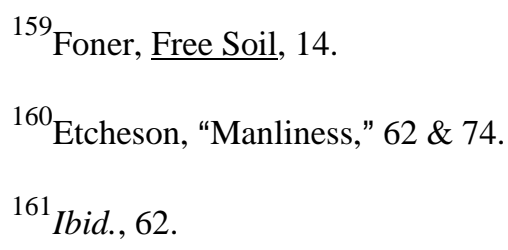


develop that had much in common with that of the South: a form of masculinity that emphasized physicality: physical strength and physical courage. ${ }^{162}$

And in fact Northwestern males shared many of the same standards for male behavior as their southern brethren, including such characteristics as brute strength, physical brawn, physical courage, survival skills, and indifference to pain and suffering both in themselves and in others, and a stoic aversion to emotionalism. In short, in the Northwest just as in the South, effeminacy was condemned; men were expected to be "bold, dynamic, athletic, hard-drinking", and handy with their fists. ${ }^{163}$

And in the Northwest, no less than in the South, candor; the courage to speak one's mind, was a highly prized quality in men. 'Real men' did not mince words nor did they use cryptic or ambivalent language that left the listener in doubt as to what was actually meant. 'Real men' spoke their minds; they said what they meant and meant what they said, whatever the consequences. ${ }^{164}$ This expectation was even higher for members of the political leadership class. In fact 'political candor' was seen as an absolute necessity to the survival of representative government. The problem was, to what criteria could one refer in order to judge whether a candidate was likely to act in the public interest or likely to be corrupt. Etcheson quotes one southern Ohio politico as saying:

It is impossible to know, correctly, the real character or patriotism of men whom we place in office, until we are taught by experience. Their corrupt principles, concealed under the mask of hypocrisy, may escape the public notice until they are elected. Then, if

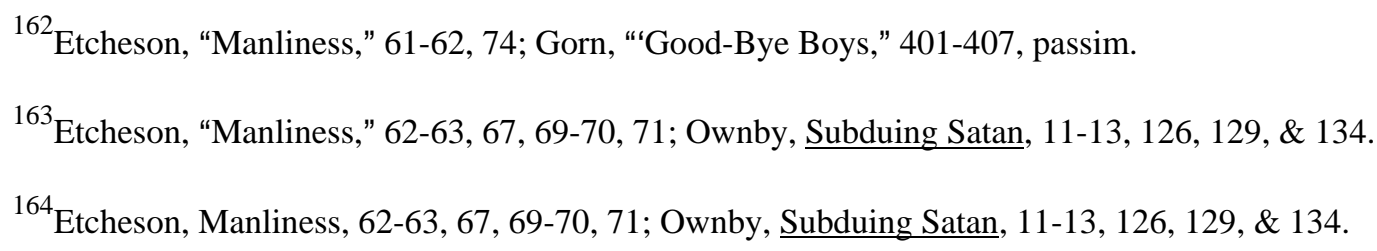


they are appointed to office without specification of time, they may throw off the mask, appear in their true character, and rule like arbitrary tyrants, while we shall be left to regret our folly in their election. ${ }^{165}$

Candor provided just such a criterion by which such judgements could be made. A candidate who spoke his mind, so the thinking went, "would not be inclined to intrigue or to become the tool of intriguers." Any candidates who failed to openly identify their motives should be regarded as either cowardly, corrupt, or both. ${ }^{166}$

Furthermore, in the Northwest, no less than in the South, recreation was an important indicator of masculinity. Northwestern males, just like southerners, often participated in such "manly" activities as drinking, swearing, fighting, wenching, wrestling, bare-knuckle brawling, and cockfighting. ${ }^{167}$ Recreation, in this situation, had an importance that extended beyond mere entertainment. Males in the Old Northwest, felt a very strong need to demonstrate that they measured up to community standards of manhood. By doing so, one proved one's value to the community and showed that one could be counted upon in a crisis. ${ }^{168}$ Often such tests of manhood involved some form of physical confrontation. ${ }^{169}$

Early on this may have been accomplished through actual combat and military heroics. But as the region became more settled following the Indian wars, other methods were adopted

${ }^{165}$ Etcheson, "Manliness," 68.

${ }^{166}$ Ibid., 67-69.

${ }^{167}$ Ownby, 11, 24, 44-46, 49, 81 \& 129; Crowther, "Holy Honor," 620 \& 624; Etcheson, "Manliness", 61; Richard Butsch, "Bowery B'hoys and Matinee Ladies: The Re-gendering of Nineteenth-Century American Theater Audiences," American Quarterly, Vol. 46, No. 3 (September, 1994) 374.

\footnotetext{
${ }^{168}$ Gorn, “'Good-Bye Boys,” 403; Olsen, 174.

${ }^{169}$ Etcheson, 62 \& 64; Ownby, 12-3; Olsen, 173.
} 
that included acts of physical strength and/or athleticism such as wrestling, prize-fighting or performing acts of physical prowess. ${ }^{170}$ Another way to win acceptance among one's male peers was to participate in 'manly' activities that might include gambling, horseback-riding, spinning yarns, pitching ‘quoits', drinking, swearing, cock-fighting, and hunting. ${ }^{171}$

Indeed, as male rituals, hunting and cockfighting were just as an important in the Northwest as they were in the South. The importance of hunting should need no explanation. In a wilderness environment the ability to hunt game was a necessary survival skill and might literally be the difference between life and death. And of course hunting also symbolized man's dominance over nature. Often just being considered a good shot was enough to win the approval of one's peers, even if one never faced any real danger. ${ }^{172}$ And cockfighting with its emphasis upon male characteristic such as 'gameness'--the ability to keep fighting even after suffering serious injury, drew fans from across the socio-economic spectrum and racial lines, just as it did in the South. ${ }^{173}$ This desire to gain acceptance among one's male peers often led to violence and sometimes even death. ${ }^{174}$ First, through the inherently violent nature of many "masculine" activities and through the fierce competitiveness that they promoted. ${ }^{175}$

${ }^{170}$ Etcheson, "Manliness," 59, 61-64; Ownby, 24, 44-46, 49, 71 \& 81.

${ }^{171}$ Etcheson, "Manliness," 59, 62-63.

${ }^{172}$ Ibid., 59, 62, 69.

${ }^{173}$ Ownby, 71 \& 81; Olsen, 126.

174 Ownby, 13-6, 62, 78-81; Etcheson, "Manliness," 6; Wyatt-Brown, 352-61, 370; McWhiney and Jamieson, Preface xv, 14-18; Isaacs, 95-104; Jordan, White Over Black, 28-40.

${ }^{175}$ Etcheson, "Manliness", 59, 62-63; Ownby, 53; Griffin-Wolff, "Masculinity," 598-600; Baker, "Domestication of Politics," 620. 
Finally, Midwesterners, especially those in rural communities, placed a very high value upon personal honor and were ever ready to defend their public reputation against even the slightest insult in order to maintain their good name and gain the acceptance and approval of their male peers and of the entire community. ${ }^{176}$ Northwestern males occasionally resorted to the code-duello, but usually their 'affairs of honor', like those among the urban working poor, were settled through less 'civilized’ forms of combat that included hair-pulling, kicking, biting, scratching, and eye-gouging. Even members of the political elite, like Stephen Douglas and Abraham Lincoln, found it necessary at various times to resort to brute force. Political violence was a pervasive element of both male culture and political culture in the Old Northwest. ${ }^{177}$ Immigrants from the Upland South were not alone in having influenced masculinity in the Old Northwest. Immigrants from east of the Appalachians, as they moved into the region, of course brought Northeastern, middle-class, market-oriented concepts about masculinity with them as well. ${ }^{178}$ As economic success became more and more identified with issues of masculinity, so did those qualities believed to bring about economic success such as hard work, honesty, diligence, self-discipline, frugality, punctuality, and sobriety. ${ }^{179}$

${ }^{176}$ Olsen, 172-173; Etcheson "Manliness", 62 -64; Crowther, "Holy Honor”, 620; Ownby, 12-13.

${ }^{177}$ Etcheson, "Manliness", 62, 64, \& 66; Olsen, 172-173.

${ }^{178}$ Etcheson, "Manliness", 59-62, 65; Gregory S. Rose, "Hoosier Origins: The Nativity of Indiana's United States-Born Population in 1850," Indiana Magazine of History, 81 (Sept. 1985), 202-32, esp. 212); Foner, Free Soil, 13-14; Baker, "From Belief into Culture," 538.

${ }^{179}$ Foner, Free Soil, 12-13, 23; Creighteon, "Male Breadwinner Family," 323; Ira Berlin, Herbert G. Gutman, "Natives and Immigrants, Freemen and Slaves: Urban Working Men in the Antebellum American South," AHR, Vol. 88, No. 5, (December, 1983) 1193. 
In fact, the capacity for hard work was just as important a measure of masculinity, in the Old Northwest, as was the capacity for violence. Indeed the ability to chop wood, split rails, plow fields, and perform any of a number of other back-breaking tasks, were just as necessary to survival as hunting game or fighting Indians. ${ }^{180}$ As this blending of cultures proceeded, economic success remained an important measure of masculinity, but as Eric Foner points out:

In the free labor outlook, the objective of social mobility was not great wealth, but the middle-class goal of economic independence. ... .A man who remained all his life dependent on wages for his livelihood appeared almost as unfree as the southern slave. There was nothing wrong, of course, with working for wages for a time, if the aim were to acquire enough money to start one's own farm or business. ${ }^{181}$

In the nineteenth century 'independence' carried a slightly different meaning than it does today. Independence meant more than just being free of parental authority. It meant being nondependent upon others, in other words, self-reliant. On the one hand being non-dependent meant that a man should not forever remain a member of the parental household, but should strike out on his own. Even in the modern world leaving home for the first time is still regarded as an important rite of passage. But in the nineteenth century it carried a greater significance. Independence meant accepting the responsibilities of the adult world. To the nineteenth century mind, independence meant establishing an independent household: taking a wife and fathering children. Perhaps most important was the acquisition of land which, in the nineteenth century was regarded as being the key not only to independence but to economic success as well. In

${ }^{180}$ It hardly needs to be stated that physical brawn and a muscular physique were also an important part of this image of masculinity. Etcheson, "Manliness", 62, 74.

${ }^{181}$ Foner, Free Soil, 16-17. 
short being a man meant becoming a responsible and productive member of the community and a virtuous republican. $^{182}$

If the key to manhood was economic and social independence and establishing an independent household then conversely, to never leave home was considered not only unmanly but a disgrace. It was the mark of an individual who was unwilling to accept adult responsibilities and who wished to forever remain a child. Such an individual was not worthy of respect. Not only could they not be relied upon in times of crisis, but they were also likely to become a burden to the community. Likewise, divorce, or worse yet abandonment, was similarly seen as unmanly and the act of a coward. Infidelity by one's spouse also cast suspicion upon one’s manhood. At the very least it indicated an inability to control one's wife. ${ }^{183}$

A final concept related to manhood in the antebellum Northwest, but which probably existed elsewhere, was the concept of 'gentlemanly' behavior. The concept of the 'gentleman' represented a higher form of masculinity: one that consisted of gentility, good breeding, good manners, integrity, refinement in dress and appearance and a sense of proper decorum in social situations. But being a gentleman involved more than just having good table-manners. As Nicole Etcheson writes, "the True Gentleman was candid, sincere, frank, intelligent and ever faithful to himself and others." ${ }^{184}$

${ }^{182}$ Introduction, Meanings for Manhood, Carnes and Griffen ed, 6-7; Baker, "Domestication of Politics," 624.

\footnotetext{
${ }^{183}$ Basch, "Marriage, Morals, and Politics," 892-894.

${ }^{184}$ Etcheson, “Manliness,” 70-71.
} 
An important point needs to be made concerning gentlemanly behavior. While financial success was an important prerequisite to being considered a gentleman, financial success alone did not guarantee acceptance from one's peers. In a time and in a region where labor was honored, the method by which financial success was achieved and the type of work done was crucial in winning acceptance. If one rose through the fruits of one's labors, through hard physical labor, diligence and fair dealing, success was considered honorable. However success acquired by dishonest means was not honorable. Even more dishonored were individuals who did not perform physical labor but who lived off the labors of others, such as bankers, land speculators, or worse yet, those who lived on inherited wealth. ${ }^{185}$ Furthermore, one had to take care not to become too gentlemanly. To do so might result in being labeled as a 'fop' or 'dandy. ${ }^{186}$

If economic success was an indicator of masculinity, then it followed that economic failure indicated a failure of masculinity. ${ }^{187}$ In the nineteenth century, economic success was almost universally regarded as being a result of individual effort: hard work, honesty, selfdiscipline, and diligence. Economic failure, rather than resulting from inequities within the system, was also attributed to individual effort or rather the lack thereof. Rather than bad luck, failure to advance in the world was the result of such vices as laziness, carelessness, dishonesty, intemperance, and extravagant spending. And since all of these factors were also indicative of

\footnotetext{
${ }^{185}$ Ibid., 75.

${ }^{186}$ Ibid., 75.

${ }^{187}$ Margadant, "Political Imaginary”, 1466; Creighteon, "Male Breadwinner Family,” 323.
} 
masculinity, failure in business was, by implication, a failure of manhood. ${ }^{188}$ The individual who failed to rise in the world was seen as less than a man. Even government efforts to protect the rights of working people were regarded as a threat to manhood. Reformer Samuel Gridley Howe said of a scheme to impose government limits on working hours: "It emasculates people to be protected in this way. Let them be used to protecting themselves."189

One can easily understand the appeal of the Free Soil movement, with its emphasis upon social mobility, the dignity of labor, entrepreneurial spirit, economic development, and its criticisms of southern slave society among residents of the Old Northwest. ${ }^{190}$ Indeed the Free Soil movement and its philosophical successor, the Republican Party, seemed tailor made to appeal to individuals grounded in an image of manhood based on aggression, economic success, self-reliance, and rugged individualism. ${ }^{191}$ It was a matter of political faith among free soil adherents that America was a land of almost boundless economic opportunity. Free Soilers and later Republicans routinely referred to Abraham Lincoln and other upwardly mobile young men as evidence of the truth of free soil doctrine that almost anyone, if they worked hard enough and were talented enough could rise as far as they desired. The self-made man was not just a political talking point, to them it was a very real possibility. ${ }^{192}$

${ }^{188}$ Foner, Free Soil, 23-24; Toby L. Ditz, "Shipwrecked; or Masculinity Imperiled: Mercantile Representations of Failure and the Gendered Self in Eighteenth-Century Philadelphia,” JAH, Vol. 81, No. 1 (June, 1994) 51-80. Ditz quotes a young Philadelphia merchant who, in 1798 "confided to his uncle that a recent series of business reversals had 'wholly unmanned' him.

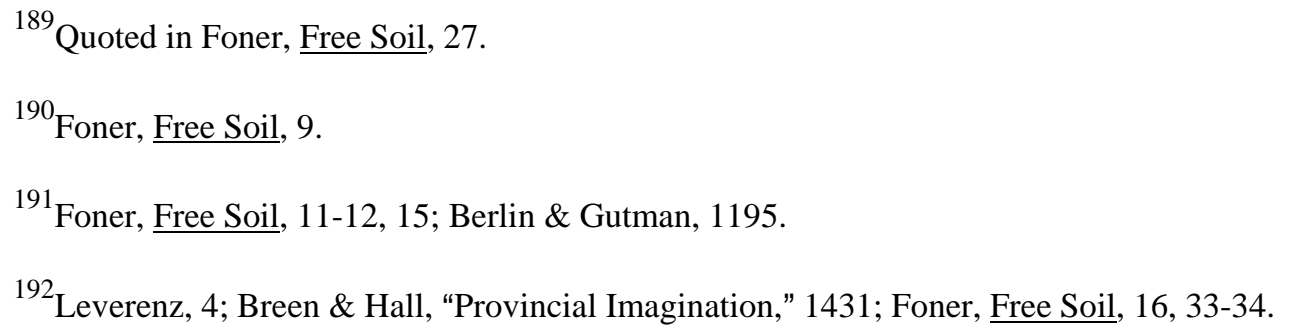


Southern slaveowners, in their attempts to expand slavery into the western territories, and possibly even into the Northern states, and in their efforts to block federal legislation aimed at funding internal improvements and protective tariffs that promoted economic development and greater opportunity, were threatening to destroy the Free Soil ideal of self-reliance and the selfmade man. Slave labor both degraded labor and lowered wages for free laborers who had to compete against unpaid slaves. Given the close association between economic success and masculinity it takes little imagination to see that by undermining economic expansion and opportunity through their obstructionism, southerners were symbolically at least attempting to emasculate these laboring men of the Northwest. To undermine their position as heads of households and chief breadwinner would endanger not only their status as citizens since the indigent were often disenfranchised, but also their paternalistic control over their dependent wives and children. ${ }^{193}$

\section{--Areas of Commonality-}

As distinctive as were Northern and Southern ideas of manhood, there were several points on which the two were in agreement. This is especially important given the fact that the similarities between North and South, especially in terms of masculinity, were as significant, if not more so, than their differences in bringing on the Civil War. Many of these similarities: the association of manhood with physical brawn, the importance of personal honor, the propensity

${ }^{193}$ Cott, "Marriage," 1452 \& 1453; Berthoff, "Peasants and Artisans," 582 \& 585; Berlin \& Gutman, 11761177. 
for violence, and the close association of masculinity with the political culture, have already been described at length and need not be restated here. ${ }^{194}$

Perhaps a more significant area of similarity between North and South involved the treatment of women. ${ }^{195}$ Women were socially marginalized to a remarkable degree in both the North (and especially the Northwest) and in the South. They enjoyed practically no legal status at all and were denied almost any vestige of political, social, and even economic independence. Except perhaps among abolitionists and other social reformers, women were generally treated as second-class citizens. Women had, almost literally, no legal identity of their own. A woman was either someone's wife, mother, daughter or sister. ${ }^{196}$

These restrictions were the end result of a process of domestication that began in the years following the War of Independence and which reached its peak in the Jacksonian Era. As the American economy evolved into a market-driven capitalist system, women's lives similarly evolved as they were relegated more and more to the role of household management. These changes were associated with the creation of the so-called "cult of domesticity." As women's domestic roles increased, their public roles nearly disappeared. They became increasingly subordinated to men and found themselves rendered increasingly powerless. Their political and

${ }^{194}$ Etcheson, "Manliness," 63-65 67-71, 72-74; Ownby, 78-81; see also Pugh, Sons of Liberty and. Rupert Wilkinson, American Tough: The Tough-Guy Tradition and American Character (New York: Harper and Row, 1984), p. 102.

${ }^{195}$ This is not to imply that there were not significant differences between North and South regarding the treatment of women, merely that there was also considerable agreement on this point.

${ }^{196}$ Cott, "Marriage," 1451-1452. 
economic rights were sharply curtailed, they were denied access to educational opportunities and to leadership roles in churches and generally converted into second class citizens. ${ }^{197}$

Wives were required to obey their husbands who controlled not only their persons but also their property. In fact a wife was almost literally her husband's property; she was required to surrender control of all her personal possessions and property to him at the time of marriage. She could not vote nor participate in the political process in any meaningful way. As a husband was required to support and protect his wife, so was a wife required to obey her husband. ${ }^{198}$ As Nancy F. Cott writes in The Bonds of Womanhood, Women's Sphere in New England, 17801835:

A married women had no legal existence apart from her husband's: she could not sue, contract, or even execute a will on her own; her person, estate, and wages became her husband's when she took his name. Divorce was possible--and, in the New England states, available to wives on the same terms as husbands--but rare. Women's public life generally was so minimal that if one addressed a mixed audience she was greeted with shock and hostility. No women voted, although all were subject to the laws. Those (unmarried or widowed) who held property had to submit to taxation without representation. ${ }^{199}$

${ }^{197}$ Aileen S. Kraditor Up from the Pedestal: Selected Writings in the History of American Feminism (Chicago: Quadrangle Books, 1968); Nancy F. Cott, The Bonds of Womanhood, "Woman's Sphere" in New England, 1780-1835 (New Haven: Yale University Press, 1977) 1-3, 5-8; Hernan R. Lantz, et al., "Pre-Industrial Patterns in the Colonial Family in America: A Content Analysis of Colonial Magazines," American Sociological Review 33 (1968): 413-26; Edward N. Shorter, The Making of the Modern Family (New York: Basic Books, 1975); Daniel S. Smith, "Parental Power and Marriage Patters-An Analysis of Historical Trends in Hingham, Massachusetts," Journal of Marriage and the Family 35 (1973): 419-28; Robert V. Well, "Family History and Demographic Transition," JSH, 9 (1975) 1-21, and "Quaker Marriage Patterns in a Colonial Perspective," William and Mary Quarterly, 3d ser., 29 (1972): 415-42.); Basch, 915; Crowther, 632.

${ }^{198}$ Cott writes, "There was no middle ground here: either one was independent and had the capacity to have dependents or one was dependent on someone else. The coverture of married women in the Anglo-American common law represented and perpetuated this polarity. In making a woman a wife, marriage removed from her and transferred to her husband her property and income, the very items that indicated free will. Cott, "Marriage and Women's Citizenship," 1451-1452.

${ }^{199}$ Cott, Bonds of Womanhood, 5. 
This change in women's political, social, and economic status was both predicated by, and helped to reinforce, many of the attitudes associated with the masculine culture at the time. Just as 'republican virtue' was often associated with masculinity, 'feminine' attributes such as "attraction to luxury, self-indulgence, timidity, dependence, passion" were similarly looked upon as corrupt and as threats to republicanism. ${ }^{200}$ Women were, therefore, a corrupting influence and as such had to be kept out of the political arena. On the other hand, the "cult of domesticity" was often justified on the grounds that women needed to be protected from the cruel and corrupt world outside of the home. And, since economic power was so closely associated with political power, it was essential that, in order to maintain the principle of white male citizenship (and dominance) that women be stripped of any trace of economic sovereignty. ${ }^{201}$

Women's lives thus came to be dominated by household chores, their opportunities for social contact more and more limited, and those primarily with other women. Even many members of the women's suffrage movement would have agreed with the old bromide that "a woman's place is in the home."202 It became a woman's role, as wife, as daughter, and especially as mother, to exert a "civilizing influence" on her husband and children. By exercising a moral influence over her family, specifically by raising civic-minded, virtuous sons, "republican

${ }^{200}$ Berthoff, "Peasants and Artisans," 583; Cott, "Marriage," 1453; Baker, "Domestication of Politics," 624; Jean Baker, "From Belief into Culture: Republicanism in the Antebellum North," American Quarterly Vol. 37, No. 4, Republicanism in the History and Historiography of the United States, (Autumn, 1985) 542.

${ }^{201}$ Cott, "Marriage," 1451.

${ }^{202}$ Baker, "Domestication of Politics," 620 \& 628-629; Karen, V. Hansen, “'Helped Put in a Quilt:' Men’s Work and Male Intimacy in Nineteenth Century New England," Gender and Society, Vol. 3, No. 3 (September, 1989)) 334. 
motherhood" insured national virtue and social order, and thereby the survival of the republic itself. $^{203}$

One of the few opportunities for women to participate in the public sphere, aside from supporting men, was to join one of the social reform movements, such as the women's suffrage movement, health reform, educational reform, or the antislavery movements. In the case of each of these reform movements, but especially with the antislavery movement, women were motivated, at least in part, by a desire to defend the family and domesticity against the ravages of slavery (or poverty or alcoholism or ignorance, etc). But even here women were not treated fully as equals. Their roles in the movement were always of an auxiliary nature; men were always in charge. $^{204}$

If there was any difference in the treatment accorded women in the South, compared to the North, the difference was one of degree and not of substance. Women in both sections were largely relegated to their 'separate spheres' and most northern males would have readily agreed with the southern minister who wrote:

When women go about haranguing promiscuous assemblies of men, lecturing in public on infidelity or religion or slavery or war and peace--when they meet together in organized bodies and pass resolutions about the 'rights of women' and claim for her a voice and vote in the appointment of civic rules, and in the government, she is stepping forth from her rightful sphere and becomes disgusting and unlovely, just in proportion as she assumes to be a man. ${ }^{205}$

${ }^{203}$ Baker, "Domestication of Politics," 620 \& 625; Jean Baker, "From Belief into Culture," 540.

${ }^{204}$ Cott, Bonds of Womanhood, 7-8; Baker, "Domestication of Politics," 625; Gillian Brown, "Getting in the Kitchen with Dinah: Domestic Politics in Uncle Tom's Cabin," American Quarterly, Vol. 56, No. 4, (Autumn, 1989) 503-523; Margadant, "Political Imaginary," 1471.

${ }^{205}$ George Howe, The Endowments, Position, and Education of Women, (Columbus, South Carolina: C.C. Morgan, 1850) 11-12, as quoted in McCurry, 112. 
Down South women were subjected to a form of patriarchal authority and marginalization at least as harsh as that found in the North, in fact probably more so. Among the poorer classes, the family patriarch had almost unlimited authority over the dependents in his household, whether they were women, children, or a slave. Women, thus, had little choice but to submit to patriarchal authority in virtually all things. ${ }^{206}$ Southern patriarchs also had absolute control of their dependents' labor. What that meant in practical terms is that often yeoman women, in addition to their household chores, also had to work in the fields "like negroes."207

If women's lives in the South were more restrictive than in the North, it was undoubtedly due to the presence of slavery. This is hardly surprising given the fact that one of the most fundamental justifications for the slave system was the protection of white women from the alleged horrors of miscegenation (or race-mixing) and the preservation of racial purity. ${ }^{208}$ By the early nineteenth century, Southerners (and Northerners for that matter) developed an almost paranoid preoccupation with miscegenation. Racial stereotypes of the time portrayed black males as passionate, libido-driven primitives who were barely able to contain their hunger for white women. The only way to control blacks was to keep them in chains. ${ }^{209}$ As William Freehling phrases it:

\footnotetext{
${ }^{206}$ McCurry, 84, 85.

${ }^{207}$ Ibid., 79, 81-83.

${ }^{208}$ It is worth noting that "racial purity" in this context did not apply to male slaveholders actions toward

${ }^{209}$ Wertenbaker, 33, 104-5; Wyatt-Brown, 25; Morgan, 375-78; Sydnor, Gentleman Freeholders, 1-4;
} their female slaves.. Freehling, 55-57. 
enslaving blacks kept white women pure. Slavery protected fair-skinned damsels from defilement by rape, from degradation by seduction, from despoilment by interracial marriage. With purity guaranteed, mistresses could be moral queen of the home. ${ }^{210}$

But, as Julia Cherry Spruill points out, while marriage may have been a "Covenant of God" and slavery may have been an institution designed to protect white women from "defilement, degradation and despoilment" neither did much to restrain white masters who regularly indulged in sins of the flesh with female slaves who had little choice but to submit. ${ }^{211}$ In one of the most famous passages of her diary, South Carolina matron Mary Boykin Chesnut excoriated the Great White Fathers for both their indiscretions and their hypocrisy:

God forgive us, but ours is a monstrous system and wrong and iniquity. . . . Like the patriarchs of old our men live all in one house with their wives and their concubines, and the mulattoes one sees in every family exactly resemble the white children . . . Mr. Harris said it was so patriarchal. So it is, flocks and herds and slaves--and wife Leah does not suffice. Rachel must be added, if not married. And all the time they seem to think themselves patterns--models of husbands and fathers. ${ }^{212}$

Perhaps as a way of deflecting their wives' criticism or to assuage their own guilty consciences planters began to "elevate" planter women, venerating them to a degree comparable to that of the European aristocracy. ${ }^{213}$ "Plantation Ladies" did not labor in the field like negroes and non-planter women, and for the very wealthiest even household chores were considered

${ }^{210}$ Freehling, 56.

${ }^{211}$ Julia Cherry Spruill, Women's Life \& Work in the Southern Colonies, (New York: W.W. Norton \& Company, 1972), 136, 172, 174, 176-7. 31.

${ }^{212}$ C. Vann Woodward ed., Mary Chesnut's Civil War, (New Haven, Conn.: Yale University Press, 1981),

$$
{ }^{213} \text { McCurry, } 217 .
$$


beneath them. ${ }^{214}$ Thus 'freed' from the drudgery of labor, women of the planter class spent their days in an endless series of social visits, but only with the "Right Sort."215 But at the same time, the more women were 'elevated' by slavery, "placed on a pedestal" as the saying went, the more isolated and restrictive their lives became. Slavery may have freed them from manual labor, but in almost every other sense of the word it served to tighten the bonds of patriarchal authority. ${ }^{216}$

Another important area of similarity between northern and southern males was the tendency to see themselves as representing the "embodiment of manhood" and to denigrate their counterparts as less than manly. To northerners, the white south was a relic from the medieval past. There were only two classes in the South: At the top were the arrogant, oligarchical slaveholding planter aristocrats. The planters, despite their pretensions of "Southern Chivalry" were viewed with contempt by northerners as effete, luxury-loving "Cotton snobs." Since they did not earn their living by the sweat of their brows but off of the labor of slaves, they could never be considered "real men." Prideful and vain, used to having their every command obeyed and their every whim catered to by their slaves, the planters were viewed by many in the North as being full of bluster, but when confronted directly they always backed down. ${ }^{217}$

Below the planters were the mass of ignorant, poor whites. Regarded by Northerners as "oppressed, benighted and degraded by the stigma attached to manual labor in the slave South,"

${ }^{214}$ Ibid., 83.

${ }^{215}$ McCurry, 125, 128-129; Freehling, 55-57.

${ }^{216}$ McCurry, 212, 214, 216-217. See also Ann Firor Scott, The Southern Lady: From Pedestal to Politics, 1830-1930 (Chicago: University of Chicago Press, 1970); Catherine Clinton, The Plantation Mistress: Women's World in the Old South (New York: Pantheon Books, 1982).

${ }^{217}$ Ash, "Poor Whites," 40. 
these poor white Southerners were only nominally better off than slaves, if they were better off than slaves. Although they represented the vast majority of the white population of the South, these "crackers" were held in subjugation by a tiny planter class that played upon their racial prejudices in order to dupe them into supporting a system that ruthlessly exploited them. ${ }^{218}$ By the eve of the Civil War, Northerners came to view this large population of poor whites as having grown restless and resentful under the rule of the planter aristocrats. "This silent majority, it was presumed, anxiously awaited the liberating armies of the North."219

\footnotetext{
${ }^{218}$ Ibid., 40.

${ }^{219}$ Ibid., 40.
} 


\section{CHAPTER 3}

\section{PRESTON BROOKS:}

Preston Brooks is the most obscure of the individuals under consideration. This is due to the dearth of credible information concerning his life. The few primary sources that exist are fragmentary and scattered. Secondary sources are hard to come by and not entirely reliable, many simply parrot erroneous information gleaned from other secondary sources. In an October, 1978, article published in South Carolina Historical Magazine Robert McNeil Mathis decried the lack of serious scholarship on Brooks. The advent, in recent years, of the internet and electronic resources such as the University of Michigan's Making of America site and Furman University’s Nineteenth Century Primary Documents project have made possible a more complete portrait of Brooks than at any time since perhaps his death. Still it is important to point out that there are certain aspects of Brooks's life that may never be known.

Given the fact that the details of Brooks's life are not as well known as those of Sumner, Davis, and Lincoln, a more complete biography of Brooks is justified. Preston Smith Brooks was born August 6, 1819, in the village of Edgefield Court House in what was then known as the Edgefield District of South Carolina. ${ }^{220}$ His father, Whitfield Brooks, Sr. who was described as "a man of science, of liberal education, and polished manners," had been born in Newberry District, and some time after his birth the Brooks family relocated to a spot near Big Creek in Edgefield

\footnotetext{
220“'Art. V.-Hon. Preston S. Brooks-Speeches of the Honorable Preston S. Brooks, and Proceedings of Congress on the occasion of his death, Southern Quarterly Review (February 1857) Vol. 2; No. 2, pg. 349. accessed

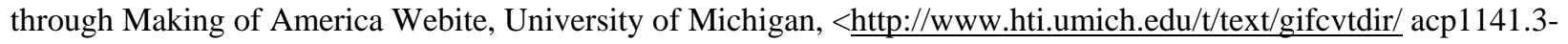
02.002/03480348.tifs.gif> (hereafter "Speeches").
} 
District. $^{221}$ Whitfield Brooks attended South Carolina College (now the University of South Carolina) where he graduated with honors in 1812. ${ }^{222}$ After college Whitfield Brooks studied law, was admitted to the bar in 1815, and was appointed Equity Commissioner for Edgefield District, a position he held for the next eighteen years until poor health forced him to resign. Whitfield Brooks also served at least one term in the state legislature. ${ }^{223}$

In June, 1818, Whitfield Brooks married Mary Parsons Carroll of Charleston and together they had five children. ${ }^{224}$ In addition to Preston, the Brooks children included James Carroll Brooks (born 1820 or 1821), Ellen Sophia Brooks (born circa 1820), John Hampden Brooks (probably born 1823) and Whitfield Butler Brooks (also called Whitfield Brooks Jr. and probably born in 1825). ${ }^{225}$

\footnotetext{
${ }^{221}$ Antebellum South Carolina place names can be a source of confusion. Several locations associated with Preston Brooks's youth have either undergone name changes, been re-configured or disappeared altogether. The area which at the time comprised the "Edgefield District" has since been divided into Edgefield and Saluda. Big Creek, then part of "Edgefield District" now lies on the Northern edge of Saluda county. Ibid.

${ }^{222}$ Preston Brooks was apparently named for one of Whitfield's college classmates, William Preston. John Belton O'Neall, "Whitfield Brooks" Biographical sketches of the bench and bar of South Carolina, 473, accessed through Making of America Webite, University of Michigan, <http://www.hti.umich.edu>.

${ }^{223}$ Ibid.

${ }^{224}$ Ibid.

${ }^{225}$ Because South Carolina did not require the issuance of birth or death certificates until the early twentieth century, affixing dates of birth is an extremely tricky business. One is often forced to rely upon second hand information which is not always reliable. In the case of Brooks and his siblings, according to one, not very credible, source Brooks had another sister named Nancy, but as she is not mentioned anywhere else the claim cannot be accepted at face value. Another source lists his brother Whitfield as being born in 1817; another says "between 1813 and 1840." In his profile of Whitfield Brooks Sr. written for his Biographical sketches of the bench and bar of South Carolina, John Belton O'Neall listed the younger Whitfield as being twenty-two years old at the time of his death in 1847, which would make his year of birth, 1825. Since O'Neall was acquainted with the Brooks family his date of 1825 must be given weight This same problem of indeterminate birth records also arises in discussing Brooks's own children. O'Neall, 474; "Speeches," 348-349; Brian D. McKnight, "Preston Brooks" Encyclopedia of the American Civil War, 288-9; William L. Barney, "Brooks, Preston Smith," American National Biography (John A. Garrity, Mark C. Carnes, General Editors) Oxford University Press, New York, 1999, 625; Representative Lawrence Keitt, "Eulogy of Preston S. Brooks," Congressional Globe, $34^{\text {th }}$ Congress, Third Session, Wednesday, January 29, 1857,
} 
Brooks and his siblings could claim a most impressive pedigree, one that included some of the most distinguished families, not only in South Carolina, but in the entire South. His mother's family, the Carrolls, were numbered among Charleston's planter elite. His paternal grandfather and family patriarch, Zachariah Smith Brooks was remembered not only as a successful planter but also as a hero of the Revolutionary War. ${ }^{226}$ But more than that Zachariah Brooks was fortunate enough to marry into one of the most powerful families in the antebellum South, the Butlers. The Butler clan, which included numerous military and political leaders, traced its origins as far back as the earliest colonial period and even claimed familial ties to the British nobility. By the nineteenth century, the Butlers had amassed an enviable record of achievement and service and had produced countless military and political leaders.

Zachariah's wife, (and Preston Brooks's grandmother) Elizabeth Butler Brooks, was the sister of General William Butler who became a near legendary figure for his own Revolutionary War service. $^{227}$ General Butler was the father of Andrew Pickens Butler, who became a successful lawyer, judge, and later a United States Senator. While serving as Senator Andrew Butler was the target of Charles Sumner's vitriol in the "Crime Against Kansas" speech that provoked Brooks, as Butler's cousin, to attack Sumner. ${ }^{228}$ Another cousin of both Brooks and Butler, was famed Alamo defender James Butler Bonham. ${ }^{229}$

500.

226“Speeches," 348-349.

${ }^{227}$ Genealogical information accessed through the Brooks family genealogical website, The Brooks Historian, Home of the Brooks Genealogy, Historical Archive, and Reference Library, <http://brookshistorian.org/ bbrooks/public.html> accessed 7 July 2005 (hereafter (Brooks Historian); "Speeches,” 348-349.

${ }^{228}$ One of the main misconceptions about Brooks concerns his relationship to Butler. Most sources incorrectly identify Butler as Brooks's Uncle. In fact Butler and Preston Brook's father, Whitfield Brooks, Sr. were 
An important component of Preston Brooks's preparation for his rightful place as a member of the ruling planter elite was his education. Like most sons of the planter class, Brooks attended a private academy, in this case the Moses Waddell School in Willington, South Carolina. He may have also attended public schools in Edgefield. ${ }^{230}$ Later, like his father, Preston Brooks attended South Carolina College where his roommate was future Texas Senator Lewis T. Wigfall. ${ }^{231}$

At college Brooks earned a reputation as being a capable student, "a favorite with the ladies," and for engaging in rowdy behavior that almost led to his expulsion on more than one occasion. In a pattern of behavior that should be all-too-familiar to modern professors, Brooks often preferred to spend his time at the local tavern rather than in class or studying. The fact that he was able to do this, and still maintain acceptable grades, only served to infuriate his professors. ${ }^{232}$ On one occasion Brooks became involved in a shoving match with another student over the disputed results of a student election. What might otherwise be considered a minor incident is interesting for two reasons: the first was Brooks's refusal to accept a challenge to a

first cousins, which makes he and Preston Brooks first cousins once removed. Brooks Historian.

${ }^{229}$ Ibid.

${ }^{230}$ There is some disagreement regarding how much time Brooks spent at the Waddell School. Some sources say that Brooks received most, if not all, of his education there while others state that he spent only 'a brief period" at the academy. As the school is no longer operating there is probably no way of knowing for sure. "Speeches," 349; Barney, 625.

${ }^{231}$ McKnight, 288; Barney, 625; Eulogy of Preston S. Brooks, Congressional Globe, $34^{\text {th }}$ Congress, Third Session, Wednesday, January 29, 1857, 500.

${ }^{232}$ Robert Neil Mathis, "Preston Smith Brooks: The Man And His Image," $\underline{\text { South Carolina Historical }}$ Magazine October, 1978, 299. 
duel. The second reason was the fact that Brooks's antagonist was expelled while Brooks received only a temporary suspension. ${ }^{233}$

Brooks left South Carolina College in 1839 under somewhat irregular circumstances. Mathis states that Brooks, just before graduation, became involved in a serious confrontation with Columbia, South Carolina, authorities after his brother was arrested. According to Mathis, Brooks, outraged at what he regarded as his brother's "ignominious treatment" by his jailers, armed himself with a "brace of pistols" and ran to the jail, presumably with the intention of breaking his brother out. While the episode ended without bloodshed--Brooks was disarmed "without incident"--still it proved to be the last straw for the faculty who, fed up with Brooks's rowdyism, withheld his degree. Mathis leaves the matter at that. ${ }^{234}$

What happened next is a matter of dispute and it is not entirely clear if Brooks actually graduated or not. According to most secondary sources Brooks never received his degree. ${ }^{235}$ But South Carolina Representative Lawrence Keitt, who served with Brooks in Congress and who knew him well, in his eulogy of Brooks maintained that Brooks did graduate from South Carolina College and even received "one of its distinctions," an opinion echoed by the Southern Quarterly Review in its eulogy of Brooks. ${ }^{236}$ While the matter remains uncertain the fact that

\footnotetext{
${ }^{233}$ The details of this incident are so sketchy that it is difficult to pinpoint exactly why Brooks refused the challenge. However, given the nature of the code-duello and the perception that it was practiced only by gentlemen, the likely reason was that Brooks considered his antagonist to be his social inferior. This may also help explain why Brooks was not expelled. Robert Mathis believes that Brooks's record of schoalrship saved him. That may be true but the fact that Brooks refused to accept the challenge to a duel may have also figured in the administration's decision. Also one cannot ignore the possibility that Brooks's social status and his powerful family connections may have also played a role. Mathis, "Image," 299.

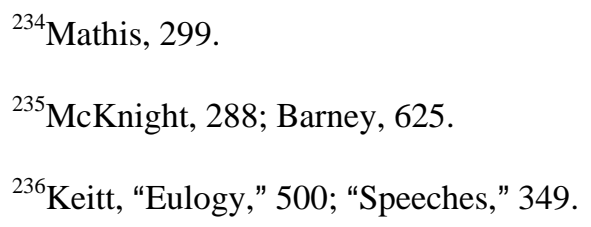


Brooks later studied law, although lawyers at the time were not required to be college graduates, seems to indicate that Brooks probably received his degree. In any event, Brooks passed the bar exam in May, 1843, and opened an office in Edgefield. ${ }^{237}$

During this same period, relations between Brooks and his former roommate, Lewis T. Wigfall, began to deteriorate. The two men became engaged in a bitter political dispute that eventually led them to the dueling ground. ${ }^{238}$ The roots of the duel with Wigfall can be traced to the gubernatorial election of 1840 in which Preston and Whitfield Brooks backed James Hammond. During the campaign Wigfall, who backed Hammond's opponent, made some rather unflattering remarks about Hammond in the press. After the election, which Hammond won, Wigfall, angry and frustrated, turned his attention to Whitfield Brooks and referred to him as a "scoundrel and a coward." That brought a challenge from Preston Brooks. ${ }^{239}$ Brooks and Wigfall met on the field of honor probably in June 1841. The encounter ended in bloodshed. Although neither party was killed, both men suffered serious injuries. Brooks and Wigfall missed with their first shot, but both found the mark with their second. Brooks struck Wigfall in the leg and Wigfall, in turn, hit Brooks in the hip, inflicting a painful wound that required Brooks to walk with a cane thereafter. ${ }^{240}$

${ }^{237}$ McKnight, 288-9; Barney, 625; Keitt, “Eulogy,” 500; “Speeches,” 349.

${ }^{238}$ McKnight, 288-9; Barney, 625; Mathis, “Image,” 300.

${ }^{239}$ Wigfall had already killed Brooks's cousin, Thomas Bird, in a duel over this same matter. It may have been as much to avenge Bird's death, as for the insult his father, that Brooks challenged Wigfall to a duel. McKnight, 288-289; Barney, 625; Mathis, "Image," 300.

${ }^{240}$ Brooks, who carried the bullet in his hip for the rest of his life, used this same cane to attack Charles Sumner fifteen years later. McKnight, 288-9; Barney, 625; Mathis, "Image," 300. 
Meanwhile, earlier that year, on March 11, 1841, Preston Smith Brooks married Caroline Harper Means in Buckhead, Fairfield County, in a ceremony conducted by Reverend R.C. Ketchem. Details regarding the courtship and how the two met are unknown, but the marriage itself was destined to be a short one. Caroline died a little more than a year later on June 28, 1842, at her parents' home, along with the couple's infant son, Whitfield named for his paternal grandfather. $^{241}$ Brooks remarried in either 1843 or 1845, this time to Caroline's cousin, Martha C. Means. Together Preston and Martha had four children: Sallie Means Brooks (born 1847); Rosa Brooks (born sometime between 1847 and 1851) Caroline Harper Brooks (probably born in 1849) and Preston Smith Brooks, Jr. (born August, 1854). ${ }^{242}$

In the meantime, Brooks's support of South Carolina Governor James Hammond paid off when Hammond, in 1842, appointed Brooks as his "aide-de-camp."243 Brooks proved a capable aide and won praise from Hammond for his efforts. Brooks performed what was perhaps his most valuable service to the governor in December 1844 when Hammond sent him to Charleston to deal with a difficult situation involving an abolitionist lawyer named James Doar who had been sent by the Massachusetts legislature to investigate the treatment of Negro seamen by Charleston law enforcement officials. In a statement to Charleston and South Carolina officials, published in local newspapers, Doar stated that his reason for being in South Carolina was to guard against Massachusetts citizens (i.e. blacks) being "imprisoned without the allegation of a

\footnotetext{
${ }^{241}$ The exact cause of Caroline's death is not known. Barney, 625; Edgefield (S.C.) Advertiser, "Marriages, Centennial Edition, (1936) cited in Brooks Family Bulletin, Volume II, No. 3, July 1973, pg. 50, access through Brooks Historian..

${ }^{242}$ Barney, 625.

${ }^{243}$ McKnight, 288-9; Mathis, “Image,” 300.
} 
crime." To carry out this 'mission' Doar was authorized by the Massachusetts legislature to bring suit on behalf of any of her citizens so imprisoned. ${ }^{244}$

To the Charlestonians, however, Doar's mission had a more sinister aim. His real reason for being in Charleston was not to defend the rights of seamen but to engage in "slave stealing." When angry citizens demanded that the government take action, the state legislature passed several resolutions that demanded, among other things, that Governor Hammond, "expel from our Territory, the said Agent (Doar) after a due notice to depart." ${ }^{245}$ Several newspapers, the Charleston Courier and Charleston Enquirer to name two, even went so far as to demand that Hammond call out the militia in order to evict Doar. ${ }^{246}$

Hammond, wisely, instead dispatched Brooks to diffuse the potentially explosive situation. The Carolinians were hopping mad and ready to form a lynching party at any moment. Doar, for his part, showed no signs of backing down. Given his rowdy past Brooks may not have seemed the best choice to deal with such a delicate situation, yet he handled the matter with tact and diplomacy. After meeting with Doar and convincing him that he could not hope to prevail in the South Carolina courts, Brooks managed to secure Doar's withdrawal from the city by simply "taking the old gentleman by the hand and conducting him aboard the Wilmington

\footnotetext{
${ }^{244}$ The source of this controversy was a law that South Carolina had passed in 1822, in response to the belief that sailors from Santo Domingo had aided and abetted Denmark Vesey and his followers, which required that all Black seamen, even those on foreign vessels, be jailed while their ships were docked in Charleston. Supreme Court Justice William Johnson, a Carolinian by birth, declared the law unconstitutional but South Carolina authorities continued to enforce it, despite the fact that such jailings violated international treaty as well as the Constitution. Mathis, "Image," 300; Charleston Mercury December 6, 1844, 2; Freehling, 254.

${ }^{245}$ Charleston Mercury, December 7, 1844, 2.

${ }^{246}$ Ibid.
} 
Boat."247 When Hammond's term expired in January 1845, Brooks threw his own hat into the political ring and in November won a seat in the South Carolina House of Representatives. After serving a single two-year term, Brooks returned to his law practice. ${ }^{248}$

Brooks's return to private life was interrupted by the War with Mexico. Brooks, like other young men his age, all across the North and South, joined the rush to the colors. Brooks raised a company of 100 volunteers among his kinsmen and neighbors in Edgefield, including his brother Whitfield, who dubbed themselves the "Ninety-Six Boys." ${ }^{249}$ As was the custom at the time, the company elected their officers and Brooks was chosen as Captain; other company officers included First Lieutenant Moragne, and Second Lieutenants Joseph Abney and David Adams. ${ }^{250}$ Within days Brooks's company had joined the regiment known as the "Palmetto Guards” (officially the South Carolina Volunteers) as Company 'D.' The Commanding Officer of the Palmetto Guards was Brooks's cousin, Pierce Mason Butler. The Palmetto Guards were mustered into service in December, 1846 and, together with the New York Volunteers, were assigned to Shields's Brigade of General John A. Quitman's Division. ${ }^{251}$

${ }^{247}$ Ibid.

248“"Speeches," 350; Mathis, "Image," 301.

${ }^{249}$ This name did not refer to their numbers but was apparently a reference to the Revolutionary War outpost of "Fort 96" located about fifty miles north of Edgefield and today designated as "96 National Historic Site."

${ }^{250}$ Barney, 625; Keitt, “Eulogy,” 500; “Speeches,” 368-369.

${ }^{251} 30^{\text {th }}$ Congress, $1^{\text {st }}$ Session, Executive Document No. 8: Message from the President. Daily American

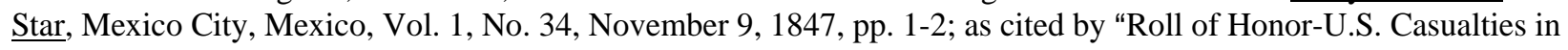
the Battles of Churubusco and Contrera, PART THREE" Descendants of Mexican War Veterans, Copyright, 19962006, < http://www.dmwv.org/honroing/chucon3.htm>; Senator John A Quitman, "Eulogy of Preston S. Brooks," Congressional Globe, $34^{\text {th }}$ Congress, Third Session, Wednesday, January 29, 1857, 500; Robert Selph Henry, The Story of the Mexican War (New York: The Bobbs-Merrill Co., 1950)201, 258 \& 511. 
When Brooks returned from the war, his father's poor health forced him to abandon the legal profession and devote himself full time to agriculture. Whitfield Brooks Sr., whose health was not good to begin with, was so upset by the death of his youngest son, Whitfield Jr., in Mexico, that he began to deteriorate rapidly. In the Spring of 1849, Whitfield Sr. permanently relocated to his plantation "Roseland" and left the residence in Edgefield to Preston and his family. With his father no longer able to manage "Roseland," Preston assumed more and more of the managerial responsibilities in which, according to Keitt, he was "eminently successful." 252

After his father died on December 28, 1851, Preston Brooks began to play a more active role in state Democratic politics. ${ }^{253}$ In 1852, he became involved in an effort among South Carolina Democrats, including his cousin Andrew Butler, to block a movement among some of their Carolina Democrats who, fearing that the party might nominate a presidential candidate unfriendly to Southern interests, were trying to break away from the national party organization. In the end, Brooks and his colleagues successfully blocked the so-called 'Irreconciliables' and

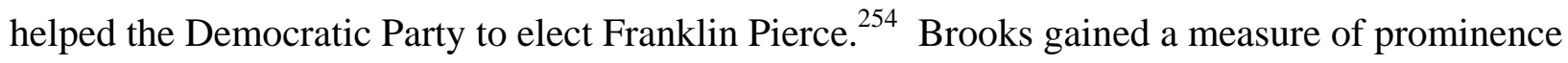
among South Carolina Democrats, so much so that when Congressman Burt, who represented Brooks's home district, declined reelection, Brooks was elected in his place. ${ }^{255}$ On March 15, 1853, Brooks took his seat in Congress as the representative of the Fourth Congressional District

\footnotetext{
${ }^{252}$ Keitt, "Eulogy," 500; "Speeches,” 349.

${ }^{253}$ O’Neall, "Whitfield Brooks," 473.

${ }^{254}$ Mathis, “Image,” 301-302.

${ }^{255}$ McKnight, 288-9; Barney, 625; Keitt, "Eulogy”, 500; “Speeches,” 350.
} 
of South Carolina, the same district that had once elected John C. Calhoun. ${ }^{256}$ As the man who occupied the seat once held by the great Calhoun, Brooks faced high expectations. As South Carolina's Senator Josiah Evans said in his eulogy of Brooks:

The man who succeeded such men (as Calhoun) had an arduous duty to perform to fulfill the expectations of those who had sent him. In the discharge of the duties of his station he was modest, unobtrusive, yet, when the occasion required, he spoke his sentiment with eloquence, openness, candor and sincereity(sic), which won him the respect of all-even those who were not convinced by his argument. ${ }^{257}$

Considering how much was expected of him, Brooks proved a rather lackluster

Congressman. During his first term Brooks introduced no major legislation. In fact it would be a full year before Brooks made his first speech in Congress, on March 15, 1854, when he spoke in favor of the Kansas-Nebraska Act. While the Southern Quarterly Review later characterized this speech as a "triumphant refutation" of Northern objections to the bill, in fact it was a rather pedestrian effort that contained little that was new and did little more than restate standard Southern dogma--that slavery was sanctioned by the Bible and the Constitution, benefited the "general good of the Country" and guaranteed humanitarian treatment of the slaves themselves. $^{258}$

Brooks's speech, not surprisingly, failed to garner much attention in the press or among his Congressional colleagues. It was until June that Brooks gave his next speech, this one on the

\footnotetext{
${ }^{256}$ In addition to Calhoun, the same seat had also been held by Robert Goodlow Harper, George McDuffitt, and Brooks's own father, Whitfield Brooks. "The Burial of Brooks," Chatham (Canada) Provincial Freeman, February 14, 1857, accessed through Accessible Archives Inc., Primary Resource Material from Congress., $<$ http://www.accessible.com/accesible/text/freedom.htm>.

${ }^{257}$ Senator Josiah Evans as quoted in Congressional Globe, $34^{\text {th }}$ Congress, Third Session, Wednesday, January 29, 1857, 500.

258“Speeches,” 350.
} 
proposed Pacific Railroad that lay at the heart of the Kansas-Nebraska controversy. In speaking in favor of the Pacific Railroad, Brooks showed a bit more creative thinking than in his previous effort, taking a less doctrinaire, more pragmatic approach. ${ }^{259}$ Brooks thought that Congress did not possess the constitutional authority to donate lands that lay within a state, but he had no objection to donating lands within territories for such a purpose. To Brooks this was "a simple question of expediency." 260

Brooks's only other notable action during his first term was to sponsor a petition on behalf of a constituent, identified only as Mrs. Tillman, who had lost her husband and three sons in Mexico and was requesting that she be granted a government pension in the modest amount of eight dollars a month. ${ }^{261}$ In presenting the petition Brooks spoke with such eloquence on Tillman's behalf that Congress voted unanimously to grant her a pension of twenty dollars a month. ${ }^{262}$ While his efforts on Tillman's behalf were commendable, Brooks's overall record in Congress of two mediocre speeches and one successful constituent petition, was hardly enough to make anyone forget about John C. Calhoun. But if less than brilliant, Brooks's record was at least good enough to win him reelection in 1854 .

Brooks's second term was even more inactive than his first term. As before, he offered no major initiatives, and with the exception of another pension petition, he does not appear to

259“Speeches,” 350 \& 352.

260 "Speeches," 352.

${ }^{261}$ Tillman was a relative of Pvt. Tillman of Brooks's Company ' $\mathrm{D}$ ' who was killed at Churubrusco, and of George Tillman with whom Brooks had almost fought a duel years before. "Speeches," 352.

${ }^{262}$ Perhaps to show that he was not an extreme southern partisan, in 1855 Brooks offered similar assistance to a citizen of Massachusetts whose request for a pension had twice been blocked by Southern votes. "Speeches," 352; Mathis, "Image," 302 
have introduced any legislation at all. In fact Brooks appears to have done little to attract attention during this period with the exception of a statement he made in January 1856 during a House debate over the election of a new Speaker, when he spoke in opposition to the candidacy of representative William R. Smith of Alabama on the grounds that Smith was known to harbor strong nativist sentiments. For Brooks the fact that Smith was a fellow southerner was not enough to make Brooks overlook his nativism:

I would vote for Nathaniel P. Banks or Joshua P. Giddings (both vocal slavery foes) a thousand times in preference to that gentleman ... I will never vote for any man who is the enemy of religious freedom. ${ }^{263}$

In summation, then, by the beginning of 1856, Brooks had firmly established himself as one of the leading nonentities in congress. ${ }^{264}$ All that changed in May 1856, when Senator Charles Sumner gave his "Crime Against Kansas" speech. Brooks's response to the speech, and the insulting remarks it contained against his kinsman Senator Butler, in the form of the brutal 'caning' he administered to Sumner, catapulted Brooks out of obscurity and into national political prominence (or infamy, depending upon one's point of view). In the North, press and public lionized Sumner as a hero and condemned Brooks as a villain. ${ }^{265}$ Southern reaction was just as

\footnotetext{
${ }^{263}$ Mathis, “Image,” 302.
}

${ }^{264}$ There are reports that at some point during his time in Congress, Brooks intervened to prevent a duel between two rival newspaper editors. Details of the encounter are sketchy. It is not entirely clear what led to the duel, when it occurred, or indeed if it occurred at all. According to accounts written later, Brooks, stepped between the antagonists and reportedly said: "Remember Mr. Ridgeway (editor of the Richmond Whig), that your antagonist (Pryor-editor of the Richmond Enquirer) is the husband of a youthful and lovely wife, and the father of several young children. Will you make that wife a widow and those children orphans?" Evidently Brooks's words had the desired effect. According to witnesses, the duelists agreed to settle their differences amicably and departed in peace. Mathis, "Image," 301; "Speeches," 363-64.

${ }^{265}$ Only a broad outline of the 'caning incident' and its aftermath is presented here. The episode is dealt with in detail in a subsequent chapter. Donald, Sumner, 298-304, passim; Allan Nevins and Milton Halsey Thomas (eds.): The Diary of George Templeton Strong (New York: The Macmillan Co.; 1952), II, 276; (No Title), New York Tribune, 23 May, 1856, from "Secession Era Editorials Project," Furman University History Department, 
extreme and as partisan as that of the North, especially in South Carolina where huge public rallies were held in support of Brooks and his actions. Throughout the South both press and public rallied to Brooks's support. ${ }^{266}$

In Congress, relations between North and South, already strained by events in Kansas, were severely worsened by Brooks's attack. ${ }^{267}$ Congressmen and Senators on both sides of the Brooks-Sumner affair, threatened violence against Brooks and against each other. One northern congressman, Anson Burlingame of Massachusetts, even accepted Brooks's challenge to a duel. ${ }^{268}$ Both the House and the Senate appointed special committees to investigate the matter. ${ }^{269}$ After much political wrangling a motion to expel Brooks from the House was finally brought to a vote. Although it garnered a majority of 121 to 95, the motion failed to achieve the necessary two-thirds majority. ${ }^{270}$ Still Brooks could read the writing on the wall and resigned the next day,

Furman Online Primary Source Collection (19 $9^{\text {th }}$ Century U.S. < http://history.furman.edu/'benson/ docs (hereafter Furman>, 1; "Attack on Mr. Sumner,"Boston Bee, 23 May, 1856, from Furman, 1; Rochester Democrat, Sept. 3, 1857; Boston Advertiser, May 26-7, 1856.

${ }^{266}$ A few of the South Carolina papers that endorsed Brooks's actions: Columbia South Carolinian; Charleston Mercury; Greenville Patriot and Mountaineer; Spartanburg Spartan and the Yorkville Enquirer, "Public Approval of Mr. Brooks," Columbia South Carolinian, May 27, 1856; "SUMNER CANED BY COL. BROOKS," Greenville Patriot and Mountaineer, May 29, 1856; "BROOKS AND SUMNER," Spartanburg Spartan May 29, 1856; "COL. BROOKS AND SUMNER," Yorkville Enquirer, May 29, 1856, "A New Era," Charleston Mercury, May 29, 1856, from Furman, 1 all from Furman; Schultz: Nationalism and Sectionalism, p. 119; Donald, Sumner, 304-307.

${ }^{267}$ Cong. Globe, 1,306, and Appendix, 631; "The Caning of Sumner," p. 3; Donald, Sumner, 298 \& 307.

${ }^{268}$ Anson Burlingame as quoted in "The Caning of Sumner-Appendix-Voice of the North," Complete Works, Vol. 5, 304; James E. Campbell: "Sumner-Brooks-Burlingame, or, The Last of the Great Challenges," Ohio Archeological and Historical Quarterly, XXXIV (1925), 435-73; The Liberator, XXVI (June 6, 1856), 91; Donald, Sumner, 311.

3.

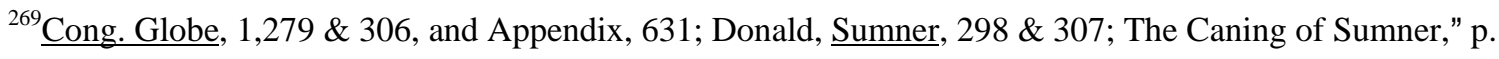

${ }^{270}$ Cong. Globe, Appendix, 656; Donald, $\underline{\text { Sumner, 308; Barney, } 626 .}$ 
July 15, $1856 .{ }^{271}$ He returned to South Carolina and was immediately and overwhelmingly reelected. ${ }^{272}$ Brooks was eventually arrested on charges of assault and made to pay a $\$ 300$ fine. ${ }^{273}$

While Brooks's 'chastisement' of Sumner made him a household name, any hope on his part that it might lead to bigger things, such as a House leadership position or other higher office, quickly ended. Brooks died six months after the Sumner affair of what at the time was variously described as "a severe cold," "the croup," or "an affliction of the throat, of what is technically called laryngitis." ${ }^{274}$ Whatever it was it came upon him with terrifying speed. Brooks first felt its effects on Thursday, January 22, 1857, and took to his bed at Brown's Hotel, Washington, where he resided while in the capital. At first it appeared to be no more than a simple case of the flu and as a result no one thought Brooks was in any danger. In fact Brooks did not even consult a physician for several days. By January 27, Brooks appeared to be on the mend but then, according to those who were present, he was suddenly seized by a severe coughing spasm and after several minutes died "in intense pain."275

Two days later, on January 29, Brooks's close friend, colleague, and accomplice in the Sumner Affair, Representative Lawrence Keitt, formally announced Brooks’s death to the House

${ }^{271}$ Donald, Sumner, 308; Barney, 626.

${ }^{272}$ Donald, Sumner, 308.

${ }^{273}$ Donald, Sumner, 297.

${ }^{274}$ Without more precise information it is impossible to know exactly what killed Brooks. It may indeed have been a severe case of laryngitis or perhaps influenza, or it may have been something else entirely. McKnight, 288-9; Barney, 626.

${ }^{275}$ McKnight, 288-9; Barney, 626; Arthur Lawrence Augustus Gobright, Recollections of Men and Things at Washington, during the third of a century (1869) 419, Making of America, <http://www.hti.umich.edu>; "Speeches," 365. 
of Representatives. ${ }^{276}$ The Clerk of the House, Mr. Cullam, conveyed the news to the Senate chamber. ${ }^{277}$ Senator Evans of South Carolina, rose to say a few words in praise of Brooks and apologized for Senator Butler's absence whose duty it was, as South Carolina's senior Senator and Brooks's kinsman, to deliver such remarks. According to Evans, Butler was so overwhelmed with grief that he was "unable to perform his duty."278

Senator John Quitman, of Mississippi, added a few words of his own to the tribute paid to Brooks and called him a man of "kind heart and the most tender sensibility." Senator Savage of Tennessee in recalling Brooks's attack upon Sumner, left no doubt as to how he believed posterity would regard Brooks's actions.

Brutus stabbed Caesar in the capitol, and whatever may be thought of the justice and wisdom of the deed, the world has ever since approved and applauded the act. So shall the scene in the Senate Chamber carry the name of the deceased to all future generations, long to be remembered after all are forgotten, and when these walls shall have crumbled into ruins. $^{279}$

Brooks's funeral took place on January 29, 1857 at 1:45 p.m. in the capital rotunda. In addition to family members, local dignitaries and federal officials, the funeral was attended by the members of the House and Senate, the Chief Justice and Associate Justices of the Supreme

276“"Speeches," 365.

${ }^{277}$ Journal of the Senate of the United States of America, 1789-1873, (hereafter Senate Journal) THURSDAY, January 29, 1857. A Century of Lawmaking for a new nation: U.S. Congressional Documents and Debates, 1774-1783, American Memory, Library of Congress Website, <http://lcweb2.loc.gov>.

278“"The Burial of Brooks", Chatham (Canada) Provincial Freeman, February 14, 1857. <http:/ /www.accessible.com/accesible/text/freedom.htm.>

${ }^{279}$ Ibid. 
Court, President Buchanan and his cabinet After the funeral the body was taken to the congressional burying ground, where it was temporarily interred. ${ }^{280}$

By February 2, 1857, word of Brooks's death had reached Edgefield where a large public meeting was held, at which the following resolution was passed: "Resolved: That the District of Edgefield and State of South Carolina have lost in the death of Hon. Preston S. Brooks, one of their brightest jewels and most devoted sons."281 Brooks's old comrades from Company ‘D’ held a similar meeting to memorialize Brooks, at which they passed their own resolution which praised Brooks in even more glowing language than had Simkins: ${ }^{282}$

A soldier-a patriot has fallen! The South wails-Carolina weeps, but we, his old comrades in arms, are chief mourners at his tomb. May we not drop the tear of affection over the untimely fate of one so brave, so generous, so chivalric, so loved! In sorrow we pay this feeble tribute to a fellow-soldier, whose friendship we enjoyed, whose gallantry we admired, who virtues we cherished, and whose patriotic services we admired, whose virtues we cherished, and whose patriotic services now embalm his memory in our hearts. Resolved, That in the death of Preston S. Brooks, our late Commander in Mexico, we have lost a staunch friend, and the country a brave soldier, patriot and statesman. ${ }^{283}$

One week later, on February 9, 1857, the body of Preston Brooks left Washington for its long trip back to Edgefield "accompanied by 26 gentlemen from South Carolina." 284 It took five days to reach the town of Hamburg, in Edgefield District, where a large crowd waited to pay their respects. The next day, February 15, 1857, the body was transported via hearse to

\footnotetext{
${ }^{280}$ Brooks's pall-bearers including future Confederate Vice President Alexander H. Stephens. Journal of the House of Representative of the United States, 1856-1857, Thursday, January 29, 1857, 319-320. Accessed through "A Century of Lawmaking for a New Nation: U.S. Congressional Documents and Debates, 1774-1875, The Library of Congress: American Memory. <http://memory.loc.gov/ammem/>.

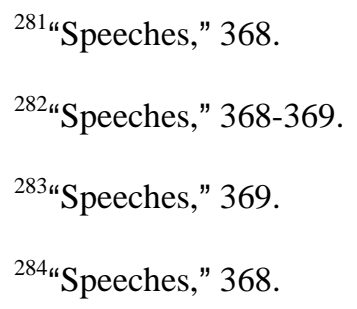


Edgefield village. The coffin was carried through the streets of Edgefield, which were lined with people, to the Court House where "thousands took a melancholy look at it." Finally it was taken to Edgefield cemetery where Preston Brooks was laid to rest in the family plot beside his father, younger brother and first born son, all of whom in a macabre sort of coincidence were named Whitfield. ${ }^{285}$

The problem in dealing with an individual like Preston Brooks, about whom the historical record is so scanty, is that any sort of deeper analysis is extremely difficult. There is simply not enough reliable information about Preston Brooks, and especially not enough primary source material, to state with certainty what Brooks's attitudes were in regard to masculinity. However by examining the circumstances in which Brooks lived and his actions (or reactions) during several key episodes of his life some informed inferences can be made. With that in mind, the image of Brooks that emerges from the limited historical record is that of a man who faced great expectations, and who tried gamely to meet those expectations, but who was never quite able to do so.

As a member of the South Carolina planter class, with its aristocratic pretensions and assumptions of superiority, young Preston Brooks would have grown up being constantly reminded of his status as a member of the ruling elite and of the expectations that came with that status. $^{286}$ And looking at the circumstances of his life, there is little doubt that Brooks was profoundly influenced by the standards and defining characteristics of southern masculinity such

\footnotetext{
${ }^{285}$ Brooks is buried in the same cemetery as recently deceased United States Senator J. Strom Thurmond; "Speeches," 626.

${ }^{286}$ Fraser, 12; Wertenbaker, 1 \& 7; Rozbicki, 12, 16, 37 \& 59.
} 
as morality, religious piety, adoration of womanhood, and especially martial spirit. ${ }^{287}$ His ability to meet those standards was another question.

Further reinforcing his status as a member of the planter elite was the fact that Brooks could claim a heritage as esteemed as any in the South. It was obvious to everyone who knew them, and most of all to themselves, that the Brooks and Butler families more than lived up to the aristocratic ideal. This was especially the case with the Butlers who, with their claimed ties to British nobility seemed to be living proof of the validity of the "Cavalier Myth." Indeed, if any family could be said to represent the aristocratic nature of "Southern Chivalry" the Butlers were that family. They were proud, upstanding, uncompromising and most of all they were fighters. They fought, even to the death, for South Carolina, for the South, for the nation and for honor (not necessarily in that order). The image of his cousin James Butler Bonham fearlessly facing down hordes of Mexican soldiers at the Alamo, alongside such legendary examples of American manhood as Davy Crockett and Jim Bowie, must have left an indelible impression upon Brooks's psyche. ${ }^{288}$ The fact that Bonham had made the ultimate sacrifice by giving his life for liberty (as nineteenth century Americans saw it) would have left little doubt in young Preston's mind as to exactly what was expected of him as a southern man.

And it seems clear from all that is known about him, that Preston Brooks was not only aware of those expectations but actively endeavored to live up to them. Beginning with his days at South Carolina College, when he nearly came to blows with a fellow student over a disputed

\footnotetext{
${ }^{287}$ Castiglione, 60-62, 251; Malory, Le Morte D’Arthur, xiii \& 57; Wright, 8-14; Lull, 57 \& 58; Kennedy, 15 \& 45; Wertenbaker, 54, 67-8, 80, 83, 85-6, 96, 99-100, 104-5; McPherson, 313, Ownby, 34; Potter,377 458; Rozbicki, 13, 14.

${ }^{288}$ Brooks Historian.
} 
election and attempted to break his brother out of jail, Brooks strived very hard to project an image of himself as an aggressive, commanding southern male. As William Barney has observed, there is little doubt that Brooks would have been pleased with the epitaph carved on his headstone which proclaimed him "ever able, manly, just and heroic."289

Even Brooks's reputation as an indifferent student is in keeping with this framework of antebellum masculinity. While knowledge and learning were traditionally regarded as characteristics associated with masculine virtue, many southerners felt that a gentleman should be educated, but should not be too educated. Furthermore the fact that Brooks often did not attend class and instead preferred to spend time at the local tavern was very much in keeping with the antebellum fascination of men for rowdy pastimes.

This pattern of aggressive behavior continued into adulthood. Brooks fought at least two duels. The first was with a neighbor named George Tillman, which interestingly enough was apparently caused by Tillman's "uncontrollable" resentment toward what he considered the "snobbishness of the Brooks family and other members of the 'upper circle' in Edgefield." Luckily the dispute with Tillman was resolved without injury to either party, when Tillman backed down. ${ }^{290}$ The same cannot be said of Brooks's June, 1841, duel with his former college roommate, Lewis T. Wigfall. ${ }^{291}$ The fact that Brooks's encounter with Tillman had been resolved without injury to either party probably emboldened him to take a harder line in dealing

\footnotetext{
${ }^{289}$ Barney, 626.

${ }^{290}$ Mathis, “Image," 299.

${ }^{291}$ McKnight, 288-289; Barney, 625; Mathis, "Image," 300.
} 
with Wigfall. $^{292}$ Having called Tillman's bluff, only to have him back down, Brooks may have been persuaded to try the same tactic with Wigfall in the expectation that Wigfall would also back down. If this was Brooks's thinking it showed a serious lack of judgement. In fact Brooks was playing a dangerous game. Wigfall, who had already dueled with two of Brooks's relatives and killed one of them, was not bluffing. Despite being seriously wounded in the encounter, Brooks was lucky to have not been killed. ${ }^{293}$

But while Brooks attempted to project the image of a bold man of honor, with the exception of the Wigfall affair the pattern that emerges is not one of boldness or of one who met challenges head-on, but of a man who repeatedly backed down. Witness the controversy regarding Brooks' service in Mexico. Like many young men his age, Brooks eagerly joined the rush to the colors and not only volunteered himself, but also demonstrated his status as a leader of the community by actively recruiting a company from the town of Edgefield. No doubt at least part of Brooks's motivation was the fear of being thought a coward should he not volunteer. Apparently Brooks had good reason for thinking this might be the case. Judging from their war record, Company 'D' and the rest of the Palmetto Guards were as motivated and aggressive a set of warriors as any that served in Mexico and saw action at Vera Cruz, Cerro Gordo, Contrera, Churubrusco, and Chapultepec. ${ }^{294}$ The regiment faced its toughest challenge at the Battle of Churubrusco on August 20, 1847, where it was ordered to make an ill-advised frontal assault against superior numbers. Although the attack succeeded, the Palmetto Guards suffered the

\footnotetext{
${ }^{292}$ Mathis, "Image,” 299.

${ }^{293}$ McKnight, 288-9; Barney, 625; Mathis, “Image,” 300.

${ }^{294}$ Henry, 246, 264, \& 469; Bauer, 263, 265, 298-299 \& 511.
} 
highest casualty rate among American forces, almost ten percent of the total American losses of 137 killed and 879 wounded. ${ }^{295}$

Among the losses suffered by the regiment in this bloodbath were Colonel Butler who, after being wounded, continued to lead his regiment until he was shot in the head. The regiment also lost its second-in-command, Lt. Colonel John P. Richardson, who fell mortally wounded (he died a few days later) a few minutes after Butler. With the loss of the Commanding and Executive Officers, command of the regiment fell to Major Adley H. Gladden who was also wounded. In addition to Butler, Richardson and Gladden, the regimental staff also lost Captain J.D. Blanding (ACS) and Adjutant James Canty. ${ }^{296}$ Like the rest of the regiment, Company 'D' suffered greatly in the attack. In addition to those killed--Second Lieutenant Davis Adams and Private Thomas Tillman--the company also reported eleven wounded. Among the wounded was Brooks's younger brother Whitfield, who died in Mexico City on October 7, 1847..$^{297}$

While his younger brother had lived up to the ideals of the Southern code of honor and died a hero's death, Preston Brooks's own war record was far less heroic. In fact it is not entirely clear that Brooks can even be said to possess a 'war record.' He may or may not have been in combat early in the war, depending upon whose account one chooses to believe. What is not in

\footnotetext{
${ }^{295}$ The New York volunteers also suffered heavy casualties. As a whole Shields's brigade lost almost onethird of their numbers. Bauer, 298-299; Henry, 342.

${ }^{296}$ Henry, 340.

${ }^{297}$ The wounded of Company 'D' at Churubrusco included: $2^{\text {nd }}$ Lt. Joseph Abney, Cpl. Whitfield Butler Brooks and Privates: James Goff, J. Whittaker; J. Addison; F. Posey ; R. J. Key; W. F. Uthank; J. Lark; E. Simkins and R. Sloman. O'Neall, "Whitfield Brooks," 474; 30 ${ }^{\text {th }}$ Congress, $1^{\text {st }}$ Session, Executive Document No. 8: Message from the President. Daily American Star, Mexico City, Mexico, Vol. 1, No. 34, November 9, 1847, pp. 1-2; as cited by "Roll of Honor-U.S. Casualties in the Battles of Churubusco and Contrera, PART THREE"

<http://www.dmwv.org/honroing/chucon3.htm.> John A. Quitman, Eulogy of Preston S. Brooks, Congressional Globe, $34^{\text {th }}$ Congress, Third Session, Wednesday, January 29, 1857, 500.
} 
dispute is the fact that in the middle of the campaign against Mexico City Brooks contracted typhoid fever and was 'forced' to return to South Carolina to recuperate in June 1847. By the time he returned to Mexico in September the fighting was pretty much over. ${ }^{298}$

What happened before Brooks contracted typhoid fever was a matter of great contention at the time. Lawrence Keitt, in his eulogy of Brooks, rather vaguely asserted that he "shared the earlier and later events of the campaign between Vera Cruz and the City of Mexico." ${ }^{299}$ Brooks's Division Commander, John A. Quitman, in his eulogy of Brooks was more definitive than Keitt, flatly declaring that Brooks "saw action at Vera Cruz." In fact Quitman claimed that he saw Brooks on the front lines "sharing with his men the provations(sic), the danger and the triumphs of that famous siege." 300

Apparently, however, not everyone was convinced, and there is some indication that Brooks's comrades in the Palmetto Guards thought his sudden affliction and equally sudden recovery a bit too 'convenient.' While it can never be known with certainty what was said and by whom it was said, the attitude of Brooks's comrades toward his war record was perhaps best indicated by an incident that took place after the war when the community of Edgefield decided to honor those who had fought in Mexico by presenting each man with a sword. At the

${ }^{298}$ Barney, 625; Keitt, “Eulogy,” 500.

${ }^{299}$ Keitt, "Eulogy," 500.

${ }^{300}$ At first blush Quitman may seem like an unimpeachable witness. However it should be pointed out that in the same eulogy for Brooks, Quitman incorrectly stated that Pierce Butler and Whitfield Brooks were both killed at Chapultepec, not at Churubrusco as actually occurred. Quitman, "Eulogy," 500. 
ceremony, which took place on July 4, 1849, one man was conspicuously absent. Preston Brooks had been completely excluded from the proceedings. ${ }^{301}$

To Brooks such a snubbing was an insult to both his honor and to his reputation as a gentleman, and as such could not go unanswered. Brooks was so incensed at being, in his words, 'unjustly neglected' that he attacked the war records of his former comrades who had been honored. Among those whose courage Brooks questioned was his own cousin Milledge Luke Bonham. Cousin or no cousin, Bonham who had served as a Lt. Colonel with the $12^{\text {th }}$ Infantry regiment and who had been wounded at Churubrusco was not about to allow Brooks to get away with this sort of disinformation. Tensions between the two quickly reached the boiling point and almost led to a duel. Obviously both Brooks and Bonham considered honor to be a deadly serious matter, well worth fighting for, even with a relative. ${ }^{302}$

The fact that Milledge Bonham was not only Brooks's cousin but also the brother of Alamo defender James Butler Bonham may have further contributed to the dispute. It is quite conceivable that Brooks's resentment toward Bonham may have been due to a sense of guilt over having fled the war zone and left it up to his cousin alone to uphold the family honor and avenge the death of not only James Bonham death but that of his brother Whitfield as well. ${ }^{303}$ Perhaps deep inside Brooks realized that he had failed to meet the expectations of southern manhood. Certainly, the fact that both his cousin and his brother had fought bravely in Mexico must have wounded his pride.

\footnotetext{
${ }^{301}$ Barney, 625.

${ }^{302}$ Barney, 625; Henry, 340.

${ }^{303}$ Barney, 625.
} 
This need to prove himself may have also provided at least part of the motivation for Brooks's attack upon Charles Sumner. This topic will be dealt with at length in a subsequent chapter, but for now suffice it to say that Brooks's exclusion from the sword ceremony would seem to indicate that questions were raised around Edgefield concerning Brooks's service in Mexico. In addition, the fact that Brooks had not carried out his threat to duel Milledge Bonham and had also drawn criticism from constituents for his somewhat lackluster performance in congress, may have led him to regard Sumner's verbal assault upon Andrew Butler as an opportunity to redeem himself, both politically and as a man. ${ }^{304}$ Having failed to defend southern and family honor on the battlefields of Mexico, he would do so in the halls of congress.

${ }^{304}$ During the debates over the Kansas-Nebraska bill, Brooks drew criticism for being "a little too national." Harold S. Schultz, Nationalism and Sectionalism in South Carolina: 1852-1860; 115-16; Congressional Globe, Appendix, 876; Donald, Sumner, 289-90. 


\section{CHAPTER 4:}

\section{CHARLES SUMNER}

Born January 6, 1811, Charles Pinckney Sumner was the eldest of nine children born to Relief Jacobs Sumner and Charles Pinckney Sumner, Sr. ${ }^{305}$ Sumner was fairly well educated by nineteenth century standards and attended the Boston Latin School and Harvard University where the subjects he studied Latin, Mathematics, English, Grammar, Philosophy, Natural Sciences and History, among other subjects. At Harvard Sumner was described as a "moderately successful student," one who excelled in the humanities but struggled in mathematics. ${ }^{306}$ Sumner graduated from Harvard in 1830. In 1831, after taking off a year for "independent study" Sumner enrolled at Harvard Law school where he graduated in $1834 .^{307}$

\footnotetext{
${ }^{305}$ Sumner's siblings included twin sister Matilda, brothers Albert, George, Henry, Horace, and younger sisters Jane, Mary, Julia. David Herbert Donald, Charles Sumner and the coming of the Civil War, (New York: Knopf, 1960) (hereafter, Donald, Sumner) 5-8, 11; Elias Cason, The Life and Times of Charles Sumner, (Boston: B.B. Russell, 1874), 11-14, 15, 16; "Introduction to Volume 1" Memoirs and Letters of Charles Sumner vol. I, 18111838, edited by Edward L. Pierce (Boston: Roberts Brother, 1877) (hereafter Sumner Memoirs) 1.

${ }^{306}$ At the time Sumner attended Harvard, the yearly curriculum consisted of the following: Freshman Year: Collectanea Graeca Majora, Livy, Grotius de Veritate Religianis Christianae, Plane Geometry, Adams's Roman Antiquities, Horace, Algebra, Greek, Excerpta Latina, English Grammar; Sophomore Year: Collectanea Graeca Majora (cont), Greek (cont), Excerpta Latina (cont), Geometry of Planes and Solids, History, Cicero de Oratore, or an equivalent in Latin, Analytick (sic) Geometry, Blair's Lectures on Rhetorick (sic), Topography; Junior Year: Topography (cont), Logic, Moral Philosophy, Hebrew or a substitute, Chemistry, Tacitus or an equivalent in Latin, Homer's Iliad or other Greek, Differential Calculus or a substitute, Mechanicks (sic) Electricity and Magnetism; Senior Year: Intellectual Philosophy, Optics, Astronomy, Paley's Evidences, Butler's Analogy, Political Economy, Chemistry, Mineralogy, and Geology, or a substitute, Philosophy of Natural History. Samuel Eliot Morrison, Three Centuries of Harvard, 1636-1936 (Cambridge, Mass.: The Belknap Press of Harvard University Press, 1965) 205; "Introduction to Chapter Four: College Life" Sumner Memoirs vol. 1, 47; Donald, Sumner, 8, 11-13, 14, 16, 17 \& 18; Cason, 24-26.

${ }^{307}$ Pauline Holmes: A Tercentenary History of the Boston Public Latin School, 1635-1935 ("Harvard Studies in Education," Vol. XXV; Cambridge: Harvard University Press; 1935), 192, 194, 269-71, as cited in Donald, Sumner, 8, 9 -11 \& 16; James Brewer Stewart, Wendell Phillips, Liberty's Hero (Baton Rouge: Louisiana State University Press, 1986) 9; Record of The Harvard College Faculty, III, 258, 265; IV, 6, 60; as cited in Donald, Sumner, 5, 7, 11; "Introduction to Chapter Four: College Life" Sumner Memoirs 47; Donald, Sumner, 8, 11-13, 16, 17, 18-20 \& 21-22, 25-26, 81; Introduction, Sumner Works, Vol. 1, viii; Cason, 18-21, 23-26, 37, 38, 39.
} 
After law school Sumner read law in the office of Boston attorney Benjamin Rand. He was admitted to the bar in September, 1834, and began a partnership with close friend George S. Hilliard. $^{308}$ In December, 1837, Sumner departed for a two-and-a-half year tour of Europe from which he returned to Boston in May $1840 .{ }^{309}$ In 1844, Sumner first became involved in the antebellum reform movements and particularly in education reform. In 1845 Sumner ran unsuccessfully for a seat on the Boston School committee. ${ }^{310}$ In July of that year Sumner delivered Boston's annual Fourth of July Address, "The True Grandeur of Nations," in which he attacked the "Slave Power" for its alleged complicity in the annexation of Texas. ${ }^{311}$ The speech attracted a great deal of attention and helped establish Sumner as a potent voice within the abolitionist movement. $^{312}$

\footnotetext{
${ }^{308}$ Donald, Sumner, 28-35; Cason, 42-44, 45-46.; Introduction Sumner Works, Vol. 1, viii; "Introduction to Chapter VIII," 123.

${ }^{309}$ Donald, Sumner, 43, 44, 45-6, 51, 65-8; Cason, 48-50, 54-56; Introduction, Sumner Works, Vol. 1, viiviii, ix; C.S. to G.H., November 4, 1838, 11-12, December 4-5, 1838, 12-13, December 11 \& 14, 1838, 29-31, January 6 \& 12, 1839, 36-49, February 16, 1839, 59-70, March 13, 1839, 79-81, April 15, 1839, 88-89, April 20, 1839, 89-90, May 19, 1839, 99-101, July 13, 1839, 103-104, July 26, 1839, 104-106, October 18, 1839, 122-125, December 25, 1839, 127-130, April 4, 1840, 146-17, C.S. to Justice Joseph Story (hereafter .J.S.), November 4, 1838, 12-13, December 12-14, 1838, 24-28, January 23, 1839, 52-58, March 9, 1839, 72-77, C.S. to Lord Morpeth, March 5, 1839, 71-72, C.S. to Henry W. Longfellow, July 26, 1839, 106-107, C.S. to Professor Simon Greenleaf, July 27, 1839, 108-109, all in Sumner Memoirs; Cason, 57-59.

${ }^{310}$ C.S. to George Sumner, July 1, 1844 and C.S. to George Sumner, July 31, 1844, C.S. to Samuel G. Howe, August 16, 1844, all in Sumner Works, 309 \& 311-312; Introduction, Sumner Works, Vol. 1, x; Schwartz, Howe, 147-149; Donald, Sumner, 87, 96-97, 99-104, 106, 120-28, 165-6; Cason, 63-64, 89-90, 112-13; Schwartz, Howe, 126, 128; Jonathan Messerli, Horace Mann, A Biography (New York: Alfred A. Knopf, 1972$) 238$.

${ }^{311}$ Charles Sumner, "The True Grandeur of Nations” Sumner Works, Vol. 1, 9; Claude Moore Fuess, Daniel Webster, vol. 1 (Hamden, Connecticut: Archon Books, 1963), 295; Messerli, Mann, 448.

${ }^{312}$ Sumner, "True Grandeur of Nations," 9; Cason, 65 \& 68; C.S. to Rev. Robert C. Waterston, July 1845, 374-375, C.S. to Nathan Appleton, Pittsfield, August 18, 1845, 375-376, C.S. to Henry K. Oliver, Adjutant General, Boston, August 20, 1845, 376, C.S. to Richard H. Dana, August 1845, 377, C.S. to Horace Mann, August 1845, 377, C.S. to Richard Rathbone, Liverpool, February 28, 1846, 378-379, all in Sumner Memoirs.
} 
During the next few years Sumner continued in his legal career but a steady decrease in clients forced him to seek outside employment. ${ }^{313}$ Part of the reasons for the decline of his legal practice was the fact that Sumner's increasing preoccupation with antislavery activity. Sumner would become one of the leading antislavery (or "Conscience") Whigs in Massachusetts. In fact Sumner's deep commitment to the antislavery cause led him to leave the Whigs when they selected Mexican War hero Zachary Taylor as their 1848 presidential candidate. Sumner and his fellow Conscience Whigs eventually helped form a new political organization called the Free Soil Party of which Sumner was selected state central committee chairman. Sumner was also nominated for congress but declined to run. ${ }^{314}$

Sumner was nominated again for Congress in 1850, this time to fill a vacancy created by the selection of Representative Robert C. Winthrop to replace Daniel Webster in the Senate when the latter was chosen as Millard Fillmore's Secretary of State. Unfortunately Webster, angered over Sumner's characterization of him as a "traitor to a holy cause" for the "Seventh of March" speech in which Webster had defended the Compromise of 1850, used his considerable political clout to deny the election to Sumner. The following year, 1851, Sumner decided to

${ }^{313}$ Cason, 45-6.

${ }^{314}$ As a pacifist, Sumner would have found the selection of any military man disagreeable. However the fact that Taylor had not only gained fame in a war that Sumner saw as having been brought about by the slave power, but was a slaveholder himself, made him intolerable to Sumner. Donald, Sumner, 87, 136, 137, 147-52, 154, 155-162, passim; 165-168, 177 Cason, 81, 82, 85, 86-87, 93-4, 96, 97, 112-113, 115-117; Sumner, "Letter to Robert C. Winthrop, Representative in Congress," and "Refusal to be a Candidate for Congress, Notice in the Boston Papers," October 31, 1846, both in Sumner Works, Vol. 2,, 317 \& 331-332; Sumner, "The Party of Freedom, Speech on Taking the Chair as Presiding Office of the Public Meeting to Ratify the Nominations of the Buffalo Convention, At Faneuil Hall," August 22, 1848, Sumner Works, Vol. 2. 292-298; Introduction, Sumner Works, Vol. 1, xi. Schwartz, 163, 168, 169; John L. Thomas, The Liberator: William Lloyd Garrison, A Biography (Boston: Little, Brown \& Company, 1963) 341-342; Baxter, 395; Claude M. Fuess, The Life of Caleb Cushing vol. 2 (Hamden Conn.: Archon Books, 1965) 38; Messerli, Mann, 456 \& 470. 
challenge Winthrop for the his Senate seat. Despite Webster's continued interference, Sumner defeated Winthrop and entered the Senate in December $18511^{315}$

As one of only a handful of anti-slavery senators, it was only natural that Sumner would become enmeshed in the controversy surrounding Stephen Douglas's Kansas-Nebraska Bill. ${ }^{316}$ Sumner, along with Senators Salmon P. Chase, J.R. Giddings, Edward Wade, Alexander De Witt and Gerrit Smith, wrote a scathing editorial for the January 19, 1854, edition of The National Era entitled the "Appeal of the Independent Democrats" which condemned the Kansas-Nebraska Act as "a gross violation of a sacred pledge" and "an atrocious plot to . . convert (Kansas) into a dreary region of despotism, inhabited by masters and slaves."317 Even after the passage of the Kansas Act, Sumner refused to give up the fight. In the months following the bills' passage, Sumner gave speech after speech condemning both the Kansas-Nebraska and Fugitive Slave Acts. ${ }^{318}$ After the collapse of the Free Soil and Whig parties, following the passage of the KansasNebraska Act, Sumner joined the Republican party, which was specifically dedicated to

${ }^{315}$ Donald, Sumner, 184-189, passim, 195-198, 200-02, 205-206, 208-209; Maurice G. Baxter, One and Inseparable: Daniel Webster and the Union (Cambridge, Mass.: Harvard University Press, 1984) 373, 390, 413-416; Cason, 81, 129-130, 136-137, 138-9; Fuess, Cushing, vol. 2 101-102; Fuess, Webster vol. 2, 198-199, 240-241, 271; Richard N. Current, Daniel Webster and the Rise of National Conservatism, (Boston: Little Brown and Company, 1955) 177; Richard H. Abbott, Cobbler in Congress: The Life of Henry Wilson, 1812-1875, (Lexington: The University Press of Kentucky, 1972) 42-43; Niven, 143; Messerli, Mann, 523-528, passim; Fawn M. Brodie, Thaddeus Stevens, Scourge of the South (New York: W.W. Norton \& Company, Inc., 1959) 114; Davis, Hour, 193; Eaton, 70; "Biographical Directory of the United States Congress," FirstGov.gov. http://www.firstgov.gov/ Agencies/Federal/Legislative.html.

${ }^{316}$ McPherson, Battle Cry, 108, 121, 122, 123 \& 124; Potter, Impending Crisis, 159, as cited in McPherson, Battle Cry, 123.

${ }^{317}$ McPherson, Battle Cry, 123 \& 124; Davis, Hour, 231 \& 245, 247-8, Cason, 174, 211; S.P. Chase, Charles Sumner, J.R. Giddings, Edward Wade, Gerrit Smith, Alexander De Witt, "Appeal of the Independent Democrats," January 19, 1854. AFRO-American Almanac, Historical Documents. http://www.toptags.com/aama/docs/demapped.htm.

${ }^{318}$ Cason, 204; Sumner, "The Demands of Freedom; Repeal of the Fugitive Slave Act," Sumner Works, Vol. 4, 338-339. 
opposing Kansas-Nebraska and quickly became one of the Republicans' earliest leaders in Massachusetts. $^{319}$

In 1856, there came the outbreak of virtual civil war in Kansas between rival pro-slavery and free-soil factions. As both parties sought, in a presidential election year, to exploit "Bleeding Kansas" for all the propaganda value that it was worth, the level of political rhetoric became ever more heated and bitter on both sides. To present the Democratic (and Southern) version of events, Stephen Douglas took the floor on March 12, 1856, and delivered a speech that was both predictably partisan and sympathetic to the pro-slavery faction. ${ }^{320}$ The Republican side quickly responded beginning on April 9, 1856, with New York Senator William A. Seward. ${ }^{321}$ On May 19, 1856, Sumner took the floor to deliver his own rebuttal to Douglas in "The Crime Against Kansas."322

${ }^{319}$ Cason, 207-9; McPherson, Battle Cry, 110, 125-6, 130-8, 140, 141, 143-44; Michael F. Holt, The Political Crisis of the 1850s, (New York: W. W. Norton \& Company, 1978) 148-152, 164-166, 172, 174, 180-181, 186; Cason, 198, 202; Sumner, "The Duties of Massachusetts at the Present Crisis," Sumner Works, Vol. 4, 278-279; Hans L. Trefousse, The Radical Republicans (New York: Alfred A. Knopf, 1969) 92.

${ }^{320}$ McPherson, Battle Cry, 145-48; Nevins, Ordeal, II, 473, 475; Nicole Etcheson, Bleeding Kansas: Contested Liberty in the Civil War Era (Lawrence: The University Press of Kansas, 2004) 48, 68, 72, 74-75, 78-79, 89, 92, 97, 102, 116; William A. Seward, "Memoir, Biographical and Historical," vol. iv The Works of William H. Seward (hereafter Seward Works) George Baker, ed., (Boston and New York: Houghton, Mifflin \& Co., 1884) 39; Sumner, Sumner, 278-280; Cason, 212.

${ }^{321}$ William A. Seward, “The Immediate Admission of Kansas,” Seward Works, 479-481.

${ }^{322}$ Sumner to Longfellow, Apr. 7, 1856, Longfellow MSS.; Receipts for Books, Library of Congress Records, 1855-7, 49, 181; Washington Correspondence of New York Evening Post, May 21, 1856, in W. S. Thayer

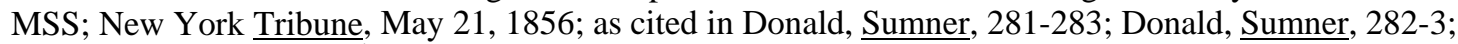

Congressional Globe, $34^{\text {th }}$ Congress, $1^{\text {st }}$ session. Appendix, 545, in Nevins, 439; Gamaliel Bradford, Union Portraits, 233-261; James K. Hosmer, The Lost Leaf, 18-25; Julia Ward Howe, Reminiscences 1819-1899, pp. 171-182; See also Emerson's sketch in The Early Years of the Saturday Club, 1855-1870, pp. 296-308; all in Nevins, 437; Recent Speeches and Addresses in Nevins, 438; Cason, 205 \& 214; L. A. Gobright, Recollcetions of Men and Things at Washington, 150, in Nevins, 437; Congressional Globe, $34^{\text {th }}$ Congress, $1^{\text {st }}$ session, Appendix, 545, in Nevins, 439. 
As one who aspired to the status of a New England intellectual, Charles Sumner embraced many of the values of that class and that region including those values associated with masculinity. Sumner possessed a deep sense of Christian morality and he adhered to such middle-class virtues as thrift, piety, sobriety, civic-mindedness and learnedness. ${ }^{323}$ In his professional life, Sumner was habitual to a fault and possessed a strong sense of professionalism and dedication to duty, following virtually the same routine every day of his life. While serving in the Senate Sumner made it a point to walk the mile distance from his boarding house to the Capitol building and always "made it a point to be in his place each morning when the Senate was called to order." He remained at his desk all day where he closely followed the proceedings allowing "nothing to distract his attention." 324

Sumner more than measured up to the antebellum ideal of "gentlemanly" behavior with its emphasis on gentility, good manners, integrity, refinement of dress and a sense of proper social decorum. ${ }^{325}$ Indeed in some ways, despite the fact the he often took a broad-minded approach to social issues, when it came to matters of morality Sumner was remarkably straight-

${ }^{323}$ Norma Basch, "Marriage, Morals, and Politics in the Election of 1828," The Journal of American History, Vol. 80, No. 3, (December, 1993), 892-894., 895-896; 901; Gorn, “'Good-Bye Boys,” 401, 403, 404, 405, 406, 407; Introduction, Meanings for Manhood, 6-7; T.H. Breen, Timothy Hall, "Structuring Provincial Imagination in the Rhetoric and Experience of Social Change in Eighteenth Century New England," The American Historical Review, Vol. 103, No. 5 (December, 1998) 1420; Anna Clark, "The Chevalier d'Eon and Wilkes: Masculinity and Politics in the Eighteenth Century," Eighteenth Century Studies, Vol. 32, No. 1, (1998), 20; Bradford, Union Portraits, 233-261; James K. Hosmer, The Lost Leaf, 18-25; Julia Ward Howe, Reminiscences 1819-1899, pp. 171182; Brodie, 119-120.

${ }^{324}$ Donald, Sumner, 207.

${ }^{325}$ Basch, "Marriage, Morals, and Politics," 892-894., 895-896; 901; Gorn, “'Good-Bye Boys," 401, 403, 404, 405, 406, 407; Introduction, Meanings for Manhood, 6-7; Breen, Hall, "Structuring Provincial Imagination," 1420; Clark, "The Chevalier d'Eon,” 20; Etcheson, "Manliness", 70-71. 
laced even for that religious age. Sumner was offended by much of what he saw during his

European tour, including the gambling halls of Paris and the "immorality and total depravity" of

European women. Sumner found it shocking that English gentlemen gambled and that the upper

class frequently cursed and discussed topics that would have been considered taboo in New

England. $^{326}$

But, when it came to domestic affairs, Sumner's own family relations, while they were certainly patriarchal, otherwise fell far short of the middle-class ideal of domestic harmony. As the eldest male among nine children, Sumner was expected, far more than his siblings, to live up to his father's exacting standards. This was no easy task. Sumner's father, Charles Sumner Sr., has been described by at least one writer as a "singularly unlovable man." Being of illegitimate birth, Charles Sr. grew up having to bear the social stigma that illegitimacy carried with it in that place and time. This seems to have bred within him a rigid and unforgiving personality that made him unwilling to overlook the faults of others, especially those of his eldest son. At times Sumner must have felt, perhaps justifiably so, that nothing he did would ever satisfy his father's rigid standards. ${ }^{327}$

${ }^{326}$ Donald, Sumner, 43, 44, 45-6, 49, 51, 58-59, 65-8; Cason, 48-50, 54-56; Introduction, Sumner Works, Vol. 1, ix; C.S. to G.H., November 4, 1838, 11-12, December 4-5, 1838, 12-13, December 11 \& 14, 1838, 29-31, January 6 \& 12, 1839, 36-49, February 16, 1839, 59-70, March 13, 1839, 79-81, April 15, 1839, 88-89, April 20, 1839, 89-90, May 19, 1839, 99-101, July 13, 1839, 103-104, July 26, 1839, 104-106, October 18, 1839, 122-125, December 25, 1839, 127-130, April 4, 1840, 146-17, C.S. to Justice Joseph Story (hereafter J.J.S.), November 4, 1838, 12-13, December 12-14, 1838, 24-28, January 23, 1839, 52-58, March 9, 1839, 72-77, C.S. to Lord Morpeth, March 5, 1839, 71-72, C.S. to Henry W. Longfellow, July 26, 1839, 106-107, C.S. to Professor Simon Greenleaf, July 27, 1839, 108-109, all in Sumner Memoirs; John Niven, Salmon P. Chase: A Biography (New York: Oxford University Press, 1995) 143.

${ }^{327}$ Donald, Sumner, 5-8 \& 11; Cason, 16-18; Introduction: Sumner Memoirs, vol. I, 30. 
Certainly the elder Sumner exerted an inordinate degree of authority over his son and tried to control every aspect of his life. While Sumner was a student at Harvard, his father maintained such a tight leash that Charles was required to return home every Sunday to report on his activities. $^{328}$ Like most young men of college age, Charles gradually began to assert his independence and to resist parental supervision. Sumner's father, for his part, grew resentful at what he considered Charles's rebellious nature. Just how far Sumner was prepared to go in pursuit of his independence, became clear in December 1837 when he departed for Europe. Charles's determination to go ahead with the trip, despite his father's strong opposition, was in part an indication of Sumner's natural curiosity. But it must have also been motivated by a desire to escape his father's oppressive oversight as evidenced by the fact that when Sumner's father died in the middle of the trip, Charles made no effort to return home. Sumner's true feelings on the matter were perhaps best expressed when he wrote to a friend: "I cannot affect to feel entirely the grief that others have on such a bereavement." ${ }^{329}$

Sumner's dysfunctional relationship with his father bred with him a deeply felt need for the company and approval of men. The most important, and longest lasting, relationships of Sumner's life were his relationships with men. Sumner liked and enjoyed the company of women, but he craved the respect and the approval of men, especially older men from whom he

${ }^{328}$ Donald, Sumner, 9, 11, 12-13, 14 \& 18; Cason, 33-35.

${ }^{329}$ Relief Sumner could be just as stern and demanding as her husband, but evidently she also had a softer side. When Charles's debts grew so large that he could not pay them, his mother came to his rescue and paid them in full. Donald, Sumner, 68-73, 75-77; Cason, 11-14, 15, 16-18, 57-58; Charles Sumner to George S. Hillard, July 13, 1839, Sumner Memoirs 103; Record of The Harvard College Faculty, III, 258, 265; IV, 6, 60; as cited in Donald, Sumner, 5-7, 11. 


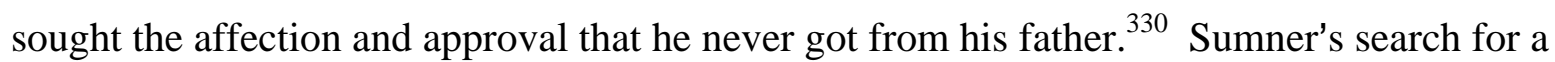
surrogate father began during his days at Harvard Law School when he studied under Harvard Professor, and U.S. Supreme Court Justice, Joseph Story. In Story Sumner seemed to find the perfect substitute parent. Indeed David Donald, in his biography of Sumner described the relationship in just those terms: "For Sumner, who had for so many years sought but never secured his father's approbation, winning Story’s approval became a chief goal in life.”331 Story probably had more influence over the development of Sumner's character and of his legal and political ideas than any other single individual, including Sumner's father. It was Story who convinced Sumner to enter the legal profession in the first place and it was from Story that Sumner derived much of his legal philosophy including his views on equity and human rights. ${ }^{332}$ Story became teacher, mentor, role model, and even surrogate father to Sumner. Sumner, in turn became almost a second son to Story, who once expressed the hope that Sumner would succeed him at Harvard Law. ${ }^{333}$

Like any father, surrogate or otherwise, Story took a vested interest in Sumner's career prospects. During Sumner's studies at Harvard Law School, when it appeared that financial

${ }^{330}$ Donald, Sumner, 16, 81.

${ }^{331}$ Donald, Sumner, 24.

${ }^{332}$ Donald, Sumner, 21, 23, 24, 27; Gerald T. Dunne, Justice Joseph Story and the Rise of the Supreme Court (New York: Simon and Schuster, 1970) 319; Charles Sumner, "Tribute of Friendship: The Late Joseph Story," Boston Daily Advertiser, September 16, 1843, Sumner Works, vol. 1, 133; Cason, 40, 69-72; 74-75; Introduction, Sumner Works, Vol. 1,viii, xii; Schwartz, Howe, 155; Ernest McKay, Henry Wilson, Practical Radical: Portrait of a Politician (Port Washington New York: Kennikat Press, 1971) 34.

${ }^{333}$ Dunne, Justice Story, 319; Life and Letters of Joseph Story edited by William W. Story (vol. 2) Freeport, New York: Books for Libraries Press, 1851 (reprinted 1971)) 39; Judge Story's own son, William, described his father's relationship with Sumner, and with Sumner's law partner, George S. Hilliard as follows: "he rather looked upon (them) as his children than his pupils." William W. Story, vol.2 Life and Letters, 39; also Story to Sumner, August 11, 1838, Life and Letters, 297. 
hardship might force him to withdraw, Story went to considerable lengths to ensure that Sumner would have the means to complete his third and final year. Story arranged several part-time jobs for Sumner, and had him appointed as law school librarian, hired Sumner to proof-read his

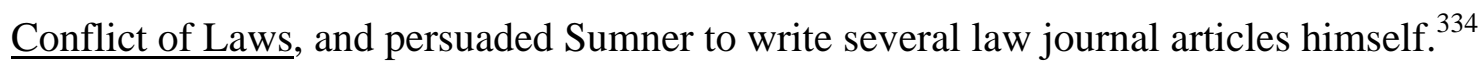

Later, when Sumner 's own law practice began to flounder, Story again came to the rescue and arranged an appointment as Reporter to the United States Circuit Court and also hired Sumner to edit and publish a collection of his legal decisions published under the title of "Sumner's Reports." During his absences in Washington on Supreme Court business, Story arranged for Sumner to teach his classes at Harvard Law School. ${ }^{335}$

After the friendship with Story cooled, Sumner fell under the influence of another such 'father-figure' Reverend William Ellery Channing. It was Channing, one of Boston's earliest reform leaders, who introduced Sumner to the social reform movement. Sumner adopted almost in toto Channing's views on abolitionism and other issues, especially Channing's opposition to the Garrisonians for their condemnation of the Constitution as a pro-slavery document. So close were Channing and Sumner that "When Channing died in 1842, Sumner felt his loss more deeply than he had the death of his own father." 336

${ }^{334}$ Donald, Sumner, 23, 24, 27, 2935 \& 36; Cason, 40 \& 42.

${ }^{335}$ After Sumner returned from Europe in 1840, his law practice continued to struggle. He again asked Story for help and Story arranged an appointment as U.S. Bankruptcy Commissioner. When Story took sick in 1840 and 1843, Sumner again taught his law classes. Donald, Sumner, 29-35, 48, 73-75, 82-84, 96; Cason, 45-6; 59; Sumner Works, vol. 1, vii-viii.

${ }^{336}$ Donald, Sumner, 85, 99-101, 133, 172; C.S. to Henry Wadsworth Longfellow, October 15, 1842, "C.S. to George Sumner" October 1842, both in Sumner Memoirs vol. II, 226-227. 
Sumner also sought the approval and support from males his own age. Among the numerous prominent individuals who became not only Sumner's life-long friends but political allies as well, were George T. Bigelow, Robert C. Winthrop, George S. Hilliard, James Freeman Clarke, Wendell Phillips, Samuel F. Smith, and Jonathan Stearns. ${ }^{337}$ One of Sumner's closest and most influential friends was Dr. Samuel G. Howe whom Sumner met in $1837 .{ }^{338}$

At about the same time that he met Howe, Sumner, together with his law partner George Hilliard, Cornelius C. Felton, noted poet, Henry Wadsworth Longfellow and Henry R. Cleveland, formed an informal social club that they called "The Five of Clubs" which met every Saturday evening for dinner and conversation. ${ }^{339}$ The members of "the Five of Clubs" became Sumner's closest friends and Sumner came to demand from them, and especially from Howe, "unquestioning love and admiration", devotion, loyalty, and "unqualified approval." In other words all of the things that Sumner never got from his father. ${ }^{340}$

There is little doubt that Sumner's relationship with his father profoundly affected his attitudes toward masculinity. His father's stern, unforgiving, and unnecessarily harsh,

${ }^{337}$ Pauline Holmes: A Tercentenary History of the Boston Public Latin School, 1635-1935 ("Harvard Studies in Education," Vol. XXV; Cambridge: Harvard University Press; 1935), 192, 194, 269-71, as cited in Donald, Sumner, 8, 9 -11 \& 16; Cason, 18-21, 23-25; James Brewer Stewart, Wendell Phillips, Liberty's Hero (Baton Rouge: Louisiana State University Press, 1986) 9; Donald, Sumner, 16, 81; C.S. to Jonathan Stearns, September 25, 1831, 83-83; C.S. to John B. Kerr, August 14, 1833, 121 both in Sumner Memoirs vol. I.

${ }^{338}$ Donald, Sumner, 85-87, 173; Harold Schwartz, Samuel Gridley Howe, Social Reformer, 1801-1876, (Cambridge, Massachusetts: Harvard University Press, 1956) 107.

${ }^{339}$ Cleveland was later replaced by Howe. Donald, Sumner, 16, 21, 39-40, 68-73, 76, 86; Cason, 47, 57-58; Newton Arvin, Longfellow: His Life and Work, (Boston: Little, Brown \& Company, 1962) 52; Cecil B. Williams, Henry Wadsworth Longfellow, (New York: Twayne Publishers, Inc., 1964) 17; Schwartz, Howe, 107.

${ }^{340}$ Sumner's mother, Relief Jacobs Sumner, was described by acquaintances as being nearly as stern as her husband. However the fact that she later bailed Charles out of his financial difficulties indicates that she must have had a softer side as well. Arvin, Longfellow:, 52; Williams, Longfellow, 17; Henry Adams, The Education of Henry Adams: An Autobiography (New York: The Modern Library, 1999) 29; Donald, Sumner, 76, 153, 174. 
personality led Sumner, like many of his fellow reformers, to question traditional norms of masculinity. In this regard Sumner was also influenced by the efforts of William Jay, Henry Ward Beecher, Gerrit Smith, William Lloyd Garrison, and other reformers to formulate a "nonaggressive" form of masculinity. ${ }^{341}$ Certainly the affection and loyalty that Sumner felt toward his friends, especially toward the member of the Five of Clubs, spoke directly to the ideal of "fraternal love" that Smith, Beecher, and Garrison touted as an ideal of their new form of masculinity. $^{342}$

But at the same time it is worth noting that Sumner never attained the level of trust and intimacy with women, that he did with men. That is not to imply that Sumner did not like women or that he was not attracted to women. On the contrary, Sumner held very sentimental and romantic notions about love, marriage, and family, and possessed very strong opinions on matters of domestic relations. He thought that women should know their roles and that a woman's place was at home. But at the same time Sumner did not relate well to women. He found communication with women difficult and he never really showed much interest in pursuing a romantic relationship with any of the number of eligible young women with whom he became acquainted over the years. ${ }^{343}$

Given Sumner's apparent lack of interest in women, questions naturally arise regarding Sumner's sexuality: specifically was Sumner heterosexual or homosexual? At this late date the question cannot be answered with certainty. Given Sumner's attitude toward women and the fact

\footnotetext{
${ }^{341}$ Griffin Wolff, "Masculinity," 597-602, passim.

${ }^{342}$ Griffin Wolff, "Masculinity,” 600.

${ }^{343}$ C.S. to Jane Sumner, March 4, 1834, in Sumner Memoirs, 97; Donald, Sumner, 38 \& 90.
} 
that he idolized older men, plus the fact that his closest friends were all men and that he unquestionably preferred the company of men, the possibility that Sumner was homosexual cannot be dismissed out of hand. But the evidence is far from convincing. An equally plausible explanation is that Sumner was asexual. Given his almost obsessive dedication to the cause of abolitionism Sumner may simply have found women to be an unwanted distraction from what he saw as his "mission." 344

But the most reliable indicator of Sumner's views concerning masculinity and the influence of masculinity on his life and career are his actual speeches and writings. Sumner, like Brooks, Davis, Lincoln, and other politicians of their age, often found it necessary to frame his speeches in the language of antebellum masculinity. The degree to which Sumner found it useful, or even necessary, to appeal to antebellum notions of masculinity was clear indication of not only his audience's preoccupation with those notions but also of the fact that Sumner himself had at least a theoretical understanding of antebellum masculinity. And indeed Sumner's speeches contained many references, both overt and covert, to antebellum masculinity. An early example of this can be found in Sumner's 1845 Fourth of July address "The True Grandeur of Nations." In the speech Sumner strongly criticized $19^{\text {th }}$ century American militarism and in so doing directly invoked the ethos of "feminized masculinity." Sumner argued that the "true grandeur of nations" did not lie in warfare, but "in moral elevation, enlightened, and decorated by the intellect of man ... can there be in our age any peace that is not honorable, any war that is not dishonorable."345

\footnotetext{
${ }^{344}$ Donald, Sumner, 70, 88-90; Schwartz, $\underline{\text { Howe, } 108 .}$

${ }^{345}$ Charles Sumner, “The True Grandeur of Nations” Sumner Works, Vol. 1, 9; Claude Moore Fuess, Daniel
} 
Sumner touched on this antimilitarism theme again in a speech entitled "The War System of the Commonwealth of Nations" that he delivered at a May, 1849 meeting of the American Peace Society in which he said:

The Cause of Peace does not depend upon any reconstruction of the human character, or upon holding in check the natural laws of man's being--but that it deals with man as he is, according to the experience of history--and, above all, that our immediate and particular aim the abolition of the Institution of War, and of the whole War System, as established Arbiter of Right in the Commonwealth of Nations, is as practicable as it would be beneficent. $^{346}$

While he criticized all aspects of aggressive masculinity, whether they originated in the

North or the South, Sumner directed his harshest criticisms at the South. Skilled rhetorician that

he was, Sumner knew exactly how to phrase his criticisms, often turning their own notions of masculinity against them and in so doing not only undermined southerners' arguments but challenged their sense of male identity as well. A good example of this occurred in a June, 1854, speech in which Sumner, in order to bolster his argument that there was no constitutional requirement to enforce the Fugitive Slave Act, made reference to Andrew Jackson's veto message of the 1832 Bank bill which read "Each public officer, who takes an oath to support the Constitution, swears that he will support its as he understands it, and not as it understood by others." 347 What better weapon could there be in this war of words than to use against them the

Webster, vol. 1 (Hamden, Connecticut: Archon Books, 1963), 295; Messerli, Mann, 448; Story strong disagree with the sentiments express in the speech and argued that in some cases war was "not only justifiable, but an indispensable part of public duty." Story went on to say, "In many parts of your discourse, I have been struck with the strong resemblence(sic) which it bears to the manly, moral enthusiasm of James Mackintosh, but I think that he would have differed from you in respect to war. Story to Sumner, August 11, 1854, Life and Letters, Story, ed., 544.

${ }^{346}$ Sumner, "The War System of the Commonwealth of Nations," Sumner Works, Vol. 2, 334.

${ }^{347}$ Charles Sumner, "Reply to Assailants, Oath to Support the Constitution: Weakness of the South from Slavery," June 28, 1864, Sumner Works vol. 4, " 179. 
words of the man whom southerners themselves characterized as the embodiment of southern manhood. $^{348}$

But most of Sumner's criticisms of the South revolved around slavery. Sumner believed that slavery had turned the South into a region of the starkest barbarism. In a direct refutation of southern claims that slavery exerted a civilizing influence on whites and blacks alike, Sumner boldly declared southern slavery to be "the greatest organized Barbarism on which the sun now looks down, without a single peer."349

According to Sumner there were several characteristics that rendered slavery barbaric. First, slavery was blasphemous in that it claimed "property in man."350 Secondly, slavery undermined marriage, an institution recognized by the church as a sacrament, both in its nonrecognition of slave marriages, and in the damage that it did to white marriages. ${ }^{351}$ Under slavery the bonds of affection between slaves counted for little in comparison to "the selfish interests or more selfish lust of those whose license knows no check." In this way "Stripped of every defence(sic), the chastity of a whole race is exposed to violence (and) delivered over to prostitution and concubinage"352

${ }^{348}$ Freehling, The Road to Disunion, 262-263, 266.

${ }^{349}$ Charles Sumner, "The Barbarism of Slavery," Washington D.C. June 4, 1860, 137 accessed through Legal Online Website, <http.medicolegal.tripod.com/sumnerbarbarism.htm.> Accessed on March 11, 2006. .

${ }^{350}$ Ibid., 131.

${ }^{351}$ Ibid., 131, 132.

${ }^{352}$ Ibid., 132, 133. 
Third slavery threatened families, through the selling of children away from parents and parents away from children. ${ }^{353}$ In this way was destroyed an important civilizing institution: "By the Law of Slavery, the parental relation is set at nought, and in its place is substituted the arbitrary control of the master (by which) children are swept unto the hammer of the auctioneer." $^{354}$

In all of these elements slavery was of course completely at variance both with biblical principles and with the very values and institutions that slavery's defenders claimed that it existed to protect. Rather than producing gentlemen, slavery turned men into brutes. Slaves were reduced "to the condition of beasts" and masters rendered little more than sex-crazed fiends. Thus was "man, supremest(sic) creature of earth, and first of God's works, despoiled of manhood and changed to a thing." 355

But what was perhaps the most unexpected, even shocking of Sumner's criticism of slavery was his assertion that what really made American slavery barbarous was the fact that in its most essential elements slavery had been derived "from Africa, ancient nurse of monsters,from Guinea, Dahomey, and Congo. . . .African barbarism was the beginning of American Slavery." ${ }^{356}$

Thus are barbarous prerogatives of barbarous half-naked African chiefs perpetuated in America by Slave-Masters, while the Senator from Virginia (Mr. Mason), perhaps unconscious of their origins is desirous to secure for them the appearance of a less barbarous pedigree, tricks them out with a phrase of the Roman Law, discarded by the

\footnotetext{
${ }^{353}$ Ibid., 131.

${ }^{354}$ Ibid., 133-134.

${ }^{355}$ Ibid., 137.

${ }^{356}$ Ibid., 140.
} 
Common Law, which simply renders into ancient Latin an existing rule of African Barbarism, recognized as an existing rule of American Slavery. ${ }^{357}$

This passage, while shocking and blatantly racist, was clearly intended to strike directly at the heart of southerners' pride and their egos and was also indicative of Sumner's ability to exploit southern notions of manhood. But it also illustrated the larger point that despite his somewhat dubious opinion of aggressive masculinity, Sumner was not above appealing to such notions when it served his purpose. In the same speech in which he invoked Jackson's Veto Message, Sumner vigorously attacked the southern warrior tradition and specifically the assertion of South Carolina Senator Andrew Butler that the southern colonies, and not the northern colonies, had been primarily responsible for winning the War of Independence. Sumner countered Butler's argument by citing several episodes, such as Ethan Allen's capture of Fort Ticonderoga, as evidence that Northern courage had been the dominant element in winning the war. He also cited a host of statistics that suggested that the North, by a margin of 249,463 to 146,675, had contributed almost twice as many soldiers to the war effort as the South. While the accuracy of these figures is open to question the point is that Sumner felt confident in citing them as evidence of a Northern warrior tradition. ${ }^{358}$

Sumner's purpose in trying to establish this northern warrior tradition was obvious, it was an attempt to rally the Northern public and inspire them to stand up to the South. Sumner obviously saw southerners as aggressive and opportunistic. Unless northerners showed firmness

\footnotetext{
${ }^{357}$ Ibid., 141.
}

${ }^{358}$ So powerful was Sumner's speech, that Ohio Senator Salmon Chase was moved to say "You have struck slavery the strongest blow it ever received: you have made it reel to the center." Sumner, "Reply," 198-204, passim; New York Daily Times June 27, 1854, quoted in Sumner "Reply" vol. 4, 178. 
and presented a united front against them, southerners were certain to take advantage of their weakness and to demand greater and greater concessions from both the North and from the federal government. ${ }^{359}$ Sumner's efforts to unite northerners in resistance to the aggressive "Slave Power" can be traced to a June, 1848, campaign rally of "Conscience Whigs" in Worcester Massachusetts, at which Sumner warned his audience that: ${ }^{360}$

In the prosecution of its purposes, the Slave-Power has obtained the control of both the great political parties. Their recent nominations (for president) were made to serve its interests, to secure its supremacy, and especially to promote the extension of slavery. Whigs and Democrats, I use the old names still--professing to represent conflicting sentiments, concur in being representative of the Slave Power. . . Though nominated by different parties, they (presidential candidates Lewis Cass and Zachary Taylor) represent, as I have said, substantially the same interest,-the slave-power. The election of either would be a triumph of the slave-power, and entail upon the country, in all probability, the sin of extending slavery. How, then, shall they be encountered? It seems to me in a very plain way. The lovers of freedom, of all parties, and irrespective of all party association, must unite, and, by a new combination congenial with the constitution, oppose both candidates. This will be the FREEDOM POWER, whose single object shall be to resist the SLAVE POWER. We will put them face to face, and let them grapple. Who can doubt the result. ${ }^{361}$

In September, 1854, Sumner delivered a speech at the first Republican State Convention

held at Worcester, Massachusetts entitled: "The Duties of Massachusetts at the Present Crisis.”

In this speech Sumner challenged slavery opponents to defend their manhood and stand up to the South, exhorting his audience to battle with the forces of darkness:

${ }^{359}$ Sumner, “'Strike, But Hear,': Attempt To Discuss the Fugitive Slave Bill. Remarks in the Senate, on Taking Up the Resolution Instructing the Committee on the Judiciary to report a Bill for Immediate Repeal of the Fugitive Slave Act," July 27 and 28, 1852, and "Freedom National, Slavery Sectional Speech," August 26, 1852, both in Sumner Works, Vol. 3, 243-245 \& 265-366.

${ }^{360}$ Donald, Sumner, 162 \& 165; Cason, 97; Introduction, Sumner Works, Vol. 1, xi.

${ }^{361}$ Sumner, "Union Among All Men of All Parties Against the Extension of Slavery", Sumner Works, Vol. 2, 232-233. 
Lord Chatham once exclaimed that the time had been, when he was content to bring France to her knees; now he would not stop till he had laid her on her back. Nor can we be content with less in our warfare (i.e. on slavery). We must not stop till we have laid the Slave Power on its back. ${ }^{362}$

Sumner told his audience that in order to defeat slavery, Massachusetts had to elect men to Congress "who will not shrink from conflict with slavery, and also other men who at home in Massachusetts will not shrink from the same conflict . .when the slave-hunter appears." ${ }^{363}$ Should Northerners give in to the South's demands for slavery expansion into the western territories, or for strict enforcement of the Fugitive Slave Act, it would certainly encourage Southerners to make further demands. ${ }^{364}$ The only way to check slavery's expansion, the only way to end slavery was for Northerners to stand up to the South. According to Sumner, in order for slavery's opponents to triumph:

Three things are needed by our beloved Commonwealth, in all her departments of government,-the same three things which once in Faneuil Hall I ventured to say were needed by every representative of the North at Washington. The first is backbone; the second is BACKBONE and the third is BACKBONE. ${ }^{365}$

Nor was Sumner content to merely spout advice to his fellow northerners or to exhort them to stand up to the South, he was fully prepared, even eager, to personally take the lead in defying southern aggression. When it came to speaking out on the things in which he believed, Sumner was not about to allow himself to be silenced by southern threats or by congressional gag orders. In fact the record of Sumner's service in the Senate is filled with incidents in which

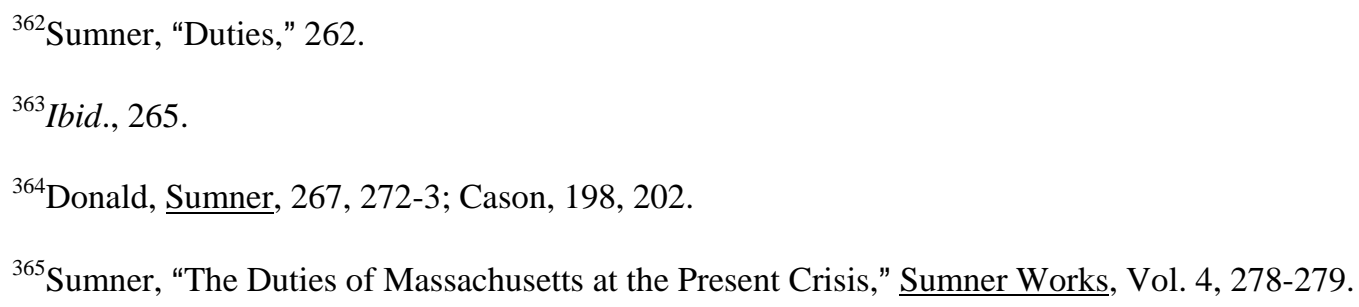


Sumner boldly, even aggressively, stood up to southern attempts at intimidation. In February, 1854, during the debate over the Kansas-Nebraska Bill, Sumner sternly warned the bill's sponsor Stephen Douglas and its southern supporters that the Kansas-Nebraska Act would never settle the slavery issue, declaring that "nothing can be settled which is not right."366 After the KansasNebraska Act was signed into law, Sumner predicted that the bill would have the direst consequences, and declared it: ${ }^{367}$

at once the worst and the best which Congress ever act. . . It is the worse bill, inasmuch as it is a present victory of Slavery . . It is the best bill on which Congress ever acted; for it ... annuls all past compromises with Slavery, and makes all future compromises impossible. Thus it puts Freedom and Slavery face to face, and bids them grapple. Who can doubt the result? ${ }^{368}$

A few months later, in June1854, Sumner was asked by Senator Andrew Butler whether he (Sumner) would honor his Constitutional oath, should the situation arise, to return a runaway slave to its master, Sumner answered in language that was bound to provoke a reaction saying: "Is thy servant a dog, that he should do this thing?”369 Sumner went on to compare Butler's native South Carolina to a "kennel of bloodhounds . . . 'pawing to get free his hinder parts,' in pursuit of a slave. ${ }^{370}$

\footnotetext{
${ }^{366}$ Donald, Sumner,247, 249, 250; Cason, 175; Sumner, "The Land Mark of Freedom: No Repeal of the Missouri Compromise," Sumner Works, Vol. 4, , 94-95.

${ }^{367}$ Donald, Sumner,252, 254-57, 259; Cason, 180-181; McPherson, Battle Cry, 109 \& 125.

${ }^{368}$ Sumner, "Final Protest, For Himself and the Clergy of New England Against Slavery in Nebraska And Kansas. Speech in the Senate, on the Night of the Final Passage of the Nebraska and Kansas Bill," May 25, 1854, Sumner Works, Vol. 4, 148-149.

${ }^{369}$ Sumner, 262; Cason, 186, 188 \& 190.

${ }^{370}$ Sumner, "Reply," 180.
} 
Even after the Kansas-Nebraska Act had been passed by Congress and signed into law, Sumner refused to give up the fight but continued to stand up in defiance of the "Slave Power." Throughout 1854 and 1855 Sumner gave speech after speech condemning both the KansasNebraska and the Fugitive Slave Acts. A February 23, 1855, speech before the Senate in which Sumner called for the repeal of the Fugitive Slave Act, led to the following confrontation between Sumner and Andrew Butler: "I will ask the gentleman one question" stated Butler, "If it devolved upon him as a representative of Massachusetts, all federal laws being put out of the way, would he recommend any law for the delivery of a fugitive slave under the Constitution of the United States?" Sumner answer was simple yet bold: "NEVER!." 371

Of course Sumner's determination to stand up to the South and his belief in the need for northerners to be firm in their dealings with southerners and not show weakness was heavily influenced by northern stereotypes of southerners as being either poor, ignorant, 'crackers' or arrogant, prideful, planter-aristocrats who, being used to being obeyed by their slaves, were full of bluster, but who when confronted with firmness always backed down. ${ }^{372}$ That Sumner shared these biased views of southerners is evidenced by a speech that Sumner gave on May, 25, 1854, the same night that the Kansas-Nebraska Act won final congressional approval in which he viciously attacked both the southern people and southern institutions. Sumner took particular aim at Senators James Mason of Virginia and Andrew Butler of South Carolina, saying of them:

I think, Sir, that I am not the only person on this floor, who listening to these two selfconfident champions of that peculiar fanaticism of the South, was reminded of the

\footnotetext{
${ }^{371}$ Cason, 204; Sumner, "The Demands of Freedom; Repeal of the Fugitive Slave Act," Sumner Works, Vol. 4, 338-339.

${ }^{372}$ Ash, "Poor Whites," 40.
} 
striking words of Jefferson, picturing the influence of slavery, where he says "The whole commerce between Master and Slave is a perpetual despotism, on the one part, and degrading submission on the other. Our children see this, and learn to imitate it; . . . and thus nursed, educated and daily exercised in tyranny cannot but be stamped by it ... The man must be a prodigy, who can retain his manners and morals undepraved by such circumstances." Nobody, who witnessed the Senator from South Carolina or the Senator from Virginia in this debate, will place either of them among the "prodigies" described by Jefferson. $^{373}$

In the final assessment Charles Sumner would seem to have had little in common with the aggressive form of masculinity that was the norm for so many males of his time. Even as a youth Sumner had little interest in competitive sports, he drank very little, if at all; he did not chase women; and never touched tobacco, other than an occasional after-dinner cigar. Sumner did not even participate in most of the leisure activities that were associated with "aggressive" manliness: such as hunting, fishing, horse racing. Sumner certainly would not have been caught dead at a cockfight or boxing match. ${ }^{374}$

But there is no denying that Sumner was a man of courage. Although he never displayed the aggressive bravado or so-called "martial spirit" so often found in Southern males, Sumner displayed a "quiet sort of courage" that spoke louder than any duel or bare-knuckle brawl. Following the Anthony Burns incident, which the Democratic press attempted to blame on Sumner-calling him a "fanatical abolitionist-in addition to hostile editorials Sumner faced threats of violence, even murder. ${ }^{375}$ Sumner refused to be intimidated and continued to walk

${ }^{373}$ C.S. "Reply to Assailants, Oath to Support the Constitution: Weakness of the South from Slavery," June 28, 1864, Sumner Works vol. 4, 175-176; Thomas Jefferson, Notes on Virginia, Query XVII, as quoted in "Reply."

${ }^{374}$ Sumner occasionally drank wine, but almost never touched hard liquor. Donald, Sumner, 8, 37-38, 307.

${ }^{375}$ The incident in question involved an attack by a Boston mob upon the Court House where an alleged fugitive slave named Anthony Burns was being held in an attempt to free him. In the ensuing struggle a guard named James Batchelder, was killed. Sumner, "Final Protest, For Himself and the Clergy of New England Against Slavery in Nebraska And Kansas. Speech in the Senate, on the Night of the Final Passage of the Nebraska and 
alone and unarmed through the streets of Washington. In fact if anything Sumner seemed invigorated by the threats and increased his antislavery efforts. ${ }^{376}$

In the days leading up to his encounter with Brooks, Sumner received countless anonymous threats warning of the dire consequences that awaited him for his brazen insult to Southern honor. Yet through it all Sumner refused to alter his habits or moderate his rhetoric. Rather than being intimidated the threats seemed to embolden Sumner. He refused to even allow friends to escort him home. ${ }^{377}$ It is not too much to imagine that the fact that the threatened assaults failed to materialize, after the Burns incident, may have lulled Sumner into a false sense of security and led him to not take proper precautions. By so doing Sumner displayed another characteristic highly prized in antebellum males and especially in members of the political class: candor, the courage to speak one's mind regardless of the consequences. ${ }^{378}$

Furthermore, his actions in the encounter with Brooks were entirely in keeping with the image of the "Christ-like" martyr who represented, as abolitionists saw it, the highest form of masculinity, the man who "suffered serious injury, even death to defeat evil," who "took blows but who never returned them."379 For Sumner to have acted in any way other than he did act, in other words if he had tried to protect himself, and not fall victim to Brooks's attack, then he could not have acted out the role of martyr and would not have become the symbolic figure that

Kansas Bill," May 25, 1854, Sumner Works, Vol. 4, 148-149; Donald, Sumner, 260-261; Cason, 185.

${ }^{376}$ Cason, 186, 188, 190.

${ }^{377}$ Donald, Sumner, 260-61; Cason, 185.

${ }^{378}$ Etcheson, "Manliness," 62-63, 67-71; Ownby, Subduing Satan, 11-13, 126, 129, \& 134.

${ }^{379}$ Griffin Wolff, “Masculinity,” 600-602. 
so energized Northern public opinion against the barbarism of slavery. Just as John Brown "had better served the cause by failing and dying than he ever could have done by succeeding," so had Sumner better served the cause by playing the passive victim than he could have done by striking back:

To multitudes in the North, he seemed an embodiment of all the virtues, and to much of New England in particular a great hero, representing everything that was best in the intellect and character of the section. The literary power of his best speeches had given them a wide currency in England, had obtained a large sale for a compilation recently issued by Ticknor \& Fields, and had won the delighted applause of the free-soil press. ${ }^{380}$

${ }^{380}$ Recent Speeches and Addresses in Nevins, 438. 


\section{CHAPTER 5}

\section{THE CANING OF SUMNER}

With both House and Senate scheduled to adjourn early to mark the death of Representative John G. Miller, May 23, 1856, promised to be an uneventful day in the history of Congress. But just before one p.m. South Carolina Representative Preston Brooks approached the desk of Massachusetts Senator Charles Sumner, where he raised a gutta-percha walking stick with which he began to beat Sumner senseless. ${ }^{381}$ To the modern observer this incident, known to history as the "Caning of Sumner," seems little more than an act of savagery (as it did to many nineteenth century observers). The question then, as now, was what could have provoked such brutality?

The immediate provocation was a speech that Sumner had delivered a few days before in the Senate Chamber entitled "The Crime Against Kansas" in which Sumner delivered a scathing attack on Brooks's kinsman, Senator Andrew Butler of South Carolina, referring to him with such shockingly vivid and insulting terms as "Don Quixote of Slavery" and "mad zealot" of "tyrannical sectionalism." The code of Southern honor demanded that such an attack not go unpunished. Senator Butler, being old and infirm, could hardly be expected to chastise Sumner himself. Therefore Brooks, as an avid devotee of Southern honor, saw it as his duty to defend his family's good name. ${ }^{382}$

${ }^{381}$ Alleged Assault Upon Senator Sumner (House Report No. 182, 34th Congress, First Session; hereafter Sumner Assault), 26, 27, 35, 57; Congressional Globe, Vol. I, 292; Sumner, Works, Vol. IV, 269. Proceedings of the Massachusetts Historical Society, (hereafter Proceedings) LXI, 220; David Herbert Donald, Charles Sumner and the Coming of the Civil War (New York: Alfred A. Knopf, 1960), 291-94.

${ }^{382}$ Charles Sumner, "The Crime Against Kansas:" Speech of Charles Sumner of Massachusetts, In the Senate of the United States, May 18, 1856; http://www.furman. edu/benson/ docs/summerksk2.htm. pg 3; Congressional Globe, Appendix, 886; "Preston Brooks to J. H. Brooks," May 23, 1856" as quoted in Robert L. 
But in a larger sense, the origins of the attack were rooted in the violence then raging in Kansas territory between rival pro-slavery and anti-slavery factions. The violence in Kansas can be counted as an indirect consequence of the War with Mexico of 1846-1848 and the acquisition of vast territories in the Southwest that resulted from that war. With the admission of California, and later Oregon, to statehood many within and outside Congress began to call for the construction of a transcontinental railroad to better facilitate communication between the East and West. But where to place its eastern terminus? Northerners favored Chicago; Southerners pushed for New Orleans, Memphis, or St. Louis. ${ }^{383}$

As Senator from Illinois, resident of Chicago, and leader of the Northern Democrats, Stephen Douglas naturally favored the northern route. Additionally Douglas was heavily invested in Chicago real estate and therefore could expect to realize a hefty profit should Chicago be selected. ${ }^{384}$ Unfortunately a northern route would run through unorganized Indian territory, an area once thought so devoid of arable land that it was referred to as the "Great American Desert." More recently, however, settlers had begun to show interest in the "fertile soil of the Kansas and Platte river valleys." But first the area had to be organized as a territory. Douglas, as Chairman of the Senate Committee on Territories, was in a strong position to solve

Merriwether (ed.) " Preston S. Brooks on the Caning of Charles Sumner”, South Carolina Historical and Genealogical Magazine, XII (1951), 2; Charles Sydnor, "The Southerner and the Laws," Journal of Southern History, Vol. VI (1940) 3-23; Jack Kenny Williams, "The Code of Honor in Antebellum South Carolina," South Carolina Historical Magazine (Vol. LVI (1953) 113-28; Donald, Sumner, 295; James M. McPherson, Battle Cry of Freedom: The Civil War Era (New York: Ballantine Books, 1988), 122 \& 150.

${ }^{383}$ McPherson, Battle Cry, 108; Potter, Impending Crisis, 146-48; Nicole Etcheson, Bleeding Kansas, Contested Liberty in the Civil War Era, (Lawrence, Kansas: The University of Kansas Press, 2004) 12..

${ }^{384}$ McPherson, Battle Cry, 108; Potter, Impending Crisis, 149-150, 153-54; Etcheson, Bleeding Kansas, 9; William W. Freehling, The Road to Disunion: Secessionists at Bay, 1776-1854 (New York: Oxford University Press, 1990). 537-38. 
this problem. In January, 1854, he introduced a bill to organize the new territory. It would be known as Nebraska. ${ }^{385}$ To pass, the bill needed the support of at least six southern senators who would oppose his bill because the area in question lay north of the Missouri Compromise line of 36* 30, ${ }^{386}$ The most powerful southern voting bloc, a group of four senators, including Andrew Butler, who called themselves the "F Street Mess", made it clear to Douglas that the price of passage for the Nebraska bill was repeal of the Missouri Compromise's ban on slavery north of $36 * 30,{ }^{387}$

Douglas knew that the North would never agree to that, so to make the bill more palatable to Southerners he inserted some ambiguous language into the bill which said that Nebraska would be organized 'with or without slavery' as its constitution might dictate. When Southerners demanded more, Douglas specified that popular sovereignty would be the basis of "all questions pertaining to slavery in the territories." ${ }^{388}$ Douglas then went even further and added an additional provision that split the territory in two: the northern half would still be called Nebraska, but the southern half would now be known as Kansas. Since the soil and climate in

\footnotetext{
${ }^{385}$ McPherson, Battle Cry, 121; Potter, Impending Crisis, 151; Etcheson, Bleeding Kansas, 9-12; Freehling, Road, 546-47.

${ }^{386}$ McPherson, Battle Cry, 121 \& 122; Potter, Impending Crisis, 152; Etcheson, Bleeding Kansas, 12-13.

${ }^{387}$ The "F Street Mess" included, Andrew Butler, Chairman of the Judiciary Committee, James M. Mason, Chairman of the Foreign Relations Committee, Robert M.T. Hunter, Chairman of the Finance Committee, and David Atchinson President Pro-tem. McPherson, Battle Cry, 122; Potter, Impending Crisis, 156; Eric Foner, Free Soil, Free Labor, Free Men, The Ideology of the Republican Party Before the Civil War, (New York: Oxford University Press, 1995), 5; Freehling, 551.

${ }^{388}$ Potter, Impending Crisis, 159; McPherson, Battle Cry, 123; Freehling 552-53.
} 
Kansas were similar to those of Missouri, its slave-owning neighbor to the east, it seemed plausible that slavery could take root there. ${ }^{389}$

The Kansas-Nebraska Act brought a firestorm of criticism down upon Douglas's head. To many Northerners, Douglas had committed an act of treason against the North. One of the angriest expressions of this Northern rage was an editorial in the January 19, 1854, National Era, entitled the "Appeal of the Independent Democrats." Authored by Salmon P. Chase, Charles Sumner, Gerritt Smith, and other antislavery leaders, the "Appeal” condemned the KansasNebraska Act as "a gross violation of a sacred pledge" and "an atrocious plot to . . convert (Kansas) into a dreary region of despotism, inhabitated by masters and slave:"390

Nothing is more certain than that this prohibition has been regarded and accepted by the whole country as a solemn compact against the extension of slavery into any part of the territory acquired from France lying north of 36*30'. ${ }^{391}$

Despite the strenuous objections of Chase, Sumner, and other Northerners, Douglas managed to push the Kansas-Nebraska Act through Congress and Pierce signed it into law on May 31, $1854 .^{392}$

No piece of legislation in American history has had such a dramatic impact as the Kansas-Nebraska Act. First of all it caused a fatal split between the Northern and Southern

${ }^{389}$ McPherson, Battle Cry, 123; Potter, Impending Crisis, 159-61; Etcheson, Bleeding Kansas, 14-16; Freehling, 55-59; Robert N. Johannsen, Stephen A. Douglas, (New York: Oxford University Press, 1973) 402-405.

${ }^{390}$ McPherson, Battle Cry, 123 \& 124; Potter, Impending Crisis, 162-64; Etcheson, Bleeding Kansas, 16-17; Foner, Free Soil, 96; Freehling, 558-59.

${ }^{391}$ S.P. Chase, Charles Sumner, J.R. Giddings, Edward Wade, Gerritt Smith, \& Alexander De Witt, "Appeal of the Independent Democrats" National Era, January, 19, 1854; library.stritch.edu/blackhistorymonth/ PDFS/APPEAL\%20OF\%20THE\%20INDEPENDENT\%20DEMOCRATS.pdf. $166-67$.

${ }^{392}$ McPherson, Battle Cry, 109, 124 \& 125; Etcheson, Bleeding Kansas, 16-20; Potter, Impending Crisis, 
wings of the Whig party that ultimately led to that party's demise and its eventual replacement by the Republicans. ${ }^{393}$ Secondly in the fall 1854 elections the Democrats lost control of all but two Northern state legislatures as well as 70 seats in the House of Representatives and with them control of Congress. More than anything else the election of 1854 was a personal rebuke to Stephen Douglas who was heckled off a Chicago stage when he went back to Illinois to campaign for fellow Democrats. ${ }^{394}$

But the most dreadful consequence of the Kansas-Nebraska Act was of course "Bleeding Kansas." As soon as the bill was signed, settlers from both North and South began pouring into Kansas. Having failed to prevent the passage of the Kansas-Nebraska act, slavery opponents decided to do the next best thing: exploit it. Therefore, in the summer of 1854 antislavery activists formed the New England Emigrant Aid Company (hereafter N.E.E.A.C.) to facilitate the "free soil settlement of Kansas." The free soil settlers were soon outnumbered by pro-slavery settlers moving in from neighboring Missouri. ${ }^{395}$

In the fall of 1854, territorial Governor Andrew Reeder called for the election of a delegate to Congress. In a blatant attempt to steal the election Senator David Atchison of Missouri, quasi-leader of the pro-slavery settlement movement, began to lead bands of Missouri "border ruffians" into Kansas. In the first of a series of irregular elections, in which both sides

${ }^{393}$ McPherson, Battle Cry, 110, 125-6, 130-8, 140-44; Potter, Impending Crisis, 247-48; Etcheson, Bleeding Kansas, 20-23; Foner, Free Soil, 127-129; Freehling, 562.

${ }^{394}$ McPherson, Battle Cry, 129-30.

${ }^{395} \mathrm{By} 1856$ the free soil settlers, most of whom actually came from the Mid-West, would be in the majority. McPherson, Battle Cry, 145; Potter, 205, 214, 218, 224; Etcheson, Bleeding Kansas, 37-49 passim; Freehling, 5645. 
engaged in massive election fraud, Atchison and his partisans carried the day. ${ }^{396}$ But the situation in Kansas remained so unsettled that by January 1856 there were two rival governments: an "official" (proslavery) one at Lecompton and a rival free-soil government at Topeka. ${ }^{397}$ With two rival governments contending for control of the territory, both armed to the teeth and neither willing to yield, a clash of arms was inevitable. In May, 1856, when a proslavery posse sacked the "free-soil stronghold" of Lawrence, Kansas exploded into an all-out guerrilla war that would earn for the territory the sobriquet of "Bleeding Kansas.”398

1856 being a presidential election year, both parties sought to exploit "Bleeding Kansas" for all the propaganda value that it was worth. It was within the context of the ensuing debate that Charles Sumner gave the "Crime Against Kansas" Speech and Preston Brooks launched his subsequent attack. Douglas fired the first salvo in this war of words. On March 12, 1856, he presented the Democratic version of events, in which peaceful proslavery immigrants from Missouri had come legally to Kansas to set up a territorial government modeled, naturally enough, on the proslavery constitution of their native Missouri. Unfortunately their plans were shattered by the illegal plotting of the New England Emigrant Aid Company, "an abolitionist

${ }^{396}$ At one point during 1855, Senator Atchinson while preparing to lead a band of border ruffians into Kansas, declared to his followers that "There are 1100 men coming over from Platte County to vote and if that ain't enough we can send 5000-enough to kill every goddamned abolitionist in the Territory." McPherson, Battle Cry, 145-7; Potter, 201-5; Etcheson, Bleeding Kansas, 53-54, 55, 56.

${ }^{397}$ For a more detailed account of the territorial elections, see McPherson, Battle Cry of Freedom, 145-8; Potter, 206; Etcheson, Bleeding Kansas, 73-75.

${ }^{398}$ The town of Lawrence was named for Amos Lawrence, chief financier of the N.E.E.A.C. McPherson, Battle Cry, 148; Potter, 206-207, Etcheson, Bleeding Kansas, 79, 85-86, 104-105, 122; Potter, Impending Crisis, 207-209; Nevins, Ordeal, II, 475. 
conspiracy, (that) had brought in hordes of antislavery men, armed with Sharps rifles and pledged to use them against the peaceful Southerners." 399

Northerners fired right back. The first to respond was New York Senator William A. Seward, who had took the floor on April 9, 1856, in defense of the Kansas free soil movement. In Seward's version of events, which was no less distorted than Douglas's for being its polar opposite, the free-soilers were innocent victims who were only seeking to set up a territorial government "in the manner prescribed by Congress." It was the Missourians who had invaded Kansas and, through fraud, terror and outright murder, usurped control of its nascent territorial government for "the expressed purpose of establishing slavery as a permanent institution within the territory." ${ }^{400}$ Even worse than President Pierce's failure to stop the invasion was the fact that he had been: "an accessory to these political transactions ... He has adopted the usurpation, and made it his own, and he is now maintaining it with the military arm of the republic."401

Next came Senator Sumner. Sumner, who was receiving accounts of the Kansas atrocities from various Free Soil organizations, had been working on a response to Douglas for months and had borrowed heavily from the Library of Congress for material with which to bolster his arguments. Sumner's research paid off handsomely when he took the floor on May

\footnotetext{
${ }^{399}$ Donald, Sumner, 278-80.
}

${ }^{400}$ William A. Seward, "Memoir, Biographical and Historical." The Works of William H. Seward 5 Vols. (Hereafter Seward Works) George Baker ed., IV. (Boston, Mass.; New York: Houghton, Mifflin \& Co., 1884) 39; Donald, Sumner, 281; Glyndon G. Van Deusen, William Henry Seward, (New York: Oxford University Press, 1967) 169. 281.

\footnotetext{
${ }^{401}$ William A. Seward, "The Immediate Admission of Kansas”, Seward Works, 479-481; Donald, $\underline{\text { Sumner, }}$
} 
19, 1856, and the crowds of onlookers who filled the Senate galleries that day heard one of the most memorable speeches in the history of the Senate: "The Crime Against Kansas.”402

Sumner's speech would be more than a rebuttal of Douglas's arguments, it would express all of Sumner's thoughts and feelings regarding the evils of slavery. But above all Sumner's speech was to be an exposition of the monstrous crime being committed in Kansas. ${ }^{403}$ Like Seward, Sumner saw Kansas as a peaceful, if unsettled, land populated by industrious, lawabiding free-soil settlers who had been viciously attacked by Missouri border ruffians. The border ruffians enjoyed not only the support but also the protection of the proslavery President Franklin Pierce. The speech would be an indictment of not only Pierce but also of the opportunistic politicians who had benefitted from this "reign of terror," including Douglas, James Mason, Chairman of the Senate Foreign Relations Committee, Stephen Douglas, and especially, Andrew Butler. ${ }^{404}$ If the speech contained little that was new in regard to the situation in Kansas, it did contain some extremely stirring rhetoric with references to such heroes of antiquity as Verres, Catiline, Demosthenes, Cicero, and Sumner's comparisons of the pro-slavery settlers' actions with such atrocities as the looting of Sicily by the Romans. ${ }^{405}$

The speech lasted two days, May 19-20 and, as Sumner said, covered not only the crime, but "the apologies for the crime" and "the true remedy." Speaking in the flowery and verbose

\footnotetext{
${ }^{402}$ Congressional Globe, $34^{\text {th }}$ Congress, $1^{\text {st }}$ session. Appendix, 545; Donald, Sumner, 281-283; Nevins, 437439.

${ }^{403}$ Donald, Sumner, 281 \& 282.

${ }^{404}$ Donald, Sumner, 278-281; McPherson, Battle Cry, 149.

${ }^{405}$ Charles Sumner, "The Crime Against Kansas: The Apologies for the Crime: The True Remedy" Speech of Charles Sumner of Massachusetts, In the Senate of the United States, May 18, 1856. http://www.furman.edu/ 〜benson/docs/summerksk2.htm. pg 1-2; Nevins, 439.
} 
style of the time, Sumner began by reminding those assembled that they had been "called to redress a great transgression." He then launched into a litany of events in Kansas, describing them as "the rape of a virgin territory, compelling it to the hateful embrace of Slavery" which may be "clearly traced to a depraved longing for a new slave State . . . in the hope of adding to the power of Slavery in the national government." ${ }^{406}$ In order to secure its position in Kansas, the 'Slave Power' had corrupted public opinion "through venal pens and prostituted press" and had made tools of public officials, "from President to the lowest border postmaster." Furthermore, this campaign of usurpation and corruption had been carried out with "an audacity beyond that of Verres, a subtlety beyond that of Machiavel (sic), a meanness beyond that of Bacon, and an ability beyond that of Hastings." ${ }^{407}$

Turning from the crime to the criminals, Sumner described the invading Missourians as being "murderous robbers ... Hirelings, picked from the drunken spew and vomit of an uneasy civilization in the form of men" who were "leashed together by secret signs and secret lodges, and who (have) renewed the incredible atrocities of the Assassins and the Thugs." ${ }^{" 408}$ In their desire to secure a foothold for slavery in Kansas, these armed interlopers had both elected an illegal, proslavery, legislature, and adopted an illegal, proslavery, constitution. "Thus, by tyrannical forethought, the usurpation not only fortified all that it did, but assumed a selfperpetuating energy." 409 Sumner then turned to assail the Pierce Administration that had

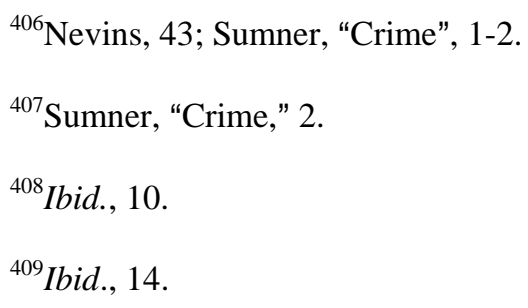


supported this "Usurpation." "Even now the black flag of the land pirates from Missouri waves at the masthead; in their laws you hear the pirate yell, and see the flash of the pirate knife, while, incredible to relate! the President, gathering the Slave Power at his back, testified a pirate sympathy." ${ }^{410}$

Sumner defended the actions of the Emigrant Aid Society without question. According to Sumner the Massachusetts legislature had chartered the society merely "for the purposes of directing emigration westward and aiding in providing accommodations for the emigrants after arriving in Kansas." ${ }^{411}$ That the society had hired anyone to go to Kansas; that it had supplied anyone with guns; that it had in any way "encouraged any fanatical aggression upon the people of Missouri" he flatly denied and insisted that it had "counseled order, peace, forbearance." Sumner even denied that it was "an abolition society."

Sumner also attacked the four apologies that pro-slavery forces had offered for the Crime against Kansas: the Apology tyrannical; the Apology imbecile; the Apology absurd; and the Apology infamous." The first, the Apology tyrannical was the product of Governor Andrew Reeder who had endorsed the "Usurping (pro-Slavery) Legislature." The second, the Apology imbecile, consisted of President Pierce's claim that he had "no authority to interfere in Kansas" a claim that Sumner rejected out of hand as ridiculous. ${ }^{413}$

\footnotetext{
${ }^{410}$ Ibid., 14.

${ }^{411}$ Ibid., 18.

${ }^{412}$ Ibid., 19.

${ }^{413}$ Ibid., 15.
} 
The third, the Apology absurd referred to an incident involving a free soil settler named George F. Warren, who had been captured while allegedly in possession of a copy of the "Constitution and Ritual of the Grand Encampment and Regiments" of a supposed free-soil paramilitary organization called the Kansas Legion. According to Sumner, the incident was a complete fabrication. No such organization as the Kansas Legion existed; the episode had been invented by pro-slavery forces as an excuse to "extenuate the Crime Against Kansas." ${ }^{414}$ Finally there was the Apology infamous which consisted of the various "false testimonies" that had been made against the Emigrant Aid Society:

Defying Truth and mocking Decency, this Apology excels all others in futility and audacity, while, from its utter hollowness, it proves the utter impotence of the conspirators to defend their crime. Falsehood, always infamous, in this case arouses peculiar scorn. An associate of sincere benevolence, faithful to the Constitution and laws, whose only fortifications are hotels, school-houses, and churches, whose only weapons are saw-mills, tools and books; whose mission is peace and good will, has been falsely assailed on this floor, and an errand of blameless virtue has been made the pretext for an unpardonable crime. Nay, more the innocent are sacrificed, and the guilty set at liberty. They who seek to do the mission of the Saviour are scourged and crucified, while the murderer, Barabbas, with the sympathy of the chief priests, goes at large. ${ }^{415}$

But Sumner saved his harshest words for those who he felt were the real criminals of

Kansas: Democratic Senators Andrew Butler of South Carolina, Stephen Douglas of Illinois, and James Mason of Virginia. Sumner began his verbal assault with Butler, who was absent in his native South Carolina, by dubbing him the "Don Quixote" of slavery. ${ }^{416}$

\footnotetext{
${ }^{414}$ Ibid., 17.

${ }^{415}$ Ibid., 18.

${ }^{416}$ Donald, Sumner, 285-7; 295; McPherson, Battle Cry, 122, 150.
} 
If Butler was the Don Quixote of slavery, Douglas was “ its very Sancho Panza, ready to do all its humiliating offices." Sumner went on to contend that Douglass: "In his recent labored addresses he had piled one mass of error upon another mass; he had arrogantly dreamed of subduing the North,"--but he would fail, for against he were arranged the human heart--"against him is God." 417 Douglas, listening to the speech at the rear of the Senate Chamber, angrily paced back and forth and was heard by at least one witness to mutter: "That damn fool will get himself killed by some other damn fool." ${ }^{418}$

But even worse was to come. The next day Sumner continued his attack upon Butler and ungraciously made use of a speech impediment from which the latter suffered. Referring to the South Carolina Senator's recent speech on Kansas, Sumner said that Butler had "with incoherent phrases, discharged the loose expectoration of his speech" upon the people of the Territory. Sumner went on to say that Butler "shows an incapacity of accuracy, whether in stating the Constitution or in stating the law, whether in the details of statistics or the diversions of scholarship. He cannot open his mouth, but their (sic) flies out a blunder." 419

Sumner then turned his attention to Butler's home state of South Carolina, declaring that if its entire history were blotted out: "civilization might lose . . .less than it has already gained by the example of Kansas, in its valiant struggle against oppression." He then went on to compare

\footnotetext{
${ }^{417}$ Sumner, "Crime," 4.

${ }^{418}$ Donald, Sumner, 285-6.

${ }^{419}$ Sumner, "Crime", 30.
} 
Kansans' stout courage in facing down the invading border ruffians with South Carolina's

"shameful imbecility from Slavery, confessed throughout the Revolution." 420

Sumner ended his speech with an attack on Douglas and Mason. Douglas, he labeled one of those "mad spirits who would endanger and degrade the Republic, while they betray all the cherished sentiments of the Fathers and the spirit of the Constitution, in order to give new spread to slavery." ${ }^{421}$ As for Mason:

He does not represent that early Virginia, so dear to our hearts, which gave to us the pen of Jefferson, by which the equality of men was declared, and the sword of Washington, by which independence was secured; but he represents that other Virginia, from which Washington and Jefferson now avert their faces, where human beings are bred as cattle for the shambles, and where a dungeon rewards the pious matron who teaches little children to relieve their bondage by reading the Book of Life. ${ }^{422}$

In a speech dripping with venom, these passages are particularly offensive, even to the modern reader. By now Sumner has abandoned any pretense of forensic analysis and is simply indulging in the basest sort of character assassination. Especially egregious were the references to Butler's speech impediment which did much to justify the judgment of scholars, then and now, that Sumner went too far. These passages certainly contributed nothing toward convincing others to accept the correctness of Sumner's arguments.

As might be expected, reaction to the speech was immediate and fierce. Democratic Senator Stephen Douglas delivered a stinging rebuke of Sumner and of the "libels (and) gross insults" that his speech contained, especially those directed at Butler and Atchison. In ruthlessly

\footnotetext{
${ }^{420}$ Ibid., 31.

${ }^{421}$ Ibid., 31.

${ }^{422}$ Ibid., 32.
} 
attacking the two men, neither of whom was present to defend himself, Sumner spit forth a "cool, deliberate malignity . . . upon men who differ from him-for that is their offense," leading Douglas to wonder what Sumner's purpose was in making the speech: "Is it his object to provoke some of us to kick him as we would a dog in the street, that he may get sympathy upon the just chastisement?" Or was Sumner trying "to drive men here to dissolve social relations with political opponents?"423

Then came Mason who declared that it was only his duty to his state and his respect for the Senate's rules that forced him to sit and listen to such "loathsome deformities in accusation and vilification" as were contained within Sumner's speech "The necessity of political position alone brings me into relations with men upon this floor who elsewhere I cannot acknowledge as possessing manhood in any form." Mason's meaning could not have been clearer: had Sumner's remarks been made anywhere but within the Senate Chamber, Mason's reaction would not have been limited to mere words. ${ }^{424}$ When Sumner tried to answer Mason's comments, an ugly exchange broke out between him and Douglas that further strained the limits of Senate decorum:

Sumner: "To the Senator from Illinois I should willingly leave the privilege of the common scold-the last word." (He should) "remember hereafter that the bowie-knife and bludgeon are not the proper emblems of senatorial debate ... I say, also, to that Senator . . . that no person with the upright form of man can be allowed-“

Douglas: "Say it."

Sumner: "I will say it. No person with the upright form of man can be allowed, without violation of all decency. To switch out from his tongue the perpetual stench of offensive

${ }^{423}$ Congressional Globe, $34^{\text {th }}$ Congress, $1^{\text {st }}$ session, Appendix, 544-7; Nevins, Ordeal, II, 442.; Donald, Sumner, 286-287.

${ }^{424}$ Congressional Globe, $34^{\text {th }}$ Congress, $1^{\text {st }}$ session, Appendix, 544-7; “The Crime Against Kansas" Charles Sumner: His Complete Works, (20 Volumes) (Boston: Lee and Shepard, 1900) (hereafter Complete Works) Vol. 5, 249; Donald, Sumner, 286-7. 
personality ... The noisome, squat, and nameless animal, to which I now refer, is not the proper model for an American Senator. Will the Senator from Illinois take notice?"

Douglas: "I will, and therefore will not imitate you, sir."

Sumner: "Mr. President, again the Senator has switched his tongue, and again he fills the Senate with its offensive odor."

Sumner then turned on Mason and lectured the Virginia Senator like a dull school boy: "hard words are not argument; frowns not reasons; nor do scowls belong to the proper arsenal of parliamentary debate" to which Mason could only feebly respond: "The Senator is certainly non compos mentis."

Even Republicans found Sumner's remarks objectionable. Edward Everett declared that "Language equally intemperate and bitter is sometimes heard from a notorious parliamentary blackguard, but from a man of character of any party I have never seen any thing so offensive." ${ }^{427}$ But the strongest condemnations came from Democrats and especially Southern Democrats. Lewis Cass, of Michigan, condemned the speech as "the most un-America and unpatriotic that ever grated on the ears of the members of this high body." ${ }^{428}$

But while nearly all Democrats, Northern as well as Southern, were outraged by Sumner's verbal assault, none were more outraged than Preston S. Brooks. A second term representative from the same district that had elected John C. Calhoun, Brooks was a 36-year-old

${ }^{425}$ Congressional Globe, $34^{\text {th }}$ Congress, $1^{\text {st }}$ session, (hereafter Cong. Globe) Appendix, 544-7; "The Crime Against Kansas, Complete Works, Vol. 5, 254-256.

${ }^{426}$ Donald, Sumner, 288.

${ }^{427}$ Cong. Globe, Appendix, 664; Donald, $\underline{\text { Sumner, }} 288$.

${ }^{428}$ Cong. Globe, Appendix, 631-2; Sumner Assault, p. 66; American Archives, $4^{\text {th }}$ Series, Vol. I, col. 466, as cited in "The Crime Against Kansas" Complete Works, Vol. 5, 249; McPherson, Battle Cry, 150-152. 
Mexican War veteran with a reputation for being a moderate. In fact Brooks's conduct during the debates over the Kansas-Nebraska Act had been so measured that he had drawn criticism from his fellow Carolinians for being "a little too national." Yet Brooks's moderate tone masked "a smoldering hatred of abolitionists." 429

Of greater importance than his hatred of abolitionists was the fact that Brooks was the second cousin of Andrew Butler. Had he not been Butler's kinsmen, it is doubtful that Brooks would have done much more than complain about Sumner's speech, as most Southerners did. But the fact that Brooks was related to Butler gave an impetus to his hatred of abolitionists that, when combined with his "proud devotion to the South and to South Carolina", intense family loyalty, and "determination to live by the code of a gentleman" exploded in a shocking display of violence. $^{430}$

Brooks, along with several House colleagues, had been in the Senate Chamber on May 19 to when Sumner had given his speech. There was a lot of speculation concerning the speech and Brooks, like most Washingtonians, was curious as to what Sumner was going to say. Brooks's curiosity quickly turned to rage and he rushed out of the chamber after he heard Sumner refer to Butler as the 'Don Quixote of Slavery’. Brooks, perhaps sensing an inability to control his temper, did not attend the next day's session but instead chose to read newspaper accounts of the speech. Even those were enough to fill him with a terrible rage and on May 21, Brooks secured

\footnotetext{
${ }^{429}$ Before the encounter with Sumner, Brooks was perhaps best known for proposing that congressmen be required to check their firearms before entering the House Chamber Cong. Globe, Appendix, 876; Donald, Sumner, 289-90.

${ }^{430}$ Cong. Globe, Appendix, 876; Donald, $\underline{\text { Sumner, } 290 .}$
} 
a full printed edition of the speech. ${ }^{431}$ After reading the speech and finding it "as offensive as rumor had reported" and realizing that Butler was too old to deal with the powerfully built Sumner himself, Brooks decided to take action "to relieve Butler and to avenge the insult to my State." ${ }^{432}$

Among the parts of the speech that Brooks found offensive were the following passages in which Sumner, in language deliberately calculated to shock and outrage his audience, mocked the South's aristocratic pretensions:

The Senator from South Carolina (Butler) has read many books of chivalry, and believes himself a chivalrous knight with sentiments of honor and courage. Of course he has chosen a mistress to whom he has made his vows, and who, though ugly to others, is always lovely to him; though polluted in the sight of the world is chaste in his sight-I mean the harlot, slavery. For her his tongue is always profuse in words. Let her be impeached in character, or any proposition made to shut her out from the extension of her wantonness, and no extravagance of manner or hardihood of assertion is then to great for this senator. The phrenzy of Don Quixote in behalf of his wench Dulcinea del Toboso is all surpassed. ${ }^{433}$

Sumner's meaning could not have been clearer. While Butler and his fellow planters might claim to be paragons of virtue and pillars of Christian society they were, in their slavish devotion to barbarism (i.e. slavery), baser than the poor whites whom they so despised. Rather than bringing the blessings of Christianity to benighted African race, southerners were savage

${ }^{431}$ Cong. Globe, Appendix, 886; "Preston Brooks to J. H. Brooks," May 23, 1856, in Robert L. Meriwether (ed): "Preston S. Brooks on the Caning of Charles Sumner," South Carolina Historical and Genealogical Magazine, XII (1951), 2; Sumner Assault, pp. 61-2; "Statement by Preston S. Brooks," May 28, 1856, in Proceedings, (1927-8), 221; Donald, Sumner, 290; Nevins, 437.

${ }^{432}$ Cong. Globe, Appendix, 832 \& 886; Sydnor: "The Southerner and the Laws," 3-23; Williams: "The Code of Honor in Ante-Bellum South Carolina," 113-28; "Preston Brooks J. H. Brooks," May 23, 1856,, 2; $\underline{\text { Sumner }}$ Assault, pp. 61-2; "Statement by Preston S. Brooks," May 28, 1856, in Proceedings, (1927-8), 221; Donald, Sumner, 290-1.

${ }^{433}$ Donald, 295; McPherson, 122 \& 150; Sumner, “Crime,” 3. 
brutes who, like other semi-barbarians such as "the ancient Egyptians," "the Druids," "the Mexicans," "the Spaniards, who under Alva, sought to force the inquisition upon Holland," had by force subdued the weak and the defenseless: ${ }^{434}$ Now that they had so thoroughly established their dominance over those too helpless to resist, the southern chivalry now revealed its true character by threatening to break up the government if it did not assist them in perpetuating their exploitation and barbarism:

If the slave States cannot enjoy what in mockery of the great fathers of the Republic, he misnames equality under the Constitution-in other words, the full power in the national Territories to compel fellow men to unpaid toil, to separate husband and wife, and to sell little children at the auction block-then sir, the chivalric Senator will conduct the State of South Carolina out of the Union! Heroic knight! Exalted Senator! ${ }^{435}$

Brooks and his fellow southerners were outraged by the impudence of this Yankee who not only mocked them but their entire way of life. Even if the target of Sumner's words had been a complete stranger Brooks would have found them offensive, but the fact that they were directed at Butler, Brooks's kinsman, only added to the insult.

As a true southerner, Brooks was duty-bound to abide by the code of Southern honor which was very clear as to how such an insult should be answered. As Brooks said afterward: "I should have forfeited my own self-respect, and perhaps the good opinions of my countrymen if I had failed to resent such an injury by calling the offender in question to a personal account." Though the remarks were clearly slanderous, no self-respecting southerner would think to seek redress through the courts. That was for cowards and Yankees. The code of honor required that a true southerner answer such an insult personally, in other words through violent confrontation.

\footnotetext{
${ }^{434}$ Sumner, "Crime," 4.

${ }^{435}$ Sumner, "Crime,” 3-4.
} 
Among non-elite whites that usually meant fisticuffs. Among members of the planter class it usually meant the code-duello. ${ }^{436}$

In his youth, Brooks had fought a duel against Lewis T. Wigfall, but he never considered challenging Sumner to meet on the field of honor. First of all, believing as he did that "the moral tone of mind that would lead a man to become a Black Republican would make him incapable of courage," Brooks assumed, probably correctly, that Sumner would not accept the challenge. Secondly, since dueling was illegal in Washington D.C. he thought, again probably correctly, that Sumner would simply report the challenge to the police. Brooks believed that "the offence of 'sending a hostile message' added to the indictment for assault and battery would subject me to legal penalties more severe than would be imposed for a simple assault and battery." ${ }^{\text {437 }}$

But there was a more fundamental reason why Brooks did not challenge Sumner to a duel. According to the Southern code-duello, dueling was meant to be a means of settling disputes among gentlemen. To call Sumner to the field of honor would give him, in Southern eyes, a social respectability that Sumner, as a Yankee (and a Black Republican at that), did not merit. That left Brooks with one alternative: chastisement. As Brooks later explained: "To punish an insulting inferior, one used not a pistol or a sword but a cane or horsewhip." The whip

\footnotetext{
436"PRESTON S. BROOKS OF SOUTH CAROLINA ON THE SUMNER ASSAULT; HOUSE OF REPRESENTATIVES, JULY 14, 1856, Department of History, University of Virginia U.S. History Survey Course Website: Unit 4: Sectional Conflicts During the 1850s," http://www.iath. virginia.edu/seminar/unit4/brooks.htmal; Donald, Sumner, 290-291.

437"PRESTON S. BROOKS OF SOUTH CAROLINA ON THE SUMNER ASSAULT; HOUSE OF REPRESENTATIVES, JULY 14, 1856, Department of History, University of Virginia U.S. History Survey Course Website: Unit 4: Sectional Conflicts During the 1850s," http://www.iath. virginia.edu/seminar/unit4/brooks.html; "Preston S. Brooks, "Synopsis of Speech, on the $29^{\text {th }}$ of August, 1856, at Columbia, South Carolina." from the Political Text Book or Encyclopedia Containing Everything Necessary for the reference of the politicians and

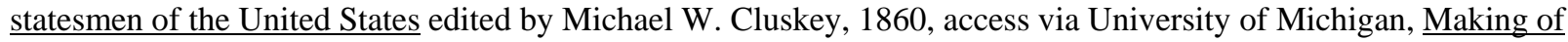
America website, (http://www.hti.umich.edu/cgi/text); Donald, Sumner, 290-291.
} 
Brooks rejected out of hand, fearing that Sumner might take it away and force Brooks "to do that which I would have regretted the balance of my natural life." Instead Brooks decided upon an eleven and one-half ounce, gold-headed, gutta-percha walking stick. ${ }^{438}$

Brooks was not the only person who was "looking" for Sumner. Southerners throughout the city were angrily discussing the speech. It was said that a South Carolinian "could not go into a parlor, or drawing-room, or to a dinner party, where he did not find an implied reproach that there was an unmanly submission to an insult to his State and his countrymen." ${ }^{439}$ Some of Sumner's friends, including Ohio Congressman John A. Bingham and Massachusetts senior Senator Henry Wilson, took notice of this menacing talk and urged Sumner to take precaution. Sumner, dismissing such threats as idle talk, refused to be intimidated and resisted all efforts to protect him. ${ }^{440}$

Idle talk or not, on the morning of May 21, 1856, Preston Brooks went to the Capitol grounds to carry out his mission of retribution. There he met up with Virginia Congressman Henry A. Edmundson, and Brooks told Edmundson of his plan to demand "an ample apology" for the remarks that Sumner had made. "It was time" Brooks said, "for southern men to stop this coarse abuse used by the Abolitionists against the southern people and States." Brooks felt that he would not be a proper representative of his State if he "permitted such things to be said."

\footnotetext{
${ }^{438}$ By this Brooks presumably meant that he might be provoked to kill Sumner. Cong. Globe, Appendix, 832; Sumner Assault, pp. 73, 75;"Preston S. Brooks, "Synopsis of Speech"; Sydnor: "The Southerner and the Laws,", 3-23; Williams: "The Code of Honor in Ante-Bellum South Carolina," 113-28; Donald, Sumner, 291.

${ }^{439}$ Cong. Globe, Appendix 632; Donald, Sumner, 289.

${ }^{440}$ Wilson, together with Representatives Anson Burlingame and Schuyler Colfax tried to accompany Sumner home after he had finished speaking on May 20 but Sumner who was unwilling to be "protected" slipped out a side door and walked home alone. Sumner Assault, 25, 42; Donald, Sumner, 289.
} 
When Edmundson asked how he could help Brooks replied that he did not wish Edmundson to take part in the attack but only to stand with him in case Sumner brought an escort. The two waited outside the Capitol until twelve-thirty but Sumner never showed up, which only made Brooks angrier. That evening Brooks met with two of his fellow South Carolina congressmen, Lawrence M. Keitt and James L. Orr, and told them of his plan. Keitt and Orr tried to talk him out of it, but Brooks would not be swayed. ${ }^{441}$

After a sleepless night, Brooks awoke early the next morning, May 22. In order to make sure that he did not miss Sumner a second time, Brooks arrived at the capitol at about eleven a.m. and positioned himself near the Capitol entrance. From there Brooks could easily intercept his quarry should Sumner follow his usual routine and walk to the capitol. On the other hand, if Sumner arrived by carriage, Brooks by simply cutting "through the grounds, up the flight of steps and through the Capitol" could intercept Sumner behind the building where the carriages stopped. While he waited, Brooks again met up with Edmundson who immediately saw a problem: If Sumner should arrive by carriage, Brooks would have to run up a long flight of stairs in order to catch him. In which case Brooks would be "too fatigued to deal with Sumner."442 Whether he accepted Edmundson's reasoning or he simply thought that Sumner had again eluded him, in either event, it being then twelve o'clock and time for Congress to convene, Brooks decided to go inside. Rather than follow Edmundson into the House, Brooks instead went to the Senate side where a eulogy was being read for recently deceased Missouri

\footnotetext{
${ }^{441}$ House Report, No. 182, $34^{\text {th }}$ Congress, First Session, 59; Proceedings, LXI, 2221-3; Donald, Sumner, 291.

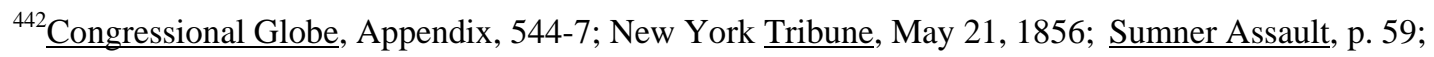

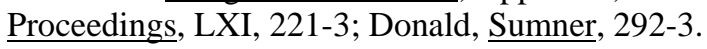


Congressman John G. Miller, in whose honor Congress adjourned at twelve forty-five. Brooks waited in the lobby for the chamber to empty. ${ }^{443}$

When the Senate adjourned, most of its members left immediately but a few lingered in both the chamber and the vestibule outside. Sumner remained at his desk franking copies of his speech for constituents. Brooks, meanwhile, had sat down at "a desk in the back row of the chamber, across the aisle and three seats away" from Sumner. There he waited impatiently for the room to empty. Brooks, by now livid with rage, could barely contain himself in the presence of a woman who was seated in the lobby only a few feet away. By now Brooks had been joined by Edmundson to whom Brooks complained bitterly that he could not approach Sumner while a lady was present. ${ }^{444}$ Brooks first tried to have the woman evicted by the sergeant-at-arms. When that failed he told Edmundson that "he would stand this thing no longer" and went out into the vestibule. There he scribbled out a note that demanded that Sumner "step outside." When Edmundson pointed out that Sumner would only send a note summoning him, Brooks decided to go back into the Senate chamber. ${ }^{445}$

While Edmundson stopped to chat with a colleague, Brooks continued into the Senate chamber where he found that the obstructing female had departed. Seeing his opportunity, Brooks did not hesitate and marched straight to Sumner's desk, while he still had the nerve.

\footnotetext{
${ }^{443}$ Congressional Globe, Appendix, 544-7; New York Tribune, May 21, 1856; Sumner Assault, pp. 23, 42, 60, 79; Donald, $\underline{\text { Sumner, 293-4. }}$

${ }^{444}$ When the House adjourned a few minutes before, Edmundson immediately came over to the Senate vestibule, where he met up with Keitt. When Edmundson suggested that the two of them should leave, Keitt refused saying: "No, I cannot leave till Brooks does" and went "behind the Vice-President's chair" to meet with a constituent. Proceedings, LXI, 221-3; Cong. Globe, 1, 292, Appendix, 544-7; Sumner Assault, pp. 23, 60, 63; Donald, Sumner, 293.

${ }^{445}$ Cong. Globe, Appendix, 544-7; Sumner Assault, pp. 42, 60, 79; Donald, Sumner, 294.
} 
What followed was the expressed rage, not only of Brooks himself, but of the entire South at what they considered the impudence of Northern mudsills and abolitionists. ${ }^{446}$ Brooks came right to the point: "Mr. Sumner....I have read your speech twice over carefully. It is a libel on South Carolina, and Mr. Butler, who is a relative of mine-" When Sumner tried to stand Brooks gave him "'a slight blow' with the smaller end of his cane." Sumner reflexively threw his arms out in self-defense, at which point Brooks seemed to lose control. He later wrote that he suddenly felt "compelled to strike him harder than (I) had intended." Caught off guard and pinned beneath his desk (which was bolted to the floor) Sumner struggled vainly to get to his feet with Brooks pummeling him all the while. ${ }^{447}$ Finally:

Eyes blinded with blood, "almost unconsciously, acting under the instinct of selfdefence," he then made a mighty effort to rise, and, with the pressure of his thighs, ripped the desk from the floor. Staggering forward, he now offered an even better target for Brooks, who, avoiding Sumner's outstretched arms, beat down "to the full extent of his power." 448

Brooks's blows were delivered with such force that his cane snapped in two. Sumner managed to stumble into the aisle where Brooks continued to beat him. Desperately trying to fend off blows, Sumner reeled "against the seats backwards and forwards," knocked over a desk, and nearly fell over. He was prevented by Brooks who had grabbed him by the lapel and

${ }^{446}$ William E. Gienapp, “The Caning of Charles Sumner and the Rise of the Republican Party,” Major Problems in the Civil War and Reconstruction Michael Perman, ed. (Boston: Houghton-Mifflin, 1998$) 43$.

${ }^{447}$ Sumner Assault, 26, 27-35, 57; Charles Sumner, "Testimony to House Select Committee" as quoted in "The Crime Against Kansas-Appendix-The Assault" Complete Works, 261; Proceedings, LXI, 222; Donald, Sumner, 294-6.

${ }^{448}$ Sumner Assault, 23-24, 32, 35, 56, 65, 79; Proceedings, LXI, 222; Donald, Sumner, 294-296. 
continued to deliver blows until the cane finally shattered in his hand. With that Brooks dropped the nearly unconscious Sumner to the floor. ${ }^{449}$

The incident lasted less than one minute. Brooks himself later summed up the attack in this way: "I . . gave him about 30 first rate stripes . . .Towards the last he bellowed like a calf. I wore my cane out completely but saved the Head which is gold." ${ }^{450}$ Nearly everyone in the vicinity of the Senate chamber had heard the sound of Brook's cane breaking over Sumter's head and they rushed to investigate. Among the first on the scene were Representatives Ambrose S. Murray and Edwin B. Morgan, who tried to break up the ruckus. While Murray tried to pull Brooks away, Morgan caught Sumner as he fell and prevented him from hitting the floor and thereby adding to his injuries. ${ }^{451}$ Close behind was Kentucky Senator John J. Crittenden who called out to Brooks in a loud voice: "Don't kill him.” Brooks, muttered his reply: "I did not intend to kill him, but I did intend to whip him." ${ }^{\text {452 }}$

Keitt, who had been standing near the clerk's desk, now came running up the center aisle waving a small cane above his head and yelling at Crittenden to "Let them alone, God damn you," while Toombs, of Georgia, warned Keitt not to strike Crittenden. ${ }^{453}$ Brooks, all this time,

\footnotetext{
${ }^{449}$ Cong. Globe, Appendix, 544-7; Charles Sumner, "Testimony to House Select Committee" as quoted in "The Crime Against Kansas-Appendix-The Assault" Complete Works, 261; James W. Simonton, Esq., Reporter of the New York Times, "Testimony before House Select Committee" as cited in "The Crime Against Kansas-

Appendix-The Assault”, Complete Works, 265; Donald, Sumner, 294-6; Sumner Assault, 27, 32, 37, 38, 40, 71, 80; "The Caning of Sumner, 2-3.

${ }^{450}$ Cong. Globe, Appendix, 544-7; Sumner Assault, 71 \& 80; Donald, Sumner, 294-6.

${ }^{451}$ Cong. Globe, Appendix, 544-7; James W. Simonton, Esq., Reporter of the New York Times, "Testimony before House Select Committee" as cited in "The Crime Against Kansas-Appendix-The Assault," Complete Works, 265; Sumner Assault, pp. 38-40, 48; Donald, Sumner, 295-6.

${ }^{452}$ Cong. Globe, Appendix, 544-7; Sumner Assault, pp. 30, 33, 49, 57; Donald, Sumner, 296.

${ }^{453}$ Cong. Globe, Appendix, 544-7; Sumner Assault, pp. 29, 58; Donald, $\underline{\text { Sumner, }} 296$.
} 
was struggling desperately to get away from Murray and continue the attack. After continuing to struggle for several seconds, Brooks was finally led into a side room where he had a small cut above his eye tended to. He then left with Keitt. Douglas had also heard the sound of the struggle and at first thought of trying to intervene but decided against it on the basis that "my relations to Mr. Sumner were such that if I came into the Hall, my motives would be misconstrued, perhaps."

Meanwhile, Sumner was still lying on the floor with "his feet in the aisle, and ... leaning partially against a chair." Representative Edwin B. Morgan, who along with Representative Ambrose S. Murray had come to Sumner's aid, described him as looking "senseless as a corpse.”455 After he regained consciousness, Sumner was given a glass of water by a page and, with the assistance of Morgan and Murray, was led into an anteroom. According to eyewitnesses Sumner's head was bleeding profusely and his clothes were soaked, almost from head to toe, with blood. A physician was summoned who tended to Sumner's wounds each of which required two stitches to close. ${ }^{456}$ Then Wilson, who upon hearing of the attack had rushed back to the Senate Chamber, took Sumner home and put him to bed. After a while the physician, Dr. Cornelius Boyle, came by to further check on Sumner's condition. After completing his examination, Boyle warned Wilson and the others that "it was absolutely necessary that he

\footnotetext{
${ }^{454}$ In retrospect, while the actions of Douglas and others in failing to come to Sumner's assistance seems somewhat cowardly, it should be remembered that Sumner was disliked by many of his Senate colleagues who, while they may not have felt that Sumner deserved the beating, were probably disinclined to risk injury to themselves by going to his aid. Cong. Globe, 1, 305; Sumner Assault, pp. 50, 71; Donald, Sumner, 296.

${ }^{455}$ Sumner Assault, 38-40; Cong. Globe, 1, 305; Donald, Sumner, 296-7.

${ }^{456}$ Sumner Assault, pp. 35-6, 41-2, 51; Cong. Globe, 1,305; Donald, $\underline{\text { Sumner, }} 297$.
} 
should be kept quiet, for he (Boyle) could not tell the extent of his injuries at that time."457 Before falling into a dazed sleep, Sumner was heard to remark that he could not believe that "a thing like this was possible." ${ }^{458}$

Reaction to Brooks's attack, like the reaction to the speech that had provoked it, was extreme and predictably sectional. Across the North news of the attack was received with mixed feelings of shock and outrage. Hundreds, perhaps thousands, of ordinary citizens wrote letters of sympathy and support for Sumter. One young correspondent, Mary Rosamond Dana, daughter of author Richard Henry Dana, expressed what was in many Northern hearts when she wrote: "Mr. Brooks is a very naughty man and if I had been there I would have torn his eyes out and so I would if I could." 459

Across the North cities, large and small, held huge public rallies to protest the assault and to demonstrate support for the man who was fast emerging as the martyr of the free soil movement. The largest of these rallies was probably the one held in front of New York's "Tabernacle" on May 30, 1856 where a vast crowd, described as being "made up of people who don't often attend political gatherings" heard many of the city's leading citizens speak "in terms and tones which would make Southern sneaks and bullies tremble in their shoes." A resolution condemning the attack was greeted with "Peal after peal, (and) cheer after cheer, ... like the

\footnotetext{
${ }^{457}$ Sumner Assault, p. 67; Donald, Sumner, 297.

${ }^{458}$ Donald, Sumner, 297.

${ }^{459}$ Donald, Sumner, 298-9.
} 
discharge of heavy artillery" while the name of Preston Brooks was met by "groaning and hissing." 460

The northern press dedicated a great deal of editorial space to the attack, condemning it in language deliberately tailored to offend the sensibilities of the planter elite, such as the following example from the New York Journal: "No meaner exhibition of Southern cowardice--generally miscalled Southern chivalry-was ever witnessed." ${ }^{461}$ Among the first to speak out was one of Sumner's hometown journals, the Boston Bee which in its May 23, 1856, editorial condemned Brooks as a disgrace to mankind, one who "ought to be branded as a villain of the blackest dye, and then mercilessly kicked from one end of the continent to the other." 462

At the same time, the Albany Evening Journal issued a call to northerners to be vigilant against Southern attempts to usurp federal power in defense of slavery. The Journal saw in the attack clear evidence that "the extreme discipline of the Plantation (has) been introduced into the Senate of the United States." ${ }^{463}$ Another New York paper, the Buffalo Morning Express went even further, and declared that no one should be surprised by Brooks's attack. To the contrary it was:

but the legitimate work of the spirit of slavery, which respects right nowhere. It is Missouri border ruffianism transferred to the Halls of Congress. It is a demoniac spirit

\footnotetext{
${ }^{460}$ Allan Nevins and Milton Halsey Thomas eds., The Diary of George Templeton Strong (New York: The Macmillan Co.; 1952), II, 276; Donald, $\underline{\text { Sumner, } 300 .}$

${ }^{461}$ (No Title), New York Tribune, 23 May, 1856, , from “Secession Era Editorials Project," Furman University History Department, Furman Online Primary Source Collection $\left(19^{\text {th }}\right.$ Century U.S. (http://history.furman.edu/`benson/docs (hereafter Furman), 1.

462“Attack on Mr. Sumner”, Boston Bee, 23 May, 1856, from Furman, 1.

463“The Ruffians in the Senate”, Albany (New York) Evening Journal, 23 May, 1856, from Furman, 1.
} 
which invades Kansas, Washington, here, and everywhere, and which, wherever it dares, depredating upon the rights of man. ${ }^{464}$

The Portland, Maine, Advertiser drew an even more direct link between "Bleeding Kansas" and "Bleeding Sumner":

The Minions of slavery and the Border Ruffians are doing their own work, both in Kansas and at Washington! The dastardly and perhaps murderous attack on Senator Sumner is on a par with their whole course. How long will the people of the Free States tamely submit to such outrages? ${ }^{465}$

In other words, the attack on Sumner had been neither an accident nor an isolated

incident. It was part of a larger pattern. The proslavery forces were embarked on a campaign to impose their will, through violent means, on the American body politic. Having failed to win the intellectual argument, they had resorted to physical force to literally beat into submission anyone who dared to oppose them: first on the plains of Kansas and now in the halls of Congress. But indeed, as the Advertiser itself so eloquently phrased the question: "How long will the people of the Free States tamely submit to such outrages?” 466

The Springfield Republican suggested a solution; arguing that: "The remedy for ruffianism resides in a united North. Old party names must be forgotten, old party ties surrendered. ${ }^{467}$ The Pittsburgh Gazette offered an even more extreme remedy, declaring that:

It is time, now, to inaugurate a change. It can no longer be permitted that all the blows shall come from one side. If Southern men will resort to the first blow to overawe and intimidate Northern men, blow must be given back for blow. Forbearance and kindly deportment are lost upon these Southern ruffians. It were as well to throw pearls before

\footnotetext{
464“"Ruffianism at Washington”, Buffalo (New York) Morning Express, 24 May, 1856, from Furman, 2.

465“The News”, Portland Advertiser, 23 May, 1856, from Furman, 1.

${ }^{466}$ Ibid.

${ }^{467}$ Donald, Sumner, 302.
} 
swine as turn one cheek to them when the other is smitten. Under the circumstances now prevailing, neither religion nor manhood requires submission to such outrages. Northern men must defend themselves; and if our present representatives will not fight, when attacked, let us find those who will.... The voters of the Free States, in vindication of their own manliness will hereafter, in addition to inquiring of candidates: Will you vote so-and-so, have to enlarge the basis of interrogation, and demand an affirmative answer to the question, Will you fight? ${ }^{468}$

Not everyone, however, was willing to see Sumner nominated for sainthood. ${ }^{469}$ For example, the Boston Courier in a lengthy editorial, declared that there could be "no palliation for the brutal assault which was made upon Mr. Sumner":

There is no chivalry in a brute. There is no manliness in a scoundrel. If Mr. Brooks is a nephew to Senator Butler, as it is said that he is, the Senator has only cause to regret that his blood runs through such ignoble veins. ${ }^{470}$

But at the same time, no one should overlook the fact that:

The speech of Mr. Sumner was exceedingly insulting towards some gentlemen who sit with him upon the Senate floor. It was not in consonance with the sort of arguments which people expect to hear from U.s.(sic) Senators upon a grave question. They do not want flowry(sic) adjectives or far-fetched allusions to, or illustrations from Greece and Rome, to give them an opinion as to how they shall act with regard to a practical question which is now before them. When Mr. Sumner compares Senator Butler of South Carolina and Senator Douglas of Illinois to Don Quixote and Sancho Panza, assimilating one to the character of a crazy man and the other to that of a fool, he takes a ground which Massachusetts, in her dignity and her ability, never presented before. ${ }^{41}$

The Democratic Cincinnati Daily Enquirer, in its May 23, 1856 edition, wrote that while

Brooks's actions were certainly not to be defended, neither should the American people allow themselves to be fooled by the efforts of abolitionists "to magnify Sumner into a martyr for

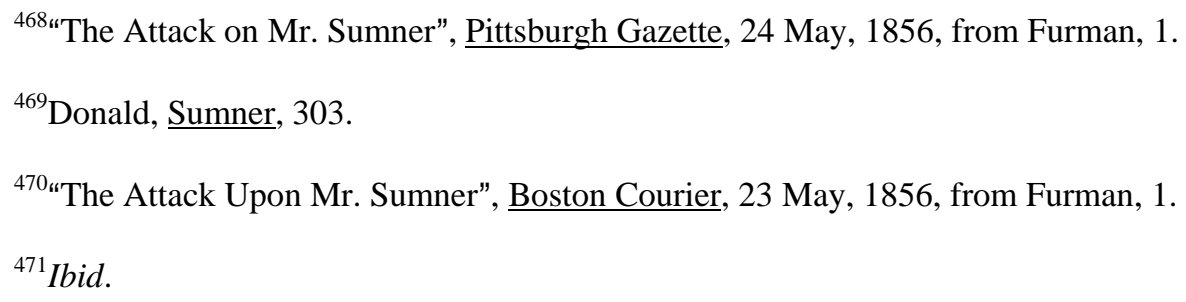


freedom and a victim of slavery." The paper added that "Whatever reprobation may be visited on Mr. Brooks . . . gentlemen everywhere will admit that Sumner's general tone was neither parliamentary nor gentlemanly." 472 The Montpelier Patriot and State Gazette, in a piece reprinted from the New Hampshire Democrat, was more blunt: "It is not slavery in Kansas which troubles them. (i.e. the Republicans) The spoils of office is what they are looking after."473

Indeed the political impact of the Brooks assault was enormous. It created, in Sumner, a political martyr for both the free-soil and Republican causes, a fact that the Republicans were quick to exploit. The fact that the attack took place at almost the same time as a raid on the freesoil strong-hold of Lawrence, Kansas, only enhanced its political value. Indeed the twin images of "Bleeding Sumner" and "Bleeding Kansas" gave the Republicans two powerful political weapons in the coming 1856 Presidential election. ${ }^{474}$ Some Republican politicos even went so far as to boldly predict that the affair would cost the Democrats the election. That didn't happen, but the fact that the Republican press distributed almost one million copies of the speech still attests to its value as political propaganda. ${ }^{475}$

Of course the impact of the attack was felt most keenly in Massachusetts where, at least initially, it seemed that the incident would have a unifying effect upon the notoriously partisan

472،Quid Pro Quo”, Cincinnati Daily Enquirer, 23 May, 1856, from Furman, 1.

473،True”, Montpelier (Vermont) Patriot and State Gazette, 13 June, 1856, from Furman, 1.

${ }^{474}$ Some political observers predicted that the "caning" might cost the Democratic party as many as 200,000

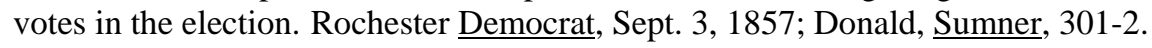

${ }^{475}$ While Fremont lost, the fact that a member of a fledgling party had finished second was quite impressive and boded ill for the Democrats in 1860. Ruhl Jacob Bartlett, "John C Fremont and the Republican Party" Ohio State University Studies: Contributions in History and Political Science, (Columbus: Ohio State University Press, 1930) No. 13, 61; Donald, Sumner, 301-2. 
Massachusetts political culture. A May 24, Faneuil Hall rally, featured speakers of nearly every political stripe, including some of Sumner's bitterest political foes like Democratic Governor Henry J. Gardner. ${ }^{476}$ Such unanimity was too good to last and it was not long before Sumner's enemies began to turn on their old nemesis. Daniel Webster's son, Fletcher, struck an especially sardonic note when he remarked that if Sumner planned to continue his Senate career he ought to "take the precaution of wearing an iron pot on his head." Others were even more rancorous in asserting that Sumner had gotten his just deserts: "I am happy that one man was found who chastised you, but ... you did not get one half what you merit.",477

These contrarian views notwithstanding, the public's reaction to the attack was overwhelmingly supportive of Sumner. According to Edward Everett the attack produced in Massachusetts "an excitement in the public mind deeper and more dangerous than I have ever witnessed ... If a leader daring and reckless enough had presented himself, he might have raised any number of men to march on Washington." ${ }^{478}$ More realistic was the assessment that the attack had helped Sumner's allies in the Massachusetts legislature to defeat an effort by Governor Gardner to weaken a personal liberty law that Sumner had helped to draft. Still many contemporary observers thought that the attack had revived a dying political career and might even make Sumner "senator for life." 479

\footnotetext{
${ }^{476}$ Donald, Sumner, 300-1.
}

${ }^{477}$ Charles T. Congdon: Reminisces of a Journalist (Boston: James R. Osgood and Company; 1880), p. 85; R. E. Apthorp to Sumner, May 29, 1856, Sumner MSS.; "A Pennsylvanian who is opposed to Slavery" to Sumner, May 25, 1856, Ibid. as cited in Donald, Sumner, 301.

\footnotetext{
${ }^{478}$ Everett to Horace Maynard, Oct. 23, 1857, copy, Everett MSS, as cited in Donald, Sumner, 300.

${ }^{479}$ Boston Advertiser, May 26-7, 1856; Donald, Sumner, 303-4.
} 
Reaction in the South was every bit as extreme and partisan as that in the North. In South Carolina public opinion seemed to solidify in designating Brooks, who before the attack had been a virtual unknown outside of his home district, as the hero of the hour. Just as Northerners rallied in support of Sumner, so too, did Southerners organize huge public rallies in support of their newly minted hero. ${ }^{480}$ The Columbia, South Carolinian, reported on one such rally held in Brooks's home district at Newberry, South Carolina, on May 24, 1856, at which:

Complimentary resolutions were introduced by Gen. A.C. Garlington, and ardent speeches made by him, Col. S. Fair, Maj. Henry Sumner, and others. The meeting voted him a handsome gold-headed cane, which we saw yesterday on its way to Washington, entrusted to the care of Hon. B. Simpson. At Anderson, the same evening, a meeting was called, and complimentary resolutions adopted. We heard one of Carolina's truest and most honored matrons from Mr. Brooks's district send a message to him by Maj. Simpson, saying "that the ladies of the South would send him hickory stick, with which to chastise Abolitionists and Red Republicans whenever he wanted them. ${ }^{481}$

Indeed, citizens and organizations throughout the South held similar rallies to raise funds to buy Brooks new canes to replace the one he had broken over Sumner's head. ${ }^{482}$

Opinion among the Southern press was also overwhelmingly favorable in fact the press's reaction to the assault was, if anything, even more extreme and more inflammatory than that of the public-at-large. ${ }^{483}$ The Greenville (S.C) Patriot and Mountaineer spoke for many southerners

${ }^{480}$ Donald, Sumner, 304-5.

${ }^{481}$ There were even reports that a group of slaves in South Carolina's capitol, Columbia, had collected money to buy Brooks a cane as "token of their regard" an act that the Charleston Mercury condemned as "a spectacle as disgusting as it is novel." "Public Approval of Mr. Brooks," Columbia (S.C.) South Carolinian, May 27, 1856, from Furman, 1; "A New Era," Charleston Mercury, May 29, 1856, from Furman, 1; also "The Caning of Sumner," p. 3; Schultz: Nationalism and Sectionalism, p. 119; Columbia South Carolinian, May 28, 1856; Richmond Enquirer, May 30, 1856; Donald, Sumner, 304-5.

${ }^{482}$ Soon after the attack Brooks told his brother that admirers were requesting pieces of the broken cane "as sacred relicts (sic)" Donald, Sumner, 304-5.

${ }^{483} \mathrm{~A}$ few of the South Carolina papers that endorsed Brooks's actions: Columbia South Carolinian;

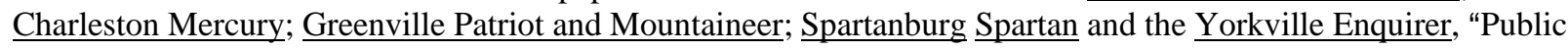


when it editorialized that Sumner had only gotten what he deserved: "We have no doubt that the Colonel did it handsomely, and we hope it will be of service to the Honorable Senator, in his future abolition frenzies. ...Well done for Col. BROOKS!" ${ }^{484}$ The Charleston Mercury went even further, declaring that not only the South supported Brooks, but "a large part of the North also., ${ }^{485}$

Most southern editorialists, however, were not as magnanimous toward their northern brethren seeing the attack as representing the first step toward "the solution of the great question of Southern rights. ${ }^{\text {"86 }}$ As the Laurensville (S.C.)Herald said in its account of the affair:

The first blow has been struck, which will be felt keener and longer than all the arguments and warnings ever used in Congress by Southern members, and, in our opinion, that blow is pregnant with results, which will be developed in hastening crisis to which we had before been more slowly approaching. Vituperative and libelous speaking in Congress has received a check which will weaken the arguments of our enemies more than anything else; and if the precedeent (sic) of Mr. Brooks be adopted by the whole Southern delegation, as their rule and course of conduct towards those who cannot, by courtesy and arguments of words, be made to respect and the people they represent, our opinion is, Congress will be freed from those unjust and unholy excitements which have of late years existed there, caused by the violent and mad ravings of those who prefer to pander to the prejudices of the masses than to allow reason, justice and dignity, to govern their acts and associations. ${ }^{487}$

Approval of Mr. Brooks," Columbia South Carolinian, May 27, 1856; (No Title) Charleston Mercury, May 28, 1856; "SUMNER CANED BY COL. BROOKS", Greenville Patriot and Mountaineer, May 29, 1856; "BROOKS AND SUMNER", Spartanburg Spartan May 29, 1856; "COL. BROOKS AND SUMNER”, Yorkville Enquirer, May 29, 1856, all from Furman; Donald, Sumner, 305-7. from Furman, 1.

484“SUMNER CANED BY COL. BROOKS", Greenville, (S.C.) Patriot and Mountaineer, May 29, 1856,

\footnotetext{
${ }^{485}$ (No Title) Charleston Mercury, May 28, 1856, from Furman, 2.

486“BROOKS AND SUMNER”, Spartanburg, (S.C.) Spartan May 29, 1856, from Furman, 2.

487،THE BROOKS MEETING”, Laurensville, (S.C.) Herald, June 6, 1856, from Furman, 1.
} 
Brooks's hometown newspaper, the Edgefield, South Carolina, Advertiser, put the matter more simply: "Hit him again."

Few Southern papers, and those mostly catering to border-state Whigs, criticized either Brooks or his attack. Only a very few, the Baltimore Maryland among them, were bold enough to actually condemn the assault or call for Brooks's expulsion from Congress. Most, like the Wilmington (N.C.) Herald) were content to merely criticize the specific circumstances under which it was carried out, noting that "The Senate Chamber is not the arena for exhibitions of this character . . . It is a shock to every man's sense of right and propriety." ${ }^{489}$ The Nashville, Republican Banner and Nashville Whig added that:

Mr. Brooks . . . could have sought and easily found Mr. Sumner elsewhere. His assault upon Mr. S., a member of the Senate, upon the floor of the Senate, was a great outrage upon that body, and cannot be justified or excused. The effect abroad of this occurrence can not fail to be deeply injurious to our national character. At home-in the non-slaveholding States-the effect will be to cause Mr. Sumner to be looked upon with increased consideration, and to strengthen the party to which he belongs. ${ }^{490}$

But by the same token, as the Raleigh Register pointed out, it should not be forgotten

what had provoked the attack in the first place:

The Senate chamber is, certainly, we admit, no place for brawls and fights, and every American citizen must lament the recent occurrence. But the Senate chamber, also, is no place for foul language, abuse, taunts, and opprobrious epithets. ${ }^{491}$

488“CAPT. BROOKS’ CASTIGATION OF SENATOR SUMNER”, Edgefield, (S.C.) Advertiser, May 28, 1856, from Furman, 1.

${ }^{489}$ Donald, Sumner, 305-6. Furman, 1.

490"'Messrs Sumner and Brooks," Nashville, Republican Banner and Nashville Whig, May 27, 1856, from

${ }^{491}$ (No Title) Raleigh Register, June 6, 1856, from Furman, 1. 
More to the point, as the Richmond Enquirer made clear, the true importance of the incident was not that it would build sympathy for Sumner, but rather that it demonstrated the inherent danger in allowing Sumner and other abolitionist "madmen" to their free speech "privileges" to "annoy and disturb society." According to the Enquirer there was but one solution:

The disgusting proceedings of their men, women and negroes, in their infidel, agrarian and licentious conventions, the destructive doctrines emanating from their press, and their lecture rooms, and the unfeminine bearing of their women, would justify and require an immediate and despotic censorship, it if were possible to take way their liberties without invading those of other people. ${ }^{492}$

With public opinion in such a state of arousal it was only natural that congressional debate would descend into an orgy of ad hominem attacks and personal recriminations. There were also a number of Congressmen, on both sides, who were by no means willing to restrict themselves to verbally attacking their enemies, but were prepared to follow Brooks's example and engage in actual physical confrontation. Brooks's accomplice, Keitt, noted that: "If the northern men had stood up, the city would now float with blood . . . Everybody here feels as if we were upon a volcano."493

Meanwhile, as the case was argued in the court of public opinion, the Brooks affair made its way through the legal system. Within days of the attack Brooks was arrested, charged with assault, and freed on $\$ 500$ bail. $^{494}$ Despite the efforts of some members, such as Massachusetts' senior Senator, Henry Wilson, to have the Senate condemn the assault, for a while it looked as

492“LIBERTY OF SPEECH, OF THE PRESS, AND FREEDOM OF RELIGION”, Richmond Enquirer, June 3, 1856; also "The Expulsion of Brooks," Richmond Whig, June 7, 1856, both from Furman, 1.

\footnotetext{
${ }^{493}$ Cong. Globe, 1,306, and Appendix, 631; “The Caning of Sumner,” p. 3; Donald, Sumner, 298 \& 307.

${ }^{494}$ Donald, Sumner, 297.
} 
though the Senate might take no action at all. Indeed opinion among Sumner's colleagues seemed divided as to whether Brooks should be censured or commended. ${ }^{495}$ After some not-sogentle prodding by Seward and others, an investigative committee was finally appointed.

Predictably enough the Committee, which did not include a single Republican member, reported that although the assault was a violation of Senate rules, since Brooks was not a member of the Senate, the attack did not lie "within the jurisdiction of the Senate, and can (sic) only be punished by the House of Reps." ${ }^{496}$

Having thus "passed the buck" to the House of Representatives, the Senate took no further action. The House meanwhile, despite threats from Southern fire-eaters to make the halls of Congress "ring with vollies (sic) from revolvers," had appointed an investigative committee of its own. The House Committee, which unlike its Senate counterpart had a Republican majority, conducted a rigorous investigation that interviewed a total of 27 witnesses, including Sumner himself. ${ }^{497}$ In its report, dated June 2, the committee recommended Brooks's expulsion and the censure of Edmundson and Keitt. The report sparked heated debate. The entire South Carolina delegation defended Brooks and Republicans rebutted their arguments. ${ }^{498}$

\footnotetext{
${ }^{495}$ When Wilson in his comments of May 23, 1856, denounced Brooks's attack as a "brutal, murderous, and cowardly assault." Butler, who had returned to Washington to defend Brooks, interrupted him by shouting: "You are a liar!" Two days later Brooks challenged Wilson to a duel, who refused on the grounds that dueling was "the lingering relic of a barbarous civilization, which the law of the country has branded as a crime." Cong. Globe, 1,306, and Appendix, 631; Donald, Sumner, 307.

${ }^{496}$ Cong. Globe, 1,279, 1,317; Donald, Sumner, 298.

497“The Caning of Sumner,” p. 3; Donald, Sumner, 298.

${ }^{498}$ Cong. Globe, Appendix, 656; Donald, Sumner, 308.
} 
The most vocal Northern respondent was Boston congressman, and Sumner's friend Anson Burlingame. On June 21, 1856, Burlingame accused Brooks of having sneaked up on Sumner and struck him down. Burlingame mocked Brooks in language deliberately calculated to appeal to, as Burlingame saw it, Southerners' delusions of gentility: "What! Strike a man when he is pinioned-when he cannot respond to a blow? Call you that chivalry? In what code of honor did you get your authority for that?" Brooks challenged him to a duel. Burlingame accepted, but when he selected the Canadian side of Niagara Falls as the location for the duel, Brooks backed out on the grounds that he dared not travel to Canada because he had received threats from New York and Philadelphia. This was a rather flimsy excuse and throughout the North Brooks was branded a coward and mocked with doggerel such as the following: "To Canada, Brooks was asked to go, To waste a pound of powder or so, But he quickly answered, ‘No, No, No, For I’m afraid, afraid, afraid,' Bully Brooks’s afraid."”99

After much debate, the motion to expel Brooks finally came to a vote on July 14, 1856, and gained a solid majority of 121 to 95 . But since a two-thirds majority was required, the motion to expel Brooks failed. The next day the House acquitted Edmundson and censured Keitt. Both Brooks and Keitt subsequently resigned their seats, returned to their home districts and won re-election. In the end the only penalty that Brooks ever had to pay was a \$300 fine imposed by the Baltimore district court. ${ }^{500}$

${ }^{499}$ Cong. Globe, Appendix, 656; Anson Burlingame as quote in "The Caning of Sumner-Appendix-Voice of the North," Complete Works, Vol. 5, 304; James E. Campbell: "Sumner-Brooks-Burlingame, or, The Last of the Great Challenges," Ohio Archeological and Historical Quarterly, XXXIV (1925), 435-73; The Liberator, XXVI (June 6, 1856), 91; Donald, Sumner, 311.

${ }^{500}$ Donald, $\underline{\text { Sumner, } 308 .}$ 
The "Caning of Sumner" was one of the most notorious incidents of the nineteenth century, one that inflamed passions in both North and South and played a critical role in bringing on the Civil War. Both Sumner's speech, and the attack that it provoked were carefully crafted pieces of political theater, each deliberately calculated to appeal to a specific audience: one northern, one southern; both steeped in antebellum notions of manhood which, while unique, also contained many similarities. The attack itself was both inspired by and symbolic of the violence then raging in "Bleeding Kansas" and also reflected the increasingly violent nature of sectional politics. It marked one of the earliest episodes in which a politician resorted to violence, rather than words, to defend his section's interests.

It bears repeating that the nature of the attack reveals much of how Northerners and Southerners viewed each other. The fact that Brooks chose not to challenge Sumner to a duel indicates that he did not consider Sumner, or any northerner for that matter, as his social equal. The code-duello, as practiced by members of the planter elite, carried the implicit understanding that it was meant to settle disputes among gentlemen. One did not challenge, nor accept challenges from, one's social inferiors. ${ }^{501}$

The "Caning" incident was also highly revealing of antebellum gender roles. Nothing so clearly illustrates this point, and Southern attitudes toward women in general, as the fact that Brooks waited until there were no women in the Senate Chamber before he carried out his attack on Sumner. ${ }^{502}$ "The Crime Against Kansas" speech also contains a wealth of information about

\footnotetext{
${ }^{501}$ Baldasar Castiglione, The Book of the Courtier ed. and trans. By George Bull (London: Penguin Books Ltd, 1967, 117-18; Bertram Wyatt-Brown, Southern Honor: Ethics and Behavior in the Old South (Oxford: Oxford University Press, 1982) 166-7.

${ }^{502}$ Donald, Sumner, 293-4.
} 
antebellum ideas of gender and sexual morality. It contains vivid, even crude, sexual imagery, makes idealized references to manhood and morality, and specifically attacks slavery for undermining those ideals. ${ }^{503}$

To those living in antebellum America Sumner's speech, with its overt sexual references, could only be interpreted as an attack upon Senator Butler's honor as well as that of the entire South. ${ }^{504}$ According to the code of southern honor such an attack demanded an aggressive answer. Senator Butler, old and infirm, could hardly be expected to confront Sumner himself. ${ }^{505}$ Brooks, as a steadfast devotee of Southern honor, felt it was his duty, as a man and a southerner, to "relieve Butler and avenge the insult to my State.".506

By the same token, Sumner felt it was his duty, as a northern man, to defend the free soil settlers in Kansas against Senator Butler and his pro-slavery hordes whose ultimate goal, in Sumner's view, was "the rape of a virgin territory." ${ }^{507}$ Thus it was their sense of duty, their sense of honor, their sense of manhood, that compelled both Sumner and Brooks to take action against what they considered to be public outrages. Obviously to the antebellum mind manhood was a

\footnotetext{
${ }^{503}$ Donald, 295; McPherson, 122 \& 150; Sumner, "Crime," 3.

${ }^{504}$ Preston Brooks to John Hamden Brooks, Washington, D.C. 23 May 1856, in "Preston S. Brooks on the Caning of Charles Sumner," Robert L. Meriwether, ed., South Carolina historical Magazine Vol. 52, No. 3, January 1951, 2; Nicole Etcheson, "Manliness and the Political Culture of the Old Northwest, 1790-1860", Journal of the Early Republic 15 (1975) 63; Bertram Wyatt-Brown, Southern Honor: Ethics and Behavior in the Old South (Oxford: Oxford University Press, 1982) 14, 34, 138; David Gilmore, Manhood in the Making: Cultural Concepts of Masculinity (New Haven, 1990), 12, 17, 110-16, 222-29.

${ }^{505}$ Ibid.

${ }^{506}$ Donald, 290; Preston Brooks to John Hamden Brooks, 2.

${ }^{507}$ Sumner, "Crime", 2.
} 
powerful motivator: powerful enough to lead both individuals and societies to violent confrontation. ${ }^{508}$

Reaction to the attack also split along sectional lines. In the South, Brooks's attack was regarded as neither extreme nor excessive but rather as a measured and restrained response to a personal insult. Preston Brooks had simply inflicted a caning, or a whipping, upon Sumner in order to chastise him for his unprovoked insults to Senator Butler and for his foul-mouthed denunciation of South Carolina. ${ }^{509}$ Brooks never lost control of himself a fact validated by statements Brooks made afterward in which he stated that: "Every lick went where I intended."510 After sufficiently warning Sumner, Brooks lightly struck him across the face. It was only after Sumner rose to defend himself that Brooks applied more force. Brooks himself later described the incident: "For about the first five or six licks he offered to make fight but I plied him so rapidly that he did not reach me. Towards the last he bellowed like a bull-calf"511 After that Sumner fell cringing to the floor, an inanimate lump of cowardice. It was a sign of Northern cowardice that though in Brooks's view he had suffered only from flesh wounds, Sumner fled the Senate due to wounded pride. Brooks, with conspicuous gallantry, promptly reappeared in the House of Representatives, ready to face all accusers. ${ }^{512}$

\footnotetext{
${ }^{508}$ Etcheson, 63; Wyatt-Brown, 14, 34, 138; Gilmore, 12, 17, 110-16, 222-29; Donald, Sumner, 290.

${ }^{509}$ Donald, Sumner, 309.

${ }^{510}$ Preston Brooks to John Hamden Brooks, 3.

${ }^{511}$ Preston Brooks to John Hamden Brooks, 2-3.

${ }^{512}$ Donald, 290; Preston Brooks to John Hamden Brooks, 3.
} 
Northerners, of course, had a different view. "Bully" Brooks had brutally, and without provocation, assaulted Sumner with a bludgeon. The alleged cause of the assault, Sumner's speech, was marked by the classic purity of its language and the nobility of its sentiments. The fearlessness of Sumner's ideas had, in fact, been what singled him out for assassination. Brooks was the mere tool of the slaveholding oligarchy. While fellow conspirators gathered around him to prevent interference, the South Carolinian stealthily approached Sumner and committed his brutal and barbarous outrage upon an unarmed man. Though Sumner courageously tried to defend himself, the ruffian took advantage of his defenseless position and of the surprise, beat Sumner senseless, and continued to strike him after he collapsed on the floor. ${ }^{513}$

Brooks was no hero, he was a bully and a coward who was too frightened to confront Sumner directly and on equal terms. Rather than being a valiant defender of Southern and family honor, Brooks had acted the coward, he caught Sumner off guard and trapped beneath his desk with little or no warning and little or no chance to defend himself from Brooks's blows. ${ }^{514}$ What kind of man, northerners asked with good reason, chose to defend his honor and that of his state by a sneak attack $?^{515}$

Brooks's protestations that he did not challenge Sumner to a duel because Sumner was his social inferior were a smoke screen to disguise the fact that he was too cowardly to meet Sumner on equal terms. The truth of this statement was to be found in the fact that Brooks had

${ }^{513}$ Donald, 310.

${ }^{514}$ Sumner Assault, 26, 27-35, 57; Charles Sumner, "Testimony to House Select Committee" as quoted in "The Crime Against Kansas-Appendix-The Assault" Complete Works, 261; Proceedings, LXI, 222; Donald, Sumner, 294-6

\footnotetext{
${ }^{515}$ Donald, 290; Preston Brooks to John Hamden Brooks, 2.
} 
not been too proud to challenge Anson Burlingame, another supposed social inferior (i.e.

Northerner) to a duel less than a month after the attack, presumably on the assumption that

Burlingame would refuse, and then had shown his true colors by backing down when

Burlingame actually accepted the challenge. ${ }^{516}$

Politically, the vote on Brooks's expulsion was equally ominous. While northerners were nearly unanimous in voting for expulsion, all but one Southern congressman voted against it. ${ }^{517}$ The Brooks expulsion resolution reflected a sectionalized pattern of voting that would intensify in the coming years. As can be seen, the same polarization had already appeared in newspaper opinion and in public and private reactions to the assault. To thoughtful observers, North as well as South, it was apparent that something dangerous was happening to the American Union. As Donald has written: ${ }^{518}$

When the two sections no longer spoke the same language, shared the same moral code, or obeyed the same law, when their representatives clashed in bloody conflict in the halls of Congress, thinking men North and South began to wonder how the Union could survive. $^{519}$

${ }^{516}$ Cong. Globe, Appendix, 656; Anson Burlingame as quote in "The Caning of Sumner-Appendix-Voice of the North," Complete Works, Vol. 5, 304; James E. Campbell: "Sumner-Brooks-Burlingame, or, The Last of the Great Challenges," Ohio Archeological and Historical Quarterly, XXXIV (1925), 435-73; The Liberator, XXVI (June 6, 1856), 91; Donald, Sumner, 311; Baldasar Castiglione, The Book of the Courtier ed. and trans. By George Bull (London: Penguin Books Ltd, 1967, 117-18; Bertram Wyatt-Brown, Southern Honor: Ethics and Behavior in the Old South (Oxford: Oxford University Press, 1982) 166-7..

${ }^{517}$ Cong. Globe, Appendix, 822; Donald, $\underline{\text { Sumner, }}$ 308-9.

${ }^{518}$ Donald, Sumner, 311.

${ }^{519}$ Donald, Sumner, 311. 


\section{CHAPTER 6}

\section{JEFFERSON DAVIS}

As an example of antebellum century American manhood, Jefferson Davis was very much a product of his time and of his environment. Growing up among the planter elite, Davis, like Preston Brooks, naturally absorbed "aristocratic" concepts of gentility and "chivalry." But at the same time, given the fact that Mississippi, in the early $19^{\text {th }}$ century was still very much a frontier society, Davis would have also been exposed to the same sort of 'rough-and-tumble' frontier masculinity that his presidential counterpart, Abraham Lincoln knew so well. But while 'frontier' masculinity undoubtedly helped to shape Davis's character, he would remain throughout his life a member of the planter class and it was with that class, and its ideals and values, including its concepts of masculinity, that Davis would most identify.

Born June 3, 1808, near Hopkinsville, Kentucky, Jefferson Finis Davis was the youngest of ten children born to Samuel Emory and Jane Cook Davis. ${ }^{520}$ In 1810 or 1811 Davis's family moved first to Bayou Teche, Louisiana, and then to Woodville, Mississippi Territory. ${ }^{521}$ By nineteenth-century standards Davis was fairly well educated, having first attended a log cabin

\footnotetext{
${ }^{520}$ Davis's siblings included Joseph (born: 1784); Benjamin (born 1787/88), Samuel (b. 1788/89), Anna Elizabeth (b. 1791), Isaac William (b. 1792), Lucinda (b. 1797), Amanda (b. 1799), Matilda (b. 1801) and Mary Ellen, nicknamed "Polly" (b. 1805) William C. Davis, Jefferson Davis: The Man and his hour, (New York: HarperCollins, 1991) (hereafter, Davis, Hour) 5-6.

${ }^{521 .}$ Soon after the family moved to Woodville, war broke out with the British and Jefferson's brothers Isaac and Samuel traveled to New Orleans to fight the British. Davis, Hour, 5-6, 11-13; Life and Reminiscences of Jefferson Davis by Distinguished men of his time, (Baltimore: R.H. Woodward \& Company, 1890) (hereafter Life) 3; William Allen Shelton, The Young Jefferson Davis, 1808-1846: A dissertation submitted in partial fulfillment of the requirements for the degree of Doctor of Philosophy at the University of Kentucky, (New York: Arno Press, 1982) 1, 2, 6-7; Clement Eaton, Jefferson Davis, (New York: The Free Press, 1977) 3-4; William J. Cooper, Jr., Jefferson Davis, American, (New York: Alfred A. Knopf, 2000) 9 \& 12; Felicity Allen, Jefferson Davis: Unconquerable Heart (Columbia: University of Missouri Press, 1999-Shade of Blue and Gray Series), 31, 35-7, 39, 40; Herman Hattaway and Richard E. Beringer, Jefferson Davis: Confederate President (Lawrence, Kansas: University Press of Kansas, 2002), 1.
} 
school near Woodville with his sister Polly in the fall of 1814. From 1816, until 1818, Davis

attended St. Thomas Academy, a Dominican boys' school located in Springfield, Kentucky.

Davis also briefly attended Jefferson College, Wilkinson County Academy, and Transylvania

University. In 1824, Davis won an appointment to West Point. ${ }^{522}$

After Davis graduated from West Point, in June, 1828, he served at a number of isolated

posts in Michigan and Wisconsin Territories and almost left the army but the outbreak of the

Black Hawk War in May, 1832, brought him back to active duty. ${ }^{523}$ After the Black Hawk War,

Davis was assigned as regimental adjutant to the newly formed First Dragoon regiment, stationed

at Jefferson Barracks and later transferred, in November, 1833, to Fort Gibson, in present-day

Oklahoma. ${ }^{524}$ A dispute with the Commanding Officer of the First Dragoons, led Davis to resign

his commission in March 1835. On June 17, 1835, Jefferson Davis married Sarah Knox Taylor,

\footnotetext{
${ }^{522}$ Abstract, "Register and Account Book, St. Thomas College," July 10, 1816, The Papers of Jefferson Davis, Haskell M. Monroe, James T. McIntosh, Lynda Lasswell Crist and Mary Seaton Dix, ed., 10 Vols. (Baton Rouge: Louisiana State University Press, 1971-1999) (hereafter D.P.) 3; Davis, Hour, 11-16; Life, 4; Jefferson Davis to Susannah Davis, August 2, 1824, Jefferson Davis, Private Letters, 1823-1889, Hudson Strode, ed. (New York: Harcourt, Brace, \& World, Inc., 1966) (hereafter D.L) 7; Abstract, "A Catalogue of the Officers and Students of Transylvania University,” July 1824, D.P., Vol. 1, 9; Cadet Jefferson Davis to John C. Calhoun, July 7, 1824, D.P., Vol. 1, 10; Jefferson Davis (hereafter J.D.) to Joseph Emory Davis, West Point, January 12, 1825, D.P., Vol. 1, 17; Davis, Hour 11-17, 20-25; Life, 4; Shelton, 10-11, 14, 15, 16-17, 18-25 passim, 29, 31, 32-39 passim, 47; Eaton, 45, 7, 13; Cooper, 15-17, 23-27, 28-29; Allen, 42-44, 45, 46, 48-49, 50-55, 56, 57-66; Hattaway and Beringer, 1-3, 11.

${ }^{523}$ Although he saw no fighting Davis took part in the capture of Black Hawk himself. P.B. Porter, Secretary of War, "Order: Promotions and Appointments," July 4, 1828, D.P., Vol. 1, 104; A.R. Jones, Adjutant General, "Abstract, Order No. 37," July 15, 1828, D.P., Vol. 1, 105; P.B. Porter, Secretary of War, "Abstract, Order: Promotions and Appointments, List," Adjutant General's Office, December 31, 1828, D.P. Vol. 1, 110; "Abstract, Post Return," Jefferson Barracks, March 31, 1829, D.P., Vol. 1, 116; “Abstract, Pay Voucher," Fort Winnebago,” May 31, 1829, D.P., Vol. 1, 117; R. Jones, Adjutant General, "Special Order No. 108,” July 21, 1832, D.P., Vol. 1, 249; Robert Anderson, Lt and Assistant, Inspector General, "Muster Roll Book," September 5, 1832, D.P., Vol. 1, 254-55; Life, 4-5; Davis, Hour 37, 39. 40-45; Shelton, 44-45, 46, 48, 53-55, 64; Eaton, 15-17, 21; Cooper, 40-47, 48, 53-53, 64-72; Allen, 66, 67-69. 71-75; Hattaway and Beringer, 3-4, 6.

${ }^{524}$ Lewis Cass, Secretary of War, to Second Lieutenant J.D., March 4, 1833, D.P. Vol. 1, 264; R. Jones, Adjutant General, "Order No. 14," March 6, 1833, D.P., Vol. 1, 265; "Field and Staff Muster Roll," August 31, 1833, D.P., Vol. 1, 286; Shelton, 80, 82; Cooper, 86, 112
} 
daughter of his former commanding officer and future president, Zachary Taylor. ${ }^{525}$ Following

Sarah's death, probably of malaria or yellow fever, Davis returned to the army in $1838 .^{526}$

Davis's political career began in February, 1843, when he and his brother Joseph were elected to the Mississippi State Democratic Convention at Jackson. Later that year he was nominated by the Democratic party for Congress but was defeated. ${ }^{527}$

In February, 1845, Davis married nineteen-year-old Varina Howell. ${ }^{528}$ The marriage was fruitful and Varina bore him six children: Samuel Emory Davis, born July 1852; Margaret Howell Davis, born February 1855; Jefferson Davis, Jr. born January, 1857; Joseph Evan Davis, born April, 1859; William Howell Davis born December, 1864 and finally Varina Anne ("Winnie") Davis born June 1864. ${ }^{529}$ Later in 1845, Davis ran again for Congress. This time he

525 “Marriage Register, Louisville, Kentucky," June 17, 1835, D.P., Vol. 1, 410, Life, 5; Shelton, 104-105, 107, 108, 127-129, 133; Eaton, 19 \& 22-25; Cooper, 68-72, 76-77, 97.

526 "Commission as First Lieutenant," May 10, 1834, D.P., Vol. 1, 321; "Proceedings of a General Court Martial, Trial of Jefferson Davis," February 12, 1835, D.P., Vol. 1, 357-381; Florida McCalab to J.D. October 15, 1837, D.L. 13; “Marriage Register, Louisville, Kentucky,” June 17, 1835, D.P., Vol. 1, 410; Davis, Hour, 56-58, 6266, 72, 74-75 \& 86; Life, 5; Shelton, 80, 82, 94-97, 104-105, 107, 108; Eaton, 18-19 \& 22-23; Cooper, 58-60, 6872, 76-77; Hattaway and Beringer, 5; Allen, 78-82.

527 "Abstract, Notice of the Proceedings of the Warren County Democratic Convention," December 17, 1842, D.P., Vol. 2, 15; "Abstract, Notice of the Proceedings of the State Democratic Convention," February 22-24, 1843, D.P., Vol. 2, 20-21; J.B. Williamson to 'Dear Sir' November 1, 1843, D.P., Vol. 2, 36; Shelton, 122, 123-126; Eaton, 47-48.

${ }^{528}$ Varina Banks Howell to Margaret K. Howell, December 19, 1844, D.P., Vol. 2, 52-53; J.D. to Varina Howell, November 22, 1844, D.L., 24-25; J.D. to Varina Howell, December 11, 1844, D.L., 25-26; J.D. to Varina Banks Howell, March 8, 1844, D.P., Vol. 2, 120-21 Davis, Hour, 62-63, 72, 74-75, 86, 90, 94-95, 107-108; Life, 5; Shelton, 104-105, 107, 108, 127-129, 133; Eaton, 19 \& 22-25; Cooper, 68-72, 76-77, 97.

${ }^{529}$ Remarkably, given the infant mortality rate at the time, all but two of the Davis children survived to adulthood. The eldest, Samuel Davis, died in June 1854, probably of measles. John Evan Davis died April 29, 1864, when he fell, head first, off the back balcony at the Confederate White House. V.D. to Margaret Howell, March 4, 1852, D.L., 65; V.D. to Margaret Howell, June 1852, D.L. 66; V.D. to J.D., August 20, 1852, D.L., 67; Dr. Robert C. Wood to Mrs. William B. Howell, January 24, 1857, D.L., 81; From William B. Howell to J.D., June 17, 1854, D.P., Vol. 5, 72-73; Davis, Hour, 115-120, passim, 219-220, 241, 255, 271-2; Eaton, 27, 79-80. . 
won easily and on December 8, 1845, took his seat in Congress. ${ }^{530}$ The following year, when the United States declared war on Mexico, Davis accepted command of the First Mississippi volunteers which formed part of General Zachary Taylor's northern army. ${ }^{531}$

In August, 1847, after his return from Mexico, Mississippi Governor Albert Brown appointed Davis to fill the vacancy created by the death of Senator Jesse Speight. ${ }^{532}$ Davis's first term in the Senate was highlighted by the controversy over Henry Clay's Compromise of 1850, in which Davis played a prominent role and in which he acted as "spokesman" for the South after John C. Calhoun was incapacitated due to poor health. ${ }^{533}$ In September 1851, Davis was asked to run for governor of Mississippi in place of his old Division Commander John A Quitman. A bout of fever confined him to bed for much of the campaign and Davis lost by a very narrow

530 "Extract, Notice of the Proceedings of the State Democratic Convention-Second Day," July 8, 1845, D.P. Vol. 2, 295-97; "State Wide Election Returns-Mississippi, November 3-4, 1845," D.P., Vol. 2, 357-359; "Extract, Notice of Arrival," House of Representatives, December 8, 1845, D.P., Vol. 2, 381; Davis, Hour, 118-23; Shelton, 134-137, 140-142; Eaton, 50-51, 55-56; Cooper, 117-120, 120-127.

${ }^{531}$ The First Mississippi was assigned to the Second Brigade, commanded by Brigadier General John A. Quitman; Third Division commanded by General William O. Butler; of Zachary Taylor's northern army of "invasion and occupation." General Zachary Taylor to J.D., August 3, 1846, D.L., 41; Extract, "Amendment to the Bill Authorizing the President to Accept the Services of Volunteers-Mexican War Bill," House of Representatives, May 11, 1846, D.P., Vol, 2, 582-82; Varina Davis (V.D.) to Margaret Howell, January 3, 1847, D.L. 45; J.D. to V.D., February 25, 1847, D.L., 47; J.D., "Speech at Natchez," June 14, 1847, D.P., Vol. 3, 183-84; Davis, Hour, 127-135, 137-9, 147, 149-150, 152; Life, 6-7; Shelton, 142, 183-84, 190, 192-93; Eaton, 62, 64-65; Cooper, 144-146, 150

${ }^{532}$ Davis was elected, in January, 1848, by the Mississippi legislature to fill the remainder of Speight's term. J.D. to V.D., May 27, 1847, D.L., 48; V.D. to Margaret Howell, Summer, 1847, 48-49; J.D. to Governor Albert G. Brown, August 15, 1847, D.P., Vol. 3, 207-208; V.D. to Margaret Howell, November 12, 1847, D.L., 545; Life, 13; Davis, Hour, 171-173, 178, 184; Eaton, 66-68; Cooper, 156-7, 159-64.

533 Jefferson Davis, The Rise and Fall of the Confederate Government, (New York: Thomas Yoseleff, 1958) 41; Eaton, 70; McPherson, Battle Cry, 70-71; "V.D. to Margaret Howell, April 1850, D.L., 60-61; V.D. to Margaret Howell, May 18, 1859, D.L., 61; J.D. "Amendment and Remarks on Purchasing Camels", November 22, 1850, D.P., Vol. 4, 167-170; J.D. "Remarks on Henry Clay's Resolutions”, January 29, 1850, D.P., Vol. 4, 62-70;

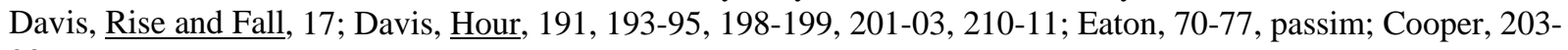
206. 
margin to Henry S. Foote. ${ }^{534}$ After losing the race for governor Davis, now out of work, retired temporarily to his plantation at "Brierfield." "535

In 1853, Davis joined the cabinet of his friend Franklin Pierce as Secretary of War. Among Davis's notable accomplishments as Secretary of War were increasing the size of the army and the pay for enlisted men; replacement of smoothbore muskets with modern rifles; strengthening of coastal defenses; construction of several new arsenals, armories and military roads, and increased training for state militias. ${ }^{536}$

After the Pierce Administration left office in March 1857, Davis was returned to the Senate and the chairmanship of the Senate Military Affairs Committee. ${ }^{537}$ In late Fall, 1859, Davis was appointed to a five man Senate Committee charged with investigating John Brown's

${ }^{534}$ Part of the reason for Davis's defeat may have been the persistent rumor that he was dead. J.D. to David L. Yulee, July 18, 1851, D.P., Vol. 4, 218; Ethelbert Barksdale to J.D., September 19, 1851, D.P., Vol. 4, 222-23; V.D. to William Burr Howell and Margaret Howell, October 25, 1851, D.L., 63-64; J.D. "Speech at Athens, Mississippi", October 27, 1851, D.P., Vol. 4, 231-232; Reuben Davis to J.D., November 1851, D.P. Vol. 4, 232-33; V.D. to William Burr Howell and Margaret Howell, October 25, 1851, D.L., 63-64; Ethelbert Barksdale to J.D., September 19, 1851, D.P., Vol. 4, 222-23; J.D. "Speech at Athens, Mississippi", October 27, 1851, D.P., Vol. 4, 231-21; Reuben Davis to J.D., November 1851, D.P. Vol. 4, 232-33; J.D. to William R. Cannon, Washington D.C., December 13, 1858, D.P., Vol. 5, 52-53.; Rise and Fall, 19-20; Davis, Hour, 211-212, 213-216, 217; Eaton, 78-79; Cooper, 209-215, 219-222; Freehling, 526-28.

${ }^{535}$ Davis, Hour, 219-220, 241, 255, 271-2; Eaton, 27, 79-80.

${ }^{536}$ Davis also had some notable failures as War Secretary, the most notable of which was his absurd idea of utilizing camels in the deserts of the Southwest an idea that had been laughed out of congress years before. A.G. Brown to J.D., January 1, 1853, D.P., Vol. 5, 3-4; J.D. to John E. Wool, April 14, 1854, D.P., Vol. 5, 63-64; J.D., Secretary of War, to John J. Abert, Chief of the Bureau of Topographical Affairs, U.S. Army, June, 16, 1853, D.P, Vol. 5, 21; J.D. to Persifer F. Smith, June 19, 1854, D.P., Vol. 5, 73-74; J.D., Secretary of War, "Speech at Washington at groundbreaking ceremonies for aqueduct project," November 8, 1853, Vol. 5, 48=49; J.D. Secretary of War to Montgomery C. Meigs, U.S. Army Corps of Engineers, June 3, 1853, D.P., vol. 5, 18-19; J.D., Secretary of War to Antoine Etex, August 10, 1855, Vol. 5, 116; Davis, Rise and Fall, 23-24; Davis, Hour, 226-227, 232-35, 237, 243; Morris Schaff, Jefferson Davis: His Life and Personality (Boston: John W. Luce and Company, 1922) 7778, 79-82; Life, 31-34; Eaton, 82-84, 85-86, Hattaway and Beringer, 11-12.

${ }^{537}$ V.D. to William Burr Howell, February 13, 1857, D.L., 83; J.D. to President James Buchanan, June 19, 1857, D.L., Davis, Rise and Fall, 25; Schaff, 84, 89, 93; Eaton, 93; Life, 18. 
October 16, 1859, raid on Harper's Ferry. In its final report the committee concluded that the raid "was simply the act of lawless ruffians, under the sanction of no public or political authority." ${ }^{538}$

The election campaign of 1860 found Davis, once again, at the center of national political events. Davis realized that the Democratic party's split into two factions at the Charleston Convention, rendered them easy pickings for Lincoln and the Republicans. With that in mind Davis tried to broker a compromise between the Northern Democrat candidate, Stephen Douglas, and the Southern Democrat candidate John Breckinridge. Since Davis regarded Breckinridge as the only candidate capable of beating Lincoln, he proposed that Douglas withdraw from the race and throw his support behind Breckinridge. Despite Davis's best efforts, Douglas refused to withdraw. ${ }^{539}$ In November, just as Davis feared, Lincoln was elected. ${ }^{540}$

On the same day that South Carolina seceded, December 20, 1860, Davis was appointed to the thirteen member Joint Congressional Committee which was charged with finding a compromise solution to the crisis. In the end their efforts came to nothing and after Mississippi seceded, on January 9, 1861, Davis resigned his Senate seat. ${ }^{541}$ On February 4, representatives of the seceded states gathered at Montgomery, Alabama, where they formed a new government,

${ }^{538}$ Amos A. Laurence to J.D., December 22, 1855, D.P., Vol. 6, 267-68; Richard Brodhead to J.D., December 24, 1859; D.P., Vol. 6, 269-70; Davis, Hour, 274, 276 \& 277; Schaff, 100-102.

539 J.D., Address to the National Democracy, May 7, 1860; D.P., Vol. 6, 289-93; J.D., Reply to Stephen A.

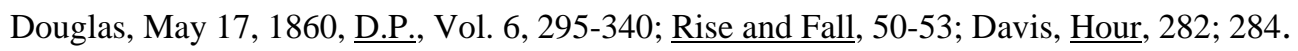

${ }^{540}$ J.D. to Robert Barnwell Rhett, Jr., November 10, 1860, D.P., Vol. 6, 368-70; V.D. to J.D., November 15, 1860, D.P., Vol. 6, 371-72; Rise and Fall, 52-53.

${ }^{541}$ Rise and Fall, 52-53, 60-61; Life, 34. 
the Confederate States of America. On February 8, the delegates elected Jefferson Davis as the first (and as it turned out, the last) President of the Confederate States of America. ${ }^{542}$

In discussing the life of Jefferson Davis: his character, his attitudes, his values, and even his ideas of masculinity, one must first take note of the importance of Davis's relationship with his brother Joseph. As the youngest of ten children, Jefferson Davis probably had a somewhat distant relationship with his father. In fact Samuel Davis was of such "advanced" age (he was well past fifty when Jefferson was born) that Jefferson probably regarded him more as a grandfather than as a father. ${ }^{543}$ As a result, Jefferson Davis probably looked more to his older brothers as his model of manhood, especially Joseph who, when Samuel died in 1824, assumed the role of family patriarch. ${ }^{544}$ Joseph Davis became not only a surrogate father to Jefferson but the most influential person in his life, deliberately molding Jefferson in his own image. As he did so, and as Jefferson Davis came more and more to emulate his brother, Joseph's opinions became Jefferson's opinions, Joseph's politics became Jefferson’s politics; Joseph's attitudes toward slaves became Jefferson's attitudes toward slaves. Most importantly Joseph's ideas of manhood became Jefferson's ideas of manhood. ${ }^{545}$

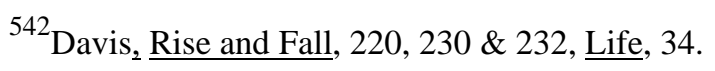

${ }^{543}$ J.D. to Susannah Gartley Davis, August 2, 1824, D.P 1: 11; Davis, $\underline{\text { Hour, }} 24$.

${ }^{544}$ Ibid.

${ }^{545}$ Samuel Davis to J.D., June 25, 1823, D.P., 1: 4-8; J.D. to Susannah Gartley Davis, August 2, 1824, D.P,
} 1: 11; Davis, $\underline{\text { Hour, 94-5. 110. } 166 .}$ 
This displacement of Samuel as Jefferson Davis's father-figure began before Samuel's death and persisted into adulthood and had a profound effect on Jefferson Davis's development as a man. Joseph Davis possessed many qualities that made him a admirable role-model: he was a devoted family man, successful attorney, leader of the Mississippi Democratic party, and while he was a slave owner, his views on slavery and slave management were considered very enlightened for the time. But, in a society, such as antebellum South, in which notions of patriarchal authority were accorded such importance, by deliberating molding Jefferson in his image and so completely supplanting Samuel as Jefferson's model of manhood, Joseph may have created confusion within the young man regarding the nature of fatherhood and about male gender roles in general. ${ }^{546}$ Joseph's overwhelming, one might almost say oppressive, influence may also have created within Jefferson an inordinate need for the acceptance and approval of men and, worst of all, may have retarded the development of Jefferson's own sense of identity. Even as an adult, Jefferson Davis did not always seem to be able to think for himself and he usually deferred to Joseph's judgements and opinions. ${ }^{547}$

But his brother Joseph was not the only southern male who influenced Jefferson Davis. To begin with, Davis would have certainly absorbed notions of masculinity from his other brothers and from friends and neighbors. But perhaps of greater importance was the fact that

\footnotetext{
546 "Abstract, Notice of the Proceedings of the Warren County Democratic Convention," December 17, 1842, D.P., Vol. 2, 15; "Abstract, Notice of the Proceedings of the State Democratic Convention," February 22-24, 1843, D.P., Vol. 2, 20-21; J.B. Williamson to 'Dear Sir', November 1, 1843, D.P., Vol. 2, 36; Davis, Hour, 78, 90, 94-5; Shelton, 122, 123-126; Eaton, 47-48; Freehling, 498.

${ }^{547}$ A good example of this occurred in 1832 when Davis considered leaving the army to pursue an opportunity with a railroad being constructed in Mississippi but was talked out of it by Joseph who considered it too risky. Rather than take the risk, and pursue the opportunity, Jefferson automatically deferred to Joseph's opinion. J.D. to Joseph Emory Davis, West Point, January 12, 1825, D.P., Vol. 1, 17; .Davis, Hour 11-17, 20-26, 48-49; Life, 4; Shelton, 18-25 passim, 29, 31, 32-39 passim, 47; Eaton, 5, 7, 13; Cooper, 23-27, 28-29; Allen, 50-55, 56, 57.
} 
Davis was also fortunate enough to have met the two men who, at the time, were most closely associated in the public mind with southern manhood: Andrew Jackson, whom Davis met in 1816 while on his way to St. Thomas Academy in Kentucky and John C. Calhoun, whom Davis met in 1845, shortly after his election to Congress. ${ }^{548}$

Certainly Calhoun and Jackson had much to recommend them as models of southern manhood. Both embodied, to a considerable degree, many of the characteristics that antebellum southerners (and northerners for that matter) associated with masculinity. Of the two, Calhoun was more the "true aristocrat." ${ }^{\text {449 }}$ Although his actions in the Nullification Crisis fell far short of the masculine virtue of candor, Calhoun was every inch the $19^{\text {th }}$ century gentlemen. He was well educated, dignified, studious, intellectual, and uncompromising to the point of being selfrighteous and narrow in his thinking. ${ }^{550}$

While he agreed with Jackson about the inherent superiority of whites over Blacks and Indians, Calhoun was suspicious of the democratic forces that Jackson had unleashed ("King Numbers" as Calhoun called them) and believed that aristocrats should not only control blacks but that "the best men must govern all races." As a typical Carolinian elitist, Calhoun, unlike Jackson, did not believe 'the people' capable of governing themselves. On the contrary Calhoun felt that "independent gentlemen must impose civil virtue from above." ${ }^{551}$ Calhoun never fought a duel nor went to war, but he displayed great courage during the Senate debates over the

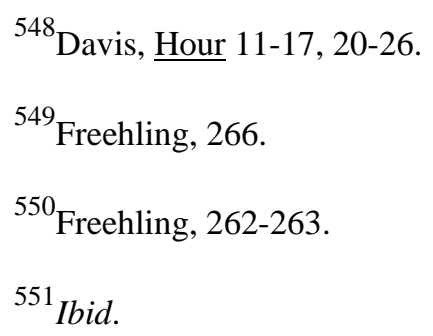


Compromise of 1850. Although too sickly to speak himself, Calhoun sat stoically in the Senate chamber while a colleague read his response to Clay's compromise proposals. Calhoun's pride, dedication, and sense of duty in insisting that he attend, despite being literally on the verge of death, spoke volumes about the nature of southern manhood. ${ }^{552}$

Andrew Jackson, on the other hand, while he was also a member of the planter class strongly believed in the concept of herrenvolk democracy-the idea that all white males were innately equal and innately superior to blacks and Indians. ${ }^{553}$ But, as evidenced by his war against Nicholas Biddle and the Bank of the United States, Jackson had a natural distrust of "presumptuous elites (who) spread civic vice." "554

More to the point, in reference to his espousal of antebellum masculinity, Jackson was known far-and-wide as a fierce warrior who, in his numerous engagements against Indians and the British, displayed great courage while under fire. In fact Jackson had risen to national prominence largely on his reputation as a war hero. Like most American males at the time Jackson placed a high value on honor. Indeed he was the only president known to have killed a man in a duel--and that over the honor of a lady. Likewise Jackson was a man known for his candor and for being utterly unafraid to speak his mind. Finally, in his handling of the Nullification Crisis Jackson had shown a resolute strength of will and a degree of political courage rarely seen in American politics before or since. ${ }^{555}$

\footnotetext{
${ }^{552}$ Freehling, 266.

${ }^{553}$ Ibid, 262, 450.

${ }^{554}$ Ibid, 263, 266, 269.

${ }^{555}$ Ibid, 268.
} 
Despite the fact that Davis met these two great southerners at different stages in his life, he met Jackson as a schoolboy and met Calhoun as an adult, both men profoundly influenced Davis's life, character, and his conceptions of masculinity. Davis came to idolize both Jackson and Calhoun and emulated different aspects of their individual characters. From Jackson Davis derived the importance of honor and personal reputation, moral rectitude, courage and military valor. From Calhoun, Davis derived the importance of social refinement, intellectual achievement, skill in parliamentary debate, dedication to the defense of southern 'rights' and southern 'civilization.' From both men Davis learned to be unyielding, resolute, and steadfast in defense of his principles. Davis, unfortunately, carried this trait to a greater extreme than even Jackson or Calhoun ever imagined. Davis has often been described, by scholars and contemporaries alike, as unbending, stubborn, even dogmatic. ${ }^{556}$

Together, then, these three men, Andrew Jackson, John C. Calhoun and Joseph Davis, molded Jefferson Davis's character and his image of manhood to a greater degree than everyone else combined. ${ }^{557}$ But of the three, Joseph was the dominant influence. In fact so strong was Joseph's influence over Jefferson that it even carried over into married life. As the eldest brother and family patriarch, Joseph felt it was his responsibility and his right to indoctrinate any prospective bride as to the expectations of a Davis wife. Davis's first union, with Sarah Knox Taylor, was so brief (she died only three months into the marriage) that it is difficult to gain a

${ }^{556}$ Extract, Jefferson Davis, Jefferson Davis, Ex-President of the Confederate States of America: A Memoir in D.P., Vol. 1, lxx-lxxi.

${ }^{557}$ Davis was chosen to accompany Calhoun's body home after his death in 1850. V.D. to Margaret Howell, April 1850, D.L., 60-61; V.D. to Margaret Howell, May 18, 1859, D.L., 61; Davis, 193, 198-9; Eaton, 71-2. 
sense of the social pattern within the marriage. ${ }^{558}$ However, Davis's second marriage was a

different matter. ${ }^{559}$ Varina Howell Davis was a high spirited young woman (she was only nineteen when she married thirty-seven year old Jefferson Davis) with a mind of her own who had no intention of deferring to the wishes of her husband, or to those of his brother. ${ }^{560}$

In fact Varina Davis often failed to conform to what was considered the proper role of a woman (especially a married woman) in antebellum America. It is important to point out that, judged by modern standards Varina Davis did nothing that could be even remotely construed as improper. But such was the nature of antebellum gender roles, and such was her husband's attachment to the maintenance of those gender roles, that conflict was inevitable. This was especially true in the early years of the marriage when Varina was very vocal in expressing her feelings and opinions. Varina's outspokenness was not at all in keeping with her husband's idea of proper female conduct and this resulted in many bitter arguments between the two. On at least one occasion the argument became so bitter that Varina actually left Davis and went to stay with friends in New Hampshire. ${ }^{561}$

${ }^{558}$ Florida McCalab to J.D., October 15, 1837, D.L. 13; Davis, Hour 72, 74-75 \& 86; Life, 5; Shelton, $104-$ 105, 107, 108; Eaton, 19 \& 22-23; Cooper, 68-72, 76-77.

${ }^{559}$ Varina Banks Howell to Margaret K. Howell, December 19, 1844, D.P., Vol. 2, 52-53; J.D. to Varina Howell, November 22, 1844, D.L., 24-25; J.D. to Varina Howell, December 11, 1844, D.L., 25-26; J.D. to Varina Banks Howell, March 8, 1844, D.P., Vol. 2, 120-21; J.D. to Varina Banks Howell, March 15, 1844, D.P., Vol. 2, 127-128; J.D. to Varina Banks Howell, June 22, 1844, D.P., Vol. 2, 172-73; "Certificate of Marriage, Adams County, Mississippi," February 26, 1845, D.P. Vol. 2, 237; Davis, Hour, 90, 94-95; Shelton, 128-129, 133; Eaton, 23-25; Cooper, 97.

${ }^{560}$ Varina Banks Howell to Margaret K. Howell, December 19, 1844, D.P., Vol. 2, 52-53; J.D. to Varina Howell, November 22, 1844, D.L., 24-25; J.D. to Varina Howell, December 11, 1844, D.L., 25-26; J.D. to Varina Banks Howell, March 8, 1844, D.P., Vol. 2, 120-21 Davis, Hour, 62-63, 72, 74-75, 86, 90, 94-95, 107-108; Life, 5; Shelton, 104-105, 107, 108, 127-129, 133; Eaton, 19 \& 22-25; Cooper, 68-72, 76-77, 97.

${ }^{561}$ The specific incident in question took place in 1846 and began when Varina objected, quite strongly, to Jefferson's decision to volunteer for service in Mexico. This was only a few months after another bitter fight that 
It seems clear however, from the available evidence, that the main source of tension within the Davis marriage was Jefferson's brother Joseph. Simply stated Joseph and Varina could not stand each other. The two clashed almost from day one, in fact they even fought over the wedding plans. In part this was to be expected, Joseph Davis was in his fifties and so it was perhaps only natural that he should see Varina as a child who needed the 'guidance' of an older male. That, combined with Joseph Davis's patriarchal attitudes which led him to view women as subordinate to men could not help but cause trouble, especially since as a male role model Joseph's attitudes tended to rub off on Jefferson. ${ }^{562}$

This fact became abundantly clear to Jefferson Davis when he came home on leave from Mexican War and found himself caught in the middle of a furious row between Joseph and Varina. Ostensibly the source of the argument was a difference of opinion regarding renovations to the main house at Brierfield, but the real cause was probably Joseph's belief that Varina needed to be put in her place. Not surprisingly, Jefferson Davis agreed with his brother on this point and he frequently complained, to anyone who would listen, that Varina was not 'demure' enough. ${ }^{563}$

By the time Davis returned from Mexico for good, in Fall 1846, the fight had grown so bitter that Davis described Varina's demeanor as "open rebellion." It must have seemed so because when Jefferson left for Washington to take his seat in Congress he left Varina behind at 134-137, 142, 183-84, 190, 192-93; Eaton, 50-51. 57-59; Cooper, 119-26, 129.

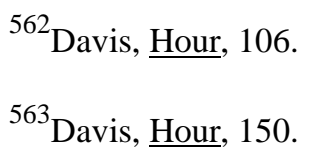


Brierfield. The following spring (of 1847) when Davis returned to Brierfield he did so with the intention, as he phrased it, to "put his house in order." Whether Davis was entirely successful in this is not entirely clear, but it bears noting that soon after Davis returned from Washington Varina began reading domestic tracts such as The Guide to Social Happiness. ${ }^{564}$ This may have been a desperate attempt to save her marriage. If so it was a successful one because by July 1849 when Jefferson Davis, by then a Senator, returned home for health reasons a marked change had taken place. Jefferson now found himself at odds with Joseph. The exact cause of the falling out is unclear but it seems safe to assume that it had something to do with Varina. Whatever its cause the disagreement was serious enough to lead Jefferson to consider selling Brierfield and moving away. Eventually the quarrel between the brothers was patched up, but the ill-feeling between Joseph and Varina persisted for years. ${ }^{565}$ In 1859 when Jefferson decided to name their second child Joseph Evan Davis, after his brother, Varina was almost inconsolable. ${ }^{566}$

Aside from his emulation of his brother Joseph, Jefferson Davis possessed many of the qualities that nineteenth-century Americans often associated with masculinity. Davis, like Lincoln, was hardworking and possessed a very strong sense of duty. Even Davis's harshest critics conceded his strong sense of dedication. During his first term in Congress Davis was so preoccupied with tending to his duties that he nearly worked himself to the point of exhaustion. As William C. Davis put it in his biography Jefferson Davis: The Man and His Hour, Davis

\footnotetext{
${ }^{564}$ J.D. to V.D. August 16, 1846, D.P, 1: 16; J.D. to V.D. December 10, 1846, D.P., 1:16; Davis, $\underline{\text { Hour, }} 218$.

${ }^{565}$ Davis, Hour, 220, 271-2.

${ }^{566}$ It is worth noting that as the family patriarch naming the children was Jefferson's prerogative. Varina had almost no say in the decision. Davis, Hour, 220, 271-2.
} 
"buried himself in the minutiae of his job; making little or no distinction between matters great or small." This level of dedication, this preoccupation with matters both trivial and profound, became a lifelong habit for Davis and marked his long record of public service. ${ }^{567}$

In February 1858, during his service in the U.S. Senate, Davis came down with a severe cold that eventually advanced into an advanced case of laryngitis that left him bedridden for weeks and nearly killed him. But in April 1858, when the "English Compromise" came up for a vote Davis insisted on being carried to the Senate Chamber, only to learn that the vote was postponed until the next day. This level of dedication continued even after secession. Unlike many southern senators and representatives who took it upon themselves to decide when to withdraw from Congress, Davis remained at his post until he received specific instructions from Mississippi's governor to resign his seat. ${ }^{568}$

Like most southerners of the planter class, Davis's views on race in general and slavery in particular were strongly influenced by, and in turn influenced, his views on manhood. And of course his views on race and slavery, like his views on nearly everything else, were largely inherited from his brother Joseph. Joseph and Jefferson Davis had ideas of slave management that were considered enlightened for the time. Despite the claims of slavery apologists that most slaves were content with their lot, in reality maintaining control and discipline were the most

${ }^{567}$ Varina Davis to Margaret Howell, January 30, 1846, D.L., 35-36; "Extract, Notice of Arrival," House of Representatives, December 8, 1845, D.P., Vol. 2, 381; Davis, Hour, 115-20; Shelton, 140, 141, 142; Eaton, 53-55; Cooper, 117-20.

${ }^{568}$ Alexander Davis Bache to J.D., July 2, 1858, D.L., 98; V.D. to Margaret Howell, September 15, 1858,

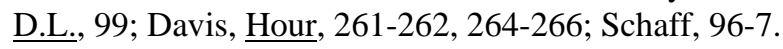


difficult problems that any slaveowner faced. ${ }^{569}$ Unlike most masters who maintained control through severe, even violent, means such as stocks, shackles, thumbscrews, and the lash, the Davises took a different approach. ${ }^{570}$

The Davises based their system of slave management on the ideas of industrial reformer Robert Owen. From Owen, Joseph acquired the notion that "humanity and generosity bred character and loyalty." Sounding more like a northern capitalist than a southern slaveowner, Joseph believed that by providing a better life for his slaves--more humane treatment and a chance to better themselves--he could realize more profit than through force alone. As a result, the Davis slaves were housed in two-room cabins that featured "large fireplaces and comfortable porches front and back." What was even more unusual was that Davis allowed his slaves to help themselves to his stocks of grain and meat and allowed them to raise chickens for personal use or to sell for profit. ${ }^{571}$

Davis also gave his slaves more freedom than most slaves enjoyed. Whippings were almost unheard of on the Davis plantations. Instead Joseph, and Jefferson, instituted a system of slave justice in which the slaves themselves judged not only the guilt or innocence of those accused of violating the plantations' rules but the punishment as well. If Davis interfered at all in the process it was only to lessen sentences that he thought were too harsh. ${ }^{572}$

${ }^{569}$ Kenneth W. Stampp, The Peculiar Institution: Slavery in the Antebellum South (New York: Vintage Books, 1956) 86-88 .

${ }^{570}$ Stampp, 172-176 passim.

${ }^{571}$ Davis, Hour, 78; Brian R. Dirck, Lincoln \& Davis: Imagining America, 1809-1865 (Lawrence: University Press of Kansas, 2001) 20.

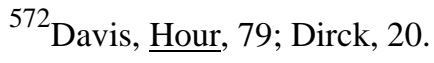


Davis also encouraged his slaves to acquire technical skills and offered them opportunities to earn rewards, either by selling goods to outsiders or by doing extra work for the master. Slaves were given considerable responsibility for running the plantation and Davis also offered bonuses for exceeding quotas. He saw to it that his slaves had adequate medical care, and sent them to specialists in New Orleans for serious ailments and he was famous for his generosity at birthdays, weddings, holidays, and other special occasions. Davis even took the nearly unprecedented step of allowing some slaves to learn to read and write. ${ }^{573}$

Jefferson Davis applied Joseph's ideas to the management of his plantation, Brierfield, and even went his brother one better. He allowed his slaves to select their own names and always made a point of not automatically taking the word of an accuser, even a white accuser, in a dispute with a slave. He allowed slaves to defend themselves and often took their side. On one occasion Davis even armed slaves and used them to drive off some local white hoodlums. ${ }^{574}$

The bottom line, in all of this, is that both Joseph and Jefferson Davis believed that their methods worked, that their slaves were happier and lived better than most of their white neighbors, let alone most slaves. Being surrounded by scenes of devotion from apparently loyal slaves made it easy for Jefferson Davis to believe that his slaves (who naturally stood to benefit from fostering such a belief) were happy and contented and by extension that slaves as a class were better off than the millions of 'wage slaves' crowded into Northern cities. ${ }^{575}$

\footnotetext{
${ }^{573}$ Davis, Hour, 79; Freehling, 498.

${ }^{574}$ Davis, Hour, 80-1; Freehling, 502; Dirck, 20.

${ }^{575}$ Davis, Hour, 79, 219; Dirck, 20.
} 
But it is important to remember, in assessing the merits of the Davis system, that such scenes of devotion, even if sincere, took place within the context of the slave system. Neither Joseph nor Jefferson saw Blacks as equal. Both took a paternal view of slaves as child-like and unsophisticated. It was the not only the right, but the obligation, of the master to exercise parental authority over these "children.' While both men allowed their slaves to determine their own punishment for breaking the rules, through the "slave courts" there was no corresponding "slave congress" to determine what those rules were. That god-like power, the power of law giver, was the prerogative of the Master alone. ${ }^{576}$

This view of blacks as child-like of course influenced Jefferson Davis's character as a man. Contemporaries often commented on his ability to communicate with and relate to his slaves. As William C. Davis points out, Jefferson Davis often found it easier to relate to 'inferiors' such as "slaves, children, women" that to 'equals', i.e. white males. Because these 'inferiors, in the patriarchal society of the antebellum South, were required to be deferential toward white males, Davis could deal openly and generously with them. But with 'equals' Davis had a harder time. White males were of course not required to be deferential, and therefore Davis found them threatening and hard to deal with. Davis was often frustrated by the failure of others to defer to his desires. ${ }^{577}$

Contemporaries and scholars alike have commented on this facet of Davis's character, and he is often described as possessing an haughty personality. In fact if Davis possessed a dominant personality trait it was, at least in the view of his contemporaries, his stubborn and

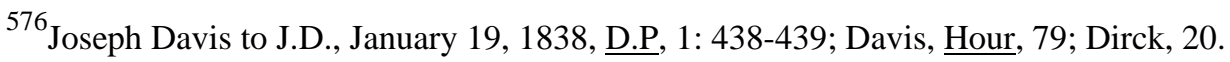

${ }^{577}$ Davis, $\underline{\text { Hour, }} 219$.
} 
combative nature. In 1832, shortly after he met Sarah Knox Taylor, Davis got into a bitter conflict with her father, Colonel Zachary Taylor, over a relatively minor incident that occurred at a court-martial on which they both sat. Although Davis and Taylor eventually reconciled and became close friends, the incident advanced to the point where Davis almost challenged Taylor to a duel. ${ }^{578}$

Like most members of the planter class, Davis placed a high value on personal honor and was well acquainted with the code-duello. Davis had his first direct experience with dueling in February 1838, while he was in Washington D.C. seeking readmission to the army, when he acted as a second for Congressman Jonathan Culley of Maine when Culley was killed in a duel with Congressman William Groves of Kentucky. ${ }^{579}$ Davis himself never fought in a duel, although he did have several close calls over the years. Probably the closest that Davis ever came to dueling was in February 1850 and involved an Illinois congressman named William Bissell who was spreading rumors regarding Davis's service in Mexico. The dispute probably would have reached the dueling ground had it not been for President Taylor who posted guards outside of each man's home to keep them apart. ${ }^{580}$

\footnotetext{
${ }^{578}$ R. Jones, Adjutant General, “Special Order No. 108,” July 21, 1832, D.P., Vol. 1, 249; Robert Anderson, Lt and Assistant, Inspector General, "Muster Roll Book," September 5, 1832, D.P., Vol. 1, 254-55; Life, 4-5; Shelton, 64-5, 66, 69, 74-77, 79, 98-99; Eaton, 21; Cooper, 48, 53-4, 64-72; Allen, 71-5.

${ }^{579}$ Florida McCalab to J.D., October 15, 1837, D.L. 13; “Marriage Register, Louisville, Kentucky,” June

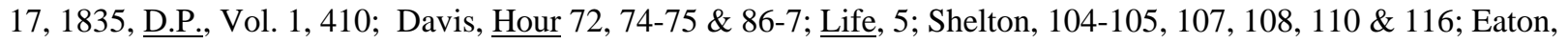
19 \& 22-23; Cooper, 68-72, 76-77, 81 \& 86.

${ }^{580}$ The duel was averted partly through the intervention of James Shields, with whom Lincoln almost fought a duel in 1842. J.D. to William Bissell, February 22, 1850, D.P., Lynda Lasswell, et al. eds., 10 Vols. (Baton Rouge: Louisiana State University Press, 1971-1999) 4: 79-80; William H. Bissell to J.D., February 22, 1850, D.P., 2: 80-81; J.D. to William H. Bissell, February 23, 1850, D.P. 2: 81; J.D. to Bissell, February 27, 1850, D.P. 2: 86; Davis, $\underline{\text { Hour, }}$ 196; Dirck, 62.
} 
There were at least two other occasions when Davis, at least according to rumor, came close to a duel. During Davis's tenure as Secretary of War, it was persistently rumored that Davis had challenged Senator Robert Toombs of Georgia to a duel over accusations that Davis was a disunionist. In June 1855, Davis got into a confrontation with his "friend" Judah P. Benjamin. On this occasion, however, Davis was the challenged party. Bloodshed was again averted through intervention, this time by New York Senator William H. Seward. ${ }^{581}$

While Davis never actually fought a duel he remained very ‘touchy' on matters of personal honor. Like his hero Andrew Jackson, Davis possessed a very combative nature and was never hesitant to resort to physical combat in order to defend his 'good name.' Davis's combative nature came to the forefront during his Senate service when, after less than a month in office, he became enmeshed in an extremely bitter personal dispute with his fellow Mississippi Senator Henry S. Foote. The argument, which began in the Senate Chamber as a disagreement over popular sovereignty, soon moved to nearby Gadsby’s Tavern where, fueled by alcohol, it quickly degraded into crude personal insults and finally into violence with Davis pummeling Foote with a cane over a particularly nasty remark that Foote had made. It finally ended with Davis being pulled off of Foote amid shouted threats of a duel. ${ }^{582}$

In June, 1848, Davis and Foote collided again. Again there were rumors of a duel. The duel never took place, but the two men remained bitter enemies. ${ }^{583}$ In 1851 , when Davis was

\footnotetext{
${ }^{581}$ In June, 1858, Davis joined with Seward to prevent a duel between Senator Henry Wilson of Massachusetts and Senator William Gwin of California.. J.D. to Joseph Emory Davis, January 1, 1838, D.P., Vol. 1, 434; Davis, Hour 87-8, 263 \& 264; Shelton, 116-117; Dirck, 178.

${ }^{582}$ Davis, $\underline{\text { Hour, }} 171$.

${ }^{583}$ Davis, Hour, 171-3, 178, 184, 264; Eaton, 68.
} 
asked to run against Foote for governor in place of his old Division Commander, John A.

Quitman, Davis and Foote hurled insult after insult at each other. The feud even continued after the election when Foote used his inaugural address to launched an extended personal attack against Davis, supposedly in retaliation for remarks that Davis had made during the campaign's final days. ${ }^{584}$

Still it is difficult to precisely gauge Davis's attitude toward dueling. While Davis's reluctance to challenge Foote directly may have been partly a matter of moral philosophy (Davis was an active member of the Mississippi Antiduelling Society) it may also have been the case that Davis did not consider Foote to be worthy of a challenge. The fact that Davis almost dueled with Bissell, a Yankee, and later assaulted Foote with a cane, in much the same manner that Preston Brooks assaulted Charles Sumner, clearly indicates that, at least as far as Jefferson Davis was concerned, not all southern whites, and not even all planters, were 'gentlemen. ${ }^{585}$ And since dueling, as was noted before, was intended to settle disputes among gentlemen, Davis considered Foote neither a gentleman nor worthy of a challenge.

But by no means should Davis's reluctance to engage in dueling be interpreted as a lack of courage. Jefferson Davis was no coward. Davis was a West Point graduate and served with distinction in the Mexican War, both in keeping with the Southern warrior tradition. During his service in the Mexican War, Davis earned a reputation for courage and bravery under fire, as

${ }^{584}$ J.D. to David L. Yulee, July 18, 1851, D.P., Vol. 4, 218; Ethelbert Barksdale to J.D., September 19, 1851, D.P., Vol. 4, 222-23; V.D. to William Burr Howell and Margaret Howell, October 25, 1851, D.L., 63-64; J.D. "Speech at Athens, Mississippi", October 27, 1851, D.P., Vol. 4, 231-232; Reuben Davis to J.D., November 1851, D.P. Vol. 4, 232-33; Davis, Hour, 211-212, 213-216; Eaton, 78-79 Cooper, 209-215, 219-222; Freehling, 526-28, J.D. to William R. Cannon, Washington D.C., December 13, 1858, D.P., Vol. 5, 52-53; Davis, Hour, 217.

${ }^{585}$ Collin S. Tarpley to J.D., Jackson, Miss., May 6m 1853, D.P., Vol. 5, 12-14; Davis, Hour, 252. 
well as for being a stern disciplinarian. At the Battle of Monterrey, on September 22, 1846, Davis led his regiment, the First Mississippi Infantry, into combat while still dressed in civilian clothes and carried out a bold assault that secured a victory for Taylor's army. At Buena Vista, the First Mississippi outdid themselves and suffered a casualty rate of more than one-third: thirty-nine killed and fifty-six wounded, the highest in Taylor's army. Davis himself was numbered among the wounded and spent the next two years on crutches. Davis was also personally commended by Taylor for his "gallantry in battle."

But even Davis’s Mexican War service was not without controversy. In February 1847, Davis became involved in a serious dispute with his second-in-command, Major Alexander McClung, and with Colonel William Campbell of the First Tennessee, over who really deserved credit for the success of the attack at Buena Vista Beside the falling out with his second-incommand, Major McClung, several officers complained about Davis's imperious nature. Davis for his part was so concerned about his public image and so determined to promote himself as a war hero that while home on leave he wrote an angry letter to a Mississippi newspaper that demanded that the editor retract a story that gave credit for the victories to the First Tennessee and its commander, Colonel William Campbell. ${ }^{587}$

${ }^{586}$ V.D. to Margaret Howell, June 6, 1846, D.L., 38-39; J.D. to Lucinda Davis Stamps, July 8, 1846, D.L., 40; General Zachary Taylor to J.D., August 3, 1846, D.L., 41; Joseph Davis Howell, to Margaret Howell, October 13, 1846, D.L., 43; J.D. to Joseph Davis, September 7, 1846; D.L., 42-43; Davis, Hour 127-135, 136, 137-140, 145, 153, 159-60; Life, 6-13 passim; Eaton, 59-62, 63-4, 66; Cooper, 133-141; Shelton, 142, 183-84, 190, $192-93$.

${ }^{587}$ V.D. to Margaret Howell, January 3, 1847, D.L. 45; J.D. to V.D., February 25, 1847, D.L., 47; J.D., "Speech at Natchez," June 14, 1847, D.P., Vol. 3, 183-84; Davis, uour, 146-147, 149-50, 152, 153, 159-160; Eaton, 62, 64-5; Cooper, 144-46, 150. 
The issue resurfaced years later, in 1850, when Davis, by then a Senator, almost fought a duel with Congressmen Bissell of Illinois. ${ }^{588}$ As a politician Davis was often described as being "hypersensitive" to criticism both from the press and from his colleagues. It only made matters worse that often, rather than ignore such criticism, Davis unwisely chose to respond to it. ${ }^{589}$ William C. Davis perhaps best summarized Davis's stubborn nature when he wrote:

Challenged, he would not back down; assaulted verbally, he could not control an instinct to respond with a superior officer. After the fact, though he might confess yielding to the heat of the moment, something in his character stopped him short of admitting error. 'I was right,' he said, and would say again and again. ${ }^{590}$

Perhaps the best illustration of this aspect of Davis's personality is provided by the feud that Davis carried on during his tenure as Secretary of War with General Winfield Scott. ${ }^{591}$ This episode which was highly illustrative of Davis's stubborn and unbending nature, began when Davis denied, on a minor technicality, Scott's application for reimbursement for travel expenses. The denial of Scott's request was a mere pretext, the dispute between the two men had been brewing for years. Davis's close relationship with Scott's bitter enemy and chief rival Zachary

\footnotetext{
${ }^{588}$ Davis, Hour, 196; Dirck, 62.
}

589 "Notice of a Public Meeting on the Annexation of Texas-Speech by Jeff. Davis," July 7, 1845, D.P., Vol. 2, 294-95; "Notice of a Political Meeting-Speeches by Jeff. Davis, Mark Valentine, and Patrick W. Thompkins" August 16, 1845, D.P. Vol. 2, 315-17; "Notice of a Political Meeting-Speech by Jeff. Davis," September 2, 1845, D.P. Vol. 2, 324-25; "Notice of a Political Meeting-Speech by Jeff. Davis," September 4, 1845, D.P. Vol. 2, 327-28; "Notice of a Political Meeting-Speeches by Jeff. Davis and Stephen Cocke," October 3, 1845, D.P., Vol. 2, 351-52; Davis, Hour 109-111, 113, 114- 116; Shelton, 137; Eaton, 51-2.

\footnotetext{
${ }^{590}$ Davis, $\underline{\text { Hour, }} 53$

${ }^{591}$ Davis, $\underline{\text { Hour, }} 228$.
} 
Taylor, and some unflattering comments made by Davis when Scott ran for president in 1852 meant the two were predisposed to dislike each other. ${ }^{592}$

Rather than try to reach to a reasonable solution, the two chose to spend the next two years in a rather pointless debate over the issue. Seemingly for no other reason than to provoke Scott, Davis further stirred the pot when he denied Scott's request for additional pay commensurate with his rank of brevet lieutenant general. Scott, miffed, moved his headquarters to New York. Although the two men rarely saw each other thereafter, they still carried on their feud through a series of increasingly insulting and childish letters. Scott on one occasion called Davis an "enraged imbecile" and Davis replying "I have ceased to regard your abuse, and as you present nothing in this letter which requires remark, I am gratified to be relieved from the necessity of further exposing your malignity and depravity."

Relations between the two men reached their nadir in July, 1855, when Scott granted a four month leave to a subordinate on grounds that Davis felt were unjustified. When Scott refused to explain his reasons for granting the request, Davis responded with a lengthy letter in which he lectured Scott "on the proper relation of the general-in-chief to the secretary of war." 594 From there matters descended into childish insults. This sorry affair finally ended in Spring, 1856, when both men seemed to tire of the matter. But by then word of the feud had gotten into

${ }^{592}$ Ibid.

${ }^{593}$ J.D. to Winfield Scott, War Department, Washington, D.C. May 27, 1856, D.P., Vol. 6, 25. Davis, Hour, 229.

${ }^{594}$ J.D. to Winfield Scott, War Department, Washington, D.C., July 12, 1855, D.P., Vol. 5, 114. 
the press which took great relish in exposing the internal dissension and weakness of the Pierce Administration. ${ }^{595}$

What stands out about the dispute with Scott and with Foote for that matter, was the sheer pettiness of those involved. Many of the exchanges were just plain childish. In the end these episodes proved an embarrassment to everyone involved. In fact when reading the letters between Davis and Scott one can scarcely believe that they were written by grown men. ${ }^{596}$ For individuals who placed such a high value on "honorable" manhood, such childishness may at first glance seem out of character. But more than one observer has commented on Southerners' "touchiness" on matters of honor. Indeed this "touchiness" resembles nothing so much as the juvenile truculence of the schoolyard bully who preys on the weak and who never forgets an insult. $^{597}$

The real tragedy is that Davis, at least, seemed to learn nothing from the experience with Scott. Throughout his political career, and even as Confederate president, he continued to carry on a series of very public political feuds that accomplished little other than to undermine both Davis's political career and, later, the Confederate cause as well. ${ }^{598}$

${ }^{595}$ Davis, $\underline{\text { Hour, 202, 217, 228-230, } 263 .}$

${ }^{596}$ J.D. to Winfield Scott, War Department, Washington, D.C., July 12, 1855, D.P., Vol. 5, 114; Davis, Hour, 202, 217, 228-230, 263. 217.

${ }^{597}$ J.D. to William R. Cannon, Washington D.C., December 13, 1858, D.P., Vol. 5, 52-53; Davis, $\underline{\text { Hour, }}$

${ }^{598}$ Among the individuals with whom Davis became involved in "petty arguments" over the years, were Senators Solomon Downs and Judah P. Benjamin, bot of Louisiana, Sam Houston of Texas and Zachariah Chandler of Michigan. Davis, Hour, 202, 217, 229-230, 263. 


\section{CHAPTER 7}

\section{ABRAHAM LINCOLN}

Of the four individuals under consideration Lincoln is, by far, the most well-known. Indeed Lincoln's life story is so familiar and so well documented that it hardly_needs to be recounted in full. As a subject of historical inquiry, the public's fascination with Lincoln presents both advantages and disadvantages to the researcher. On the one hand because Lincoln is so popular, he is a subject in which people are interested and one_with which even the casual reader can relate. On the other hand Lincoln is so admired that, much like his contemporary, Robert E. Lee, Lincoln has been dehumanized. In other words Lincoln has been lionized to the point where he seems less a human being than a face on Mount Rushmore. But of course Abraham Lincoln was both a human being and a man, and like most men of the antebellum era, he was strongly influenced by contemporary concepts of manhood.

Abraham Lincoln was born February 12, 1809, near Hodgenville, Kentucky, the first son and second child of Thomas and Nancy Hanks Lincoln. ${ }^{599}$ In 1811, when Lincoln was about two-years-old his family moved to nearby Knob Creek, Kentucky and then in December 1816, to

\footnotetext{
${ }^{599}$ Lincoln had two siblings: an older sister, Sarah, and a younger brother, Thomas, who died in infancy. Abraham Lincoln to Jesse W. Fell, Enclosing Autobiography, Springfield, December 20, 1859 (Hereafter, "Fell Autobiography"), Abraham Lincoln: Selected Speeches and Writings (hereafter Speeches and Writings) (New York: Vintage Books, 1992) 238; "Autobiography Written for Campaign," (hereafter "Campaign Autobiography”) June, 1860, Speeches and Writings, 264; An Autobiography of Abraham Lincoln, Consisting of the Personal Portions of his Letter, Speeches and Conversations, Compiled and Annotated by Nathaniel Wright Stephenson (Indianapolis: The Bobbs-Merrill Company, Publishers, 1926, (Hereafter Lincoln Autobiography), 1; David Herbert Donald, Lincoln (New York: Touchstone Books: 1995) 19-22; William Hanchett, Out of the Wilderness: The Life of Abraham Lincoln, (Urbana: The University of Illinois Press, 1994) 5; 19-21.
} 
Spencer County, Indiana. ${ }^{600}$ Nancy Hanks Lincoln died in 1818 and about a year later Thomas Lincoln married Sarah Bush Johnston, a widow with three children of her own. ${ }^{601}$

Having grown up on the frontier and experienced the struggle for survival that prevailed there, Lincoln was exposed from an early age to the rough-and-tumble image of manhood associated with the frontier. Lincoln was not only exposed to the masculine virtues of the frontier, but he actively embraced those virtues in both his personal life and in his political career. Among the most honored qualities of frontier masculinity were physical strength and hard work. Certainly hard work was a concept with which Abraham Lincoln was very familiar. Lincoln went to work at an early age helping his father with planting, hoeing, chopping wood and other assorted farming chores. Lincoln's father later hired him out to neighbors for whom he split fence rails, plowed fields, butchered pigs and performed other tasks. Lincoln continued to do this kind of work, off and on, until age twenty-three. Lincoln also made money doing assorted jobs along the river. ${ }^{602}$ It should be noted that although Lincoln claimed to loathe physical labor he never failed to exploit his "rail splitter" image when it was to his advantage to do so. ${ }^{603}$

600“Fell Autobiography,” 238; “Campaign Autobiography,” 265; Lincoln Autobiography, 2; Stephen B. Oates, With Malice Toward None: The Life of Abraham Lincoln (New York: Mentor Books, 1978) 7; Donald, Lincoln, 22- 23; Hanchett, 6.

601“Campaign Autobiography,” 265; Lincoln Autobiography, 4; Hanchett, 7

602“Campaign Autobiography, 265; Lincoln Autobiography, 6; Oates, 7; Michael Burlingame, The Inner World of Abraham Lincoln (Chicago: The University of Chicago Press, 1994) 37; John G. Nicolay and John Hay Abraham Lincoln: A History vol. 1 (New York: The Century Company, 1886 \& 1890) 34-36, 43-45, 48, 77-78; Henry J. Raymond, The Life and Public Services of Abraham Lincoln, Sixteenth President of the United States, together with his state papers, including his speeches, addresses, messages, letters, and proclamations, and the closing scenes connected with his Life and Death, (New York: Darby and Miller Publishers, 1865) 19-20; Hanchett, 6, 8-9.

\footnotetext{
${ }^{603}$ Abraham Lincoln (hereafter A.L.) to Thomas Lincoln and John D. Johnston, December 24, 1848,
} 
A good example of this occurred during Lincoln's second race for the Illinois State Legislature in 1834 when he encountered a group of about thirty men at work harvesting grain. As related by Lincoln's law partner, William Herndon, the members of the group informed Lincoln that they "would never vote for a man who could not hold his own in the field," to which Lincoln replied: "Boys, if that is all I am shure (sic) of your votes." According to Herndon, Lincoln then picked up the cradle and "led the harvesters on one full round of the field." Herndon concluded: "The Boys was satisfied and I don't think he Lost a vote in the Croud(sic)."604

This was not the first occasion on which Lincoln had found it necessary to prove that he measured up to contemporary standards of manhood. The ability, or at least the willingness, to fight, was another important aspect of masculinity associated with the frontier. Just as physical strength was honored in the ability to labor long and hard, so was it honored in the capacity to use one's fists. Again, Lincoln was not found wanting. His skill as a wrestler and ability to perform feats of physical strength, such as holding an ax parallel to the ground, were nearly as well known as his skill as a rail-splitter and nearly as useful politically. Soon after his arrival in the village of New Salem, Lincoln's skill as a fighter, and by extension his manhood, were put to the test in a confrontation with "a crowd of ruffianly young fellows who were called the ‘Clary's Grove Boys."”605

Speeches and Writings, 77-78; Louis A. Warren, Lincoln's Youth: Indiana Years: Seven to Twenty-One, 1816-1830 (Indianapolis: Indiana Historical Society, 1959) 27; Dirck, Imagining America, 16; Oates, 190-191.

${ }^{604}$ Donald, Lincoln, 52.

605“Fell Autobiography,” 239; “Campaign Autobiography,” 266; Nicolay and Hay, History, vol. 1, 78, 79; Raymond, Life, 24; Hanchett, 12-14; Oates, 20. 
The Clary's Grove Boys knew something about frontier masculinity even if they probably did not possess the verbal skills to express those ideas. Variously described as uninhibited and ignorant, cruel and sympathetic, loyal yet ready to fight at a moment's notice, they were avid devotees of many of the masculine pastimes of the day including cock-fighting, gander-pulling, wrestling, and drinking. The Clary's Grove Boys were most of all brawlers and were contemptuous of anyone not skilled in the 'manly arts.' The toughest of all of them, and therefore their leader, was a goliath named Jack Armstrong. Having heard about the new arrival in town who was said to be not only hard working but also intelligent, Armstrong challenged Lincoln to a wrestling match. Lincoln initially did not want to accept the challenge but concern for his reputation and a desire to win the community's acceptance forced him to participate. ${ }^{606}$

A great deal of controversy surrounds the outcome of the match. Exactly what happened and even who won remain in question. At the time some alleged that Armstrong won fair and square, others claimed that Lincoln had Armstrong beaten until the latter resorted to cheating. In any case, who won did not really matter. What mattered was that Lincoln proved that he was no coward to both the community of New Salem and especially to the Clary’s Grove Boys who thereafter came to admire Lincoln and often accompanied him to political rallies where they acted as a sort of informal bodyguard. ${ }^{607}$

Lincoln frequently needed bodyguards as the combative nature of frontier life often carried over into politics. Over the years Lincoln witnessed many acts of political violence and

${ }^{606}$ Nicolay and Hay, History, vol. 1, 79-80; Hanchett, 16.

${ }^{607}$ Shortly after the encounter with Jack Armstrong, Lincoln defeated Daniel Needham, who was the local wrestling champion at nearby Wabash Point, on the Mississippi River. L.M. Greene to William Herndon, July 30, 1865, in Herndon's Informants, 40-41; Nicolay and Hay, History, vol. 1, 80-81; Hanchett, 16; Burlingame, Inner World, 159. 
was even involved in a few himself. During his first run for the state legislature in 1832 Lincoln, while delivering a speech in Pappsville, Illinois, saw one of his supporters in the audience being attacked. Lincoln leaped from the stage, waded into the crowd and, according to witnesses, tossed the assailant twelve feet through the air. On another occasion Lincoln became so incensed by an opponent's accusation that he opposed the repayment of a state loan that he referred to the offender as "a liar and a scoundrel" and threatened to "give his proboscis a good wringing."608 The effectiveness of such appeals to frontier masculinity in garnering political support are illustrated by the following passage from an 1860 Republican political tract that extolled the manly virtues of the party's candidate. Clearly the image that it conveys of Lincoln is that he was 'one of the boys' and was in no way a 'dandy':

Probably no attribute of our candidate will, after all, endear him so much to the popular heart as the conviction that he is emphatically 'one of the people.' His manhood has not been compressed into the artificial track of society; but his great heart and vigorous intellect have been allowed a generous development amid his solitary struggles in the forest and the prairie. With vision unobscured(sic) by the mists of sophistry, he distinguishes at the first glance between what is true and what is false, and with will and courage fortified by his life of hardship, he is not the man to shirk any responsibility, or to shrink from any opposition. ${ }^{609}$

As discussed in Chapter Two economic success was another important measure of manhood. Like many of his contemporaries, both in the Northwest and throughout the Northern states, Lincoln placed a very high value upon social mobility and economic independence and of course associated those values with manhood. Almost from the time he could think for himself

${ }^{608}$ Donald, Lincoln, 46 \& 60.

${ }^{609}$ Abraham Lincoln, David W. Bartlett, Life and Public Services of Hon. Abraham Lincoln, with a Portrait on Steel, To which is Added a Biographical Sketch of Hon. Hannibal Hamlin, (New York: H. Dayton, 1860) 148, accessed through Illinois Historical Digitization Projects, Northern Illinois University Libraries, Copyright 2001. \{http://lincoln.lib.niu.edu/cgi-bin/contextualize_?p.2475./lib35/artfl!/databases/sources/IMA. 
Lincoln yearned to escape his father's authority and make something of himself. ${ }^{610}$ Unlike many in the Northwest, however, who yearned for land or to learn a trade, Lincoln desired to rise above his circumstances and enter the professional class, specifically the legal profession. ${ }^{611}$

In Lincoln's time as in our own, education was the key to economic and social advancement. In this regard Lincoln faced a very severe handicap. Lincoln's education was spotty. This was largely a function of circumstance. Life on the Indiana and Illinois prairie left little time for advanced learning. Indeed, it is a testament to Lincoln's considerable intellectual gifts that he became as learned and erudite as he did. He first attended school in 1815 and 1816 when he spent about a month at an "A.B.C. School" where he learned such rudiments as "spelling, reading, and indifferent writing" and "“ciphering' to the rule of three." The quality of instruction at these schools left much to be desired. In fact the main qualification for teachers seems to have been the ability to "thrash any boy or youth that came to (the) school." Lincoln himself later condemned these schools as being hopelessly inadequate, the instructors were incompetent, the facilities unforgivable. "There was absolutely nothing," Lincoln said, "to excite ambition for education." ${ }^{612}$

${ }^{610}$ Etcheson, "Manliness," 59-62 \& 65; Leverenz, Manhood, 1-4; Rose, "Hoosier Origins," 202-32; Foner, Free Soil, 13-14; Baker, "Belief ," 538; Basch, "Marriage," 892-894.

${ }^{611}$ Foner, Free Soil, 12-13, 16-17, 23; Colin Creighteon, "The Rise of the Male Breadwinner Family: A Reappraisal," Comparative Studies in Society and History, Vol. 38, No. 2 (April, 1996), 323; Ira Berlin, Herbert G. Gutman, "Natives and Immigrants, Freemen and Slaves: Urban Working Men in the Antebellum American South," The American Historical Review, Vol. 88, No. 5, (December, 1983) 1193. 11.

612 “Fell Autobiography,” 239; “Campaign Autobiography,” 265-6; Lincoln Autobiography, 4-5,7; Oates, 
Altogether, as Lincoln reckoned it, his formal education probably amounted to less than one full academic year. ${ }^{613}$ The remainder of Lincoln's education consisting largely of reading books that included The Pilgrim's Progress, Aesop's Fables, Robinson Crusoe, William Scott's Lessons in Elocution, William Grimshaw's History of the United States, Benjamin Franklin's autobiography, Dilworth’s Spelling-Book, Samuel Kirkham's English Grammar, Paine’s Age of Reason, Constantin de Volney's Ruins of Civilizations, Shakespeare, Robert Burns, Oliver Wendell Holmes, and possibly Voltaire. Lincoln also taught himself mathematics. Although he claimed not to care for history or biography, perhaps the most influential book that Lincoln read in his youth was Parson Weems's Life of George Washington. ${ }^{614}$ Lincoln's efforts at selfeducation intensified after he moved to New Salem in 1831. His position as town post-master afforded him ample opportunity for reading newspapers and he sharpened his reasoning and public speaking skills by joining the New Salem Debating Society and taught himself surveying. ${ }^{615}$

In preparation for his legal career Lincoln read the standard legal texts of the time-Revised Statutes of Indiana, Blackstone's Commentaries, Chitty's Pleadings, Greenleaf's Evidence, Joseph Story's Equity Jurisprudence--and studied the Constitution and Declaration of Independence. ${ }^{616}$

\footnotetext{
613“Campaign Autobiography,” 265-6.

${ }^{614}$ Donald, Lincoln, 29-33, passim; Nicolay and Hay, History vol. 1, 35; Raymond, Life, 22; Oates, 12, 22, $\& 31$.

${ }^{615}$ Donald, Lincoln, 36, 41 \& 51; Oates, 31.

${ }^{616}$ Lincoln Autobiography, 7, 12; Donald, Lincoln, 53-55; Nicolay and Hay, History, vol. 1, 35; Hanchett, 9-10, 12; Oates, 13, 16, 26, 28, 29 \& 30.
} 
In March, 1832, Lincoln announced his candidacy for the state legislature. Lincoln, who was largely unknown outside of New Salem, compensated for his lack of exposure by taking his campaign directly to the people, engaging in a direct, person-to-person, campaign ${ }^{617}$ However, Lincoln's budding political career was interrupted by the outbreak of the Black Hawk War. Although Lincoln was elected captain of his local militia company, overall his military service was "neither particularly dangerous nor heroic."618 Lincoln saw no fighting in the 51 days he spent in the service. ${ }^{619}$ When Lincoln returned to New Salem in July, 1832, there were only two weeks left until the August election. With little time to campaign, Lincoln finished eighth out of thirteen candidates. ${ }^{620}$

Adding to Lincoln's frustration was the fact that the store that he had been managing for a local business man named Denton Offut had failed in the Spring. ${ }^{621}$ Luckily two local merchants agreed to sell their general store and stock of merchandise to Lincoln and another man named William Berry, who both signed notes for the store. This store also failed and when Berry died

${ }^{617}$ Abraham Lincoln, "To the People of Sangamon County," March 9, 1832, Speeches and Writings, 3-7; "Campaign Autobiography, 268; Donald, Lincoln, 42-3; Hanchett, 16.

${ }^{618}$ Donald describes an incident when Lincoln resorted to physical force to preserve discipline: "When an old Indian, bearing a certificate of good character from American authorities, stumbled into camp, Lincoln's men talked of killing him, saying, 'The Indian is a damned spy' and 'We have come out to fight the Indian and by God we intend to do so.' Drawing himself up to his full height, Lincoln stepped in front of the shivering Indian and offered to fight anyone who wanted to hurt the old man. Grumbling the soldiers let the Indian slip away." Donald, Lincoln, 44; Brig. Maj. John J. Hardin, "Receipt for Arms," April 28, 1832, The Complete Works of Abraham Lincoln vol. 1, John J. Nicolay and John Hay, eds, (New York: Francis D. Tandy Company, (1894, 1905), (hereafter Complete Works) 9-10.

619“Autobiography,” 239; Lincoln Autobiography, 9-11.

620“Autobiography,” 239; “Campaign Autobiography,” 268; Lincoln Autobiography, 9-11; Donald, Lincoln, 44-6.

621“Campaign Autobiography,” 267; Lincoln Autobiography, 8-9; Donald, Lincoln, 36-37, 38, 39, 41; Hanchett, 12-14. 
two years later Lincoln was left to pay off the partners' $\$ 1,100$ in debts. This episode has traditionally, and rightly, been cited as an example of Lincoln's honesty, but it could also be interpreted as an example of the masculine virtue of personal honor. So concerned was Lincoln with reputation and with maintaining his 'good name' before the community that even though he was legally responsible for only half the debt, Lincoln insisted on repaying all of it. ${ }^{622}$

Lincoln moved to Springfield, Illinois, in April 1837. At the time he was so poor that he could not even afford a room. A local storekeeper, and fellow Kentuckian, Joshua Speed offered to share quarters until Lincoln got on his feet. For four years, until 1841, the two men shared a double bed and Speed became perhaps Lincoln's closest friend. Much has been made of this arrangement, one recent biographer cites it as evidence of Lincoln's alleged homosexuality. There is little evidence to support the allegation other than the fact that the two men shared a bed, which was a common practice at the time, one necessitated by a lack of beds on the frontier. ${ }^{623}$

After moving to Springfield, Lincoln’s legal career began to prosper. After Lincoln’s first law partner, John T. Stuart, won election to Congress in 1838, Lincoln teamed up with Stephen T. Logan, the most respected lawyer in Sangamon County. ${ }^{624}$ Under Logan's tutelage Lincoln’s legal education broadened considerably. In 1844 Lincoln started his own firm with William H.

622“Campaign Autobiography,” 268; Lincoln Autobiography, 11-13; Raymond, Life, 26; Hanchett, 16-17.

${ }^{623}$ Abraham Lincoln to Mary Speed, Bloomington Illinois, September, 27, 1841, Speeches and Writings, 28-30; A.L. to Joshua F. Speed, Springfield, July 4, 1842, Speeches and Writings 47-49; "Campaign Autobiography," 269; Lincoln Autobiography, 22-23; Hanchett, 21-22.

${ }^{624}$ Lincoln Autobiography, 13-16; Donald, Lincoln, 52-5, 58-9, 64. 
Herndon. The partnership was very successful. Lincoln and Herndon were involved in about 5000 cases, including more than 300 appeals to the Illinois State Supreme Court. ${ }^{625}$

Much of the firm's practice involved riding the circuit of the Eighth Judicial District of central and eastern Illinois. Because most lawyers, Lincoln included, could not make a living only on the cases they encountered in Springfield, it was necessary to travel the circuit for three months in the spring and for three months in the fall. Lincoln traveled the circuit far longer than what would normally be expected of a senior partner. Part of the reason for this was that he needed the money. Aside from that, Lincoln enjoyed life on the road and male camaraderie of his fellow attorneys and judges. He especially enjoyed socializing in the evenings after the court adjourned. $^{626}$

Lincoln eventually became one of the foremost railroad lawyers in Illinois. When David Davis was elected judge of the Eighth Judicial District he had so much confidence in Lincoln that he often designated Lincoln to preside in his stead when called away from the bench by family illness or some other emergency. ${ }^{627}$ But no matter how far he rose, socially or economically, Lincoln was careful never to become a 'dandy.' Lincoln was certainly aware of the fact that those who did not perform physical labor, such as bankers, were seen as unmanly and he made it a point to remain 'one of the boys', even after he entered the White House. ${ }^{628}$ In

\footnotetext{
${ }^{625}$ A.L. to John T. Stuart, Springfield, January 20, 1841 and A.L. to John T. Stuart, Springfield, January 23, 1841, both in Speeches and Writings 26 and 27-28 respectively; Hanchett, 25-28; Frank J. Williams, Judging Lincoln (Carbondale and Edwardsville: Southern Illinois University Press, 2002) 38-39.

${ }^{626}$ Donald, Lincoln, 73, 106; Hanchett, 28.

${ }^{627}$ Donald, Lincoln, 146 \& 147.

${ }^{628}$ Etcheson, “Manliness,” 75.
} 
this regard Lincoln's sense of humor and talent for spinning yarns were an important asset and in large measure account for his great popularity with the public, then and now. In addition to their entertainment value, Lincoln's stories provided an emotional release to teller and audience alike and were an effective way of illustrating a point. But beyond even that the ability to laugh and to tell jokes was an important component of antebellum male culture. In short, Lincoln's stories, which were often downright lewd, helped assure his continued acceptance in the predominantly male society of the Northwest. ${ }^{629}$

In discussing Lincoln's legal career it is worth mentioning the McCormick Reaper Case, in which Lincoln became involved during 1855 . The case involved a patent infringement suit filed by Cyrus McCormick against John H. Manny who had illegally copied McCormick’s mechanical reaper. Manny, who was funded by a number of rival manufacturers who hoped to void McCormick's patent, hired a team of high-profile Eastern patent attorneys to contest the suit. When it appeared that the case might be heard by Judge Thomas Drummon of the Federal Court of the Northern District of Illinois, the lead attorney, George Harding of Philadelphia, thought it would be wise to hire an Illinois attorney with experience in Drummon's court. Harding's first choice was Isaac N. Arnold of Chicago, but when he proved unavailable Harding sent an associate, Peter Watson, to Springfield to check out Lincoln. Watson was thoroughly unimpressed with both Lincoln's professional credentials and with his personal style and manners. Rather than offend Lincoln by rejecting him outright, a $\$ 400$ retainer was paid to

\footnotetext{
${ }^{629}$ Abraham Lincoln, "Address to the Washington Temperance Society of Springfield, Illinois," February, 22, 1842, Speeches and Writings, 34-43; Donald, Lincoln 35, 39, 66, 81, 83, 106, 149.
} 
Lincoln and arrangements made for a fee, but neither Watson nor Harding ever contacted him again. $^{630}$

The defense team never sent Lincoln the depositions or any of the other documents associated with the case, nor was he asked to be present at the hearing. They did not even bother to tell Lincoln that the case had been moved from Chicago to Cincinnati where it would be heard by Supreme Court Justice John McLean. ${ }^{631}$ Nonetheless Lincoln took it upon himself to study the case and traveled to Cincinnati for the trial. There he conferred with Harding who, like Watson, was unimpressed. In fact the entire defense team snubbed Lincoln; he was never consulted and never invited to dine with the other attorneys who never even walked to or from the courthouse with him. Worst of the bunch was the Pittsburgh attorney, Edwin McMasters Stanton, who remarked rather cruelly: "Why did you bring that d-d long armed Ape here . . . he does not know anything and can do you no good."632

Lincoln remained in Cincinnati for the week-long hearing, after which he went home, "feeling insulted and indignant." When Harding sent him a check for the rest of his fee, Lincoln at first tried to return it saying that he was not entitled to any payment beyond his original retainer. When Harding resent the check, possibly trying to assuage his conscience, Lincoln finally kept it. Lincoln later summed up his feelings about the matter when he told his partner, Herndon, that he had been "roughly handled by that man Stanton."

${ }^{630}$ A.L. to P.H. Watson, Springfield, July 23, 1855, Uncollected Letters, 58; Donald, Lincoln, $185-186$.

${ }^{631}$ A.L. to Owen Lovejoy, Springfield, August 11, 1855, Speeches and Writings, 100-101; A.L. to Manny \& Co., Springfield, Ill., September 1, 1855, Uncollected Letters, 61.

${ }^{632}$ Donald, Lincoln, 186.

${ }^{633}$ Lincoln later chose Stanton to replace the corrupt Simon Cameron as Secretary of War. William H. 
One is struck by the incredible rudeness and lack of professional courtesy shown Lincoln by other the attorneys, especially Stanton. It clearly illustrates that while he may have lacked their Eastern sophistication and social graces, and may not have been a Harvard graduate, Lincoln could have taught Stanton and the others a great deal about professional standards of behavior (and manhood). It was also an illustration of sectionalism, specifically Eastern attitudes toward Westerners. Obviously, to Stanton and the other eastern attorneys, Lincoln was just as much of a rube as Lincoln's father was to him.

Around the time of his first election to the state legislature in August 1834, Lincoln began his first romantic relationship with a girl named Ann Rutledge whose father owned a tavern where Lincoln sometimes slept. The Ann Rutledge affair is worth exploring in detail both for what it reveals about Lincoln's attitudes toward women and more importantly for what it reveals about the nature of Victorian sexual mores. While there is little evidence to support the notion that Lincoln was homosexual his relations with women were complicated. That Lincoln was heterosexual and had a healthy interest in sex is not to be doubted. It was acting on that interest that caused him difficulty. Lincoln felt awkward around women, especially around eligible women. With married women Lincoln was more at ease, but in the presence of a potential marriage partner he became silent and withdrawn. ${ }^{634}$

Herndon and Jesse W. Weik, vol. 2, Herndon's Lincoln: The True Story of a Great Life, (Chicago: Belford-Clarke, 1890) Vol. 2, 356.

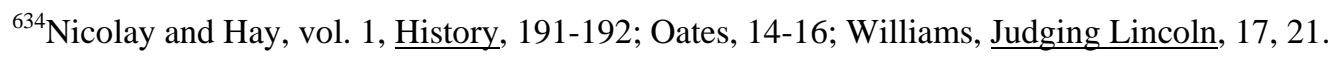


At the time Lincoln first met her, Ann Rutledge was engaged to a man named John McNeill. ${ }^{635}$ McNeill, whose real name was John McNamar, was, to all appearances, a rather shady character. He told Rutledge and her family that he had originated in New York and had come west to win back his family's fortune which his father had squandered. But something in McNamar's story did not add up. If it was McNamar's purpose to amass a 'fortune', why would he come to a backwater like New Salem where the chances of striking it rich were remote. McNamar further aroused suspicion with his explanation as to why he had changed his name. McNamar explained that if his family found out where he was, they would track him down and "before he could have accumulated any property would have sunk him beyond recovery."”36

McNamar eventually told Ann that he had to return to New York in order to attend to family affairs. McNamar never returned to New Salem. As it became obvious that McNamar was not coming back Ann's friendship with Lincoln turned into an 'understanding.' Given the moral climate of the time this was a very tricky situation. Technically Ann was still betrothed to McNamar and as such Lincoln was not at liberty to pursue her. To have done so would have placed them both in a very bad moral light in the eyes of the community. Even after the betrothal was formally broken Lincoln had to proceed with caution. As Donald puts it, "in

${ }^{635}$ There is not universal agreement regarding the nature of the relationship involving Lincoln and Anne Rutledge. Donald, and others, allege that there was a romantic attachment between the two, while Lincoln's secretaries, John Nicolay and John Hay, downplay the importance of the relationship and characterize it as no more than a casual friendship. For the purposes of this study the truth of the matter is of little importance. The mythology surrounding the "Lincoln-Rutledge affair", whether true or not, are more important for what they reveal about the nature of antebellum sexual mores than for what they tell us about Lincoln's social life. Lincoln Autobiography, 14; Nicolay and Hay, vol. 1, History, 191-192; Hanchett, 18.

\footnotetext{
${ }^{636}$ Donald, Lincoln, 56; Hanchett, 18-19.
} 
Victorian America, a spurned woman was suspected of having some moral blight."637 For that reason the entire affair had to be kept very quiet lest it create a scandal. But in time Abraham Lincoln and Ann Rutledge apparently became engaged. Soon after the engagement Ann came down with what was diagnosed as "brain fever" (probably typhoid) and died in August 1835. The death threw Lincoln in to a deep depression that persisted for months and had friends worried that he might commit suicide. ${ }^{638}$

In 1836, Lincoln met Mary Owens. After a rather lackluster courtship which Lincoln tried to "weasle" out of several times he finally proposed. Much to his surprise and chagrin, Mary refused. She later explained that "Mr. Lincoln was deficient in those little links which make up the chain of woman's happiness." ${ }^{39}$ When Lincoln asked to get out of the engagement, Mary Owens agreed, which also threw Lincoln into a deep depression. ${ }^{640}$

Finally in 1839 Lincoln met Mary Todd who had come to Springfield to visit her sister, Elizabeth, who was married to local businessmen, Ninian W. Edwards. They became engaged

${ }^{637}$ Donald, Lincoln, 56-7; Hanchett, 18-19.

${ }^{638}$ Lincoln Autobiography, 14; "William G. Greene, interview with William H. Herndon,” August 17, 1887, in Herndon's Informants, 21; Hanchett, 18-19.

${ }^{639}$ On one occasion the two decided to go for a walk, escorted by a local matron, Mrs. Bowling Green who was struggling with "a very fat baby." Lincoln did not offer to help her. A.L. to Mary S. Owens, Springfield, May 7, 1837, Speeches and Writings 10-11; A.L. to Mary S. Owens, Springfield, August, 16, 1837, Speeches and Writings 11-12; A.L. to Mrs. Orville H. Browning, Springfield, April 1, 1838, Speeches and Writings, 22-24; Lincoln Autobiography, 16-18, 21, 22; "William G. Greene, interview with William H. Herndon," August 17, 1887,21; Henry McHenry to William H. Herndon, January 8, 1866, 155-156; Benjamin F. Irwin to William H. Herndon, August 27, 1866, 325; "Isaac Cogdal, interview with William H. Herndon," c. 1865-1866, 440, all in Herndon's Informants; Hanchett, 24-5.

${ }^{640}$ The episode was so humiliating that Lincoln wrote to the wife of close friend Orville H. Browning: "I have now come to the conclusion never again to think of marrying; and for this reason; I can never be satisfied with anyone who would be block-head enough to have me.” A.L. to Mary S. Owens, Springfield, May 7, 1837 (hereafter unless otherwise specified all letters are authored by Lincoln), Speeches and Writings 10-11; A.L. to Mary S. Owens, Springfield, August, 16, 1837, Speeches and Writings 11-12; A.L. to Mrs. Orville H. Browning, Springfield, April 1, 1838, Speeches and Writings, 22-24; Lincoln Autobiography, 16-18, 21, 22; Hanchett, $24-25$. 
and again Lincoln got cold feet and broke the engagement. ${ }^{641}$ Finally, after consulting with Speed and an 'intervention' by the wife of Simeon Francis, on November 4, 1842, Abraham Lincoln and Mary Todd were married. ${ }^{642}$

Lincoln's marriage, like most marriages of the time, was not an equal partnership. This was only to be expected in an era when domestic harmony and the maintenance of patriarchal authority also figured prominently in antebellum ideals of masculinity in the Old Northwest. ${ }^{643}$ The Lincoln marriage was certainly no exception. For the most part household management and daily chores were strictly the province of, and the responsibility of, Mary Lincoln. She cooked, cleaned, did laundry, and made all of her own clothes and those of her children. And yet Lincoln, unlike most nineteenth century patriarchs, made at least some effort to lighten her burden. In fact many residents of Springfield thought that Lincoln was henpecked. ${ }^{644}$ On at least

${ }^{641}$ In Autobiography of Abraham Lincoln editor Nathaniel Stephenson alleged that Lincoln became involved in a "faint love affair" with a girl named Sarah Richard during the time that the engagement with Mary Todd was broken, which he attributes to "a few rather cryptic sentences scattered through the letters of Speed." But as most Lincoln biographies do not mention this alleged affair the story may be apocryphal. Lincoln Autobiography, 33-34; A.L. to Joshua F. Speed, c. early January, 1842 30-32, A.L. to Joshua F. Speed, Springfield, February, 13, 1842, 32-33, A.L. to Joshua F. Speed," Springfield, February 25, 1842 43-44, A.L. to Speed, Springfield, February, 25, 1842, 44-45, A.L. to Speed, March, 27, 1842, 45-47, all in Speeches and Writings; Hanchett, 34-5.

${ }^{642}$ A.L. to Joshua F. Speed, c. early January, 1842 30-32, A.L. to Joshua F. Speed, Springfield, February, 13, 1842, 32-33, A.L. to Joshua F. Speed, Springfield, February 25, 1842 43-44, A.L. to Speed, Springfield, February, 25, 1842, 44-45, A.L. to Speed, March, 27, 1842, 45-47, all in Speeches and Writings; Lincoln Autobiography, 31,33-34, 49; Hanchett, 34-6.

${ }^{643}$ Basch, "Marriage," 892-894; Cott, "Marriage," 1452 \& 1453; Berthoff, "Peasants and Artisans," 582 \& 585; Berlin \& Gutman, 1176-1177; Woodward ed., Chesnut, 31; McCurry, Masters of Small Worlds, 84, 85.

${ }^{644}$ In Judging Lincoln Frank Williams writes of Lincoln's views on domestic affairs in general and women's roles in particular, "Less well documented is how Lincoln treated his wife and Mariah Vance, their Springfield housekeeper. The picture that emerges is that he treated women, whether a well-born Southern belle or a lowly African-American laundress (and her family), with respect, concern and even affection. The Emancipation Proclamation was not an aberration in Lincoln's life, nor was his willingness to support women's rights." William, Judging Lincoln, 23; Donald, Lincoln, 95, 107 \& 159. 
one occasion Mary was reported to have chased Lincoln down the street while armed with a butcher knife. One cannot help but wonder how the latter spectacle affected Lincoln's standing among his fellow males and whether they would have felt contempt for him, for such an unmanly and cowardly display, or pity for having to put up with it in the first place. One possible clue may lie in the attitude of Lincoln's law partner, William Herndon, who despised Mary Lincoln, and once described her as "a terror." "645

Another important facet of Lincoln's family life was his relationship with his sons: Robert Todd Lincoln (born 1843); Edward Baker Lincoln, (born 1846); William Wallace Lincoln (born 1850) and Thomas "Tad" Lincoln (born 1853) ${ }^{646}$ That Lincoln did not have a close relationship with his own father is certainly no secret. Most father-son relationships contain at least some tension but in this case more seems to have been at work than normal parent-child strife. Again the problem may have been at least partially rooted in the patriarchal nature of $19^{\text {th }}$ century domestic relations in which a father's word was literally law and the main obligation of father to son was to provide a proper model of robust, stoic, masculinity. Thomas Lincoln certainly exercised his fatherly prerogative and put young Abraham to work almost as soon as the boy could walk and later hired him out to neighbors. Moreover Thomas kept all of the wages for himself. ${ }^{647}$ By law and by custom, he was entirely within his rights, but he should

\footnotetext{
${ }^{645}$ Donald, Lincoln, 107, 158-159, 160, 572-573; Oates, 81.

${ }^{646}$ Lincoln Autobiography, 61; Donald, Lincoln, 94-6, 152-4, 155-7, 158-9; Hanchett, 18, $36,42$.

${ }^{647}$ Donald, Lincoln, 32.
} 
not have been surprised by Abraham's resentment at such exploitation which amounted to little more than slavery. ${ }^{648}$

Lincoln's cousin Dennis Hanks claimed that education was another source of conflict and that Thomas Lincoln felt that Abraham was "ruining himself" with learning and beat him for reading books. ${ }^{649}$ Others, including Lincoln's stepmother, disputed this claim and argued that Thomas only beat Abraham when reading interfered with his chores. ${ }^{650}$ Whatever the cause, a profound estrangement developed between father and son. When his father died in 1851, Abraham Lincoln did not even attend the funeral. ${ }^{651}$

The contrast in the way that Lincoln related to, and dealt with, his sons was striking. Lincoln did not have a close relationship with his eldest son, Robert Todd Lincoln. While there was not the hostility that characterized relations with Thomas, a certain 'distance' existed between father and son. ${ }^{652}$ Lincoln's relationship with his second son, Edward Baker Lincoln, is harder to gauge since the boy died at a young age, just shy of his fourth birthday. But with his

\footnotetext{
${ }^{648}$ Lincoln's cousin Dennis Hanks, suggested that Lincoln also felt resentment toward the children of Sarah Bush Lincoln. A.L. to John D. Johnston, Washington, December 24, 1848, Speeches and Writings, 77-78; Donald, Lincoln, 152.

${ }^{649}$ As was stated above, others including Lincoln's step mother dispute this claim. Sarah Bush Lincoln, interview with William H. Herndon, September 8, 1865," in Herndon's Informants) 107; Dirck, Lincoln \& Davis, 16; Oates,14.

650 "Sarah Bush Lincoln, interview with William H. Herndon, September 8, 1865," in Herndon's Informants: Letters, Interviews and Statements about Abraham Lincoln, ed. Douglas L. Wilson and Rodney O. Davis (Urbana: University of Illinois Press, 1998) (hereafter Herndon's Informants) 107; Brian R. Dirck, Lincoln \& Davis, Imagining America, 1809-1865, (Lawrence, Kansas: University Press of Kansas, 2001) 16; Oates, 14.

${ }^{651}$ Lincoln Autobiography, 7; A.L. to John D. Johnston, Springfield, January 12, 1851, Speeches and Writings, 82-3; Hanchett, 12-14.

${ }^{652}$ Another source of estrangement between father and son was the fact that Lincoln was often absent, riding the circuit, while Robert was growing up and so never had the opportunity to build a relationship with him until it was almost too late. A.L. to Mary Todd Lincoln, Exeter, Hew Hampshire, March 4, 1860, $\underline{\text { Speeches and }}$ Writings, 252; Oates, 105, 188.
} 
two youngest children, William Wallace and Thomas 'Tad,” Lincoln formed a remarkably close bond. It is worth noting that unlike Robert, who was sternly disciplined, Willie and Tad were never subjected to any sort of parental restraint. ${ }^{653}$

Lincoln also had direct experience with the code duello. The specific incident occurred in September, 1842, and involved several letters that Lincoln wrote directed at the Democratic State Auditor, James Shields. The episode began in February 1842, when the Illinois State Bank declared bankruptcy and Shields, as State Auditor, refused to accept the defunct bank's notes in payment for taxes. From a legal standpoint, Shields made the correct decision but it was very unpopular with the public. Lincoln and his fellow Whigs decided to exploit the unpopularity of the decision for their own political advantage and they attacked not only Shields but the entire Democratic Administration. ${ }^{654}$

Lincoln attacked Shields in a series of insulting letters to the editor of the Sangamo Journal. He was assisted in this by Mary Todd and one of her friends. Although written under assumed names, Shields found out who wrote the letters and on September 17, 1842, demanded that Lincoln retract the statements. (In order to protect the women, Lincoln claimed that he had written all of the letters.) Lincoln, although he was "wholly opposed to duelling" refused to back down. That brought a challenge to a duel from Shields. Lincoln, as the challenged party, had the

${ }^{653}$ Unfortunately it is almost impossible to gauge what influence may have had on his son's character development and their ideas of manhood, as only Robert, with whom his relationship was weakest, survived to adulthood. Oates, 104-105.

${ }^{654}$ Lincoln Autobiography, 46. 
choice of weapons. He chose broadswords and a date was set. Since dueling was illegal in Illinois, the antagonists agreed to meet in Missouri. ${ }^{655}$

Luckily a relative of Mary Todd, John J. Hardin, and another man, intervened to stop the encounter before the two came to blows. While the episode ended without bloodshed neither party had done much to cover themselves with glory. Certainly it was not Lincoln's finest hour. Although his actions in protecting the women's identities by accepting responsibility for the letters were entirely in keeping with the ideals of chivalry, the fact that he had written them anonymously certainly fell short of the masculine ideal of political candor. And to 'weasel out' of the encounter as Lincoln did was anything but chivalrous. Lincoln himself seemed to realize this. He never wrote another anonymous letter and he and Mary, to the end of their days, never spoke of the episode again. ${ }^{656}$

At this point it is perhaps appropriate to discuss Lincoln's political philosophy and it's relationship to masculinity. Lincoln believed in the labor theory of value. It was labor that gave things value, without labor capital was useless. Hard work and labor were the key to success. Everyone, regardless of how poor they were, could achieve success if they were willing to work hard. ${ }^{657}$ This basic idea formed the entire framework of Lincoln's political philosophy. It dictated his support for expansion. The western territories, which contained vast tracts of free or

${ }^{655}$ Lincoln Autobiography, 46-48; "Letter from the Lost Townships," Complete Works vol. 1, 221-231; James Shields to A.L., Esq., Tremont, September 17, 1842: A.L. to James A. Shields, Esq., Tremont, September 17, 1842; James A. Shields to A.L. Esq., Tremont September 17, 1842, all in Complete Works, vol. 1, 232-235;

"Memorandum of Instructions to E.H. Merryman, Lincoln's Second," September 18, 1842; Complete Works, vol. 1, 236-238.

\footnotetext{
${ }^{656}$ Lincoln Autobiography, 48-49; Williams, Judging Lincoln, 24..

${ }^{657}$ Foner, Free Soil, 9-11.
} 
at least cheap land, provided a place of economic opportunity, a chance to strike out on one's own. He also favored internal improvements, which by improving the 'infrastructure' also provided economic opportunity, along with the Whig Party which seemed to represent those values much better than their opponents, the Democrats. ${ }^{658}$ It also dictated his opposition to slavery, which he believed degraded labor by removing the hope for advancement and thereby reduced those who labored to a permanent subordinate state. ${ }^{659}$

But Lincoln was not an abolitionist. He thought that the abolitionists were too fanatical and that abolitionism itself was a volatile issue that was in large part responsible for the "hyper emotionalism" that had crept into national politics. Lincoln believed that this "hyper emotionalism" was responsible for the increasing frequency of violence, such as the November, 1837, incident in which a mob in Alton, Illinois, had killed abolitionist editor Elijah P. Lovejoy. ${ }^{660}$ For Lincoln the only practical solution, and certainly the only politically feasible solution, was to stop the slavery's spread into the territory. Lincoln, like many nineteenthcentury Americans, viewed slavery as an institution that would die if it was confined to those areas where it already existed. Beyond that Lincoln also believed that the western territories should be reserved for settlement by white homesteaders. ${ }^{661}$

${ }^{658}$ Donald, Lincoln, 59 \& 109.

${ }^{659}$ A.L. to the Editor of the Sangamo Journal, June 13, 1836, Speeches and Writings 7-8; Abraham Lincoln and Dan Stone (Representatives from the county of Sangamon), "Protest in the Illinois Legislature on Slavery," March 3, 1837, 9-10, "Eulogy on Henry Clay," Springfield, July 6, 1852, 88-89, all in Speeches and Writings.

${ }^{660}$ Abraham Lincoln, “The Perpetuation of our Political Institutions, (Address to the Young Men's Lyceum of Springfield, Illinois)” January 37, 1838, Speeches and Writings, 15, 20-21.

${ }^{661}$ Abraham Lincoln, "Speech at Edwardsville, Ill., September 11, 1858, 161; "Sixth Lincoln-Douglas Debate," Quincy, Illinois, October 13, 1858, 184, "Seventh Lincoln-Douglas Debate,” Alton, Ill., October 15, 1858, 194; "Speech at Chicago, Ill.," March 1, 1859, 214, all in Speeches and Writings. 
Like nearly everything else about him, Lincoln's advocacy of free-soil principles was based upon his own experience and a sense of what worked and what did not work, but it was also heavily influenced by antebellum masculinity. Given the close association between economic success and masculinity in the minds of nineteenth-century Americans, the Free Soil movement and its ideological successor the Republican Party, with its emphasis upon social mobility, the dignity of labor, entrepreneurial spirit, economic development, and its criticisms of southern society, was a political movement that seemed tailor-made to appeal to individuals, such as those living in the Old Northwest, grounded in an image of manhood based on aggression, economic success, self-reliance, and rugged individuals. ${ }^{662}$

Free Soil advocates argued that America was a land of almost boundless economic opportunity. They frequently cited Lincoln's own rise from total obscurity to professional success and national political prominence as evidence of the truth of the Free Soil gospel that anyone, if they worked hard enough and were talented enough, could rise as far as they desired. The myth of the self-made man, to them, was no myth; it was a very real possibility. ${ }^{663}$ Slave labor, in contrast, both degraded labor and lowered wages for free laborers who had to compete against unpaid slaves. Furthermore, Southern obstruction of Federal economic development legislation threatened to not only undermine northern males' economic freedom, but also their status as heads-of-households and chief breadwinners. This endangered northern males' paternalistic control over their wives and children as well as their status as citizens. Thus, in

\footnotetext{
${ }^{662}$ Foner, Free Soil, 9, 11-12, 15; Berlin \& Gutman, 1195.

${ }^{663}$ Leverenz, 4; Breen \& Hall, "Provincial Imagination,” 1431; Foner, Free Soil, 9-11,16, 33-34.
} 
eliminating economic opportunities in this way, southerners not only denied laboring men of the North the opportunity for self-improvement but also served to symbolically unsex them. ${ }^{664}$

These Free Soil tenets of economic development and the dignity of labor became the guiding principles of Lincoln's political career and helped propel him into the national political spotlight beginning in August, 1846, when Lincoln was elected to Congress by a wide majority. ${ }^{665}$ Although the Mexican War was pretty much over by the time Lincoln began to serve, the Whigs, who had condemned the conflict as an illegal land-grab, now attacked President James K. Polk for having "unnecessarily and unconstitutionally" begun the war. Lincoln joined in his party's attacks by introducing a set of resolutions that demanded to know "whether the particular spot of soil on which the blood of our citizens was so shed, was, or was not, our own soil." In a January, 1848, speech Lincoln accused Polk of having abused his presidential powers. ${ }^{666}$

I more than suspect already, that he is deeply conscious of being in the wrong-that he feels that blood of this war, like the blood of Abel, is crying to Heaven against him. That originally having some strong motive-what, I will not stop now to give my opinion concerning-to involve the two countries in a war, and trusting to escape scrutiny, by fixing the public gaze upon the exceeding brightness of military glory-that attractive rainbow, that rises in showers of blood-that serpent's eye, that charms to destroy-he

${ }^{664}$ Cott, "Marriage," 1452-1453; Berthoff, "Peasants and Artisans," 582, 585; Berlin and Gutman, 11761177.

${ }^{665}$ A.L. to Robert Boal, Springfield, January 7, 1846, 51-2, A.L to the Voters of Seventh Congressional District, July 31, 1846, 54-55, both in Speeches and Writings; A.L. to Henry E. Dummer, Springfield, Illinois, November 18, 1845, in Uncollected Letters of Abraham Lincoln, Collected by Gilbert A. Tracy) (Boston: Houghton Mifflin, 1917) (hereafter Uncollected Letters), 14-15; A.L. to B.F. James, December 6, 1845, Springfield, in Uncollected Letters, 16; A.L. to B.F. James, February 9, 1846, Uncollected Letters, 18-20.

${ }^{666}$ A.L. to William H. Herndon, Washington, February, 1, 1848, 65-66, A.L. to Herndon, Washington, February 15, 1848, 67-68, Abraham Lincoln, “'Spot' Resolutions in the U.S. House of Representatives," December 22, 1847, 57-59, Lincoln, "Speech in the U.S. House of Representatives on the War with Mexico," January, 12, 1848, 60-65 all in, Speeches and Writings; Lincoln Autobiography, 54-57, 60-62. 
plunged into it, and has swept, on and on, till, disappointed in his calculation of the ease with which Mexico might be subdued. ${ }^{67}$

Lincoln had hoped that the speech would attract national attention but it was, for the most part, ignored both by Congress and by the president. Lincoln left office in March, 1849, largely disappointed with his tenure in Congress. ${ }^{668}$ Lincoln spent the next few years tending to his law practice and raising his sons. ${ }^{669}$ He was finally driven back to politics by the passage in 1854 of the Kansas-Nebraska Act which was authored by his old political rival, Senator Stephen A. Douglas. In an October 16, 1854, speech Lincoln explained the reasons for his opposition to the Kansas-Nebraska Act, which he condemned as a "monstrous injustice."

I hate it because it deprives our republican example of its just influence in the worldenables the enemies of free institutions, with plausibility, to taunt us as hypocrites-causes the real friends of freedom to doubt our sincerity, and especially because it forces so many really good men amongst ourselves into an open war with the very fundamental principles of civil liberty--criticizing the Declaration of Independence, and insisting that there is no right principle of action but self-interest. ${ }^{671}$

When a coalition composed mostly of antislavery Whigs and Democrats decided to form a new political party, the Republicans, to oppose the Kansas-Nebraska Act, Lincoln became one

\footnotetext{
${ }^{667}$ Abraham Lincoln, "Speech in the U.S. House of Representatives on the War with Mexico," Washington, D.C., January, 12, 1848, Speeches and Writings 62-3 .

${ }^{668}$ Lincoln Autobiography, 66-67, 84; Nicolay and Hay, vol. 1, $\underline{\text { History, }} 290$.

${ }^{669}$ Lincoln became one of the foremost railroad lawyers in Illinois. Judge David Davis of the Eighth Judicial District had so much confidence in Lincoln's abilities that, when called away by family illness or some other emergency, Davis often designated Lincoln to preside in his stead. A.L. to William B. Preston, Springfield, May 16, 1849, 79, A.L. to Elisha Embree, Springfield, May 25, 1849, 80, both in Speeches and Writings,; Lincoln Autobiography, 82-83, 84-86, 88; A.L. to Thomas Ewing, Secretary of the Interior, Washington, D.C., June 22, 1849, Uncollected Letters, 39; A.L. to John M. Clayton, Secretary of State, Springfield, Illinois, July 28, 1849, Uncollected Letters, 39; A.L. to W. B. Warren and others, April 7, 1849, vol. 2 Complete Works 110-112; A.L. to D.M. Irwin, Springfield, Ill., (undated), Uncollected Letters; Hanchett, 42.

${ }^{670}$ A.L., "Speech on the Kansas-Nebraska Act," Peoria, Illinois, October 16, 1854, Speeches and Writings, 93-99; Hanchett, 43-44.

${ }^{671}$ A.L., "Speech on the Kansas-Nebraska Act," Speeches and Writings, 94.
} 
of its leaders in Illinois. ${ }^{672}$ During the 1856 presidential election, Lincoln campaigned hard for the Republicans' first candidate, John C. Fremont. ${ }^{673}$

When the Supreme Court, in January, 1857, handed down the Dred Scott case Lincoln, like many Northerners, was outraged. ${ }^{674}$ His outrage over Dred Scott led Lincoln to challenge Stephen Douglas for the U.S. Senate. This set the stage for the famous Lincoln-Douglas debates. The debates were the highlight of the campaign and allowed Lincoln and Douglas to express their views not only on Dred Scott but on many of the issues then dividing North and South. ${ }^{675}$ Indeed the debates provided an ideal forum for Lincoln who in his long years of practicing law had honed his debating techniques to a fine art. One admirer described Lincoln's rhetorical prowess and skill at formulating an argument in language that could also have been applied to his performance in the debates with Douglas:

his law arguments were master-pieces of logical reasoning. There was no refined artificiality in his forensic efforts. They all bore the stamp of masculine common sense;

${ }^{672}$ McPherson, Battle Cry, 129-130; Potter, Crisis, 247-250..

${ }^{673}$ At the Republican convention, which met in Philadelphia from June 17-19, the Illinois delegation arranged to have Lincoln's name placed into nomination for Vice President. A.L. to Lyman Trumbull, Springfield, June 7, 1856, 106-107, A.L. to Lyman Trumbull, Springfield, August 11, 1856, 107, A.L., "Speech at Kalamazoo, Michigan, 108-114, A.L., "Speech at Republican Banquet in Chicago, Illinois, December 10, 1856, 115-16, all in

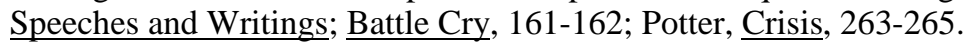

${ }^{674}$ McPherson, Battle Cry, 170, 175-177; Potter, Crisis, 267-268, 279-283; A.L., "Speech on the Dred Scott Decision at Springfield, Illinois," June 26, 1857, Speeches and Writings, 117-122.

${ }^{675}$ A.L., "'House Divided' Speech at Springfield, Illinois,” June 16, 1858, 131-19, A.L., "Speech at Chicago, Illinois," July 10, 1858, 140-148, "First Lincoln-Douglas Debate," Ottawa, Illinois, August 21, 1858, 149-153, "Second Lincoln-Douglas Debate," Freeport, Illinois, August 27, 1858, 154-159, Lincoln, "Speech at Edwardsville, Illinois," September 11, 1858, 159-163, “Third Lincoln-Douglas Debate,” Jonesboro, Illinois, September 15, 1858, 164-172, "Fourth Lincoln-Douglas Debate," Charleston, Illinois, September 18, 1858, 173-175, "Fifth LincolnDouglas Debate," Galesburg, Illinois, October 7, 1858, 177-183, "Sixth Lincoln-Douglas Debate, Quincy, Illinois, October 13, 1858, 184-89, Seventh Lincoln-Douglas Debate," Alton, Illinois, October 15, 1858,190-196, A.L. to Norman B. Judd," October 20, 1858, 197; A.L. "Speech at Springfield, Illinois, October 30, 1858, 198-99, all in Speeches and Writings; Donald, Lincoln, 202, 205-6, 208-212, 214, 215, 220-225, passim Hanchett, 44-5. 
and he had a natural easy mode of illustration, that made the most abstruse subjects appear plain. ${ }^{676}$

Although they spoke before mixed audiences of men and women, both Lincoln and Douglas knew who their true constituency was. Hence the language that they used during the debates was, to a considerable degree, intended to appeal to white, male, sensibilities. The following passage, from the first debate at Ottawa, Illinois, clearly displayed Lincoln's desire to appeal, not only to the Northern mythology of economic opportunity and the self-made man, but to Northern racial prejudices as well:

I agree with Judge Douglas he (i.e. a black man) is not my equal in many respects-certainly not in color, perhaps not in moral or intellectual endowment. But in the right to eat the bread, without leave of anybody else, which his own hand earns, he is my equal and the equal of Judge Douglas, and the equal of every living man. ${ }^{677}$

In the fourth debate, at Charleston, Illinois, Lincoln carried this line of argument even further by blatantly appealing both to antebellum sexual mores and to racial fears over miscegenation:

I do not understand that because I do not want a negro woman for a slave I must necessarily want her for a wife. (Cheers and laughter) My understanding is that I can just let her alone. ... .I have never had the least apprehension that I or my friends would marry negroes if there was no law to keep them from it, (laughter) but as Judge Douglas and his friends seem to be in great apprehension that they might, if there were no law to keep them from it, (roars of laughter) I give him the most solemn pledge that I will to the very last stand by the law of the State, which forbids the marrying of white people with negroes (Continued laughter and applause). ${ }^{678}$

\footnotetext{
${ }^{676}$ Abraham Lincoln, David W. Bartlett, Life and Public Services of Hon. Abraham Lincoln, with a Portrait on Steel, To which is Added a Biographical Sketch of Hon. Hannibal Hamlin, (New York: H. Dayton, 1860) 25, accessed through Illinois Historical Digitization Projects, Northern Illinois University Libraries, Copyright 2001. \{http://lincoln.lib.niu.edu/cgi-bin/contextualize_?p.2475./lib35/artfl!/databases/sources/IMA.

${ }^{677}$ A.L., "First Lincoln-Douglas Debate," Ottawa, Illinois, August 21, 1858, in Speeches and Writings 149.

${ }^{678}$ A.L., from "Fourth Lincoln-Douglas Debate," Charleston, Illinois, September 18, 1858, in $\underline{\text { Speeches and }}$ Writings 173, 174.
} 
Later that same year, Lincoln seemed to turn those same racial fears on their head and to argue that it was southerners who were the true predatory race and blacks who were the innocent victims in need of protection, responding to the arguments of southern clergymen that slavery benefitted slaves: "Nonsense! Wolves devouring lambs, not because it is good for their own greedy maws, but because it is good for the lambs!!!"679

Although Douglas won the senatorial election, Lincoln became a national political figure and gained a great deal of momentum that carried him into the White House two years later. ${ }^{680}$ Lincoln's election as president in 1860 set off a wave of secession across the South and by the time Lincoln left Springfield for Washington on February 11, 1861, seven deep-south states had already left the Union. ${ }^{681}$

Before he took office, however, Lincoln had one more humiliation to endure. While on his way to Washington for his inauguration Lincoln was informed of reports of a conspiracy to assassinate him in Baltimore. ${ }^{682}$ Against his better judgement Lincoln was convinced by General Winfield Scott and Secretary of State-designate William H. Seward to depart early from Harrisburg and pass through Baltimore in the middle of the night in order to avoid any potential threat. $^{683}$ This proved to be a critical error. The press ridiculed Lincoln's secret arrival in

\footnotetext{
${ }^{679}$ A.L., "On Pro-slavery Theology,” in Speeches and Writings; 176.

${ }^{680}$ Donald, Lincoln, 202, 205-6, 208-212, 214, 215, 220-225, passim Hanchett, 44-5.

${ }^{681}$ A.L. to Samuel Galloway, Chicago, March 24, 1860, 261-262, A.L. to Lyman Trumbull, Springfield,
} April 29, 1860, 262-263, A.L. to George Ashmun, Springfield, May 23, 1860, 263, all in Speeches and Writings; Donald, Lincoln, 236-41, 244-246, 247-250; Hanchett, 45-47; Hanchett, 52-3; Long, 32, 36.

\footnotetext{
${ }^{682}$ Hanchett, 53; Long, 36, 37, 39, 40-1.

${ }^{683}$ Hanchett, 55-6; Davis, 305, 307; Long, 36, 37, 39, 40-1
} 
Washington, and alleged, perhaps correctly that there had been no plot against him. Democrats, by portraying Lincoln as a coward and a fool who was too frightened to confront the alleged assassins, seriously called into question Lincoln's courage and his manhood. ${ }^{684}$ Thus as he prepared to take the oath as President on March 4, 1861, northerners and southerners alike must have wondered what sort of president, and what sort of man, Lincoln was and whether they had another weak president-in the mold of James Buchanan--on their hands. ${ }^{685}$

${ }^{684}$ Hanchett, 56.

${ }^{685}$ Hanchett, 56-7; Long, 41, 43-5: Richard Current, Lincoln and the First Shot, 34-5; Nicolay and Hay, vol. 3 History (New York: Century, Col, 1890), 369-71. 


\section{CHAPTER 8}

\section{THE SUMTER CRISIS}

Sad as have been the consequences of the war which followed secession--disastrous in its moral, material, and political relations--still we have good cause to feel proud that the course of the Southern States has left no blot nor stain upon the honor and chivalry of her people.

-Jefferson Davis. ${ }^{686}$

In assessing the influence of antebellum masculinity on the Sumter Crisis of 1861, it is important to point out that the influence was both direct, through the persons of Presidents Lincoln and Davis and the degree to which they embraced antebellum ideas of masculinity, and indirect through societal norms and the pressures that external forces brought to bear upon these individuals. The events of the Sumter Crisis are well known and need not be restated in detail, however in the interest of clarity and in order to place my analysis within its proper context, a brief recounting of the events is useful.

As he prepared to take the oath of office as President of the United States on March 4, 1861, Abraham Lincoln found himself confronted by a situation that must have seemed overwhelming. Weeks earlier, when he departed his Springfield, Illinois, home Lincoln told the crowd of well-wishers that he faced "a task before me greater than that which rested upon Washington." ${ }^{687}$ Those words came back to Lincoln with startling clarity. Seven states had already left the Union, created a government that they called the Confederate States of America,

${ }^{686}$ Jefferson Davis, The Rise and Fall of the Confederate Government, (New York: Thomas Yoseleff, 1958) 226.

${ }^{687}$ Abraham Lincoln, "Farewell Address at Springfield, Illinois," Speeches and Writings, 277 
selected, as president, Jefferson Davis, and seized federal governmental and military installations in the South. ${ }^{688}$

They lacked the means, however, to seize the two biggest prizes, Fort Pickens at Pensacola, Florida, and Fort Sumter at Charleston, South Carolina. ${ }^{689}$ While both forts were strategically and politically important, the fact that Fort Sumter guarded the harbor of Charleston, perhaps the most radically pro-secession city in the South, made it the focal point for both North and South. ${ }^{690}$ Commanded by Major Robert Anderson, Fort Sumter occupied a manmade island located at the narrowest point of Charleston Harbor. Begun in 1827, by 1860 it was still incomplete and mounted only fifteen serviceable guns. ${ }^{691}$

Surrounding Sumter was an impressive array of Confederate fortifications: to the west, Castle Pinckney; to the north, Fort Moultrie and a floating battery of four guns; south of Sumter,

688 "The Mouth of the Mississippi," Chicago Daily Tribune, December 18, 1860, in Perkins, Ii, 539-540; Also "Secession and Mississippi Navigation," Cincinnati Daily Gazette, January 14, 1861, "Obstructing the Mississippi," Milwaukee Daily Wisconsin, January 18, 1861; "The Mouth of the Mississippi," Cincinnati Daily Commercial, January 25, 1861; "Navigation of the Mississippi River," Burlington (Iowa) Daily Hawkeye, February 8, 1861; "Navigation of the Mississippi," Evansdale (Ind.) Daily Journal, February 12, 1861; "Navigation of the Mississippi," Cleveland Morning Leader, February 21, 1861; "Navigation of the Mississippi," Chicago Daily Tribune, February 25, 1861; "Controlling the Mississippi," Troy Daily Arena, February 28, 1861; "The Free Navigation of the Mississippi," Milwaukee Daily Sentinel, March 1, 1861; all in Perkins, II, 540-561, passim; Statement from J.A.P. Campbell of Mississippi,"; "Statement from Duncan F. Kenner of Louisiana”, both cited in

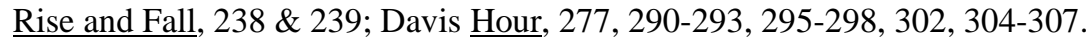

${ }^{689}$ Fort Pickens remained in Union hands throughout the War. Bvt. Lt. Col. J.H. Gilman, "With Slammer in Pensacola Harbor, in Battles and Leaders of the Civil War (hereafter BL), Volume one, Thomas Yoseloff Inc., 1956) 26.

${ }^{690}$ Roy Meredith, Storm over Sumter: The Opening Engagement of the Civil War (New York: Simon and Schuster, 1957) 14, 16, 18.

${ }^{691} \mathrm{By}$ the time of the bombardment Anderson's men had managed to increase that number to 48 guns and four mortars. J.G. Foster, Captain, Engineers, "Engineer Journal of the bombardment of Fort Sumter by Captain J.G. Foster, Corps of Engineers, U.S. Army," The War of the Rebellion: A Compilation of the Official Records of the Union and Confederate Armies, (Washington D.C.: Government Printing Office, 1880) (130 Volumes) Series I, Volume I (hereafter $\underline{\mathrm{O}-\mathrm{R}}), 18$; Meredith, 24-25. 
Fort Johnson and Cummings Point. Commanding the Southern batteries was Brigadier General P.G.T. Beauregard. ${ }^{692}$

Sumter was not the only issue that faced the two "nations." Perhaps the most troubling, after Sumter, was the potential impact of secession on the national economy. While some Northerners argued that separation might be economically beneficial, most saw it as a threat. ${ }^{693}$ First there was the economic value of the departed states themselves: According to a Cleveland Daily National Democrat editorial, for the year ending June, 1858, Southern cotton accounted for $\$ 131,386,661$ out of $\$ 293,758,279$ in total United States exports. ${ }^{694}$ Those figures were perhaps inflated, but there was no denying cotton's economic importance. And when the value of cotton was added to that of hemp, naval stores, sugar, rice, and tobacco produced in the South, not to mention the loss of federal revenue from southern imports, it quickly became apparent that secession would be an economic disaster. ${ }^{695}$

Even more important was the Mississippi River and especially New Orleans, which was the main exit port for the Old Northwest. Not only would secession bring about such disruptions in customs inspection, tariffs and the like, but the seceding states might, in order to force the

${ }^{692}$ Stephen D. Lee, Lieutenant General, CSA, “The First Step in the War,” BL, Vol. I, 81; Meredith, 26-28; in his journal of the bombardment, Captain J.G. Foster of the Corps of Engineers, estimated the total strength at 30 guns, 17 mortars. Foster, "Engineer Journal" $\underline{\mathrm{O}-\mathrm{R}}, 19$.

693 “The Effect of a Peaceable Separation on Trade," Cincinnati Daily Press, February 1, 1861, reprinted in Northern Editorials on Secession, 2 Vols. Howard Cecil Perkins, Ph.D. ed. (Gloucester Mass: Peter Smith, 1964 (hereafter Perkins) II, 586-9.

694 "Of What Use is the South to Us?” Cleveland Daily National Democrat, November 20, 1860, in Perkins, II, 562.

${ }^{695}$ Ibid., 563; also "Let Them Go!," Manchester (N.H.) Union Democrat, February 19, 1861, Perkins, II, 591-592; "What Shall Be Done for a Revenue?" New York Evening Post, March 12, 1861, Perkins, II, 598-601. 
North to recognize their independence, resort to economic blackmail and close the Mississippi to all Northern traffic. ${ }^{696}$ Railroad traffic might also be disrupted and northern firms would surely find it more difficult to do business in the South. ${ }^{697}$

But for the most part Fort Sumter remained the center of attention. Given the somewhat questionable circumstances under which Lincoln had come to office, he could ill afford to squander the little credibility he had by appearing weak and indecisive. Southerners had justified secession on the grounds that Lincoln's election represented an imminent threat to slavery and other southern institutions. ${ }^{698}$ Even Lincoln's strongest supporters had to view his election victory as a fluke. After all Lincoln had carried only $40 \%$ of the popular vote. ${ }^{699}$ Furthermore,

${ }^{696}$ One newspaper, the Cincinnati Daily Gazette even suggested that in order to prevent the "madcap disunionists" from disrupting "the free navigation of the Mississippi" it might be necessary to cause the river to flood New Orleans. "Secession and Mississippi Navigation," Cincinnati Daily Gazette, January 14, 1861, in Perkins, II, 543-547; also "The Mouth of the Mississippi," Chicago Daily Tribune, December 18, 1860; "The Mouth of the Mississippi," Buffalo Morning Express, December 24, 1860; "Louisiana and the Mississippi," New York Daily News, December 25, 1860; "Obstructing the Mississippi," Milwaukee Daily Wisconsin, January 18, 1861; "The Course of Western Commerce," Cincinnati Daily Commercial, February 20, 1861, all in Perkins II, 539-96.

697 “The Commercial Relations between the North and the South,” New York Times, December 7, 1860 , Perkins, II, 567; also "Value of the Union," Daily Chicago Times, December 10, 1860; "Payment of Southern Debts to the North," Boston Daily Atlas and Bee, December 3, 1860; "Southern Repudiation of Debts Due the North," Montpelier Daily Green Mountain Freeman, May 17, 1861, all in Perkins, II, 564-575 \& 605-606.

698 "Declaration of the Immediate Causes Which Induce and Justify the Secession of South Carolina From the Federal Union," December 24, 1860, Journal of the Convention of the People of South Carolina Held in 1860, 1861, and 1862; Together with the Ordinances, Reports, Resolutions, etc, (Columbia, South Carolina: R. W. Gibbes, Printer to the Convention, 1862) 461-466. Furman University Department of History, Online Primary Source Collection (19 ${ }^{\text {th }}$ Century, U.S.) <http://alpha.furman.edu/ benson/docs/ddemplatt.htm $\geq$.

699 "National Democratic (Douglas) Platform, Adopted at Charleston and Baltimore, 1860," <http://alpha.furman.educ/ benson/docs/ddemplat.htm>;"National Democratic (Breckinridge) Platform, Adopted at Charleston and Richmond, 1860" http://alpha.furman.edu/ benson/docs/bedemplat.htm>. "Constitutional Union (Bell-Everett) Platform, adopted at Baltimore, 1860" (http://alpha.furman.educ/ benson/docs/conuplat.htm); all from The Tribune Almanac for the Years 1838 to 1868, inclusive, comprehending the Politicians Register and the Whig Almanac (New York: Published by the New York Tribune, 1868, Furman University Department of History, Online Primary Source Collection (19 ${ }^{\text {th }}$ Century U.S.); McPherson, Battle Cry, 58, 62, 122-123, 213-216; Davis, Hour, 287-290-293, 297. 
Lincoln's election, which came barely thirteen months after John Brown's raid, seemed to confirm Southern fears of an abolitionist plot to deprive them of their slaves and to subject them to the twin horrors of radicalism and miscegenation. ${ }^{700}$

As mentioned above, Lincoln had already committed a serious error in judgement by allowing himself to be talked into departing Harrisburg, Pennsylvania ahead of schedule and slipping through Baltimore on the night of February 22-23 while disguised in a "scotch cap" and shawl. While the assassination threats may have been real, the episode provided ample fodder for Lincoln's critics to accuse him of cowardice. At the very least he was made to look foolish. ${ }^{701}$ Meanwhile conditions at Sumter were deteriorating quickly. The garrison was running short of supplies and unless they received fresh provisions Sumter would have to be evacuated. Lincoln faced a serious dilemma. While the fort itself was of questionable military value, Lincoln could not simply let it go. Should he do so, both his commitment to maintaining the Union and his presidency would lose all credibility; even the Republican Party would abandon him. Furthermore if he let Sumter go without a fight the rebels would only be encouraged to make further demands, first for Pickens, then for other forts in the South. Where would it end,

${ }^{700}$ Davis, Hour, 290; Meredith, 46-47.

${ }^{701}$ While Lincoln tried to recover his dignity, others were working feverishly to try to avoid or at least postpone the impending clash. Several compromises were proposed in the early weeks of 1861, none of them particularly feasible. The most promising, or at least the most well promoted, consisted of a set of proposals known collectively as the "Crittenden Compromise" after its sponsor Senator John J. Crittenden of Kentucky. The Crittenden Compromise was formulated by the Senate "Committee of Thirteen" whose members included Jefferson Davis Despite impressive lobbying efforts by its namesake, the Crittenden Compromise, like all the others, failed, largely because of Lincoln's objections that it amounted to a surrender to Southern threats. One final attempt, the socalled Washington Peace Conference chaired by former President John Tyler also ended in failure. Current, 34-35; Davis, Hour, 288, 290, 305 \& 307; Maury Klein, Days of Defiance: Sumter, Secession and the Coming of the Civil War, (New York: Alfred A. Knopf, 1997) 261-267, passim; Charles P. Stone, Brigadier-General, U.S.V. "Washington on the Eve of the War," BL, 23-24; Long, 41; Current, 34-35. 
with recognition of the Confederacy, perhaps even the surrender of Washington D.C. itself? ${ }^{702}$

But at the same time Lincoln could not afford to alienate the Border States by taking any action which might make him look like the aggressor. Indeed to appear too aggressive would play into the hands of the secessionists who had justified their actions on the basis of alleged Republican tyranny. On the other hand, restraint could not only keep the borders states in, "but might also win back the seceded states as well." Also in the event of a military confrontation, should the South be successful it would greatly invigorate their national self-confidence. ${ }^{703}$

Jefferson Davis faced a similar dilemma. Like Lincoln he did not want to be painted as the aggressor. On the other hand, being the leader of what was purported to be an independent nation, he could not afford to allow the Union to retain Sumter or Pickens. To do so would be to allow a foreign power (i.e. the United States) to occupy two of their most important ports of entry. The question was, how to get the Yankees out without resorting to violence?

In his inaugural address Lincoln struck a conciliatory tone, assuring Southerners that they had nothing to fear from a Republican administration. He had no intention, and no lawful right, to interfere with slavery where it already existed. Both the Southern states and their citizens retained all their rights and legal safeguards guaranteed to them under the Constitution. ${ }^{704}$ But he also left no room for doubt that he intended to be President of the entire United States. While he acknowledged that "the people have a constitutional right to amend (the government)--or a revolutionary right to dismember or overthrow it," still the Union was perpetual and secession

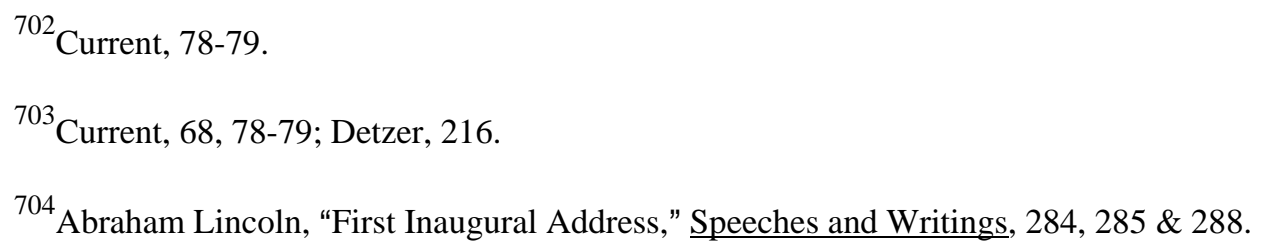


illegal. $^{705}$

On his first full day as president, March, 5, 1861, Lincoln went to his office where he found a stack of messages from Major Anderson that awaited his attention. ${ }^{706}$ They contained the alarming news that Anderson would probably run out of supplies before a relief expedition could reach him and that to mount such an expedition would require "not less than 20,000" men. Outgoing War Secretary Joseph Holt told Lincoln that the War Department was incapable of undertaking such an expedition. ${ }^{707}$

Uncertain of what to do, Lincoln turned to his top military advisor, General Winfield Scott, General of the Army and hero of the Mexican War, for advice. Now seventy-five years old and past his prime, Scott's opinion still carried a lot of weight. Scott agreed with Holt's assessment that a relief expedition was impossible. Scott told Lincoln that it might have been possible to resupply the fort three months earlier, but by now it was too late. There was even worse news: not only was the surrender of Fort Sumter "inevitable" but that of Fort Pickens as well. Unwilling to give up so easily Lincoln ordered Scott to more thoroughly investigate the situation at Sumter. ${ }^{708}$ In addition to General Scott, Lincoln also sought the advice of his cabinet. Lincoln held several cabinet meetings during his first week in office. The main topic of

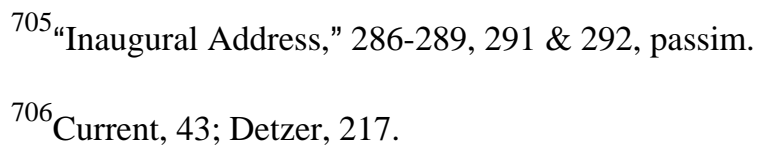

${ }^{707}$ Holt had agreed to stay on until Lincoln's Secretary of War, Simon Cameron, arrived in Washington. Diary of Gideon Welles, Secretary of the Navy Under Lincoln and Johnson (In three Volumes) Edited by Howard K. Beale (New York: W.W. Norton \& Company, 1960) Vol. 1, 3-6 (hereafter Welles); The Diary of Edward Bates, 1859-1866 Edited by Howard K. Beale (Washington D.C.: U.S. Government Printing Office, 1933) (hereafter Bates) 177.

${ }^{708}$ Welles, 3-5; Klein, 320. 
discussion was always Sumter and whether the fort should be abandoned or re-supplied.

Unfortunately for Lincoln, most of the cabinet seemed to agree with Scott's opinion that the fort should be abandoned. $^{709}$

Throughout the early part of March, while Lincoln struggled to find an acceptable solution to the Sumter question, rumors began to circulate that he intended to give up Sumter. ${ }^{710}$ These rumors, fueled by Scott's evacuation proposal, raised concerns among Senate Republicans that Lincoln might cave in to Southern pressure. The Maryland Unionist Frank Blair visited Lincoln on March 12 and bitterly protested that any surrender of Sumter would be a "surrender of the Union."711 The next day Postmaster General Montgomery Blair came to see Lincoln with what he thought might be a way out of the dilemma. Blair brought with him his brother-in-law and naval officer Gustavus Vasa Fox. Unlike Scott who thought that it would take six-to-eight months to launch a relief expedition, Fox thought it could be accomplished "in a matter of days." ${ }^{712}$ Despite some concerns among army officers that Fox's plan was unworkable, if nothing else the scheme served to convince Lincoln that a relief expedition to Sumter was at least feasible. $^{713}$

${ }^{709}$ Detzer, 214-220, passim; Klein, 323-325.

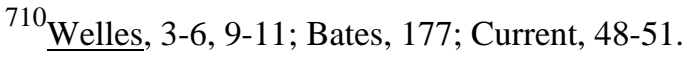

${ }^{711} \underline{\text { Welles, }}$ 13-14; Current, 22-23.

${ }^{712}$ Rather than try to reach Sumter with light unarmed craft that could pass over the sandbars and manmade obstructions at the harbor entrance, as Scott advocated and for which the Confederates would be prepared, Fox called for a more "head-on" approach. Utilizing a kind of convoy system, Fox would load men and supplies onto a large transport and two rented tug-boats which would be escorted by two armed warships. If the flotilla met with resistance the two warships, aided by Sumter's guns, would drive into the harbor and relieve the fort. Welles, 15; Current, 57, 60-61.

${ }^{713}$ Current, 62, 63, 99; Klein, 331-333; Detzer, 226-227. 
With that in mind Lincoln, on March 18, called a cabinet meeting to discuss the following question: "Assuming it to be possible to now provision Fort-Sumpter (sic), under all the circumstances, is it wise to attempt it?"714 Four members of the cabinet, Secretary of State William Seward, Secretary of the Navy Gideon Welles, Attorney General Edward Bates, and Secretary of War Simon Cameron, were firmly against the idea. Only Blair and Treasury Secretary Salmon Chase were solidly in favor and Secretary of the Interior Caleb B. Smith was undecided. $^{715}$

Frustrated, Lincoln again turned to Gustavus Fox for answers and sent him, on March 21, to Charleston to meet with Major Anderson and with Confederate officials. When Fox returned from Charleston on March 25, he was more convinced than ever that Sumter could be relieved by sea. ${ }^{716}$ Later that same day Lincoln sent two more emissaries to Charleston, Stephen S. Hurlbut and Ward H. Lamon, to gain a sense of what the public mood was. Both concluded that "no attachment to the Union" existed in South Carolina. ${ }^{717}$ On March 28, 1861, after hearing from Hurlbut and Lamon, Lincoln finally reached a resolution. At the cabinet meeting that day Lincoln informed the cabinet of his decision to resupply Sumter. ${ }^{718}$ With that Lincoln immediately ordered Cameron and Welles to begin putting together a relief expedition to Sumter, to depart no later than April 6, and dispatched Fox to New York to take charge of the

${ }^{714} \underline{\text { Bates, }} 178$.

${ }^{715}$ Bates, $178-179$.

${ }^{716}$ Welles, 15-16; Current, 73, 51.

${ }^{717}$ Current, 72-74, 98; Welles, 9.

718“"Memorandum of Different Plans for Reinforcing Fort Sumter: Inclosure B: General Scott's Memoranda for the Secretary of War," O-R., 201; Long, 51; Current, 77; Klein, 307-308. 
preparations for the expedition. $^{719}$

So far this chapter has been focused mainly on the Lincoln Administration and has said relatively little about Jefferson Davis and his government. The reason for this is that aside from making cabinet and other governmental appointments and overseeing military preparations, Davis had not been doing much, at least in reference to Sumter. This is not to say that Davis was completely idle, merely passive. This passivity was at least in part a matter of necessity. Davis's policy, as stated in his inaugural address, was to seek "peace and commerce with all nations" (including the United States) and to resort to war only in self-defense against "wanton aggression on the part of others."720

But as determined as Davis was "to have a peaceful separation," he was equally determined to capture Forts Sumter and Pickens by whatever means necessary, but preferably through negotiation. Having appointed a three person Peace Commission and given them authority to negotiate for the forts' surrender, there was little more for Davis to do but wait for

\footnotetext{
${ }^{719}$ On April 4, Lincoln, at Seward's suggestion, met with Virginia Unionist John B. Baldwin, a member of the Virginia convention that earlier in the day had rejected secession by a vote of two-to-one. The topic of discussion was of course Virginia's potential secession and how the Old Dominion might be kept in the Union. The meeting with Baldwin convinced Lincoln once and for all that Virginia was a lost cause. Later that afternoon, Lincoln ordered Fox to begin final preparations for the Sumter expedition. Lincoln met at least twice more with Virginia Unionists, each time with similarly futile results. Welles, 15; Lincoln to Simon Cameron, O.-R., Ser. I, Vol. 1, 226; Simon Cameron, Speeches and Writings, 295; John B. Jones, A Rebel War Clerk’s Diary, Edited by Earl Schenck Meers (New York: A.S. Barnes \& Company, 1961) 2; Negotiations-Not Legislation," Richmond Enquirer, December 18, 1860 in Southern Editorials on Secession, Edited by Dwight L. Dumon (New York: The Century Company, 1931) 345-346; George P. Smith to John Hay, January 9, 1863 and From John Minor Botts to Abraham Lincoln, April 17, 1861, Lincoln Papers, (Memory); Gideon Welles to Capt. Samuel Mercer, April 5, 1861, O-R, 241; Simon Cameron, Speeches and Writings, 295; G.W. Snyder, First Lieutenant of Engineers to Major Robert Anderson, April 4, 1861, O-R, 241-242; Simon Cameron to Captain Gustavus V. Fox, April 4, 1861, O-R, 225-226;. Current, 31-35, passim, 76, 81, 94-96, 100; Bates, 151.

${ }^{720}$ Jefferson Davis, "Inaugural Address," The Messages and Papers of Jefferson Davis and the Confederacy, including diplomatic correspondence, (hereafter MP) edited and compiled by James P. Richardson, Vol. I (New York: Chelsea House-Robert Hector Publishers, 1966), 33 \& 36; Rise and Fall, 243.
} 
events to play themselves out. ${ }^{721}$ With the Sumter issue thus taken out of his hands, at least for the moment, Davis and the Confederate Congress instead focused upon the task of putting their new government into operation, establishing various bureaus and departments, appointing diplomatic representatives and drafting and adopting a permanent constitution. ${ }^{722}$

But, as pressing as these administrative matters were, Davis's first priority was with military defense. ${ }^{723}$ Within a week of taking office, Davis began to prepare his forces for a possible conflict, and had been "making inquiries" as to the state of affairs at Charleston. ${ }^{724}$ On March 1, Davis appointed General Beauregard to command of the forces at Charleston and General Braxton Bragg to command of those at Pensacola, Florida. ${ }^{725}$

On March 18, Davis wrote to South Carolina Governor Francis Pickens and, after expressing the opinion that he doubted that Lincoln would voluntarily surrender Sumter without a fight, inquired about the state of the Charleston coastal defenses. ${ }^{726}$ Davis also had Secretary of War Leroy Walker send a similar warning to Beauregard, telling the General to give no credence to press rumors about an imminent settlement. Instead he warned: "Do not slacken for a moment your energies" The Union government was simply stalling for time. Such being the case it was to the Confederacy's advantage to play along for now in order that they might "make

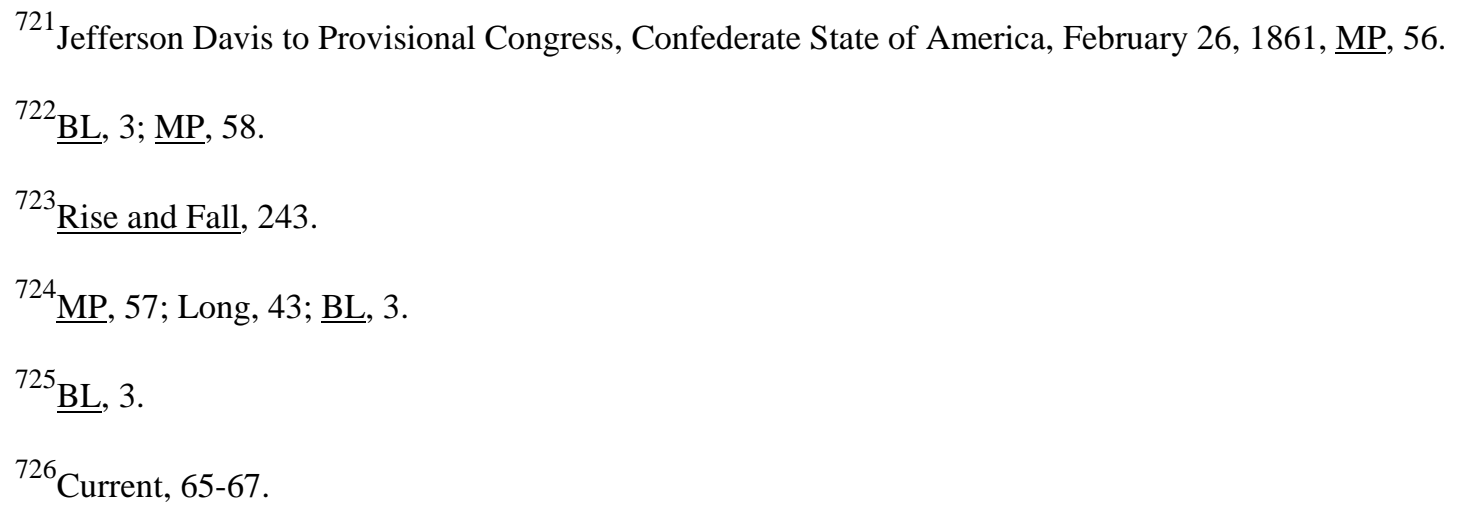


all the necessary arrangements for the public defense, and the solidifying of their Government."727

Beauregard largely supported Davis's strategy of waiting but as he wisely pointed out, in his March 27 message, the Confederates should delay in removing Anderson no longer than was absolutely necessary to complete their own military preparations. ${ }^{728}$

Meanwhile, on the morning of April 7, Anderson received a letter from Lincoln informing him that an expedition was on its way to reinforce the fort and that he should "hold out, if possible, till the arrival of the expedition." But if a surrender became necessary: "you are authorized to make it."729 That same day Davis received confusing reports from his peace commissioners that Lincoln was meeting with military officials for unknown purposes. The Commissioners had been unable to learn the "object of the movement" but all agreed that there were huge military preparations underway. The Yankees, being underhanded as well as cowardly, would probably give no warning until the expedition was actually underway. Until then vigilance ought to be the order of the day: "Watch at all points."730

Thus warned, Davis immediately wired Beauregard and instructed him not to expect Sumter to be given up voluntarily. Beauregard was to take no offensive action but to put himself "on a war footing,"await further orders, and in the meantime allow Anderson to make no further

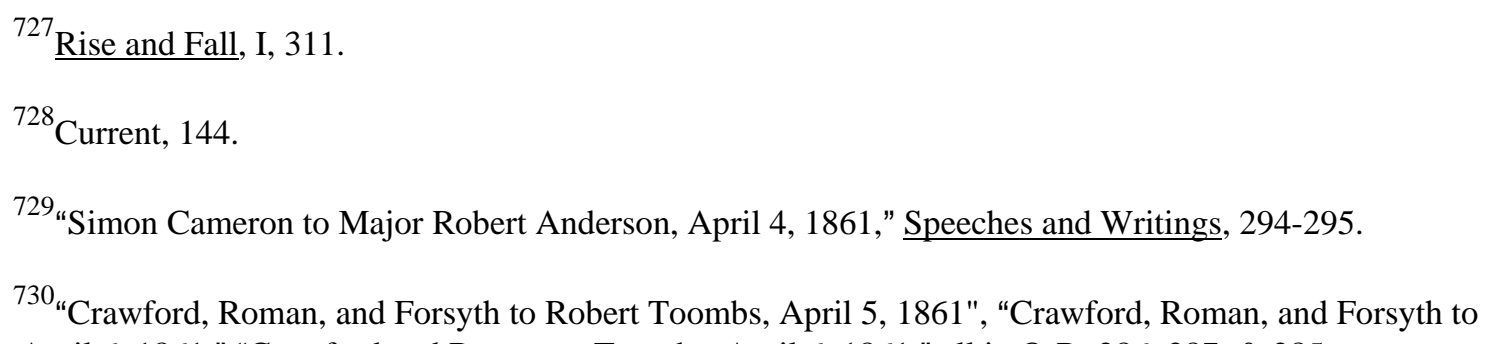
Toombs, April 6, 1861," "Crawford and Roman to Toombs, April 6, 1861," all in O-R; 286, 287, \& 285. 
food purchases from Charleston. ${ }^{731}$ After learning of Seward's refusal to comply with Confederate peace demands, Davis telegraphed both Beauregard and Bragg the message that "Our Commissioners at Washington have received a flat refusal." Davis, sensing what was coming, then dashed off a letter to the Confederate governors, asking them for 20,000 more troops. $^{732}$

Meanwhile two Federal envoys, Robert S. Chew and Captain Charles Talbot, had arrived in Charleston to meet with Governor Pickens. At the meeting Chew read the following message: ${ }^{733}$

I am directed by the President of the United States to notify you to expect an attempt will be made to supply Fort Sumpter (sic) with provisions only; and that, if such attempt be not resisted, no effort to throw in men, arms, or ammunition, will be made, without further notice, or in case of an attack upon the Fort. ${ }^{734}$

Beauregard then wired Davis that an "Authorized messenger from Lincoln just informed Governor Pickens and myself that provisions would be sent to Sumter peaceably, otherwise by force." Davis wired back through Secretary of War Walker that "under no circumstances" should Beauregard allow provisions to be sent to Fort Sumter. At that Beauregard ordered all military forces in Charleston to man their posts. ${ }^{735}$

\footnotetext{
731“Leroy P. Walker, Secretary of War, to Beauregard,” April 6, 1861, $\underline{\text { O-R, }} 285$.

${ }^{732}$ Current, 147-148; "Walker to Pickens," April 8, 1861, O-R., 290.

${ }^{733}$ Simon Cameron, Speeches and Writings, 294-295; Bates, 181; "Beauregard to Major Robert Anderson,"

734 "Theo. Talbot to Simon Cameron," April 12, 1861; "Beauregard to Walker," April 8, 1861; "Pickens to Beauregard," April 9, 1861, all in O-R, 251, 290 \& 291.

735“Walker to Beauregard, April 2, 1861,” O-R, 285.
} April 9, 1861,-2:15 p.m., O-R, 250. 
The next day, April 9, Fox departed New York and headed for Sumter. Pickens and Beauregard, meanwhile had intercepted several letters which revealed that Anderson had known for weeks, or at least suspected, that the Federal government had no intention of surrendering Sumter and that a relief expedition was on the way. Pickens sent Davis an urgent telegram informing the president that war had been "inaugurated by the authorities in Washington ... You will see by these letters how it is intended to supply the fort." Davis immediately summoned his cabinet to discuss the situation. At the meeting that evening Davis asked several crucial questions: assuming the message was genuine how should they react to it? Should he let stand the orders already issued to Beauregard or have him attack the fort at once, before the relief expedition arrived? ${ }^{736}$

Having reached no definite conclusions Davis reconvened his cabinet the next day, April 10, to continue the discussions over what to do about Sumter. Like Governor Pickens, many in the cabinet felt betrayed by the Union government and especially by Seward who had assured them that Sumter would be surrendered. It was clear now that this had been a mere ruse to buy time while preparations were completed for the relief of Anderson. Davis, who had so warned Beauregard only a few days before, and who by now had had enough, advocated an immediate attack against Sumter, a course endorsed by a majority of the cabinet. In the middle of the cabinet discussion, Davis received a rather long telegram from his old friend Senator Lewis Wigfall of Texas, who was now in Charleston, which warned him that the Federal government was using the delay "To complete his preparations. All here is ready on our disadvantage. ... Let

${ }^{736}$ Bares, 181; "Pickens to Davis," April 9, 1861; "Pickens to Davis" (with enclosures), April 9, 1861, both in $\underline{\mathrm{O}-\mathrm{R}}, 292,293-294$. 
us take Fort Sumter before we have to fight the fort and the fleet." Davis then dashed off the following message to Beauregard: ${ }^{737}$

If you have no doubt of the authorized character of the agent who communicated to you the intention of the Washington Government to supply Fort Sumter by force, you will at once demand its evacuation and if this is refused, proceed in such manner as you may determine to reduce it. Answer. ${ }^{738}$

Beauregard protested that he still needed another twenty-four hours to get ready. ${ }^{739}$

The next day, April 11, at Charleston, General Beauregard made his final preparations for war. Throughout the day discussions went on between Major Anderson and three of Beauregard's aides, Colonel James Chesnut, Lt. Colonel A.R. Chisolm, and Captain Stephen D. Lee. ${ }^{740}$ After delivering an ultimatum to Anderson at about 3:15 a.m., which was rejected, one hour later, at 4:30 a.m. April 12, 1861, the Confederate batteries opened fire on Fort Sumter. ${ }^{741}$

${ }^{737}$ The one exception was Secretary of State Robert Toombs. Toombs, much like his northern counterpart, urged restraint and told Davis that his message to Beauregard "puts us in the wrong. It is fatal." Meredith, 152; Current, 151-152.

${ }^{738}$ Walker to Beauregard, April 10, 1861, O-R, 297.

${ }^{739}$ Beauregard to Walker, April 10, 1861, Walker to Beauregard, April 10, 1861, Beauregard to Walker, April 10, 1861, all in $\underline{\mathrm{O}-\mathrm{R}}, 297$.

${ }^{740}$ Lee, "First Shot", 75-6; Beauregard to Anderson, April 11, 1861, O-R, 13; Anderson to Beauregard, April 11, 1861, O-R, 13; Beauregard to Anderson, April 11, 1861, O-R, 13-14; Beauregard to Walker, April 11, 1861; Beauregard to Walker, April 11, 1861; Walker to Beauregard to Walker, April 11, 1861; Beauregard to Roman, Crawford and Forsyth, April 11, 1861, all in O-R, 300 \& 301; Anderson to Beauregard, April 12, 1861, O-

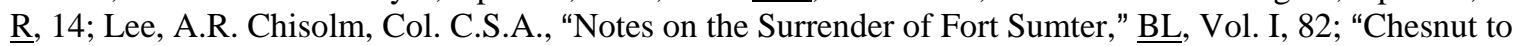
Anderson," April 12, 1861, 3: 20 a.m., O-R, 14; "Walker to Beauregard," April 12, 1861, O-R, 305; "Beauregard to Walker," April 12, 1861, $\underline{\mathrm{O}-\mathrm{R}}, 305$.

${ }^{741}$ O.-R., 13-15; "Engineer Journal of the bombardment of Fort Sumter, By Capt. J.G. Foster, Corps of Engineers, U.S. Army, O.R., 16025; Rise and Fall, 68, 244, 254 \& 277; James Chester, Capt. Third Artillery, U.S.A., "Inside Sumter in '61," BL, I, 65; Lee, "First Step," 76; The Diary of Edmund Ruffin, Volume 1: Toward Independence, October 1856-April 1861) 2 Vols, Edited by William K. Scarborough, (Baton Rouge: Louisiana State University Press, 1972) 588. 
Thirty-four hours later, at 2:30 p.m. on April 13, 1861, Major Anderson surrendered. ${ }^{742}$

The impact of masculinity upon these events was profound and crucial. Indirectly societal forces wielded a profound influence on the political leadership at the time. Since only men could vote, it was only natural that the politics of that era would be strongly influenced by contemporary ideas of masculinity and manhood. As has already been stated $19^{\text {th }}$ Century Americans expected their political leaders to act like men--to conform to a certain standard of behavior which included being candid, forthright, courageous, sincere, frank, intelligent, faithful, physically strong and not afraid of hard work. ${ }^{743}$ Indeed there was a considerable body of opinion which held that republican government was reliant upon manliness for its very survival. $^{744}$

To a very large degree Americans, and especially Southerners, equated manliness with character and honesty. Real men had the courage to speak their minds regardless of the consequences; cowards prevaricated or outright lied to avoid responsibility. ${ }^{745}$ Northern voters were no less likely to choose candidates whose values reflected their own.

As successful politicians chosen by an exclusively male electorate it is reasonable to conclude that both Lincoln and Davis would have been keenly aware of antebellum ideas of masculinity. If nothing else they would have had to be sensitive to such values and ideas in

\footnotetext{
${ }^{742}$ The only casualties during the siege occurred at the surrender ceremonies on April 14 when an explosion accidentally killed one soldier and seriously wounded two others. Chester, 72-73; "Beauregard to Walker," April 13, 1861, O.R., 310; Lee, "First Step,” 79-81; Chisolm, "Notes,” 82-83; McPherson, Battle Cry, 274.

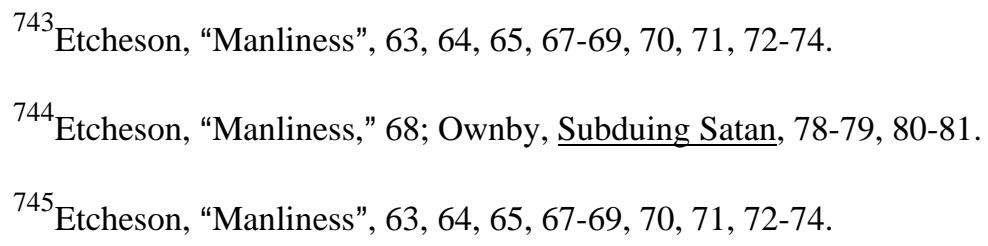


order to preserve their position. And there is every reason to believe that not only were Lincoln and Davis sensitive to these attitudes but that they embraced them as well. As a young politician in the 1840s, Lincoln had witnessed a great deal of "political violence." One such incident involved Stephen Douglas who, "having chosen to consider himself insulted" by a newspaper report, tried to cane the editor, Simeon Francis. Even Lincoln himself became involved in an "affair of honor" with a politician over some insulting letters Lincoln had written to the Sangamo Journal." ${ }^{746}$ Furthermore, honor was of such concern to Davis that he spent the last years of his life engaged in a campaign to justify his own actions and those of the South. ${ }^{747}$

Lincoln understood from the start that he had to stand firm against the rebels or Republicans would desert the administration and the party would fall to pieces. Second, it was a psychological necessity, otherwise the Confederates would claim a victory and this would invigorate their cause. If Lincoln needed confirmation of this, he need only consult his daily mail which overflowed with unsolicited advice from Republican strategists all across the North urging him to stand tough against the Confederates. Typical were such comments as "Give up Sumpter (sic), Sir, \& you are as dead politically as John Brown is physically. You have got to fight." And "Give those South Carolina ruffians h-l, and we will support you."748 On March 28, Lincoln's close friend Republican Senator Lyman Trumbull of Illinois introduced a resolution into the Senate which called upon Lincoln "to use all the means in his power to hold and protect

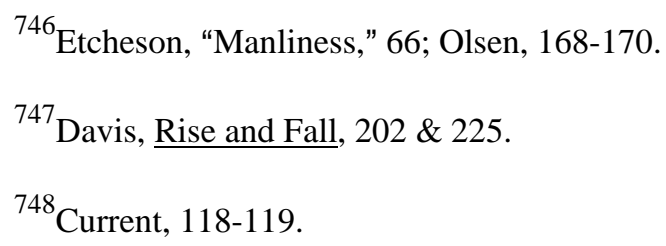


the public property of the United States, and enforce the laws thereof." ${ }^{749}$

Certainly Lincoln was aware of the damage that could be done by appearing weak. He was determined to present to the world and especially to the South an image of resolute strength. The need for such determination was made all the more urgent by the actions of Lincoln's predecessor, James Buchanan, a man who inspired neither fear nor confidence. "The Old Public Functionary," as Buchanan called himself, was a political veteran of more than forty years experience during which he had served in both the House and Senate, as a diplomat at St. Petersburg and London and as James Polk's Secretary of State. ${ }^{750}$ Whether it was because of his age or physical infirmity, Buchanan was a painfully weak president who sat idly by, throughout his four years in office, and did nothing while the nation drifted from one crisis after another, beginning with the Dred Scott decision and continuing on through "Bleeding Kansas," the Lincoln-Douglas debates, John Brown's raid, the Election of 1860, and South Carolina's secession. ${ }^{751}$

Each of these episodes represented an important crossroads in the Sectional crisis. Decisive action on Buchanan's part during any of them might have prevented the war. But in each instance Buchanan failed to act. Once the crisis of 1860-61 was at hand Buchanan made it clear that he intended to continue his policy of inactivity. His December 4, 1860, State of the Union message, in which he condemned secession but declared that the federal government was

${ }^{749}$ Current, 77; Klein, 307-308.

${ }^{750}$ David M. Potter, The Impending Crisis, 1848-1861 (Completed and edited by Don E. Fehrenbacher) (New York: Harper \& Row, 1976) 1, 69, 141, 182, 189-190, 287.

${ }^{751}$ Potter, 259-267, 275-288, passim, 300-318, passim, 325. 
powerless to stop it, left no doubt that Buchanan intended to ride out the storm until Lincoln arrived. $^{752}$ In fact Buchanan's appointment of Major Anderson to command of the Charleston garrison was at least partly a token of appeasement to the South. As a Southerner, one married to a South Carolinian at that, Anderson could presumably be relied upon not to give offense. ${ }^{753}$

Buchanan's sole display of backbone came on January 9, 1861, when a relief expedition, acting on Buchanan's orders and featuring the merchant steamer Star of the West, tried to sneak into Charleston harbor under cover of darkness. In an incident that some interpret as the opening shots of the Civil War, the Star of the West was detected and fired upon by nearby Fort Moultrie, and forced to withdraw. ${ }^{754}$

Buchanan's lack of resolve, made it all the more important that Lincoln not waiver nor give in to southern demands. As Lincoln wrote to one political supporter:

What is it I could say which would quiet alarm? Is it that no interference by the government, with slaves or slavery within the states, is intended? I have said this so often already, that a repetition of it is but mockery, bearing an appearance of weakness, and cowardice, which perhaps should be avoided. Why do not uneasy men read what I have already said? and what our platform says? If they will not read, or heed, then, would they read, or heed, a repetition of them? Of course the declaration that there is no intention to interfere with slaves or slavery, in the states, with all that is fairly implied in such declaration, is true; and I should have no objection to make, and repeat the declaration a thousand times, if there were no danger of encouraging bold bad men to believe they are dealing with one who can be scared into anything. ${ }^{755}$

${ }^{752}$ Buchanan was so determined to avoid trouble that he actually met with the South Carolina peace commissioners, although he regarded them as "private gentlemen" and not as representatives of a foreign government. Davis, Hour, 288; Long, 4, 6, 8-10; Potter, 56-57; 259-267, 275-288, passim, 300-318, passim, 325.

${ }^{753}$ Ibid.; Davis, $\underline{\text { Hour, 286, 288, } 290 .}$

${ }^{754}$ Davis, Hour, 291-293; J.G. Foster, Captain, Engineers, "Extract from Annual Report (October, 1861) of

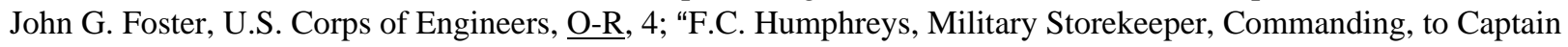

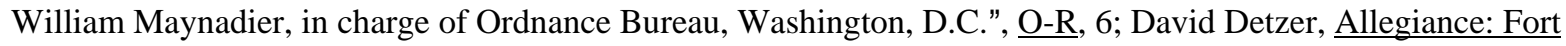
Sumter, Charleston, and the Beginning of the Civil War, (New York: Harcourt, Inc., 2001) 131.

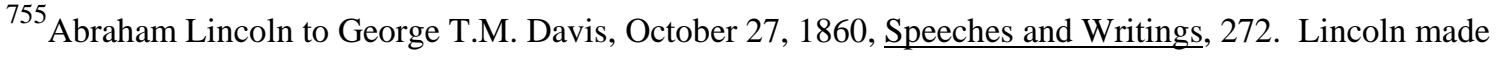


Regional prejudices also exerted a powerful influence on Lincoln. Many Northerners, tired of kow-towing to the arrogant "cotton snobs" urged Lincoln to strike a blow. Among the loudest of these voices came from Frank Blair, father of Lincoln's Postmaster General Montgomery Blair, and a prominent border state politician from Maryland who was a bitter enemy of the planter elite. Following the March 18 cabinet meeting, in which the cabinet had voted solidly against the idea of re-supplying Sumter, Frank Blair blustered his way into the White House to confront Lincoln. When Blair demanded to know if the rumors were true that Lincoln planned to give up Sumter, the president could only weakly reply that a majority of the cabinet seemed to favor the idea. Blair, in an apparent attempt to shame Lincoln into action, replied hotly that to do so "would be treason."

Montgomery Blair was even more explicit than his father in urging upon Lincoln the need to stand up to the South. According to Blair:

The real cause of the trouble, arises from the notion generally entertained at the South that the men of the North are inferiors, and the rebellion springs altogether from pride which revolts against submission to supposed inferiors. You hear these blusterers say everywhere that one Southern man is equal to half a dozen Yankees, and that feeling has impelled them to appeal from the Constitutional mode of determining who shall govern, to arms. They will not submit, they say, to mere numbers made up of the Mudsills, the

several similar statements during the crisis. On December 11, 1860, he wrote to William Kellogg: "Entertain no proposition in regard to the extension of slavery. The instant you do, they have us under agin; all our labor is lost, and sooner or later must be done over. Douglas is sure to be again trying to bring in his "Pop.Sov." Have none of it. The tug has to come \& better now than later." to James P. Hale 1/11/61: "We have just carried an election on principles fairly stated to the people. Now we are told in advance, the government shall be broken up, unless we surrender to those we have beaten, before we take the offices. In this they are either attempting to play upon us, or they are in dead earnest. Either way, if we surrender it is the end of us, and of the government. They will repeat the experiment upon us ad libitum. A year will not pass, till we shall have to take Cuba as a condition upon which they will stay in the Union ..." Abraham Lincoln to William Kellogg, December 11, 1860:; Abraham Lincoln to James T. Hale, January 11, 1861, both in Speeches and Writings, 273 \& 276.

\footnotetext{
${ }^{756}$ Welles, 13-14; Current, 56-7.
} 
factory people and shopkeepers of the North. They swell just like the grandiloquent Mexicans. And I readily fear that nothing short of the lesson we had to give Mexico to teach the Spanish don better manners, will ever satisfy the Southern Gascons that the people of the North are their equals even upon the field upon which they have now chosen to test the question. ${ }^{757}$

In Blair's view to yield "in the slightest" to Southern demands would only serve them by increasing their "contempt for the North." If Lincoln hoped to preserve the Union, the thing to do was to stand firm in opposing secession, by force if necessary. In fact, in Blair's view violence might be not only necessary but desirable: "War--'the application of force involving the destruction of life'--would be the quickest and most effective means of bringing the sections together again."758 In other words, once the North had stood up to the South, "shown them who was boss' in other words, the arrogant "southrons" would cease their endless threats and demands and on that basis "true Unionism would return."759

But before Lincoln could confront the rebels he first had to establish dominance over his own cabinet. Unlike Davis who chose a cabinet composed largely of non-entities, and who seemed to base his appointments as much on state rights as on administrative ability (each of the seven Confederate states had at least one representative in the cabinet), Lincoln "deliberately sought out the most capable advisors he could."760 Lincoln's cabinet, which consisted of Secretary of the Interior, Caleb Smith; Attorney General, Edward Bates; Postmaster General,

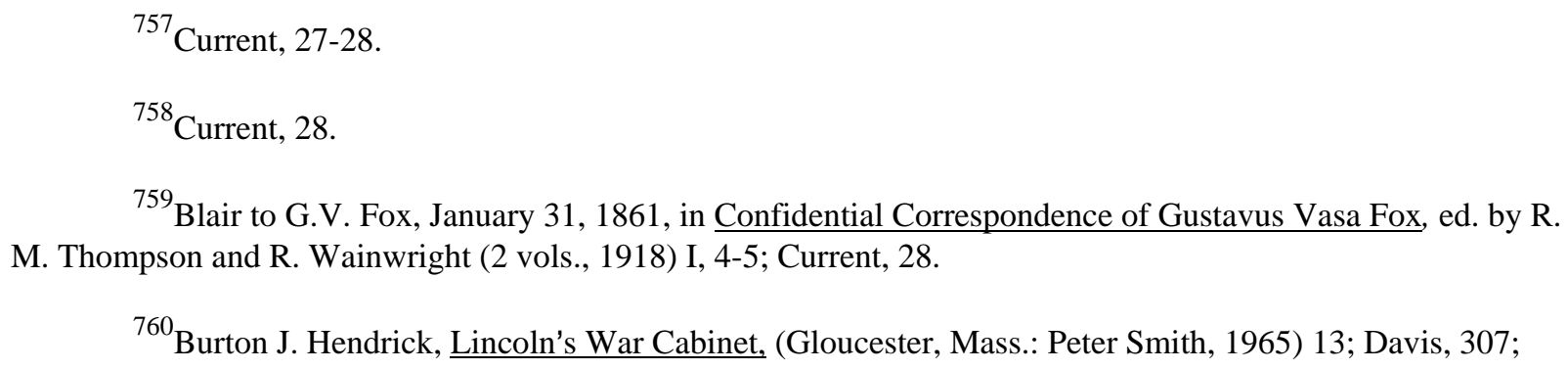


Montgomery Blair; Secretary of the Navy, Gideon Welles; Secretary of War, Simon Cameron; Treasury Secretary, Salmon Chase and Secretary of State, William Seward, was of the most accomplished yet troublesome in the history of the Republic. Three of them had been Lincoln's rivals for the Republican nomination in 1860, and almost none of them thought Lincoln equal to the challenges that faced him. ${ }^{761}$

The two ablest cabinet members, Chase and Seward, were also the most troublesome. Both had sought the Republican presidential nomination in 1860 (Chase would try again in 1864) and both were convinced that the voters had made a grave mistake in not choosing them. Each was in his own way brilliant, but their brilliance bred an arrogance that often put them at odds with their colleagues and with their chief. But in the end what proved most troublesome about the two was the fact that they detested each other. So deep was the hatred between them that only two days before the inauguration Seward threatened to resign if Chase was not dismissed. This was a transparent attempt at political blackmail and Lincoln, to his credit, refused to give in to it. $^{762}$

Of the two Seward posed the greatest challenge to Lincoln's leadership but he also proved to be his most valuable advisor. Born in 1801, Seward had made a name for himself

${ }^{761}$ Secretary of War Cameron was easily the least competent member of this group and owed his position to convention bargaining. Cameron's corrupt practices eventually led to his dismissal and replacement by Edwin M. Stanton. Current, 45-49; Burton J. Hendrick, Lincoln's War Cabinet, (Gloucester, Mass.: Peter Smith, 1965) 13, 65-66, 74, 89-90 261-266, 275 \& 277; Davis, 307; Long, 39-40, 56-57; 80; Current, 45-49.

${ }^{762}$ Richard Current in Lincoln and the First Shot, characterized this incident as a political game of "chicken": "with his resignation, (Seward) represented to Lincoln the dilemma of either losing his-Seward'spresumably indispensable advice and support or else remaking the cabinet so as to assure him the upper hand. Lincoln, however, decided to reject both alternatives. While the inaugural parade was forming in the streets, he wrote a letter asking Seward to withdraw hi resignation. As Lincoln handed the letter to his private secretary to copy, he remarked: 'I can't afford to let Seward take the first trick.'” as cited in Current, 37; see also Hendrick, 14, 34, 43-44, 52; Current, 34-35, 45-49 and Davis, Rise and Fall, 291-293. 
among radical abolitionists with his "Irrepressible Conflict" and "Higher Law" speeches that many interpreted as calling for an inter-sectional war to end slavery. ${ }^{763}$ This perceived radicalism both endeared Seward to Abolitionists and led the Republican Convention to pass him by in favor of the more moderate Lincoln. Still, William Seward was not one to let a small matter like an election prevent him from wielding power. Citing Lincoln's perceived unfitness for office, Seward made it clear from the start that he, and not Lincoln, was really going to wield power. ${ }^{764}$

As a Senator Seward had already exerted a dominating influence over the Zachary Taylor administration and he saw no reason why, as Secretary of State he should not exert a similar influence over Lincoln's. ${ }^{765}$ In fact Seward had tried to influence events even before he became Secretary of State, by calling for a Constitutional Amendment that forbade Congress from ever interfering with slavery where it already existed; restricted slavery from expanding into the territories; granted jury trials to fugitive slaves; and revised personal liberty laws. But despite his reputation for radicalism, Seward's plan for dealing with the crisis was to be far less strident than Lincoln's. Seward was convinced that secession was nothing more than a large-scale protest movement and that the best way to deal with it was through patience and kindness, much as a parent dealt with a recalcitrant child. ${ }^{766}$ Unfortunately Seward was not content to merely hold ideas different from Lincoln's, he also felt the need to act on them. Among other things Seward carried on a surreptitious correspondence with the rebels throughout the month of March, and

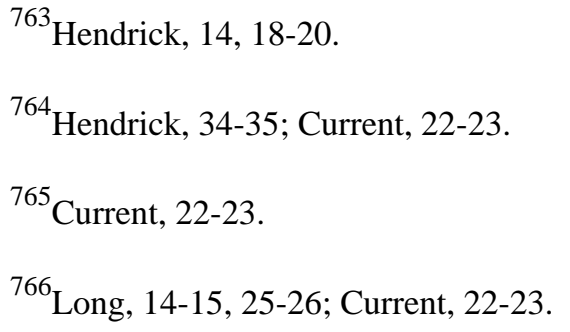


actively worked to undermine Lincoln's policy by repeatedly assuring the Confederates that Sumter was about to be surrendered. ${ }^{767}$

As a result of this deliberate undermining of policy the administration, throughout much of the crisis, would be acting at cross-purposes. While Lincoln was doing everything in his power to show firmness toward the rebels, Seward was seemingly doing everything in his power to placate them. In other words, the highest official in Lincoln's cabinet was actively working to undermine the president's authority. ${ }^{768}$ This situation had unfortunate consequences both in that it gave the South mixed signals and gave the impression that Lincoln's cabinet, like Buchanan's, was out of control. ${ }^{769}$

Meanwhile, as the Sumter crisis approached its climax, matters were also coming to a head between Lincoln and Seward over what policy should be pursued in regard to Sumter. While Lincoln had all along declared his intention to hold Sumter, Seward had been playing a double-game, secretly meeting with Confederate representatives and assuring them that Sumter would be surrendered. Since early March the Confederate Peace Commissioners, Martin J. Crawford, John Forsyth, and A.B. Roman, acting through their unofficial "envoy" Supreme Court Justice John A Campbell, had sought to open negotiations with the Lincoln Administration. ${ }^{770}$

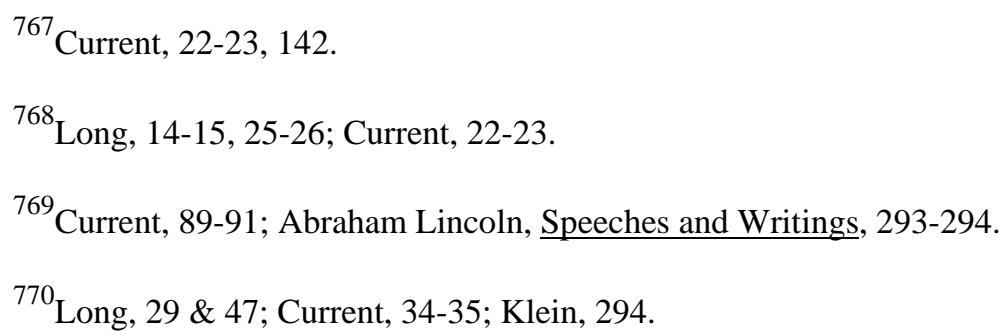


At the first meeting between Seward and Campbell, the Confederates threatened to attack Sumter immediately, but then agreed to wait twenty days on condition that the Union also take no action, came to nothing. Ultimately nothing came of this "overture." Still Seward continued to secretly correspond with the Confederates throughout the month of March, all the while assuring them that Sumter would be surrendered. ${ }^{771}$

By the end of March it was becoming apparent to everyone, even the Confederates, that Lincoln had no intention of either abandoning Sumter, or of allowing Seward to control his administration. Earlier, on March 29, Seward had made one last effort to head off the Sumter relief mission, calling on Montgomery Meigs to try to convince Lincoln that Sumter was "not the place to make the war." Much to Seward's chagrin, Lincoln was not interested in Meigs's views, he wanted to know why his orders for the relief of Fort Pickens had not been carried out. ${ }^{772}$ On March 30, the day after Lincoln ordered that the Sumter expedition go forward, Seward met again with Justice Campbell who handed him a telegram from Governor Pickens demanding to know the reasons for the delay in evacuating Sumter. Seward, embarrassed, was forced to admit that he could not answer until he met with Lincoln on April 1. ${ }^{773}$

Monday, April 1, brought more frustration for Lincoln, much of it courtesy of Seward. On the same morning that he received word that the U.S.S. Brooklyn had not received his orders for the relief mission to Fort Pickens, Monty Blair came to him with word from Fox that the Sumter expedition was being unnecessarily delayed by two New Yorkers: William H. Aspinwall,

\footnotetext{
${ }^{771}$ Davis, Rise and Fall, 262-263; Klein, 333.

${ }^{772}$ Seward memorandum, March 29, in Lincoln Papers, accessed through Memory; Current, 82-83.

${ }^{773}$ Davis, Rise and Fall, 425; Current, 89-91.
} 
who had donated the steamer Baltic, and a "Captain Marshall.” Both had originally agreed to aid Fox's plan and both were now refusing to do so. Apparently the two were associates, or at least admirers, of Seward. Aspinwall at least said he would only cooperate if Seward gave his approval. This apparent tampering by Seward with a policy that he was pledged to carry out, enraged Blair and must have made even Lincoln wonder on whose side Seward was. ${ }^{774} \backslash$

This was an amazing display of gall, but there was worse to come. Later that same day Seward presented Lincoln with a document entitled "Some Thoughts for the President's Consideration" in which he criticized Lincoln for having no policy "either domestic or foreign." He then made a series of unsolicited policy recommendations: "change the question from one upon slavery" to one "upon Union or Disunion"; abandon Sumter but defend Pickens and the other forts on the Gulf of Mexico; in foreign policy: seek confrontation and even war with Spain, France or perhaps Britain, as a way of restoring national unity. While these "recommendations" were open to debate, of one thing Seward was certain: ${ }^{775}$

whatever policy we adopt, there must be an energetic prosecution of it. For this purpose it must be somebody's business to pursue and direct it incessantly. Either the President must do it himself, and be all the while active in it, or Devolve it on some member of his cabinet. $^{776}$

Seward ended with the brazen assertion that if the president was unwilling or unable to do it, then he (Seward) would offer to lead the government in Lincoln's stead. Here is where

${ }^{774}$ Fox, in his message from New York attributed Aspinwall's and Marshall's hesitancy to the fact that the government was going to float a loan on the New York money markets on April 2. "Mr. A. and Capt. M. say the loan would not be taken if this news leaked out." Current, 84-87; Welles, 17-20.

${ }^{775}$ William A. Seward, "Reminiscences," The Collected Works of Abraham Lincoln 9 Vols., Edited by Roy P. Basler, Marion Delores Pratt, and Lloyd A. Dunlap. (New Brunswick, New Jersey: Rutgers University Press in association with the Abraham Lincoln Association, 1953-55) (hereafter, C.W.) 316-318.

${ }^{776}$ Ibid., 318. 
Lincoln showed that he was no James Buchanan. No doubt acting on a rage that had been building for days, Lincoln quickly put Seward in his place, countering Seward's gratuitous advice that "it must be somebody's business to pursue and direct it (i.e. policy) incessantly" by stating flatly that "if this must be done, I must do it." The message could not have been clearer, when Lincoln wanted Seward's opinion he would ask for it. ${ }^{777}$

Much has been written concerning Seward's conduct during this period. Some have wondered if Seward really believed that he could bring Lincoln around to his position or if the two of them deliberately operated at cross-purposes in order to convince Southern moderates that unless they returned to the Union, they would have to deal with the more strident Lincoln rather than the accommodating Seward. While it is dangerous to try to divine the thoughts of others, especially those who are long dead, still in view of subsequent events there can be little doubt that Seward sincerely believed in his policy and believed that his views would eventually prevail. There is no better evidence for this than Seward's memorandum of April 1, "Some thoughts for the President's Consideration." This remarkable document, striking even to the modern reader for its sheer chutzpah, was clearly an act of desperation. Even after Lincoln forbade him from meeting with the Confederate Peace Commissioners, Seward continued to carry on a surreptitious correspondence with the rebels for several weeks, and actively worked to undermine Lincoln's policy by repeatedly issuing personal assurances that Sumter was about to be surrendered. ${ }^{778}$

\footnotetext{
${ }^{777}$ Ibid.; Current, 91; Abraham Lincoln, Speeches and Writings, 293-294.

${ }^{778}$ Current, 142; Long, 47, 49, 51.
} 
No doubt, Jefferson Davis felt pressures that were at least as intense as those felt by Lincoln. Davis might foreswear the use of force, except in self-defense, and might even claim that the Confederacy desired nothing more than "to be let alone" but the truth was that Davis was also being driven toward war by pressures that were almost too strong to be resisted. Davis's first order of business, after his inauguration, was to select the members of his cabinet ${ }^{779}$ Davis's $^{\text {'s }}$ cabinet included Secretary of State, Robert Toombs; Secretary of the Navy, Stephen Mallory; Attorney General, Judah Benjamin; Postmaster General, John Reagan; Secretary of the Treasury, Christopher Memminger; and Secretary of War, Leroy Pope Walker. It was a study in mediocrity. ${ }^{780}$ With the possible exception of Attorney General Benjamin none of them were men of superior ability and apparently that was exactly how Davis wanted it. ${ }^{781}$

As president, Davis, tried to bring a sense of military order to government. Again, unlike Lincoln who readily delegated authority, Davis kept a tight rein on his subordinates, and especially on Walker. ${ }^{782}$ As a professional soldier Davis naturally regarded the War Department as being within his personal purview. Hence Davis often acted as his own Secretary of War and treated Walker as a glorified clerk. But in some respects Davis's military background was a liability. It bred arrogance in Davis: an aversion to compromise and an insistence on obedience

\footnotetext{
${ }^{779}$ Davis, 307; Long, 39-40.

${ }^{780}$ Davis, Rise and Fall, 202, 225, 241-243.

${ }^{781}$ Current, 128.

${ }^{782}$ Ibid.
} 
that were ill-suited to the needs of a popular government, especially one as averse to central authority as the Confederacy. ${ }^{783}$

The architects of secession strove, in every way possible to present to the world, and especially to the border states, the image of a constrained, legal and moderate resistance movement. It was of the utmost importance to the Confederacy's survival, that it not be tarnished by the slightest hint of radicalism. ${ }^{784}$ But such unity was deceptive. Throughout the South turmoil boiled just beneath the surface between various factions: former Whigs vs. former Democrats; "original secessionists" vs. "recent converts." Other battles raged over the reopening of the slave trade, the possible admission of new states to the Confederacy and military policy. The longer the Sumter Crisis dragged on the more severe these divisions seemed likely to become. Added to these factors were economic concerns, which also seemed likely to worsen the longer the Crisis lingered. ${ }^{785}$

Southern regional prejudices also had a telling effect. To most Southerners Yankees, and especially abolitionists, were "cowards who had been degraded by their pursuit of gain, by their devotion to commerce, manufactures, and the base mechanical arts. They would never fight unless the odds were overwhelmingly in their favor." ${ }^{786}$ Rather than provoking a war, a preemptive strike might be the best guarantor of peace. According to Southern fire-eaters like Robert B. Rhett, the North was far too cowardly and factionalized "to risk hostilities against a

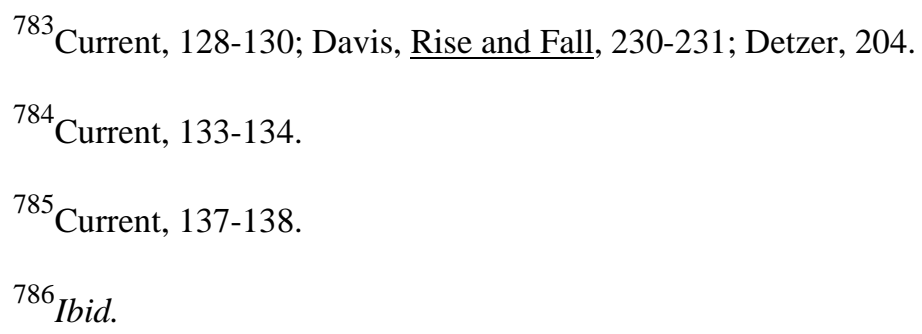


united South. By taking Sumter by force it would demonstrate to the North that the South meant business." ${ }^{787}$ All of these factors seemed to argue in favor of the South striking sooner rather than later. $^{788}$

Furthermore, as Bertram Wyatt-Brown pointed out in Southern Honor, in the minds of southerners militarism was closely linked to matters of manhood and self-worth. In other words many southerners had a positive taste for fighting, shooting, hunting and other "manly" activities. War, rather than something to be avoided, was a positive good, it was an opportunity for glory or at least to prove one's worth as a man. So, despite Davis's protestations of peaceful separation, the potential need to resort to force was never far from his mind. As Richard Current wrote in Lincoln and the First Shot: ${ }^{789}$

Davis . . . had too many panting soldiers to think of, too many blood-minded enthusiasts to take into account. If he should retreat, the Confederacy would have little chance to grow or even to live. His own position of leadership would be imperiled. The hot-headed Carolinians might take the initiative from him. They might begin firing at any moment, regardless of instructions from Montgomery. ${ }^{790}$

As Current also points out, many Confederates dreamed of an empire that would extend far beyond just the Lower South. Freed from the constraints of abolitionist interference, the Confederacy might well subsume not only the Cotton states but much of the North as well (except New England of course). It might even conquer Mexico, Central America, the

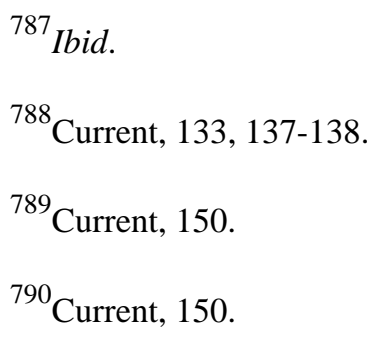


Caribbean Islands, perhaps all of the Western Hemisphere. Faced with such aggressive southern nationalism, Davis could not afford weakness if he was going to survive politically. ${ }^{791}$

The pressure for Davis to act was immense. The longer he delayed, the weaker both he and the Confederate government appeared and the less likely it was that Virginia or any other border state, without which the Confederacy stood little chance of survival, would cast their lot with the new republic. Unless Davis showed an ability to lead and a capacity for decisive action, it would shake the confidence of those states that had already seceded. With their confidence shaken the Confederate States might slowly, one-by-one, drift back to the Old Union and the Confederacy die before it had hardly begun. ${ }^{792}$ If he hoped to avoid this fate Davis had to act: "Something must be done, and soon. Evacuation or expulsion! Get the Yankees out of the Southern forts! Expulsion might lead to war, of course, but war was by no means the worst of possible evils.,"793

It thus becomes relatively simple to see how masculine virtues influenced the decision to go to war. First, politically, there were two diametrically opposed positions. Lincoln maintained that secession is impossible, Davis held that secession was the inalienable right of each sovereign state. ${ }^{794}$ These are two irreconcilable positions, for one man to succeed the other must fail, for one man to triumph the other must surrender the proverbial irresistible force meeting an

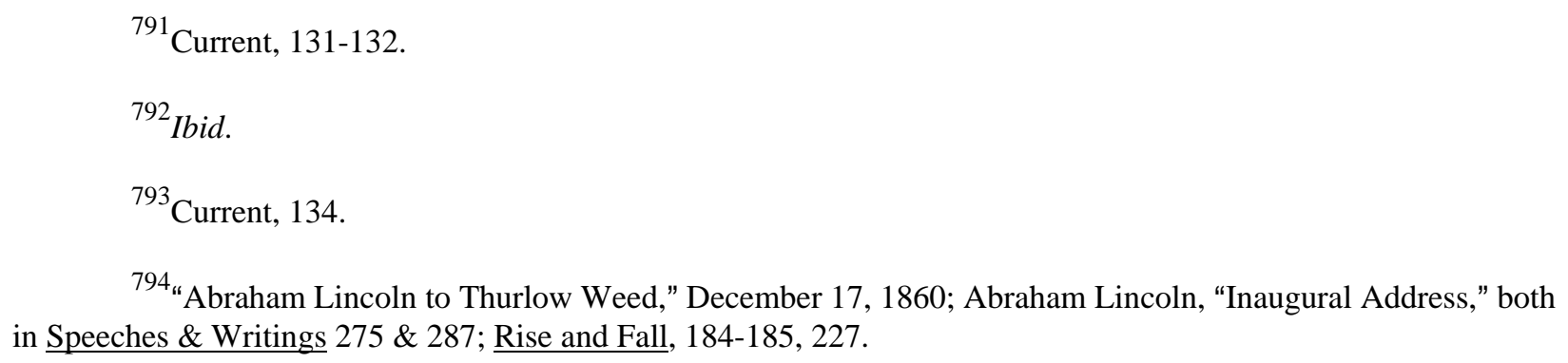


immovable object. Added to this is a characteristic unwillingness to compromise--to back down or to show weakness: Lincoln could not abandon Sumter and Davis could not let him keep it. Given the nature of $19^{\text {th }}$ century ideas of manhood and leadership, despite the fact that both sides forswore resorting to violence, some kind of collision was inevitable. ${ }^{795}$ Simply stated it was what honor and manhood demanded. The only question was who would strike the first blow? Far more complex was the process that dictated which side would strike the first blow and the role that masculine virtue played in that process.

Unlike those scholars, most notably Current, who see Lincoln as weak and vacillating during much of the crisis, I believe the opposite to be true. Lincoln never wavered either in his belief that secession was illegal or in his determination that Sumter would not be surrendered. Lincoln knew from the start what he wanted to do: preserve the Union peaceably if possible, by force if necessary. The first step was to make sure that nothing else was lost to the rebels. The way to do this was to "hold, occupy, and possess" all federal property in the South, starting with Sumter. In so doing Lincoln knew he was pursuing a course that must lead to war. This assessment was grounded in both cold political calculation and a profound understanding of the political realities of the time.

At its heart the Sumter Crisis was a collision between two diametrically opposed positions: Lincoln believed unequivocally that secession was impossible. Davis was just as

${ }^{795}$ DAVIS: In the action which she then took, Mississippi certainly had no purpose to levy war against the United States, or any of them." LINCOLN: "In your hand, my dissatisfied fellow countrymen, and not in mine, is the momentous issue of civil war. The government will not assail you. You can have no conflict, without yourselves being the aggressors." Rise and Fall, 221; Lincoln, Inaugural Address, March 4, 1861, S\&W, $292-293$. 
convinced that secession was an inalienable right of the sovereign states. ${ }^{796}$ These positions were both immutable and irreconcilable; for one to triumph the other must be surrendered. By the same token the men who held those positions were equally irreconcilable. Lincoln could not abandon Sumter and Davis could not let him keep it. Given the nature of $19^{\text {th }}$ century ideas of manhood and leadership, despite the fact that both sides forswore any resort to violence, some kind of collision was inevitable. ${ }^{797}$ The only question was who would strike the first blow? Lincoln was determined that the Confederates would. ${ }^{798}$

And there is a considerable amount of evidence that Lincoln deliberately maneuvered the Confederate government, specifically Jefferson Davis, into striking the first blow. As an experienced and skilled $19^{\text {th }}$ Century politician, Lincoln was well aware of the American tradition of non-preemption. Current in Lincoln and the First Shot described this tradition as follows:

the people are by nature peaceably inclined, and so are their leaders, the government being presumably under popular control. The people will resent insult and repel dangers, but they will not take the initiative in starting a war. . The tradition that the enemy must strike first-and the belief that he always has done so-goes back to the beginning of the very first of distinctively American wars, the War of Independence. ... (when) the redcoat Major Pitcairn approached the Minutemen innocently assembled on the Lexington green...and wantonly ordered his men to fire. ${ }^{799}$

${ }^{796}$ Abraham Lincoln to Thurlow Weed, December 17, 1860, Speeches and Writings, 275; Abraham Lincoln, "Inaugural Address, Speeches and Writings, 287; Davis, Rise and Fall, 184-185, 227.

${ }^{797}$ Davis, Rise and Fall, 221; Lincoln, "Inaugural Address", Speeches and Writings, 292-293.

${ }^{798}$ Davis, Rise and Fall, 53.

${ }^{799}$ Current, 7-9. 
As a young Whig Congressman during the Mexican War, Lincoln had exploited this "tradition" through his "Spot Resolutions" that had demanded to know the exact 'spot' where the alleged Mexican attack on American forces had taken place. Although unsuccessful the "Spot Resolutions" were intended to portray President James Polk as having committed an act of aggression against a weaker neighbor. Now as President Lincoln was exploiting the tradition again, this time to justify, rather than condemn, a war of conquest. ${ }^{800}$

Furthermore, as a fellow Kentuckian, and having been brought up in the rough-andtumble masculinity of the frontier, Lincoln also had a pretty good idea of the kind of man that Jefferson Davis was. Indeed Lincoln knew too well of the pressures that Davis was under and those pressures no doubt entered into his strategic thinking. He was familiar with the writings of Southern "Fire-Eaters" like Robert Barnwell Rhett and Edmund Ruffin and the pressure they could and would exert on Davis to strike a blow. He knew that many Confederates dreamed of an empire that would extend beyond just the Lower South: to the Upper South and the North; perhaps even Mexico, Central America and the Caribbean Islands. Faced with such aggressive nationalism, Davis could not afford weakness if he was going to survive politically. ${ }^{801}$ So while Davis might have preferred to wait, and let hunger do the job, he was determined to get the Union troops out of Sumter, even if it meant war.

It is important to point out that while antebellum masculinity doubtless played a crucial role in the Sumter Crisis events were also strongly influenced by the individual personalities and

${ }^{800}$ In a sense Lincoln and Polk were both playing the same game, attempting to exploit the tradition of defensive warfare for political gain. Current, 7-10.

${ }^{801}$ Detzer, 206-207; Klein, 253-256. 
abilities of the two men involved. In this regard there can be little doubt that Abraham Lincoln was a more skilled politician than Jefferson Davis. Davis owed his election as president more to the fact that he was perceived as holding moderate, even conservative views on secession, than to his political skill. ${ }^{802}$ Davis himself later frankly admitted that he was "better adapted to a command in the field" than to the presidency. ${ }^{803}$ Lincoln, by attempting to run in supplies, although he was committing what was on the surface an act of humanitarianism, was forcing Davis to choose war. As Welles phrased it:

Armed resistance to a peaceable attempt to send provisions to one of our own forts, will justify the government in using all the power at its command to reinforce the garrison and furnish the necessary supplies. ${ }^{804}$

Lincoln, knowing Davis and knowing the South's predilection for violence set a trap for the South, a trap into which Davis walked quite willingly. He symbolically placed a chip upon his shoulder that he knew Davis would not be able to resist knocking off. Davis's background, training, and immersion in Southern values all ensured that Davis would strike the first blow and condemn himself to the role of aggressor. Davis literally could not help himself.

Certainly both Davis and Vice President Alexander Stephens believed that they had been maneuvered into striking the blow and that Lincoln had played a deceitful game, not only with

${ }^{802}$ LETTER FROM HON. DUNCAN F. KENNER OF LOUISIANA (DELEGATE TO CONVENTION WHICH FORMED THE CSA): "This conviction, coupled with his well-recognized conservative views-for in no sense did we consider Mr. Davis extreme, either in his views or purposes-was the deciding consideration which controlled the votes of the Louisiana." Duncan F. Kenner, as quoted in Davis, Rise and Fall, 239; Current, 139.

${ }^{803}$ Davis, Rise and Fall, 230-231.

${ }^{804}$ Seward claimed that he did not hope to avoid war by pursuing alternative policies, merely that Pickens was a better place to begin than Sumter. Welles, 5; William A. Seward, "Diary and Notes on the War," The Works of William H. Seward, George E. Baker, ed., Volume V. (New York: Houghton, Mifflin \& Company, 1884); Current, 80. 
them but even with Major Anderson. Davis and his Peace Commissioners had good reason to feel as though they had been duped by the federal administration, especially by Lincoln and Seward who seemed to have carried out a classic "good-cop, bad-cop" scenario. ${ }^{805}$ As Davis wrote in his post-war memoir:

This account is confirmed by a letter of Mr. Montgomery Blair. The date of the announcement of the President's final purpose is fixed by Mr. Welles, in the next paragraph to that above quoted, as the $28^{\text {th }}$ of March. This was four days before Mr. Seward's appearance given Judge Campbell--after conference with the President--that there would be no departure from the pledges previously given (which were that the fort would be evacuated), and ten days before his written renewal of the assurance--" $\underline{\text { Faith as }}$ to Sumter fully kept. Wait and see!" This assurance, too, was given at the very moment when a messenger from his own department was on the way to Charleston to notify the Governor of South Carolina that faith would not be kept in the matter. It is scarcely necessary to say that the Commissioners had, with good reason, ceased to place any confidence in the promises of the United States Government, before they ceased to be made. $^{806}$

Clearly Lincoln utilized his superior political skills to formulate a trap for Davis and

Davis walked right into it--but it is also a matter of culture-- Davis's background, military training, and immersion in Southern values, especially militarism, all ensured that he would strike the first blow and condemned him to the role of aggressor. Part of the reason was because of Davis's lack of political skill. It is true that Davis was chosen as president less for his political skill than because of his reputation as a political moderate. Davis literally could not help himself-this was a role he was born to play. It was partly a matter of personality, but it can also be understood as being a factor of masculinity. Lincoln, knowing Davis and knowing the South predilection for violence and especially the need for vindication in the Southern mind, set a trap

\footnotetext{
${ }^{805}$ Current, 176-177.

${ }^{806}$ Davis, Rise and Fall, 277.
} 
for Davis. He put a chip on his shoulder that he knew Davis would not be able to resist knocking off.

Lincoln was not looking for a fight but he expected a fight because he understood the southern character and he was determined to place the blame for war on the South and thereby galvanize northern support for the war. Unfortunately Davis was all too willing to oblige

Lincoln. Indeed Davis himself in his post-war memoirs, frankly admitted that he had been duped by Lincoln in to firing on Sumter: "War had come, according to Davis, in consequence of the Lincoln government's 'crooked path of diplomacy."'807

The degree to which Lincoln succeeded in this was attested to by the thousands of proUnion rallies that took place across the North. ${ }^{808}$ Even Lincoln's presidential rival in 1860, Stephen Douglas, jumped onto the pro-war bandwagon. On his way back to Illinois from Washington after Sumter, to rally support for the war Douglas declared to crowd after crowd: "Every man must be for the United States or against it, there can be no neutrals in this war--only patriots and traitors."809

Indeed news of Sumter struck like thunder and galvanized public opinion throughout the

${ }^{807}$ Davis was equally certain that Major Anderson had been deceived just as he had been. Citing a letter to Colonel L. Thomas, Adjutant-General, in which Anderson had protested against G.V. Fox's plan to relieve the garrison, Davis concluded that Anderson had been tricked into staying at Sumter and playing the role of sacrificial lamb, with promises of a relief expedition that Lincoln knew would never arrive Davis, Rise and Fall, 211-212, 217, 219, 284, 292-294; Current, 176-77, 183.

${ }^{808}$ According to Current, Lincoln's secretaries, John G. Nicolay and John Hay, in their biography of Lincoln claimed that Lincoln did not care whether the Sumter expedition succeeded or not. He was "looking through and beyond the Sumter expedition to the new inevitable rebel attack and the response of an awakened and united North." Current, 184-187.

${ }^{809}$ Current, 159-160, 181; Orville H. Browning, The Diary of Orville Hickman Browning, ed. By T.C. Pease and J.G. Randall. (2 vols., 1925-33), vol. 1, 476. 
North. If it is true that Lincoln's goal during the Sumter Crisis was to unify the North by maneuvering the South into firing first, he succeeded brilliantly. The North was shocked and outraged by the South's audacity in having dared to fire on the American flag. Two days after the fort's surrender, April 15, 1861, Lincoln called for 75,000 volunteers to serve for ninety days to put down the rebellion. ${ }^{810}$

In the states of the Upper South, as nowhere else, the war forced people to make harsh choices. In all of these states, in fact in every Southern State with the possible except of South Carolina, there existed sizable pockets of Union loyalists. After Sumter, however, those same Union loyalists, who blamed Lincoln for starting the war and who saw in his call for troops an attempt to coerce the South, rallied to the Southern colors "in opposition to Black Republican oppression and tyranny." ${ }^{811}$ Virginia, Tennessee, Arkansas, and North Carolina, all eventually joined their sister states of the deep South in rebellion. ${ }^{812}$

But across the North thousands of young men eagerly rushed to answer Lincoln's call. ${ }^{813}$ In every Northern city and town, citizens gathered in huge pro-Union rallies like the one George Templeton Strong described at New York's Union Square on May 20, 1861:

The Union mass-meeting was an event. Few assemblages have equaled it in numbers and unanimity. Tonight's extra says there were 250,000 present...Anderson appeared and was greeted with roars that were tremendous to hear. The crowd ... sang "The Star-Spangled

${ }^{810}$ McPherson, Battle Cry, 273-275.

811 "How Virginia was United," Staunton (Va.) Spectator April 30, 1861,2. Data retrieved from The Valley of the Shadow Project: Two Communities in the American Civil War, Copyright 1993-2003, All Rights Reserved, Edward L. Ayers.<http://valley.vcdh,virginia.edu:>; McPherson, Battle Cry, 275-277.

${ }^{812}$ Jones Diary, 3-6.

${ }^{813}$ George Templeton Strong, Diary of the Civil War, 1860-1865, edited by Allan Nevins, (New York: The McMillan Company, 1962), 119, 122, \& 124. 
Banner," and the people generally hurrahed a voluntary after each verse. ${ }^{814}$

Even the press, ever cynical about government actions, came out firmly in support of Lincoln's war policy. To be sure, there were voices of dissent, like the Washington D.C. based

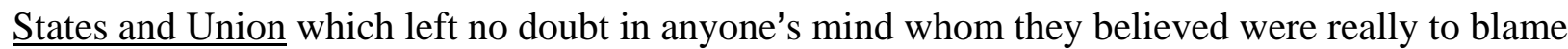
for the crisis:

The Republican Party willfully, wantonly, and maliciously, broke the bond of Union, and now the Republican President of the unconstitutional section of the States issues a proclamation for civil war to keep the Union together. ${ }^{815}$

Similarly the Stephen Douglas mouthpiece, Grand Rapids Daily Register, while it called for every man to do "his duty by sustaining the constituted authorities," still regarded the prospects of sustaining those "constituted authorities" through force of arms with something less than enthusiasm.

What sort of a commentary will History pass upon us? Brothers armed to strike down brothers. Who does not sicken at the thought of all this? And when we reflect upon the cloud which will overhang the domestic heaven, which will darken our streets and rive out the sturdy din of commerce, do not some feelings of sadness come over our souls? Let us meet those dreadful results with manfulness, and yet with sorrow, never with rashness or delight. ${ }^{816}$

But such dissident voices were clearly in the minority. By and large the press, much like the reading public gave voice to an overwhelming flood of patriotic fervor. The Republican press of course led the way in "waving the flag." The following are but a few examples:

${ }^{814}$ The Union Square rally was especially significant in view of the fact that New York City had, prior to Sumter, been very pro-southern in its sympathies. The city's mayor Fernando Wood had even threatened to secede from the Union and claim New York an open city. Strong, Diary, 127; McPherson, Battle Cry, 274.

815 “President Lincoln's Proclamation,” Washington D.C., States and Union, April 15, 1861, in Perkins, II, 765; also "President Lincoln's War," Portland (Me) Eastern Argus, April 15, 1861, in Perkins, II, 765.

816“"The Impending Crisis,” Grand Rapids Daily Register, April 18, 1861, in Perkins, II, 744-746. 
There are no parties now but the party of Union, and party of rebellion: let men take sides. Those who are not for the Union are against it. . .God has great purposes to accomplish by this means, and it would be flying in the face of His Omnipotence not to furnish the volunteers called for by the President. ${ }^{817}$

On one side stands rebellion, treason, anarchy, on the other the government, patriotism, law and order-With one side or the other must all men join. There is no neutral ground between high-handed treason, and the law. ${ }^{818}$

Henceforth among the men of the Free North let there be no party differences or distinctions. Let every man who loves his country, stand by her flag-let him prove his patriotism, by ceasing to be a partisan (sic)--and from this hour, let him swear upon the altar of his common country that he will maintain the free institution, bequeathed to him by the loved and sainted heroes of the American Revolution, to the last farthing of his property, and the last drop of his blood! ${ }^{819}$

But while the Republican press took the lead, even the opposition press eagerly sounded the trumpet:

The Flag of our Country--the glorious Stars and Stripes must be supported and defended by every American. The fight has now begun. An appeal has been made to the God of Battles. . . . Those who have caused the war must answer to their country and their God for what they have done. . . The government which the people have appointed, and which is responsible to the people for its every act, would be direlect (sic) of its duty as a government, if it did not protect its property, its citizens, its flag, and its granted rights against all usurpers, all rebels, all traitors-external or internal foes, of whatever character. $^{820}$

Thus was a pattern set that continued for the next four years: Lincoln displaying the political skill and strategic thinking that would guide the North to ultimate victory, Davis

817 “Chapter 1,” Buffalo Commercial Advertiser, April 1, 1861, in Perkins, II, 734-735.

818 "Roll Up the Curtain and Let the Dance Begin," Chatfield (Minn.) Republican (pro-Lincoln(, April 16, 1861, in Perkins, 741.

819 "Let Us Crush Out Treason, or Perish in the Attempt!!”, Rockford Republican (pro-Lincoln) in Perkins, 744; also "Civil War and Its Consequences," Brooklyn Daily Eagle, April 15, 1861, "The People and The Issue!" New York Times, April 15, 1861, both in Perkins, 771 \& 735.

820 "The War Begun-The Duty of American Citizens," Pittsburgh Post, April 15, 1861, in Perkins, II, 737739; also "Stand by the Flag," The Boston Post, April 16, 1861, in Perkins, II, 739-740. 
displaying a lack of those same qualities that would lead the South to defeat. In this way it can be seen that the seeds of Southern defeat were sown at Sumter. But the question naturally arises, was this a forgone conclusion? Were there viable alternatives? Assuming it was possible to resist the pressure from Rhett, Ruffin, and other militant fire-eaters to attack, what could Davis and the Confederate government have done differently? While it is debatable whether any plan would have worked, the point is that the Confederates, blinded by their prejudices, and driven by their blood-lust, did not even try. 


\section{CHAPTER 9}

\section{CONCLUSIONS}

The American Civil War was the product of complex social, economic, and political forces that affected the United States during the first half of the nineteenth century. To state that any single factor, be it slavery, states' rights, or masculinity, was solely responsible for the Civil War is too simplistic. But while disunion cannot be attributed to masculinity alone, there is no denying that antebellum ideas of manhood played a significant, perhaps decisive, role in bringing on the war.

In the most basic and obvious sense, this was a result of the aggressive nature of masculinity. North and South alike, antebellum American males were a hard-bitten, belligerent lot for whom violence was the preferred method of conflict resolution and the preferred form of entertainment as well. This propensity for violence, coupled with an emphasis upon personal honor and a tendency to view the world in terms of moral absolutes, of course, not only made violent confrontation more likely but almost unavoidable. ${ }^{821}$

But the role of masculinity in bringing on the Civil War was far more complex than that of mere "blood-lust." One of the most important ways in which this occurred was through the misperceptions held by northerners and southerners toward their sectional counterparts.

Southerners typically imagined northerners not as rugged frontiersmen, urban workingmen or

${ }^{821}$ Christopher J. Olsen, Political Culture and Secession, 170, 173, 193, 195; Eugene Genovese, The World The Slaveholders Made, 32-33, 102-105; Edmund S. Morgan, American Slavery, American Freedom, 35; Charles S. Sydnor, Gentleman Freeholders, 5-6; Baldesar Castiglione, The Way of the Courtier, 60-62, 251; Etcheson, "Manliness," 61-2,64, 65, 69-71; Higginbotham, "Martial Spirit," 5; Wyatt-Brown, Southern Honor, 101, 352-62; Cash, The Mind of the South, 79-82; Crowther, "Holy Honor," 619, 623, 627-629, 632, 633. 
hardscrabble farmers but as effete, "pasty-faced," money grubbing Yankees, too busy counting their profits to be concerned with martial pursuits. ${ }^{822}$ As James McPherson notes:

Many Southerners felt contempt for Yankees as "vulgar, fanatical, cheating, counterjumpers." Northerners were cowards: "Just throw three or four shell among those ... Yankees," said a North Carolinian, "and they'll scatter like sheep.",823

To the extent that southerners thought about the Northern laboring class at all, it was in predictably chauvinistic terms. Northern working men were dismissed as mudsills and hirelings little better than slaves and in the view of many southerners, such as George Fitzhugh, no better than slaves at all. ${ }^{824}$ This image of Yankees as the "scum of creation" gave rise to the disastrously mistaken belief that one southerner "could lick ten Yankees." Few southerners dreamed that men like "Butcher Bill" Poole and Jack Armstrong existed, let alone that an army of such men would one day destroy their world. ${ }^{825}$

But southerners saved their harshest criticism for abolitionists and other reform-minded northerners. Abolitionists were almost universally loathed in the South, not only for their condemnation of slavery, but also for allowing women to actively participate in the abolitionist and reform movements. Despite the fact that women were permitted to play only a subordinate role in these organizations, southerners interpreted this liberality as an inability among northerners to control their women. Furthermore, the idea of feminized masculinity, as

${ }^{822}$ Freehling, Road to Disunion (vol. 1) 295.

${ }^{823}$ Allen Nevins, The War for Union: The Improvised War, 1861-1862, 75, 95-96, 151; Bell I. Wiley, The Life of Johnny Reb, 310 as cited in McPherson, Ordeal by Fire, 180.

${ }^{824}$ During an 1856 speaking tour of the Northern states, Fitzhugh suggested that poor whites also be enslaved. Paul Finkleman, Introduction to George Fitzhugh, "Sociology for the South" and "Cannibals All" in Defending Slavery: Pro-Slavery Thought in the Old South, 189.

${ }^{825}$ Op. Cit.; Freehling, Road to Disunion (vol. 1) 295. 
advocated by many reformers, was seen by southerners as not only unmanly but as a sign that abolitionists intended to radicalize society. Little wonder that southerners often regarded abolitionists as being "unsexed freaks." The fact that many Northerners also regarded abolitionists in this way never seems to have occurred to them. ${ }^{826}$

Northern images of southerners were similarly distorted and chauvinistic. To those raised in the competitive, dog-eat-dog, capitalistic society of the antebellum North, the South and its system of plantation slavery seemed hopelessly stagnant, backward and feudalistic. Southern whites were seen as either wealthy, arrogant, cotton snobs or as poor, lazy, ignorant crackers. ${ }^{827}$ Southern planters were seen as intolerant, glory-seeking, 'swells.' Quick to take offense and accustomed to having their way with submissive slaves who had no choice but to obey them, these 'cavaliers' were full of bluster but short on manly courage. To northerners, the cowardly nature of the planter elite was demonstrated by Brooks's assault upon Senator Sumner. Rather than confront Sumner directly Brooks had, in typical southern fashion, chose to strike Sumner when the latter wasn't looking. This, northerners pointed out, was hardly chivalrous, let alone manly, conduct. ${ }^{828}$

Poor southern whites, on the other hand, were viewed either as lazy, shiftless, uneducated brutes whose only solace was the fact that they were, by virtue of skin color, superior to black

${ }^{826}$ Griffin-Wolff, “'Masculinity,” 597, 600-602; Haralson, "Mars in Petticoats,” 329, 336, 346; Hoganson, "Garrisonian Abolitionists," 561, 563, 558-559; Cott, Bonds of Womanhood, 7-8; Baker, "Domestication of Politics," 625; Brown, "Getting in the Kitchen with Dinah," 503-523; Margadant, "Political Imaginary," 1471; McCurry, Masters of Small Worlds, 223, 224.

${ }^{827}$ Freehling, Road to Disunion (Vol. 1) 250; Ash, "Poor Whites in the Occupied South," 47.

${ }^{828}$ Freehling, Road to Disunion (vol. 1) 251; Isaac, The Transformation of Virginia, 1740-1790, 34-42, 131-135; Wertenbaker, 34, 39, 54, 74, 80, 87, 125. 
slaves, or as simmering with resentment at the dominance of the planter class. In the event of war, northerners were certain that such a class of degraded individuals would never fight for a system in which they seemingly had little or no stake. They would either, like the planters, reveal themselves as cowards and shirkers or more likely would welcome northerners as liberators from planter oppression. ${ }^{829}$

These sectional misperceptions not only contributed to a growing alienation between the sections, but the fact that so many of these misperceptions were related to issues of masculinity, led North and South to underestimate the ability and/or the willingness of their counterparts to fight and to overestimate their own ability to do so. As each side came to view the other as less than manly, both came to see their opponents as not being a credible threat. This made both sides more willing to resort to violence as a means of settling their differences.

Among the most grievous misperceptions, one shared by North and South, was the failure to realize that their perceived differences were neither as profound nor as irreconcilable as they seemed to be. Despite their protestations of distinctiveness North and South were much more alike than either of them was willing to admit and, in fact, shared many common traits. Indeed a strong case can be made that their similarities were at least as important as their differences in driving North and South to war, a point made all the more crucial by the fact that many of those similarities were related to, and reflected in, masculinity. ${ }^{830}$

${ }^{829}$ Even Lincoln was guilty of misjudging southern character. He always believed that Union sentiment in the South was stronger than it actually was. Ash, "Poor Whites in the Occupied South, 1861-1865," 47.

${ }^{830}$ Morgan, 35; Sydnor, 5-6. 
Both North and South shared certain assumptions about gender and the nature of manhood. Apart from the fact that both sides equated masculinity with violence and aggression, Northerners and Southerners both closely associated masculinity with politics and expected their political leaders to act like men and to conform to a certain standard of behavior. Both thought that men should be virtuous, faithful, hardworking, physically strong, candid, forthright, courageous, sincere, intelligent, and handy with their fists. Both valued honor; both equated manliness with character and honesty. Perhaps nothing so clearly illustrates the degree to which northern and southern ideas of masculinity coincided as the fact that cockfighting was nearly as popular in the antebellum North as it was in the South.

The vast majority of both Southern and Northern whites were viciously racist and antiblack. Abolitionists were just as despised and distrusted in the North as they were in the South. Northerners were often uneasy about freeing blacks as were southern whites. As Freehling writes, "While most Yankees were not fanatical about liberty for blacks, they demanded egalitarian republicanism for whites." 831

With very few exceptions, such as William Lloyd Garrison, antebellum American males, North and South, adhered to the principle of male supremacy. Even the most radical abolitionists, while perhaps willing to permit women to play a role in the reform movements, still believed that it should be a subordinate role. By no means should women be allowed to perform supervisory functions. Indeed virtually every antebellum reform movement was run by men. ${ }^{832}$

\footnotetext{
${ }^{831}$ Freehling, Road to Disunion (vol. 1) 294.

${ }^{832}$ Cott, "Marriage and Women's Citizenship," 1451-1452; Cott, Bonds of Womanhood, 5.
} 
Further complicating matters was the degree to which antebellum American males, in both North and South, associated sectional differences with masculinity. In no respect was this better illustrated than by the competing slavery and free-labor systems. For all of southerners' protestations of paternalist affection, at its core the slave system was based on nothing other than naked power. In this system the master's will was literally law that was brutally enforced through the lash. It takes little imagination to understand how such nearly limitless power, and especially the power to impose themselves sexually upon female slaves, would have enhanced slaveowners' sense of self-esteem and manhood. As previously stated, non-slaveholding males, while they had little economic stake in the slave system, could derive some sense of empowerment from the fact that they could claim superiority over slaves. ${ }^{833}$

Conversely many Northerners strongly related the free-labor ideals of upward mobility and rugged individualism to issues of manhood. This attitude in large part helps account for northern support for the free-soil movement with its emphasis upon economic success or failure as being a measure of manhood. The ability, or lack thereof, to establish an independent household, to father children and more importantly to support them, was a strong indication of manliness and whether or not one 'measured up' as a man. ${ }^{834}$

For both sides to so closely associate sectional issues such as slavery, states rights, and Christianity with masculinity in this way, was to associate what were, on the surface at least,

${ }^{833}$ Freehling, Road to Disunion (vol. 1) 244.

${ }^{834}$ Etcheson, "Manliness," 59-62, 65; Berthoff, "Peasants and Artisans," 582; Cott, "Marriage and Women's Citizenship," 1453; Baker, "Domestication of Politics," 624 ; Rose, "Hoosier Origins," 212; Foner, Free Soil, 13-14, 16-17; Baker, "From Belief into Culture," 538; Basch, "Marriage, Morals, and Politics," 892-894; Margadant, "Political Imaginary", 1466; Creighteon, "Male Breadwinner Family," 323; Foner, Free Soil, 9, 11-12, 23-24; Ditz, "Shipwrecked," 51-80, Berlin \& Gutman, 1195. 
abstract economic and political issues with men's most innate, and primal, sense of themselves. Thus to negotiate with the enemy to give in an inch was not only to surrender their rights and undermine the foundations of their civilization, but also would render them impotent. To defend the system is not only to defend their economic interests, but to defend their identities, both their identities as individuals and especially their identities as men. ${ }^{835}$ For that reason neither North nor South felt that they could back down. Compromise was not only unnecessary but a betrayal. ${ }^{836}$

In addition, the two episodes under consideration, the "Caning of Sumner" and the "Sumter Crisis" were not only important turning points in the sectional crisis but were also closely influenced by antebellum notions of masculinity. The "Caning of Sumner" in addition to being both inspired by and symbolic of the violence then raging in "Bleeding Kansas" and reflective of the increasingly violent nature of sectional politics, was also highly revealing of antebellum gender roles. Both Sumner's speech, and the attack that it provoked, were deliberately calculated to appeal to antebellum notions of manhood.

Brooks, steadfast devotee of Southern honor, felt it was his duty, as a man and a southerner, to defend his kinsman's reputation. Nothing so clearly illustrates the influence of antebellum gender roles on the 'Caning' incident, as the fact that Brooks waited until all women visitors had departed the Senate Chamber before carrying out his attack on Sumner. By the same token, Sumner felt it was his duty, as a northern man, to defend the free soil settlers in Kansas

${ }^{835}$ Freehling, Road to Disunion (vol. 1) 61-63, 180, 226.

${ }^{836}$ Etcheson, "Manliness," 61-2,64, 65, 69-71; Higginbotham, "Martial Spirit," 5; Wyatt-Brown, $\underline{\text { Southern }}$ Honor, 101, 352-62; Crowther, "Holy Honor," 619, 623, 627-629, 632, 633. 
against Senator Butler and his pro-slavery hordes whose ultimate goal, in Sumner's view, was "the rape of a virgin territory." Thus it was their sense of duty, their sense of honor, their sense of manhood, that compelled both Sumner and Brooks to take action against what they considered to be public outrages.

Antebellum concepts of masculinity also had a significant impact upon the Sumter Crisis first through the characters of Presidents Lincoln and Davis, whose actions and attitudes were both influenced by, and were a reflection of, $19^{\text {th }}$ century masculinity. Both men, being products of antebellum American culture, had naturally been influenced by antebellum ideas of masculinity all their lives and to a considerable degree embraced those ideas. But of greater importance was the influence exerted by antebellum ideas of manhood on the decision-making process of North and South. In both regions, political leaders were expected to conform to what they considered proper standards of male behavior such as candidness, intelligence, physical strength, and courage. And since only men could vote, it was only natural that these ideas would have strongly influenced Presidents Lincoln and Davis.

In addition, regional prejudices also strongly influenced the two presidents. Davis was driven toward war by political pressures that at times must have seemed overwhelming. Many southerners seemed eager for war, motivated by a desire to teach a lesson to the Yankees and by dreams of a vast 'slave empire' that might eventually embrace not only the South but the entire western Hemisphere. Lincoln, for his part, felt pressure from northerners such as Frank Blair who were tired of kow-towing to the arrogant "cotton snobs" and who demanded that Lincoln strike a blow. 
It is important to point out that for similar reasons neither Davis nor Lincoln desired or expected war. But those very expectations made war inevitable. Davis did not expect a war because, like many southerners, he had a stereotypical view of Northerners as cowards, clerks, and effete intellectuals with no concept of honor. These views led Davis to believe that the North would not fight and if they did fight they would certainly prove no match for Southern manhood. Lincoln similarly did not expect war. Like many northerners Lincoln thought that southerners were full of bluster, short on courage and he always believed that Southern Unionist sentiment was stronger than it actually was. ${ }^{837}$ So while neither side actively sought war, their misperceptions of the other combined with their concepts of masculinity to make war unavoidable. North and South, each secure in the belief that the other would back down by acting with undue belligerence deliberately provoked their opponents into a confrontation.

One of the main goals of this project is to reexamine Civil War historiography, and especially the issue of whether the war was avoidable or if it was an "Irrepressible Conflict."838 By illustrating the degree to which northern and southern ideas of masculinity differed and the degree to which masculinity was related to various sectional issues, valuable insight has been provided into this issue and into the two fundamental questions of Civil War historiography: why the South seceded and why secession led to war? Southerners, whose sense of manhood was strongly tied to the plantation slavery system, were so unnerved by the election of a president

\footnotetext{
${ }^{837}$ Davis perhaps had good reason to believe that the North would not resist secession. Many Northerners, including New York City Mayor Fernando Wood, were of the opinion that the government should allow "erring sisters to depart in peace' and were quite vocal in expressing those opinions. Stephen V. Ash, "Poor Whites in the Occupied South, 1861-1865," The Journal of Southern History, Vo.l. 57, Number 1 (Feb. 1991), 47.

${ }^{838}$ Allan Nevins, William W. Freehling, “The Civil War: Repressible or Irrepressible?” Interpretations of American History Patterns and Perspectives, Volume I: Through Reconstruction, Francis G. Couvares, Martha Saxton, Gerald N. Grob, George Athan Billias eds., (New York: The Free Press, 2000), 339.
} 
committed, as they thought, to abolitionism that they preferred to break up the Union rather than submit to that emasculation.

Furthermore the fact that both North and South equated manhood with firmness and dedication to principle meant that neither side was willing to compromise. Add to all this the aggressive nature of antebellum masculinity, its influence on the decision making process of Presidents Lincoln and Davis, the fact that the voting public was composed entirely of white males, and the deep and bitter divisions over economic, political and social issues, and the outbreak of war in 1861 does indeed seem unavoidable. ${ }^{839}$

This study, by focusing on the key episodes of the "Caning of Sumner" and the Sumter Crisis and specifically the role of masculinity in these episodes, has also shown that sectionalism and the outbreak of war were in fact both part of a single process--the process of disunion. While sectionalism did not begin with the "Caning of Sumner," the "Caning" does represent an important turning point in North-South relations. More specifically it marks the beginning of a period of dramatically increasing sectional tensions. When reading contemporary accounts of the attack one is struck by the outrage that the incident provoked. Although this was not the first time that political violence had occurred, still there was a strong sense that a line had been crossed and that civility was breaking down. In essence then the "Caning" was but the first of a series of events, that represented a period of escalating sectional tensions and escalating political violence, that continued through "Bleeding Kansas," the Dred Scott decision, the LincolnDouglass debates, John Brown's Raid, the Election of 1860 and which finally reached critical mass with the secession of the Lower South.

${ }^{839}$ Olsen, 170, 193, 195; Genovese, 32-33, 102-105; Morgan, 35; Sydnor, 5-6. 
The Sumter Crisis then was the final culmination of a process that had begun five years before with the Sumner attack. Manhood exacerbated this process. At each stage of this process, when North and South could have resolved their differences, masculinity prevented them from doing so. Blinded by their prejudices, driven by chauvinistic delusions of grandeur, and justified by an inflated sense of moral superiority, North and South marched ever closer to the abyss.

This work also goes a long way toward resolving one the oldest debates in Civil War historiography: whether it was the differences or the similarities between North and South that caused the war. Many historians, such as Edward Pessen, argue that North and South "shared the same language, the same Constitution, the same legal system, the same commitment to republican political institutions, an interconnected economy, the same predominantly Protestant religion and British ethnic heritage." From this Pessen concludes that the "concept of a separate and unique South existed in hearts and minds" but no where else. ${ }^{840}$

James McPherson differs strongly with Pessen's position, instead arguing that "the problem with this argument, of course, is that it could be used to prove many obviously different societies to be similar." ${ }^{841}$ McPherson cites such examples as "France and Germany in 1914 and 1932; England and France during the $18^{\text {th }}$ century; Turkey and Russia during the $19^{\text {th }}$ century . . .And so on." ${ }^{842}$ The other problem with Pessen's argument is that it begs the question: if inter-

\footnotetext{
${ }^{840}$ James McPherson, "The Differences between the Antebellum North and South" Major Problems Perman, ed., 22, 23, 24; Edward Pessen, "The Similarities between the Antebellum North and South" Major Problems Perman, ed., 11-12 reprinted from Edward Pessen, "How Different were the Antebellum North and South?" American Historical Review Vol. 85, No. 5, (December 1980) 1119-1149.

${ }^{841}$ McPherson, "Differences,” 23.

${ }^{842}$ McPherson, "Differences," 23.
} 
sectional differences did not drive North and South to war, what did? Pessen and other advocates of the "objective similarity" argument while they, presumably, would have us believe that the cause lay in some aspect of similarity, are suspiciously unclear on this point.

Antebellum masculinity provides a means of resolving this apparent dilemma. Indeed it has already been abundantly demonstrated that North and South were similar in some respects and dissimilar in other respects. But as antebellum masculinity also illustrates, it was not just the fact that North and South shared certain characteristics and differed on others but their specific similarities and dissimilarities: their propensity for violence, the tendency to view their sectional counterparts as unmanly and the fact that they associated so many of the issues dividing North and South with masculinity, provided a powerful impetus for war.

In addition to the insights it provides on the causes of the war, masculinity also played a significant role in the war itself and even helps explain why the war turned out the way it did. In other words many of the same factors that led the South to secede from the Union also led to its downfall. As pointed out by Gerald Linderman in Embattled Courage, and Grady McWhiney and Perry D. Jamieson in Attack and Die: Civil War Military Tactics and the Southern Heritage, officers during the Civil War subscribed to the theory that battles were won by attacking the enemy and destroying him. In part this was a result of training. As West Point graduates, officers on both sides read the standard military texts of the time, and had studied the works of Antoine Jomini, all of which strongly emphasized the importance of the strategic offensive. But it was also a matter of culture. Even if they had never read Jomini, the aggressive nature of antebellum masculinity would have predisposed these officers to take the offensive. ${ }^{843}$

${ }^{843}$ Grady McWhiney and Perry D. Jamieson, Attack and Die: Civil War Military Tactics and the Southern 
Antebellum masculinity not only made these men more inclined toward offensive warfare but also caused them to cling to the offensive long after the advent of new weapons-specifically the rifled musket-had rendered such tactics obsolete. This of course largely accounts for the high casualty rate of Civil War battles but it also accounts, in large measure, for the Confederacy's defeat. Because southern officers, including Robert E. Lee, were more inclined toward the offensive than were their northern counterparts the Confederacy sacrificed thousands of lives in useless assaults, such as Pickett's Charge, that accomplished little other than to cripple their armies.

Union generals also lost thousands of men in similarly fruitless assaults at Fredericksburg, Cold Harbor, and elsewhere, but the North could replace their losses, while the South could not. Also, for the most part Union generals, specifically Grant and Sherman, learned from their mistakes and changed their tactics to conform with the new realities of war. Southerners on the other hand seemed less willing or less able to part with the old ways; they continued to cling to the idea of chivalrous warfare, just as they clung to slavery, long after both had become liabilities.

Antebellum masculinity also influenced the war's conduct through the decision to accept African-Americans into the Union army. Given the era's emphasis upon 'civic virtue' and the importance attached to the defense of the republic as an obligation of citizenship, if blacks were ever to be accepted as citizens it was essential that they join the struggle Before blacks could be accepted as citizens they first had to be accepted as men; before they could be accepted as men, they had to be accepted as soldiers, and before they could be accepted as soldiers they would 
have to prove their courage on the battlefield. This fact was not lost on Black leaders, like Frederick Douglass, and in large part drove their insistence that Blacks be allowed to serve. While many northerners were no more willing than Confederates to accept blacks as soldiers or as citizens, still the Lincoln Administration's decision to accept black volunteers was a signal event in the history of American freedom as well as a significant factor in southern defeat. ${ }^{844}$

But at the same time care should be taken not to overemphasize the role of masculinity in bringing on the Civil War or to see masculinity as being the sole casus belli. The fact that Brooks, Sumner, Lincoln and Davis were all products of antebellum masculinity and were all influenced by its ideals of manhood, yet none of them fully lived up to those ideals (it is doubtful that anyone ever did) clearly illustrates that while masculinity's influence over antebellum males was strong it was not absolute. Indeed there are several questions, such as why the states of the Upper South hesitated to secede and why the Old Northwest, despite the large numbers of Upland Southerners living there, chose to remain loyal to the Union, that masculinity alone cannot answer.

But as was stated at the outset, it is not my contention that masculinity alone brought on the war, nor is it to deny the role of political and economic factors. Certainly North and South were bitterly divided over issues such as states' rights, slavery, protective tariffs, and economic development, but as Donald rightly pointed out in An Excess of Democracy, such issues by themselves were not sufficiently divisive to bring about conflict. Masculinity was not the sole cause of the war, but it was the key factor that made war inevitable.

\footnotetext{
${ }^{844}$ Berthoff, "Peasants and Artisans," 582 \& 585; Cott, "Marriage and Women's Citizenship," 1453; Baker, "From Belief into Culture," 542; Olsen, 121, 126, 172-74; Etcheson, "Manliness," 62, 64; Crowther, "Holy Honor," 620.
} 
One final question to which masculinity provides at least a partial answer is the matter of why the war did not occur until 1861. In this instance the answer is to be found in the persons of Lincoln and Davis. They were the catalysts that brought about the war. While both men were deeply influenced by antebellum masculinity in their outlook and their decision making, at the same time the importance of their individual personalities and characters cannot be discounted. One is forced to acknowledge the "conventional wisdom" of historians that Lincoln was a more astute politician than Davis. Certainly, both social and political pressures and his own inclinations predisposed Davis to fire the first shot. At the same time it should also be noted that Lincoln's perceptiveness, his intelligence and superior political skills enabled him to realize that Davis could be goaded into doing so.

The potential implications of this study are far-reaching and extend well beyond the realm of Civil War historiography. History contains several episodes, such as the Cuban Missile Crisis and the outbreak of the First World War, which were similarly influenced by contemporary notions of masculinity. Indeed it can be reasonably argued that in large measure masculinity is the engine that has driven much of the process of history. But again care must be taken to not draw conclusions too broadly. Just as it is a mistake to think that masculinity alone caused the Civil War, it would also be a mistake to attribute all of humanity's bloody legacy of violence to the fact that men are unthinking, testosterone-driven, brutes.

From there it is a very short leap to the conclusion that if nations only stopped following men, there would be no more war. In the first place, history provides plenty of examples, such as Catherine the Great, Queen Elizabeth I, Margaret Thatcher, Golda Meir, of female heads-of-state 
who were as aggressively militaristic as any man. ${ }^{845}$ One could also argue that had Lincoln's predecessors, especially the hapless James Buchanan, been less accommodating and shown more "backbone" in dealing with the South, the Civil War might have been avoided. While further work needs to be done in this field the utility of masculinity, as a conceptual framework through which to better understand the process of history, is only now becoming apparent.

${ }^{845}$ Admittedly one could argue that in all of these cases, especially that of Golda Meir, the fact that they were surrounded by aggressive and dangerous male antagonists may have forced them to act more aggressively in order to avoid being seen as weak, helpless, women. 


\section{BIBLIOGRAPHY:}

\section{PRIMARY SOURCES:}

\section{BOOKS:}

Adams, Henry. The Education of Henry Adams: An Autobiography. (New York: The Modern Library, 1999.

Bates, Edward. The Diary of Edward Bates, 1859-1866. ed. Howard K. Beale. Washington D.C.: U.S. Government Printing Office, 1933.

Browning, Orville, H. The Diary of Orville Hickman Browning, eds. Theodore C. Pease and James G. Randall. 2 vols. Springfield: Illinois State Historical Library, 1925-33.

Castiglione, Baldasar. The Book of the Courtier. ed. and trans. George Bull. London: Penguin Books, 1967.

Chesnut, Mary Boykin. Mary Chesnut's Civil War. ed. C. Vann Woodward. New Haven, Conn.: Yale University Press, 1981.

Congdon, Charles T. Reminisces of a Journalist. Boston: James R. Osgood and Company; 1880.

Warwich, John. ed. Life and Reminiscences of Jefferson Davis by Distinguished men of his time. Baltimore: R.H. Woodward \& Company, 1890.

Davis, Jefferson. Jefferson Davis, Private Letters, 1823-1889. ed. Hudson Strode. New York: Harcourt, Brace, \& World, Inc., 1966.

. The Rise and Fall of the Confederate Government. New York: Thomas Yoseleff, 1958.

. President, Confederate States of America.. The Messages and Papers of Jefferson Davis and the Confederacy, including diplomatic correspondence: 1861-1865. 2 vols. ed. and comp. James P. Richardson. New York: Chelsea House-Robert Hector Publishers, 1966.

. The Papers of Jefferson Davis. eds. Haskell M. Monroe, James T. McIntosh, Lynda Lasswell Crist and Mary Seaton Dix. 10 Vols. Baton Rouge: Louisiana State University Press, 1971-1999.

Dumon, Dwight L. ed. Southern Editorials on Secession. New York: The Century Company, 1931. 
Fox, Gustavus Vasa. Confidential Correspondence of Gustavus Vasa Fox, eds. Robert Means Thompson and Richard Wainwright. 2 vols. New York: Printed for the Naval History Society by the Devinne, Press, 1918-1919.

Gobright, Arthur Lawrence Augustus. Recollections of Men and Things at Washington, during the third of a century. Philadelphia: Claxton, Denisen and Heffelfinger; Washington, W.H and O.H. Morrison, 1869.

Herndon, William H. and Jesse W. Weik. Herndon's Lincoln: The True Story of a Great Life. 3 vols. Chicago: Belford-Clarke, 1890.

Jones, John B. A Rebel War Clerk's Diary. ed. Earl Schenck Meers. New York: A.S. Barnes \& Company, 1961.

Lincoln, Abraham. An Autobiography of Abraham Lincoln, Consisting of the Personal Portions of his Letter, Speeches and Conversations. comp. and annot. Nathaniel Wright Stephenson. Indianapolis: The Bobbs-Merrill Company, 1926.

. The Collected Works of Abraham Lincoln. 9 vols. eds. Roy P. Basler, Marion Delores Pratt, and Lloyd A. Dunlap. New Brunswick, New Jersey: Rutgers University Press in association with the Abraham Lincoln Association, 1953-55. . Lincoln: Selected Speeches and Writings. New York: Vintage Books, 1992.

Long, Armistead Lindsay. Memoirs of Robert E. Lee: his military and personal history, embracing a large amount of information hitherto unpublished, by A.L. Long, together with incidents relating to his private life subsequent to the war, collected and edted with the assistance of Marcus J. Wright. Charlottesville: J.H. Stoddart and Company, 1886.

Lull, Roman. The Book of the Order of Chivalry. trans. William Caxton. ed. A.T.P. Byles. Early English Text Society o.s. 168. London: Oxford University Press, 1926.

Nicolay, John G. and John Hay. Abraham Lincoln: A History. 10 vols. New York: Century, 1890.

Perkins, Howard Cecil. ed. Northern Editorials on Secession. 2 vols. Gloucester Mass: Peter Smith, 1964.

Ruffin, Edmund. The Diary of Edmund Ruffin. 2 vols. ed. William K. Scarborough. Baton Rouge: Louisiana State University Press, 1972.

Seward, William A., The Works of William H. Seward. ed. George Baker. 5 vols. Boston, Mass., New York: Houghton, Mifflin \& Co., 1884.

Strong, George Templeton. The Diary of George Templeton Strong. eds. Allan Nevins and Milton Halsey Thomas. 4 vols. New York: The Macmillan Co.; 1952. 
Diary of the Civil War, 1860-1865. ed. Allan Nevins. New York: The Macmillan Company, 1962.

Sumner, Charles. Charles Sumner: His Complete Works. 20 vols. Boston: Lee and Shepard, 1900.

Underwood, Robert and Clarence Clough Buel, eds. Battles and Leaders of the Civil War, Being for the most part contributions by Union and Confederate Officers, based upon the "Century War Series." 4 vols. New York: The Century Co., 1884-1888.

The War of the Rebellion: A Compilation of the Official Records of the Union and Confederate Armies. 130 vols. Washington D.C.: Government Printing Office, 1880.

Wells, Gideon. Diary of Gideon Welles, Secretary of the Navy Under Lincoln and Johnson (In three Volumes). ed. Howard K. Beale. New York: W.W. Norton \& Company, 1960.

Wilson, Douglas L. and Rodney O. Davis. eds. Herndon's Informants: Letters, Interviews and Statements about Abraham Lincoln, (Urbana: University of Illinois Press, 1998).

\section{JOURNAL ARTICLES:}

"Art. V.-Hon. Preston S. Brooks-Speeches of the Honorable Preston S. Brooks, and Proceedings of Congress on the occasion of his death, Southern Quarterly Review 2, No. 2 (February 1857) 349-370.

\section{NEWSPAPERS:}

Boston Advertiser. 26 May 1856-27 May 1856.

Boston Bee. 23 May, 1856.

Boston Courier. 23 May 1856.

Boston Post. April 16, 1861.

Brooklyn Daily Eagle. April 15, 1861.

Charleston Mercury. 6, 7, 16 December 1844; 28, 29 May 1856.

Chatfield (Minn.) Republican. 16 April 1861.

Chicago Daily Tribune. 18 December 1860.

Columbia South Carolinian, 27, 28 May 1856. 
Commercial Advertiser. (Buffalo) 1 April 1861.

Daily American Star. (Mexico City, Mexico) 9 November 1847.

Daily Atlas and Bee. (Boston) 3 December 1860 .

Daily Chicago Times. 10 December 1860.

Daily Commercial. (Cincinnati) 20 February 1861.

Daily Enquirer. (Cincinnati) 23 May 1856.

Daily Gazette. (Cincinnati) 14 January 1861.

Daily Green Mountain Freeman. (Montpelier, Vt.) 17 May 1861.

Daily National Democrat. (Cleveland) 20 November 1860.

Daily Press. (Cincinnati) 1 February 11861.

Daily Register (Grand Rapids) 18 April 1861.

Daily Wisconsin. (Milwaukee) 18 January 1861.

Edgefield (S.C.) Advertiser. 28 May 1856; 1936.

Eastern Argus. (Portland, Maine) 15 April 1861.

Evening Journal. (Albany, New York) 23 May 1856.

Laurensville, (S.C.) Herald. 6 June 1856.

Liberator (Boston) 6 June 1856.

Montpelier (Vt.) Patriot and State Gazette. 13 June 1856

Morning Express, (Buffalo, New York) 24 May 1856-December 24, 1860.

New York Commercial Advertiser. 2 January 1861.

Nashville Republican Banner and Nashville Whig. 27 May 1856.

National Era. (Washington, D.C.) 19 January 1854.

New York Daily News. 25 December 1860.

New York Evening Post. 12 March1861.

New York Times. 7 December 1860; 15 April 1861. 
New York Tribune. 21, 23 May, 1856.

Patriot and Mountaineer. (Greenville, South Carolina) 29 May 1856.

Pittsburgh Gazette. 24 May 1856.

Pittsburgh Post. 15 April 151861.

Portland Advertiser. 23 May 1856.

Provincial Freeman.(Chatham, Canada) 14 February 1857.

Raleigh Register. 6 June 1856.

Richmond Enquirer. 30 May 1856; 18 December 1860.

Rochester (N.Y.) Democrat. 3 September 1857.

Spartanburg (S.C.) Spartan. 29 May 1856.

Spectator. (Stauton, Va. ) 30 April 1861.

States and Union. (Washington, D.C.) 15 April 1861.

Union Democrat. (Manchester, N.H.) 19 February 1861.

Yorkville (S.C.) Enquirer, May 29, 1856,

\section{GOVERNMENT DOCUMENTS:}

United States Government. Congress of the United States. Congressional Globe. $34^{\text {th }}$ Congress. First Session, Second Session Third Session. 1855-57.

United States Government. Congress of the United States. United States House of Representatives. Alleged Assault Upon Senator Sumner House Report No. 182. 34th Congress. First Session. 1856.

United States Government. Congress of the United States. United States House of Representatives. Charles Sumner, "Testimony to House Select Committee." 1 July 1856.

United States Government. Congress of the United States. United States Senate. Journal of the Senate of the United States of America, 1789-1873. 29 January 1857.

United States Government. Executive Office of the President. Executive Document No. 8. "Message from the President." 30 ${ }^{\text {th }}$ Congress. First Session. 1848. 


\section{SPEECHES:}

Brooks, Preston. "Preston S. Brooks of South Carolina on the Sumner Assault" House of Representatives. 14 July 1856.

Donald, David Herbert. An Excess of Democracy: The American Civil War and the Social Process. An Inaugural Lecture Delivered Before the University of Oxford on 2 May 1960. Oxford: The Clarendon Press, 1960.

Sumner, Charles. "The Crime Against Kansas:" Speech of Charles Sumner of Massachusetts, In the Senate of the United States, May 18, 1856.

\section{WEBSITES:}

Accessible Archives Inc. Primary Source Material from $18^{\text {th }}$ and $19^{\text {th }}$ Century Periodicals. Accessible Archives, Inc. Malvern, Pa.< http://www.accessible.com/ accessible/text/freedom.htm>

"A Century of Lawmaking for a new nation: U.S. Congressional Documents and Debates, 17741783." American Memory. Library of Congress Website. $<$ http://lcweb2.loc.gov $>$.

Making of America Website. University of Michigan. $<$ http://www.hti.umich.edu/t/text.gifcvtdir /acp1141.3-02.002/03480348.tifs.gif>.

"Secession Era Editorials Project." Furman Online Primary Source Collection. Furman University History Department. <http://history.furman.edu/benson.docs.>

The Valley of the Shadow Project: Two Communities in the American Civil War. Department of History. University of Virginia. Copyright 1993-2003, All Rights Reserved, Edward L. Ayers. $\leq$ http://valley.vcdh,virginia.edu. $>$

\section{SECONDARY SOURCES:}

BOOKS:

Allen, Felicity. Jefferson Davis: Unconquerable Heart. Columbia: University of Missouri Press, 1999.

Allen, James S. Reconstruction: The Battle for Democracy 1865-1876. New York: Charles Scribners's Sons, 1937.

The American Man. Englewood Cliffs, N.J.: Prentice-Hall, 1980. 
Barker-Benfield, G.J. The Horrors of the Half-Known Life: Male Attitudes toward Women and Sexuality in Nineteenth-Century America. New York: Harper and Row, 1976.

Barney, William L. The Road to Secession: A New Perspective on the Old South. New York: Praeger, 1972.

Bates, Edward. The Diary of Edward Bates, 1859-1866. ed. Howard K. Beale. Washington D.C.: U.S. Government Printing Office, 1933.

Bauer, K. Jack. The Mexican War: 1846-1848. New York: MacMillan Publishing, 1974.

Beard, Charles A. and Mary R. Beard. The Rise of American Civilization. 2 vols. New York, 1927.

Brod, Harry ed. The Making of Masculinities. Boston: Allen \& Unwin, 1987.

Carnes, Mark C. and Clyde Griffen, eds. Meanings for Manhood: Constructions of Masculinity in Victorian America. Chicago: University of Chicago Press, 1990.

Cash, W.J. The Mind of the South. New York: Alfred A. Knopf, 1941.

Channing, Edward. A History of the United States. 6 vols. New York: 1905-25.

Clinton, Catherine. The Plantation Mistress: Women's World in the Old South. New York: Pantheon Books, 1982.

Cooper, William J. Jr. Jefferson Davis, American. New York: Alfred A. Knopf, 2000.

Cott, Nancy F. The Bonds of Womanhood, "Woman's Sphere" in New England, 1780-1835. New Haven: Yale University Press, 1977.

Couvares, Francis G., Martha Saxton, Gerald N. Grob, and George Athan Billias, eds. Interpretations of American History Patterns and Perspectives, Volume I: Through Reconstruction. New York: The Free Press, 2000.

Craven, Avery. The Coming of the Civil War. New York: Charles Scribner's Sons, 1942. . The Irrepressible Conflict 1830-1861. Baton Rouge: Louisiana State University Press, 1939.

Current, Richard N. Lincoln and the First Shot. Philadelphia: J.B. Lippincott, 1963.

Davis, William C. Jefferson Davis: The Man and his hour. New York: Harper-Collins, 1991. 
Degler, Carl N. Neither Black nor White: Slavery and Race Relations in Brazil and the United States. New York: Macmillan Publishing Co., 1971.

Detzer, David. Allegiance: Fort Sumter, Charleston, and the Beginning of the Civil War. New York: Harcourt, Inc., 2001.

Dirck, Brian R. Lincoln \& Davis, Imagining America, 1809-1865. Lawrence, Kansas: University Press of Kansas, 2001.

Donald, David Herbert. Charles Sumner and the Coming of the Civil War. New York: Alfred A. Knopf, 1960. . Lincoln. New York: Touchstone Books: 1995.

Eaton, Clement. Jefferson Davis. New York: The Free Press, 1977.

Etcheson, Nicole. Bleeding Kansas, Contested Liberty in the Civil War Era. Lawrence, Kansas: The University of Kansas Press, 2004.

Frazer, John. America and the Patterns of Chivalry. Cambridge: Cambridge University Press, 1982.

Freehling, William W. The Road to Disunion: Secessionists at Bay, 1776-1854. New York: Oxford University Press, 1990.

Genovese, Eugene D. The Political Economy of Slavery. New York Vintage Books 1965. . The World The Slaveholders Made: Two essays in interpretation. Middletown, Conn.: Wesleyan University Press, 1988.

Gilmore, David. Manhood in the Making: Cultural Concepts of Masculinity. New Haven: Yale University Press, 1990.

Goldberg, Steven. The Inevitability of Patriarchy. New York: Morrow, 1973.

Hanchett, William. Out of the Wilderness: The Life of Abraham Lincoln. Urbana: The University of Illinois Press, 1994.

Hattaway, Herman, and Richard E. Beringer. Jefferson Davis: Confederate President. Lawrence, Kansas: University Press of Kansas, 2002.

Hendrick, Burton J. Lincoln's War Cabinet. Gloucester, Mass.: Peter Smith, 1965.

Hoag, Robert Selph. The Story of the Mexican War. New York: The Bobbs-Merrill Co., 1950. 
Holt, Michael F. The Political Crisis of the 1850s. New York: W.W. Norton \& Company, 1978.

Isaac, Rhys. The Transformation of Virginia, 1740-1790. Published For the Institute of Early American History and Culture Williamsburg, Va. Chapel Hill: University of North Carolina Press: 1982. Johannsen, Robert N. Stephen A. Douglas. New York: Oxford University Press, 1973.

Jordan, Winthrop D. White Over Black: American Attitudes Toward the Negro, 1550-1812. Chapel Hill: University of North Carolina Press, 1968.

Josephson, Matthew. The Robber Barons: The Great American Capitalists 1861-1901. New York, 1934.

Kennedy, Beverly. Knighthood in the Morte D’Arthur. Woodbridge, Suffolk, U.K.; Rochester,: D.S. Brewer, 1992.

Klein, Maury. Days of Defiance: Sumter, Secession and the Coming of the Civil War. New York: Alfred A. Knopf, 1997.

Kolchin, Peter. American Slavery 1619-1877. New York: Hill and Wang. 1993.

Kraditor, Aileen S. Up from the Pedestal: Selected Writings in the History of American Feminism. Chicago: Quadrangle Books, 1968.

Lerner, Gerda. The Creation of Patriarchy. New York: Oxford University Press, 1986.

Leverenz, David. Manhood and the American Renaissance. Ithaca, New York: Cornell University Press, 1989.

Maccoby, Eleanor and Carol Jacklin. The Psychology of Sex Differences. Stanford: Stanford University Press, 1974.

Malory, Sir Thomas. Le Morte D’Arthur. London: J.M. Dent; New York: E.P. Dutton, 1947.

Meredith, Roy. Storm over Sumter: The Opening Engagement of the Civil War. New York: Simon and Schuster, 1957.

Morgan, Edmund S. American Slavery, American Freedom, The Ordeal of Colonial Virginia. New York: W. W. Norton \& Company, Inc, 1975.

McCurry, Stephanie. Masters of Small Worlds: Yeoman Households, Gender Relations, \& the Political Culture of the Antebellum South Carolina Low Country. New York: Oxford University Press, 1995. 
McPherson, James M. Battle Cry of Freedom: The Civil War Era. New York: Ballantine Books, 1988.

. Ordeal by Fire: The Civil War and Reconstruction. Boston: McGraw-Hill, 2001

McPherson, James and William J. Cooper, eds. Writing the Civil War: The Quest to Understand. Columbia, S.C.: University of South Carolina Press, 1998.

McWhiney, Grady and Perry D. Jamieson. Attack and Die: Civil War Military Tactics and the Southern Heritage. Montgomery, Alabama: The University of Alabama Press, 1982.

Nevins, Allan. Ordeal of the Union 2 vols Volume II: A House Dividing, 1852-1857. New York: Charles Scribners' Sons, 1947.

Nichols, Jack. Men's Liberation: A New Definition of Masculinity. New York, Penguin Books, 1975.

Nichols, Roy F. The Disruption of American Democracy. New York: Macmillan Col., 1948.

Norton, Mary Beth. Founding Mothers and Fathers: Gendered Power and the Forming of American Society. New York: A. A. Knopf, 1996.

Oates, Stephen B. With Malice Toward None: The Life of Abraham Lincoln. New York: Mentor Books, 1978.

Olsen, Christopher J. Political Culture and Secession in Mississippi: Masculinity, Honor, and the — Antiparty Tradition, 1830-1860. Oxford: Oxford University Press, 2000.

Ownby, Ted. Subduing Satan: Religion, Recreation, and Manhood in the Rural South, 18651920. Chapel Hill: The University of North Carolina Press, 1990.

Perman, Michael, ed. Major Problems in the Civil War and Reconstruction. Boston: HoughtonMifflin, 1998.

Pleck, Joseph H. The Myth of Masculinity. Cambridge: MIT Press, 1981. and Jack Sawyer, eds. Men and Masculinity. Englewood Cliffs, N.J.: 1974.

Pollard, Edward A. The Lost Cause: A New Southern History of the War of the Confederates. New York: Treat, 1866.

Potter, David M. The Impending Crisis: 1848-1861. comp. and ed. Don E. Fehrenbacher. New York: Harper \& Row, 1976. 
Pressly, Thomas J. Americans Interpret Their Civil War. New York: Free Press, 1954.

Pugh, David G. Sons of Liberty: The Masculine Mind in Nineteenth Century America. Westport, Conn.: Greenwood Press, 1983.

Rhodes, James Ford. Lectures on the American Civil War delivered before the University of Oxford in Easter and Trinity terms. New York: The MacMillan Company, 1913.

Ryan, Mary P. Cradle of the Middle Class: The Family in Oneida County, New York, 17901865. Cambridge: Cambridge University Press, 1981.

Schaff, Morris. Jefferson Davis: His Life and Personality. Boston: John W. Luce and Company, 1922.

Scott, Ann Firor. The Southern Lady: From Pedestal to Politics, 1830-1930. Chicago: University of Chicago Press, 1970.

Sewell, Richard H. A House Divided: Sectionalism and the Civil War 1848-1865. Baltimore: Johns Hopkins University Press, 1988.

Shorter, Edward. The Making of the Modern Family. New York: Basic Books, 1975.

Silbey, Joel H. The Partisan Imperative: The Dynamics of American Politics Before the Civil War. New York: Oxford University, 1985.

. The Shrine of Party: Congressional Voting Behavior, 1841-1852. Pittsburgh: University of Pittsburgh, Press, 1967.

Simon, Algie M. Class Struggles in America. Chicago: C.H. Kerr, 1906.

Smith, James Martin, ed. Seventeenth-Century America: Essays in Colonial History. Chapel Hill, N.C.: University of North Carolina Press, 1959.

Spruill, Julia Cherry. Women's Life \& Work in the Southern Colonies. New York: W.W. Norton \& Company, 1972.

Stampp, Kenneth M. And the War Came: The North and the Secession Crisis, 1860-1861. Baton Rouge: Louisiana State University Press, 1950. . ed. The Causes of the Civil War. Englewood Hills, N.J.: Prentice-Hall, Inc, 1959. . The Peculiar Institution: Slavery in the Antebellum South. New York: Vintage Books, 1989. 
. ed. The Imperiled Union: Essays on the Background of the Civil War. New York: Oxford: Oxford University Press, 1980.

Stearns, Peter N. Be A Man! Males in Modern Society. New York: Holmes \& Meier Publishers, Inc., 1979.

Sydnor, Charles S. Gentleman Freeholders: Political Practices in Washington's Virginia. Chapel Hill: The University of North Carolina Press, 1952.

Twelve Southerners: I'll Take My Stand, the South and the Agrarian Tradition. New York.: Harper, 1930.

Van Deusen, Glyndon G. William Henry Seward. New York: Oxford University Press, 1967.

Vinovkis, Maris A. Ed. Toward a Social History of the American Civil War: Exploratory Essays. Cambridge, Mass.: Harvard University Press, 1990.

Washburn, Wilcomb E. The Governor and The Rebel: A History of Bacon's Rebellion in Virginia. Chapel Hill: The University of North Carolina Press 1957.

Webb, Stephen Saunders. 1676: The End of American Independence. Syracuse: Syracuse University Press, 1995.

. Lord Churchill's Coup: The Anglo-American Empire and the Glorious Revolution Reconsidered. New York: Alfred A. Knopf, 1995.

Wertenbaker, Thomas J. Patrician and Plebeian in Virginia or the Origin and Development of the Social Classes of the Old Dominion. New York: Russell \& Russell, 1959.

Wilentz, Sean. Chants Democratic: New York City and the Rise of the American Working Class, 1788-1850. New York: Oxford University Press, 1984.

Wilkinson, Rupert. American Tough: The Tough-Guy Tradition and American Character. New York: Harper and Row, 1984.

Wilson, Henry. History of the Rise and Fall of the Slave Power in America. 3 vols. Boston, 1872-77.

Wright, Louis B. First Gentlemen of Virginia. San Marino, California: The Huntington Library, 1940.

Wyatt-Brown, Bertram. Southern Honor: Ethics and Behavior in the Old South. Oxford: Oxford University Press, 1982. 


\section{JOURNAL ARTICLES:}

Ash, Stephen V. "Poor Whites in the Occupied South, 1861-1865." Journal of Southern History 57, No. 1 (February, 1991): 39-62

Bailey, Fred A. "Class and Tennessee's Confederate Generation." Journal of Southern History 51, No. 1 (February, 1985): 31-68.

Baker, Jean. "From Belief into Culture: Republicanism in the Antebellum North." American Quarterly 37, No. 4 (Autumn, 1985): 532-550.

Baker, Paula. "The Domestication of Politics: Women and American Political Society, 17801920" American Historical Review 89, No. 3 (June 1984): 620-647.

Baptist, Edward E. "Accidental Ethnography in an Antebellum Southern Newspaper: Snell's Homecoming Festival.” Jounral of Southern Hisotry 84, No. 4 (March, 1998): 1355-1383.

Basch, Norma. "Marriage, Morals, and Politics in the Election of 1828." Journal of American History 80, No. 3 (December, 1993): 890-918.

Bederman, Gail. “'The Women Have Had Charge of the Church Work Long Enough': The Men and Religion Forward Movement of 1911-1912 and the Masculinization of Middle Class Protestantism." American Quarterly 41, No. 3 (September, 1989): 432-465.

Bellows, Donald. "A Study of British Conservative Reaction to the American Civil War." Journal of Southern History 51, No. 4 (November, 1985): 505-526.

Berlin, Ira and Herbert G. Gutman "Natives and Immigrants, Freemen and Slaves: Urban Working Men in the Antebellum American South." American Historical Review 88, No. 5 (December, 1983): 1175-1200.

Berthoff, Rowland. "Peasants and Artisans, Puritans and Republicans: Personal Liberty and Communal Equality in American History." The Journal of American History 69, No. 3 (December 1982): 579-598..

Breen, Timothy Hall. "Structuring Provincial Imagination in the Rhetoric and Experience of Social Change in Eighteenth Century New England." American Historical Review 103, No. 5 (December, 1998): 1411-1439..

Brown, Gillian. "Getting in the Kitchen with Dinah: Domestic Politics in Uncle Tom's Cabin." American Quarterly 56, No. 4, (Autumn, 1989): 503-523. 
Butsch, Richard. "Bowery B'hoys and Matinee Ladies: The Re-gendering of Nineteenth-Century American Theater Audiences." American Quarterly 46, No. 3 (September, 1994): 374405..

Campbell, James E. "Sumner-Brooks-Burlingame, or, The Last of the Great Challenges." Ohio Archeological and Historical Quarterly 34 (1925): 435-73.

Clark, Anna. "The Chevalier d'Eon and Wilkes: Masculinity and Politics in the Eighteenth Century." Eighteenth Century Studies 32, No. 1 (1998): 19-48.

Cott, Nancy F. “Marriage and Women's Citizenship in the United States, 1830-1934” American Historical Review 103, No. 5 (December, 1998): 1440-1474.

Crawford, Martin. "Political Society in the Southern Mountain Community: Ashe County, North Carolina, 1850-1861” Journal of Southern History 55, No 3 (August, 1989): 373-390.

Creighton, Colin. "The Rise of the Male Breadwinner Family: A Reappraisal." Comparative Studies in Society and History 38, No. 2 (April, 1996): 310-337.

Crowther, Edward R. "Holy Honor: Sacred and Secular in the Old South." Journal of Southern History 58, No. 4 (November, 1992): 619-636.

Toby L. Ditz. "Shipwrecked; or Masculinity Imperiled: Mercantile Representations of Failure and the Gendered Self in Eighteenth-Century Philadelphia." Journal of American History 81, No. 1 (June, 1994): 51-80.

Drescher, Seymour. "Servile Insurrection and John Brown's Body in Europe." Journal of American History 80, No. 2 (Sept. 1993): 499-524..

Etcheson, Nicole. "Manliness and the Political Culture of the Old Northwest, 1790-1860." Journal of the Early Republic 15 (Spring, 1995): 59-77.

Foner, Eric. "The Causes of the American Civil War: Recent Interpretations and New Directions." Civil War Hisotry 20 (September 1974): 194-214;

Geyl, Pieter. "The American Civil War and the Problem of Inevitability." New England Quarterly 24 (1951): 147-68.

Gorn, Elliott J. “'Good-Bye Boys, I Die a True American’: Homicide, Nativism, and WorkingClass Culture in Antebellum New York City" Journal of American History 74, No. 2 (Sept., 1987): 388-410. 
Griffin-Wolff, Cynthia. “'Masculinity' in Uncle Tom's Cabin.” American Quarterly 47, No. 4 (Dec., 1995): 595-618.

Hansen, Karen V. '“Helped Put in a Quilt:' Men's Work and Male Intimacy in Nineteenth Century New England." Gender and Society 3, No. 3 (September, 1989): 334-354.

Haralson, Eric L. "Mars in Petticoats: Longfellow and Sentimental Masculinity." Nineteenth Century Literature 51, No. 3 (December, 1996): 327-355..

Higginbotham, R Don. "The Martial Spirit in the Antebellum South: Some Further Speculations in a National Context." Journal of Southern History 58, No. 1 (Feb. 1992): 3-26.

Hoganson, Kristin. "Garrisonian Abolitionists and the Rhetoric of Gender, 1850-1860." American Quarterly 45, No. 4 (December, 1993): 558-595.

Horn, James. "Cavalier Culture? The Social Development of Colonial Virginia." William \& Mary Quarterly, 48 (1991): 239-240.

Lantz, Hernan R, et al. "Pre-Industrial Patterns in the Colonial Family in America: A Content Analysis of Colonial Magazines." American Sociological Review 33 (1968): 413-26.

Margadant, Jo Burr. "Gender, Vice, and the Political Imaginary in Post-Revolutionary France: Reinterpreting the Failure of the July Monarchy, 1830-1848." American Historical Review 104, No. 5 (December, 1999): 1461-1496.

Mathis, Robert Neil. "Preston Smith Brooks: The Man And His Image." South Carolina Historical Magazine 78 No. 1 (October 1978): 296-310.

Meriwhether, Robert L. ed. "Preston S. Brooks on the Caning of Charles Sumner." South Carolina Historical Magazine 52, No. 3 (January 1951): 1-21.

Morison, Samuel Eliot. "Faith of a Historian." American Historical Review 56 (January 1951): 261-275.

Owsley, Frank L. "Fundamental Cause of the Civil War: Egocentric Sectionalism." Journal of Southern History 7 (February 1941): 3-18.

Phillips, Ulrich B. "The Central Theme of Southern History" American Historical Review 34 (1928): 30-43.

Randall, J.G. "The Blundering Generation.” Mississippi Valley Historical Review 27 (June 1940): 4-16. 
Rose, Gregory S. "Hoosier Origins: The Nativity of Indiana's United States-Born Population in 1850." Indiana Magazine of History 81 (Sept. 1985): 202-32.

Schlesinger, Arthur M. Jr. "The Causes of the Civil War: A Note on Historical Sentimentalism." Partisan Review 16 (October 1949): 969-981.

. "The State Rights Fetish." New Viewpoints in American History (New York: 1922) 22-43.

Shorter, Edward. "Illegitimacy, Sexual Revolution, and Social Change in Modern Europe." Journal of Interdisciplinary History 2 (1971): 237-272.

Smith, Daniel S. "Parental Power and Marriage Patters-An Analysis of Historical Trends in Hingham, Massachusetts." Journal of Marriage and the Family 35 (1973): 419-28.

Sydnor, Charles. "The Southerner and the Laws." Journal of Southern History 6 (1940): 3-23.

Waldrep, Christopher. "The Making of Border Society: James McCready, The Great Revival, and the Prosecution of Profanity in Kentucky." The American Historical Review 99, No. 3 (Jun. 1994): 767-784.

Well, Robert V. "Family History and Demographic Transition." Journal of Southern History 9 (1975) 1-21.

. "Quaker Marriage Patterns in a Colonial Perspective." William and Mary Quarterly 3, 29 (1972): 415-42.

Williams, Jack Kenny. "The Code of Honor in Antebellum South Carolina" South Carolina Historical Magazine 56 (1953): 113-28.

\section{WEBSITES:}

The Brooks Historian, Home of the Brooks Genealogy Historical Archives and Reference Library. <http://brookshistorian.org/bbrooks/public.html.>

Descendants of Mexican War Veterans Website. Copyright, Descendants of Mexican War Veterans, 1996-2006. <http://www.dmwv.org/honroing/chucon3.htm).

Cardinal Stritch University Libraries Website. <http://library.stritch.edu.> 
Department of History, University of Virginia. U.S. History Survey Course Website: Unit 4: Sectional Conflicts During the 1850s" <http://www.iath.virginia.edu/ seminar/ unit4/brooks.html>

\section{UNPUBLISHED DISSERTATIONS:}

Shelton, William Allen. “The Young Jefferson Davis, 1808-1846.” Ph.D. diss. University of Kentucky. 1982.

\section{ALMANACS/ENCYCLOPEDIAS:}

Heidler, David s. and Jeanne T. Heidler, eds. Encyclopedia of the American Civil War a political social and military history. Santa Barbara, California: ABC-CLIO, 2000.

Massachusetts Historical Society. Proceedings of the Massachusetts Historical Society, Volumes 60, 61. Boston: The Society, 1927, 1928. 